Historic, Archive Document

Do not assume content reflects current scientific knowledge, policies, or practices. 



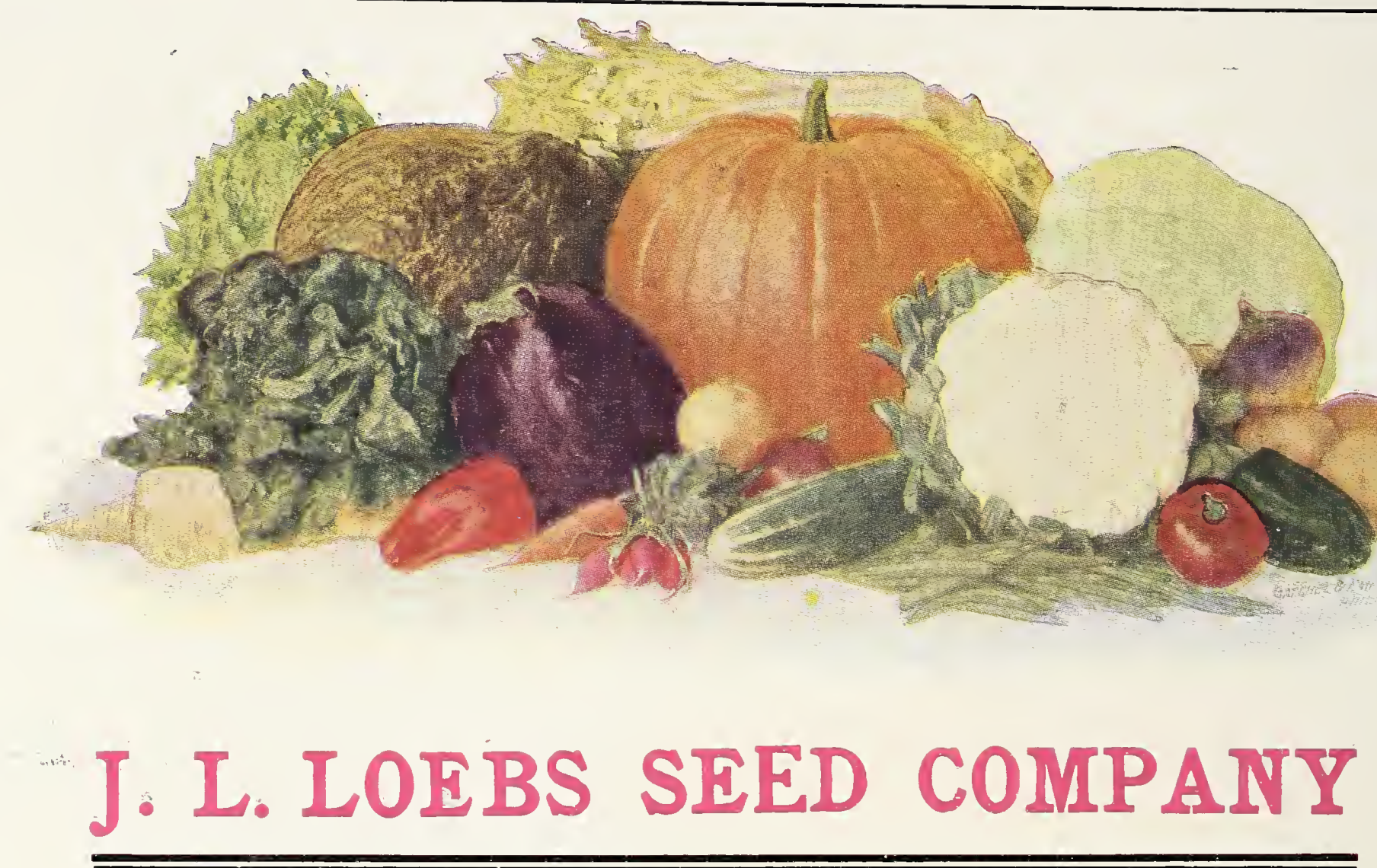

Our Hub City Brand Seeds are standard goods, extensively advertised and well and favorably known in all parts of our country. They are the highest grade of seeds that can possibly be produced and are therefore the best suited for first class, critical trade; they are in demand everywhere.

We do not claim to compete in prices with irresponsible growers and dealers, but we believe by carefully comparing our prices with those of other reliable concerns, you will find that you can buy from us to advantage. We have large stocks of all varieties on hand and have every facility to execute orders promptly, carefully and well.

\section{Are You An Old Friend?}

We again renew our pledge of honor to serve you as conscientiously and earnestly as in the past, to give you the same extra value for your purchase money that has gained your good will and high praise.

\section{Are You A New Friend?}

Then learn-today, now-all the advantages you secure through our high standards of quality, and our interested Personal Service. A single order will afford you practical proof.

And remember lastly our inflexible guarantee of your satisfaction or money returned. We are content only with your complete pleasure. Nothing which concerns you, no matter how small the purchase, is ever trivial or insignificant in our eyes.

We shall appreciate an order as an acknowledgment of your receipt of our catalog.

Please preserve this catalog for future reference. 
These prices effective danuary 1s1, 1920). Subject lo markel changes.

ALFALFA

Dakota No. 12-10 lbs., $\$(j .00 ; 50$ lbs., $\$ 28.00 ; 100$ lbs., $\$ 5 \% .000$

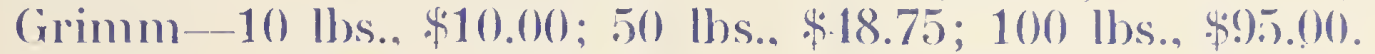

Montana Grown-10 lbs., $\$(0.00 ; .50$ lbs., $\$ 28.0(0 ; 100$ lbs., \$5.5.00(0.

BARILEY

Locb's Northern Grown 1 bu., $\$ 1.80 ; 10$ bu., $\$ 17.00$.

IVisconsin Podigreor-1 bu., \$2.0(); 10 bu., \$19.00.

BEANS

Soy or Soja $10 \mathrm{lbs.} \$ 1.5(0 ; 100) \mathrm{lbs} . \$ 12.0(0$.

BICGTWHEAT

Japanesc_-10 lbs., 75c; 100 lbs.. $\$(0.50$.

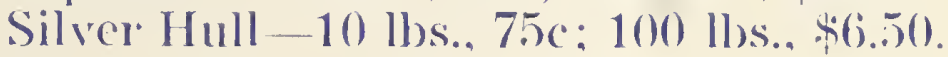

C.INE

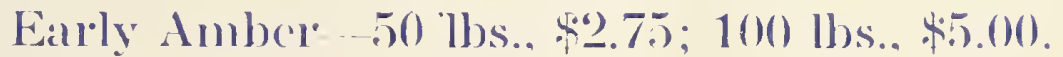

C.I.OVER

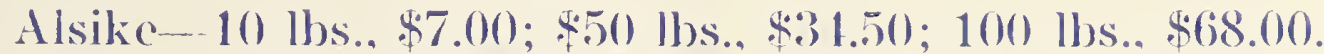

Mammolh Red - 10 lbs., \$7.00); 50 lbs., \$34.50; 100 lbs., $\$ 68.00$.

Medium--10 lbs., \$7.00; 50 lbs.. \$\$34.50; 100 lbs., $\$ 68.00$.

White Blossom Sweet-10 lbs., \$4.50; 50 lbs., \$21.0(); 100 lbs., \$40.00.

White Dutch--1 lb., 80c; $10 \mathrm{lbs} ., \$ 7.50 ; 50 \mathrm{lbs} ., \$ 37.00 ; 100 \mathrm{lbs} ., \$ 72.00$.

Yellow Plossom-10 lbs., \$1.25; 50 lbs., $\$ 20.00 ; 100$ lbs., $\$ 38.00$.

C.ORN

Kallir-100 lbs.. \$5.00.

Milo Maize -50 lbs., \$2.75; 1000 Hbs., \$5.0(0.

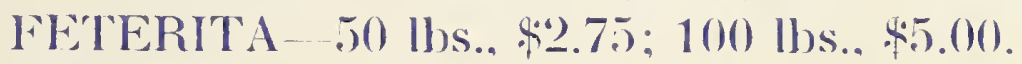

(IRASSES

Brome Grass--10 lbs., $\$ 4.00 ; 50$ lbs., $\$ 18.00 ; 100$ lbs., $\$ 35.00$.

Kientucky Bluc-1 lb.. $15 \mathrm{c} ; 10$ lbs., \$1.00; 50 lbs.. $\$ 19.50 ; 100 \mathrm{lbs.}$ $\$ 38.00$.

Meadow Fescue-10 lhs.. $\$ 3.80 ; 50$ lbs., $\$ 18.00 ; 100$ lbs., $\$ 35.00$.

Mixture for High Land-10 lbs., $\$ 4.50 ; 50$ lbs., $\$ 18.00 ; 100 \mathrm{lbs} ., \$ 10.00$.

Mixture for Hog Pasturc-10 lbs., $\$ 4.5(0 ; 50$ lbs., $\$ 20.50 ; 100$ lbs., $\$ 40$.

Mixture lor L.ow Damp Soil-10 lbs.. \$4.25; 50 lbs.. \$20; 100 lbs.. \$\$39.

Orchard Grass -10 lbs., $\$ 3.75$; 50 lbs., $\$ 17.50 ; 100$ lbs., $\$ 34.00$.

Red Top-10 Ibs., \$3.00; 50 (lbs.. $\$ 14.50 ; 100$ lbs., $\$ 28.00$.

Slender Wheal Crass- 10 lbs., \$2.90; 50 lbs. \$14.00; 100 lbs.. \$27.00.

Sudan-50 lbs., \$0.00: 100 lbs., \$17.00.

Timothy-10 lbs.. \$1.75; $50 \mathrm{lbs.} \$ 8.00 ; 100 \mathrm{Hbs..} \$ 15.0()$.

MIILI.ET

Broom Coln -1 bu., \$2.25; 100 lbs., \$1.25.

Fally Fortune 1 bu., $\$ 2.25 ; 10($ lbs.. $\$+25$.

(iolden (Northern grown) - 1 bu.. \$2.25; 100 lbs., \$1.2.).

Golden (Soulliern grown) - 1 bu.. \$2.50; $100 \mathrm{lbs.} \$ 4.75$.

Japanese-1 bu. (50 lbs.), \$3.75; 100 lbs., $\$ 7.00$.

Siberian (Northern grown) - 1 bu.. \$2.25; 100 lbs.. \$1.2.).

() $\backslash \mathrm{TS}$

Sibcrian (Soulhern girown) - 1 bu.. \$2.50; $100 \mathrm{lbs.,} \$ 1.7 .5$.

Kherson or Sixly Day 1 bu., \$1.35; 10 bu.. \$13.(0).

PF.AS

Swerlish Solece 1 bu.. \$1.35; 10 bu.. \$13.00.

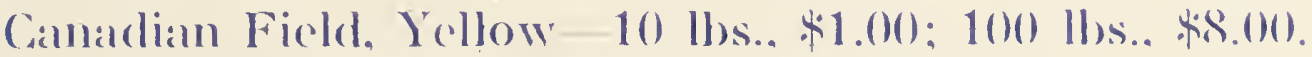

Cow Poas 10 Ibs. \$1.20; 100 lbs.. \$10.00.

RiAPF

D)warl Fssex 10 Hos. \$1.60; 100 lbs.. \$15.00.

SPFLTS or EMMER 1 bu.. \$1.70; 10 bu.. \$16.00).

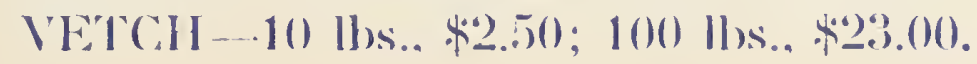



Name

Pest Office

State

R. F. D. No.

Bor

Street Addreas

\section{J. L. LOEBS SEED CO.}

\section{ABERDEEN}

402-404 South First Street

SOUTH DAKOTA 


\section{READ BEFORE SEALING}

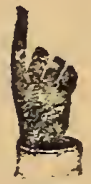

Hundreds of orders are delayed because the sender fails to give his name and address. Be sure to write your name and address plainly. 


\section{LOEBS SEEDS}

\section{GENERAL LIST OF HIGH GRADE VEGETABLE SEEDS SELECTED WITH ALL POSSIBLE CARE}

We have made an extra effort in behalf of our many customers this season and have made a contract with one of the very best seed growers in the country for our vegetable and flower seeds this coming year. We put up our own packets and can assure the public that none but the very best obtainable seeds are contained therein.

\section{Artichoke}

Seeds are sown in April, in rows 2 feet apart, covered $1 / 4$ inch deep. Seedlings should be thinned out to stand 6 to 8 inches apart in the row and cultivated like any other vegetable. Grown from seeds, sown outdoors, the plants will not bear globes until the following years.

Large Green Globe.-A member of the thistle family whose edible flowerheads make a most delicious dish either eaten raw or as a salad. Pkg., 10e; oz., 50e; $1 / 4$ 1b., \$1.25, postpaid.

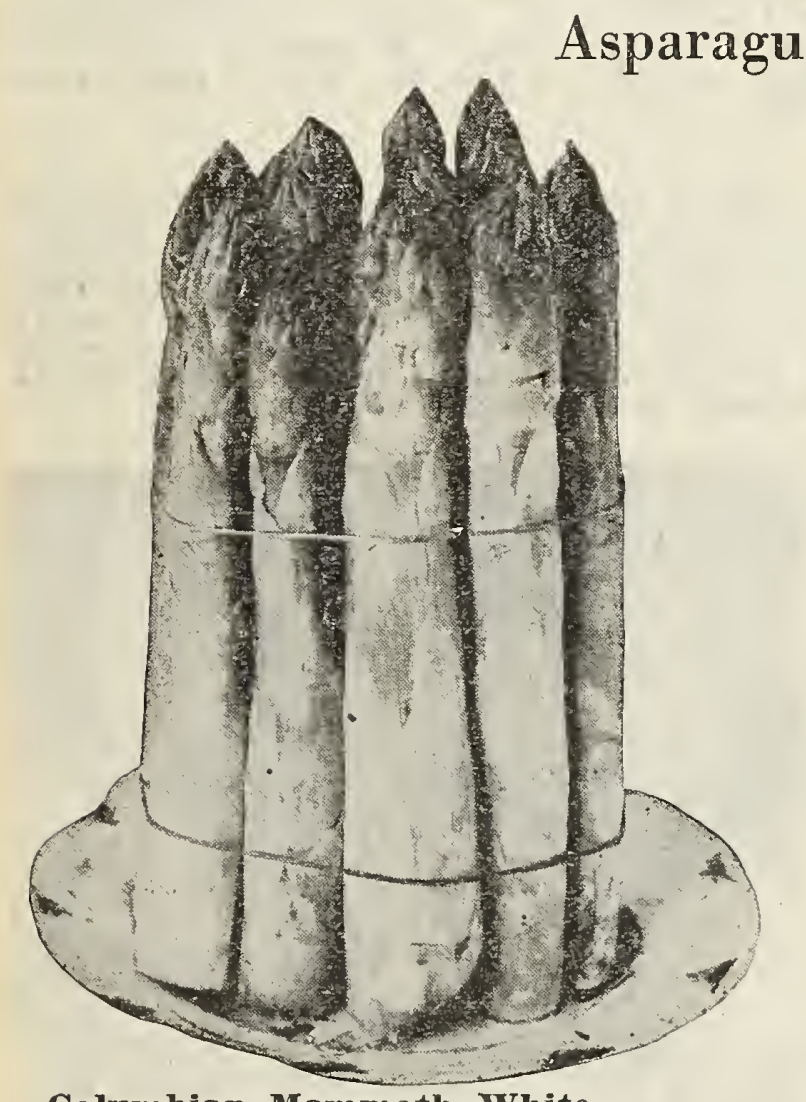

Columbian Mammoth White Asparagus.

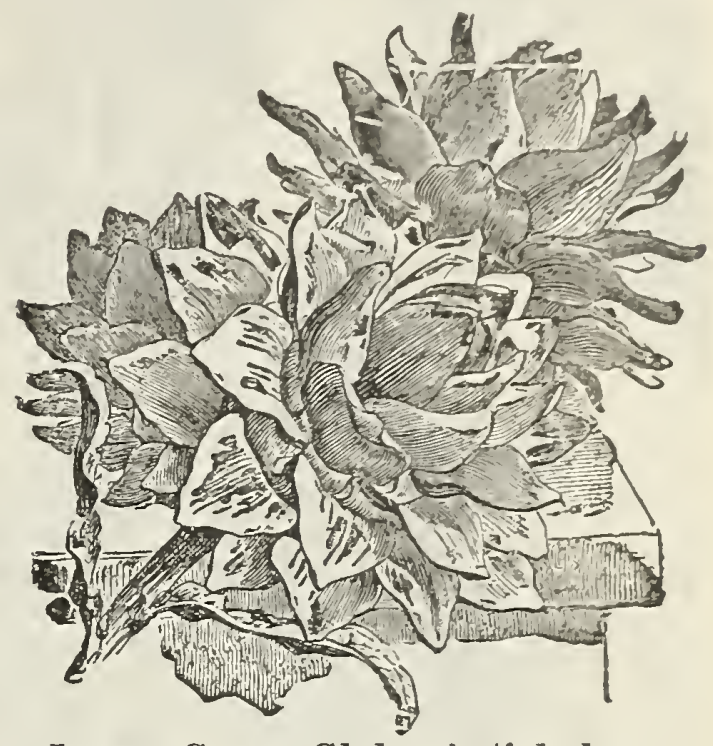

Large Green Globe Artichoke.

Seeds are sown as early in the spring as garden can be made, in rows $2 \frac{1 / 2}{2}$ to 3 feet apart, dropping 1 seed to every $1 / 2$ inch and covering them about $1 / 2$ inch. One ounce to 100 feet row. Seedlings generally appear within 3 weeks. When 6 inches high they should be thinned out to stand 6 inches apart in the row.

Columbian Mammoth White. - This variety cannot be surpassed for tenderness. The shoots remain white as long as they are fit for use without any artificial blanching. Pkg., 5c; oz., 10c; $1 / 4$ 1b., 25e; 1b., 85c., postpaid.

Conover's C o 1 o s s a 1.- -Very large variety of excellent quality. Pkg., 5c; $9 z ., 10 c ; 1 / 4$ lb., 25c; ib., T0e, postpaid.

\section{Brussels Sprouts}

A vegetable resembling the cabbage, for winter use.

Improved Dwarf.-Very prom ductive, growing $1 \frac{1}{2}$ feet high. Pkg., 5e; oz., 15e; $1 / 4$ 1b., 50c; $1 \mathrm{~b}$., $\$ 1.00$, postpaid.

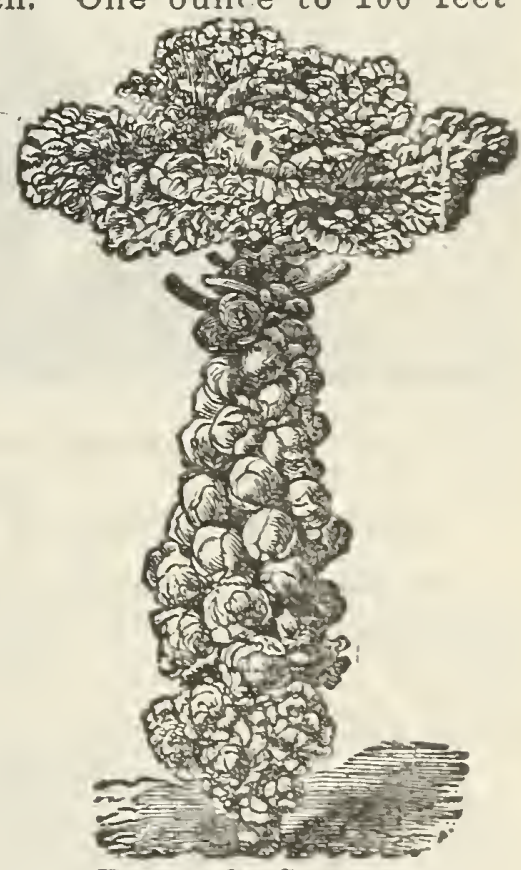

Brussels Sprouts.

\section{Vegetable Plants}

WE GROW GREAT QUANTITIES OF CABBAGE, CAULIFLOWER, CELERY A ND TOMATO PLANTS

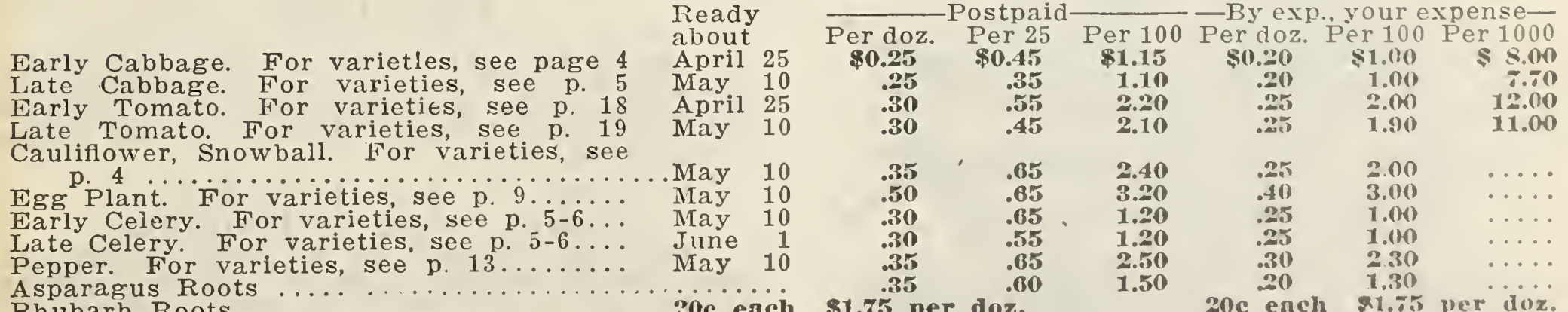




\section{BEANS}

At the following prices on Beans-packets and quarter pounds and pounds are sent prepaid; all larger quantities are shipped at purchasers expense. If wanted by parcel post, add postage.

CULTURE.-Beans are very sensitive to the cold and should not be planted before the middle of May. Place furrows 2 feet apart, about 2 inches deep, and drop seeds 4 inches apart in the rows. One pound of seed to 100-foot row. Weeding, hoeing and hilling are the three main needs of beans.

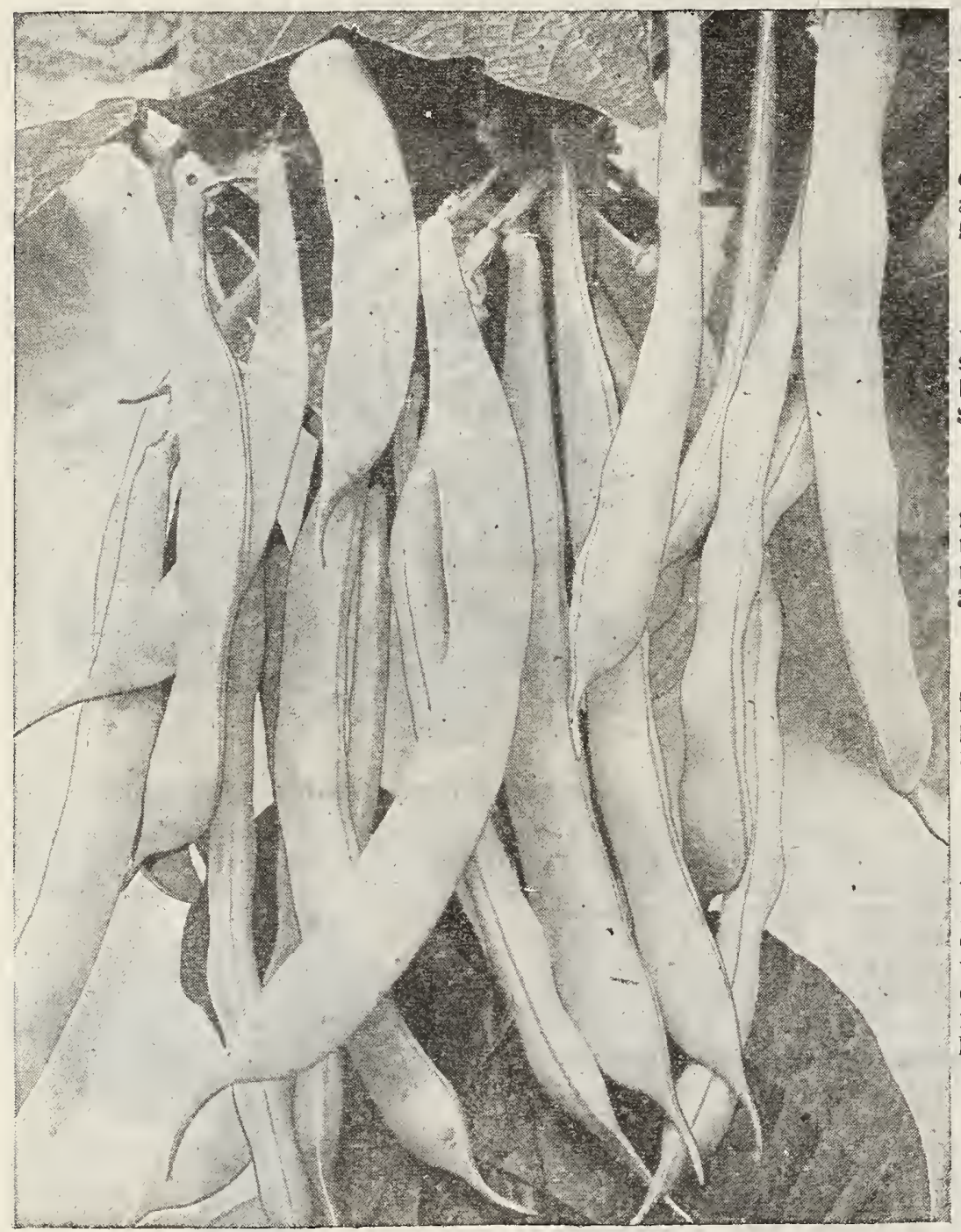

Improved Golden Wax.

\section{Dwarf Green Podded Beans}

Burpee's Stringless Green Pod.-After a quarter century, this bean is still the leading round podder green variety. Ready in 60 days. Of wide adaptability to different soils, seasons and climates. It is entirely stringless and remains seasons and climates. It is entirely stringless and remains $1 / 4$ lb., 10c; 1 b., 35c; 5 1bs., \$1.50; 10 lbs., \$2.75.

Long Yellow Six Weelks.-This is a truly pedigreed sort of bean that will bear its handsome, 7 -inch pods regularly within 60 days after seeds were sown and will continue to bear for 6 weeks thereafter. Plkg., 5e; 1/4 1b., 10c; lb., 35c; 5 lbs., \$1.50; 10 lbs., \$2.75.

Improved Red Valentine.--One of the earliest roundpodded green beans. These seemingly enjoy greater favor with the broad masses of planters than the flat-podded with the broad masses of planters pecause of their superior appearance and greater kinds because of their superior appearance and greater \$2.75.

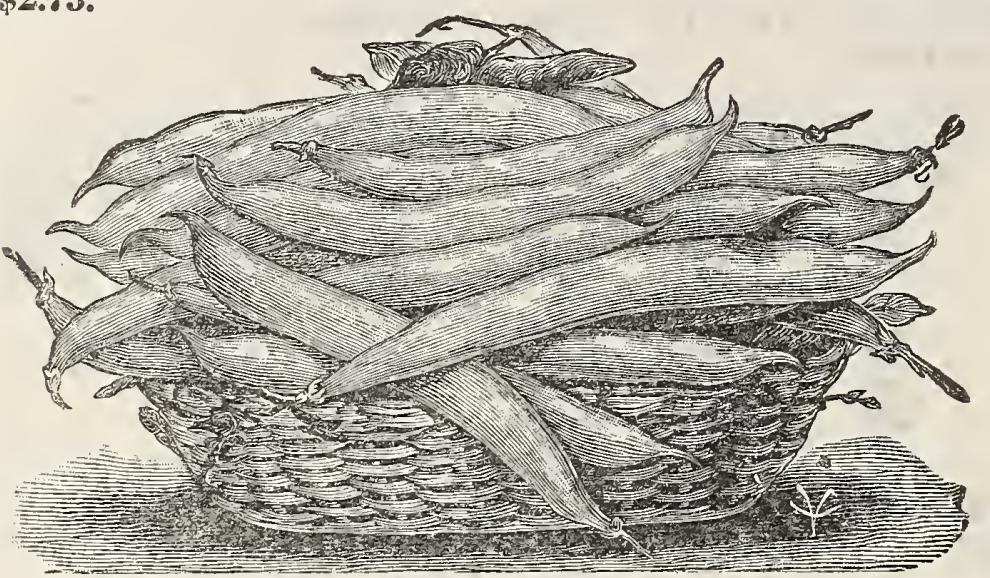

Davis Kidney wax.
Wardwell's Kidney Wax.-Especially desirable market gardeners and home use on account of curing a little later than the Golden wax. Plkg. 5e; $1 / 4$ lb., 10c; 1b., 35c; 5 lbs., \$1.50; 10 lbs., $\$ 2.75$.

Refugee Wax. A bush bean growing about 15 nches high with round, slender, golden-colored pods about 5 inches long. Extremely solid and meaty. Pkg., 5e; 1/4 lb., 10e; 1b., 35e; 5 lbs., \$1.50; 0 lbs., \$2.75.

Davis Kidney Wax.-We personally recommend this as one of the very best beans on the market. is especially desirable as a canning bean on acount of the whiteness of the bean, also the pod of this bean is that it will thrive where other beans fail. Why not send us a trial order? Pkg., 5e; 1/4 b., 10c; 1b., 35e; 5 lbs., \$1.50; 10 1bs., \$2.75.

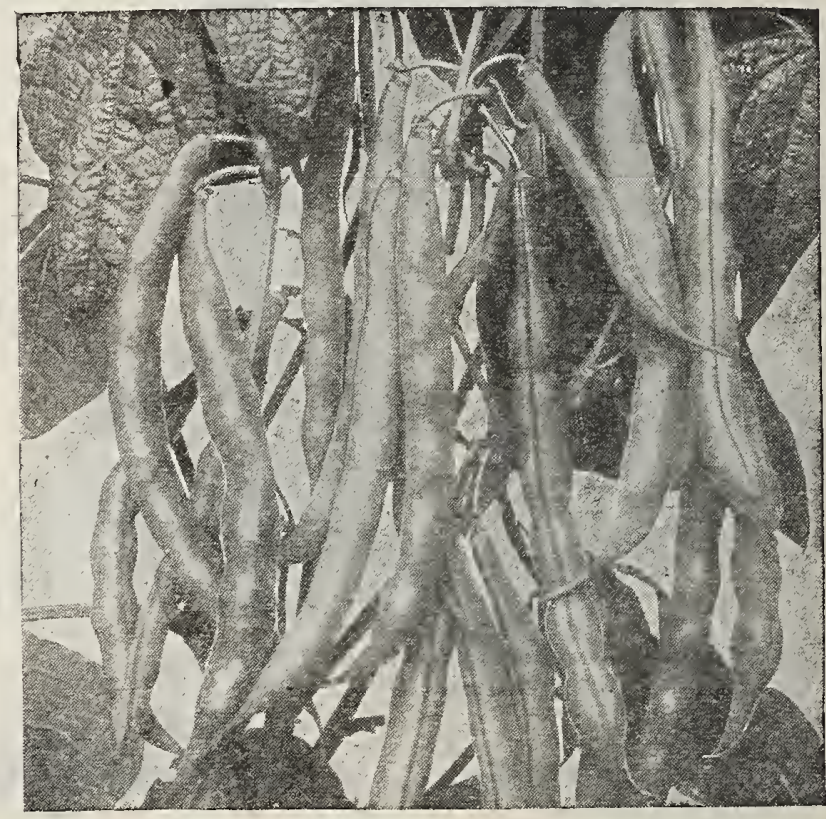

Burpee's Stringless Green Pod Beans.

\section{Field Beans}

Choice Navy.-Our Navy beans are absolutely clean as we buy none but hand-picked seed. Small, clean, as we buy none but hand-picked very desirable white oval beans with green pod. Very desirable $\$ 1.50$; 10 10.s., \$2.75.

\section{Beans-Pole or Running}

Kentucky Wonder.- Is the most popular and most prolific, considering size of pods and number of pods per plant. Pods 7 to 9 inches long and exceptionally stringless when young. Pkg., 5e; $1 / 4$ lb., 10e; 1b., 35e; 5 lbs. \$1.50; 10 lbs., \$2.75. 


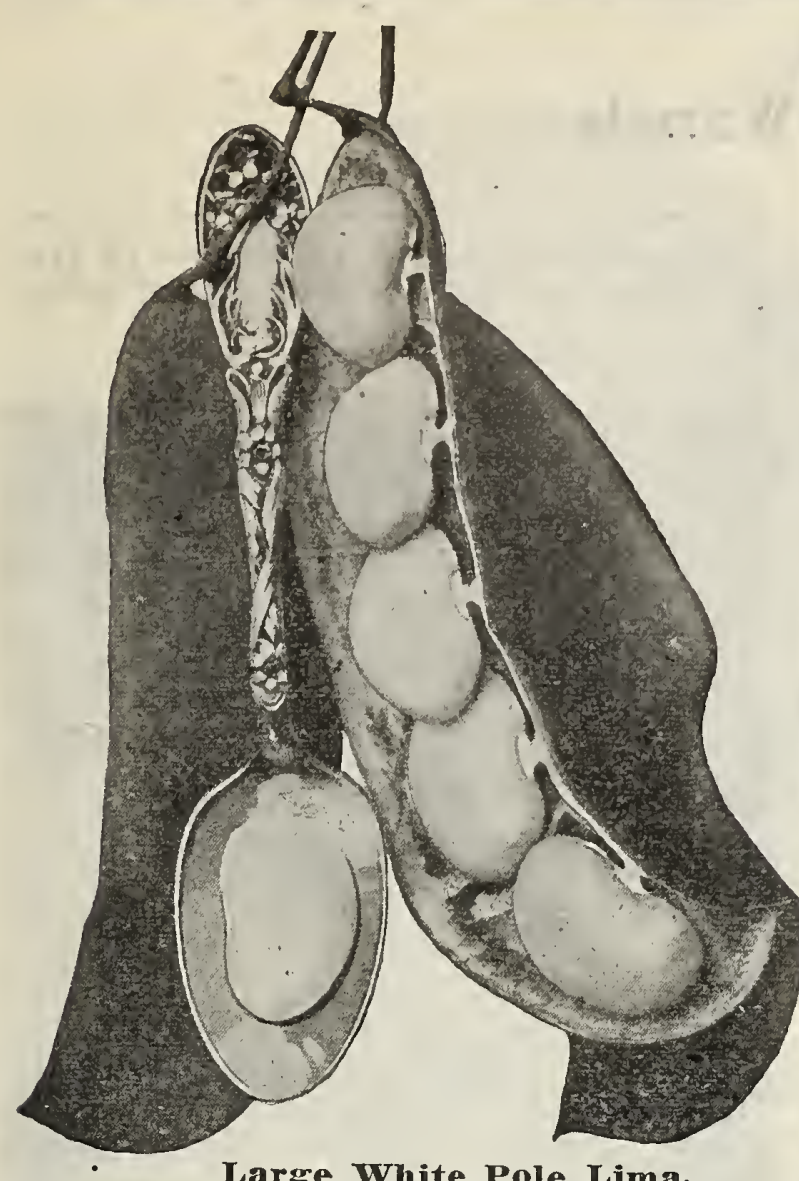

Large White Pole Lima.

Lazy Wife--Very prolific, bearing great clusters of medium-sized pods that are perfectly stringless while young. The dry bean is about twice the size of the Navy, this making it an elegant variety for winter use. Pkg., 5e; 1/4 lb., 15e; lb., 45c; 5 lbs.s \$2.00; 10 lbs., \$3.75.

Large White Pole Lima.-Particular care must be taken in planting these seeds "eye down." Half the failures in not getting a good stand of young plants are due to the disregard of this important point. This variety is a very heavy yielder with pods $51 / 2$ inches long. No garden is complete without a few Lima beans. Pkg., 5e; 1/4 lb., 15c; lb., 45e; 5 lbs., \$2.00; 10 lbs., $\$ 3.75$.

New Wonder Bush Lima.-Bush growing about 20 inches high, bearing from 50 to 150 pods. Pods closer to the ground than most varieties of bean. Very heavy yielder. Pkg., 5e; 1/4 Ib., 15c; 1b., 45e; 5 lbs., \$2.00; 10 lbs., \$3.75.

\section{GARDEN"BEETS--SELECTED STOCK}

CULTURE.-Sow the seeds early in the spring, in rows $1 / 2$ to 1 inch deep, allowing 18 inches to 2 feet between the rows. After covering walk over the rows to firmiy press. the soil in contact with the seeds. Three ounces will provide all the beets required by the average family.

Colipse.-This is one of the oldest, but also one of the most dependable sorts; top shaped, red and white grained. Very early. Pkg., 5e; oz., 10e; 1/4 Ib., 35e: 1b., 90c, postpaid.

Crimson Globe.-Medium-sized dark red smooth roots, nearly globe shaped. Fine grained flesh, free from woodiness. Pkg., 5c; oz., 10c; 1/4 1b., 35e; Ib., 90c, postpaid.

Crosby's Egyptian.-We personally recommend this variety of beet. It is considered the greatest market variety in the country. The tops are small, roots very uniform in size, turnip shaped and deep red color. They are ready for market 'n about 40 days. Do not fail to include a few of these beets in your order. Pkg., 5c; oz., 10e; 1/4 lb., 35c; 1b., in your order. Pkg., 5e; oz., 10e; 1/4 Ib., 35c; 1b.,

Harly Blood Turnip.-This variety is one of the leading varieties for canning. The roots are dark red globe shaped, very tender and sweet. For winter storage it is advisable to let the roots grow somewhat larger than 2 inches. Pkg., 5e; ox., 10e; 1/4 1b., 35e; 1.,., 90c, postpaid.

\section{Swiss Chard or Spinach Beet}

Grows 2 to $2 \frac{1}{2}$ feet high, producing very broad stalks similar to rhubarb. These are used for greens the same as spinach and will yield a continuous crop from June to winter. Pks.. 5e; oz.. 10c; $1 / 4$ 1b., 35e; 1b., 90e. postuatid

Try our Crimson Giant Radish. Sce description on page 15.

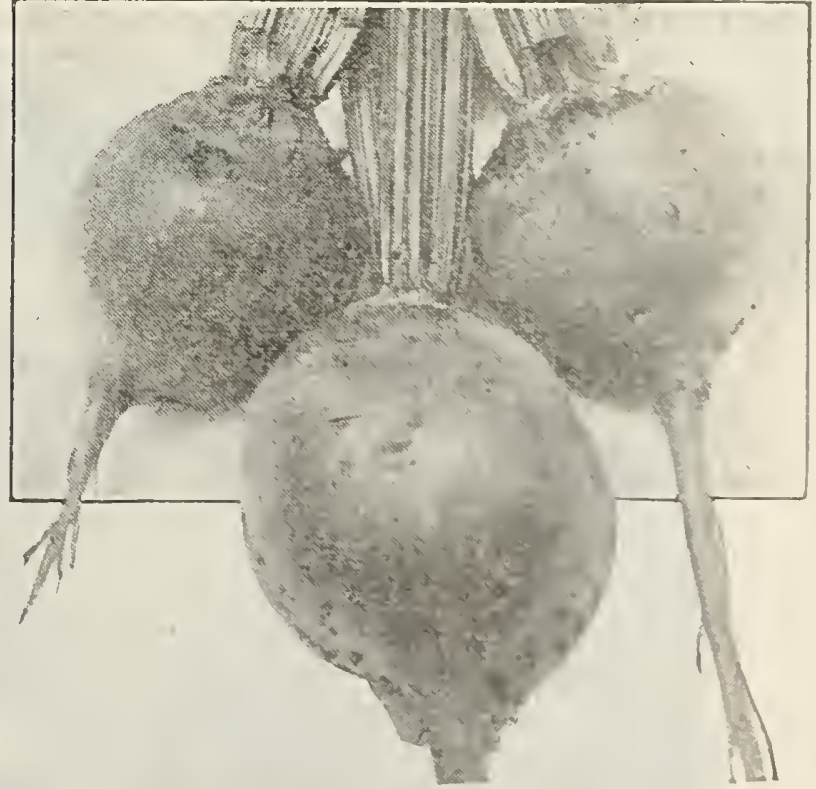

Crimson Globe Beets. 


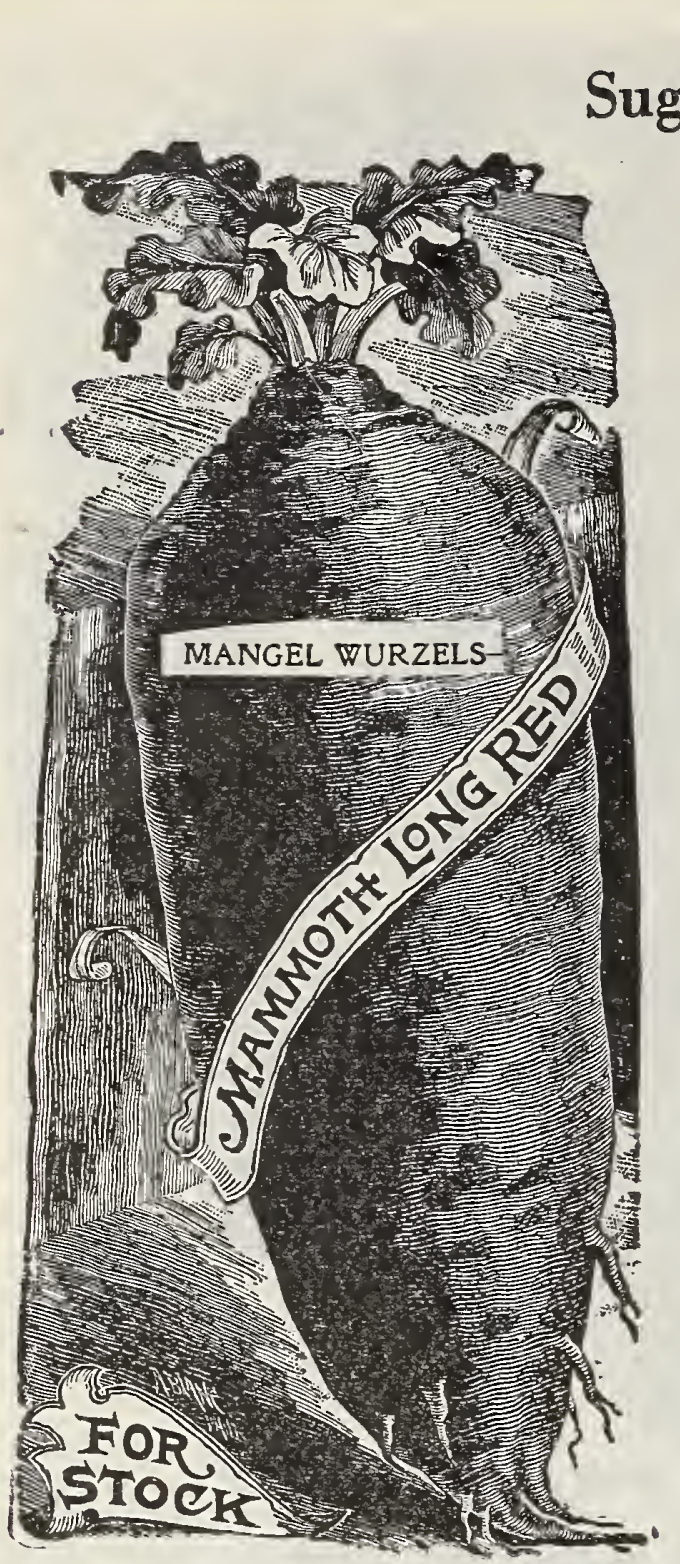

BEETS-Continued.

Sugar Beets and Mangel Wurzels

M a m moth
Long Red. - This

variety is a very

heavy yield er,

of $t$ e n producing

over 20 tons per

white tinged with

rose. It is a great

rose. It is a great

favorite with the

a great milk pro-

ducer. Pkg., 5e:

oz., 10c; $1 / 4$ lb., 35c

lb., 80c, postpaid.

Golden Tank-

ard. - Half long

roots deep orange

color zoned with

white. Yields a

very easily har-

vested. Pkg., 5e;

OZ., 10c; $1 / 4$ lb., 35c; 1b., 80e, postpaid. ben.-This sugar beet is the most popular be e $t$ at the present time. It yields an average of 16 tons to the a cre with about $13 \%$ sugar, the sug a r beet pulp and alfalfa make the very best feed for cat best feed for cattle. Pkg., 5e; oz. lb., \$1.00, p o s t paid.

\section{We want all of our customers to try our Crimson Griant Radishes. See page 15.}

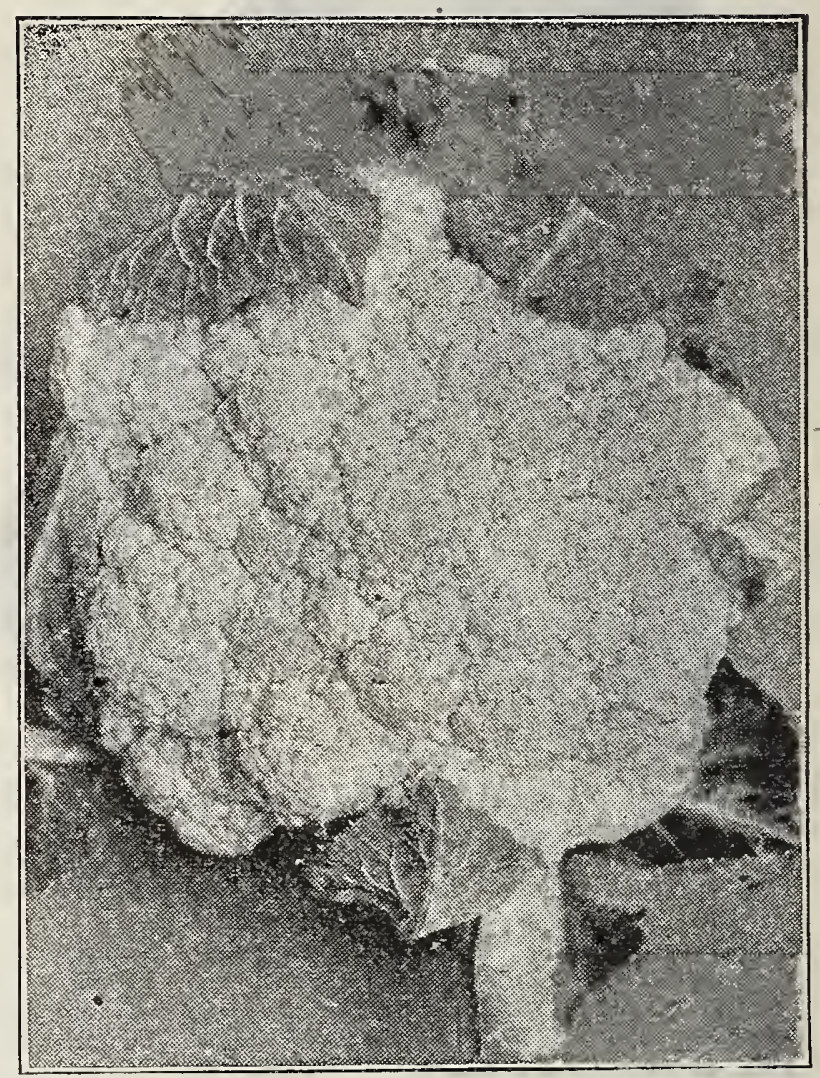

Cauliflower

\section{Seeds resemble the cabbage and}

them, plants transplanted in a simllar manner. Clean and thorough cultivation is absolutely essential to success with this vegetable. Hoe close to the plants. When heads begin to form draw some of the leaves across to prevent the sun from discoloring or scorching them.

Early Dwarf Erfurt.-For a good solid head this variety has no superior. If thoroughly cultivated it will give the highest yield and be ready for market earlier than any other variety. Pkg., 15e; $1 / 4$ oz., 65e, postpuid.
Drought Resisting.-This variety produces wilite compact heads with very heavy leaves which protect the heads from the hot sun. It will con1/4 oz., 65c, postpaid.

Larly Snowball.-Undoubtedly the king of all Cauliflowers. The snow white heads measure from 6 to 8 inches in diameter. In quality this variety is unsurpassed, being crisp, tender and sweet. Can also be used as a late winter crop. Pkg., 15c; $1 / 4$ oz., zoc, postpaid.

\section{CABBAGE}

CULTURE.-Sown induors or in the garden they should be sown rather thinly and be covered about $1 / 4$ to $1 / 2$ inch deep. For extra early crops seeds are sown under glass, in either hotbed or cold frame, in rows 4 inches apart. Plenty of ventilation is needed at all times to prevent plants from becoming spindly. Cabbages must be transplanted in order to do well.

Early Jersey Wakefield.-Forms head 5 inches in diameter by 8 inches long within 100 days from date seed is sown. Heads compact and solid with small leaves. Pkg., 10e; oz., 50e; 1/41b., \$1.75; 1b., $\$ \mathbf{\$ 5 . 0 0}$, postpaid.

Early Winningstadt.-Large conical shaped heads very hard which makes it almost impossible for worms to bother. This is one of the most reliable varieties to plant for winter use. I'kg., 10c; oz., 50e; 1/4 1b., \$1.75; lb., \$5.00, postpaid.

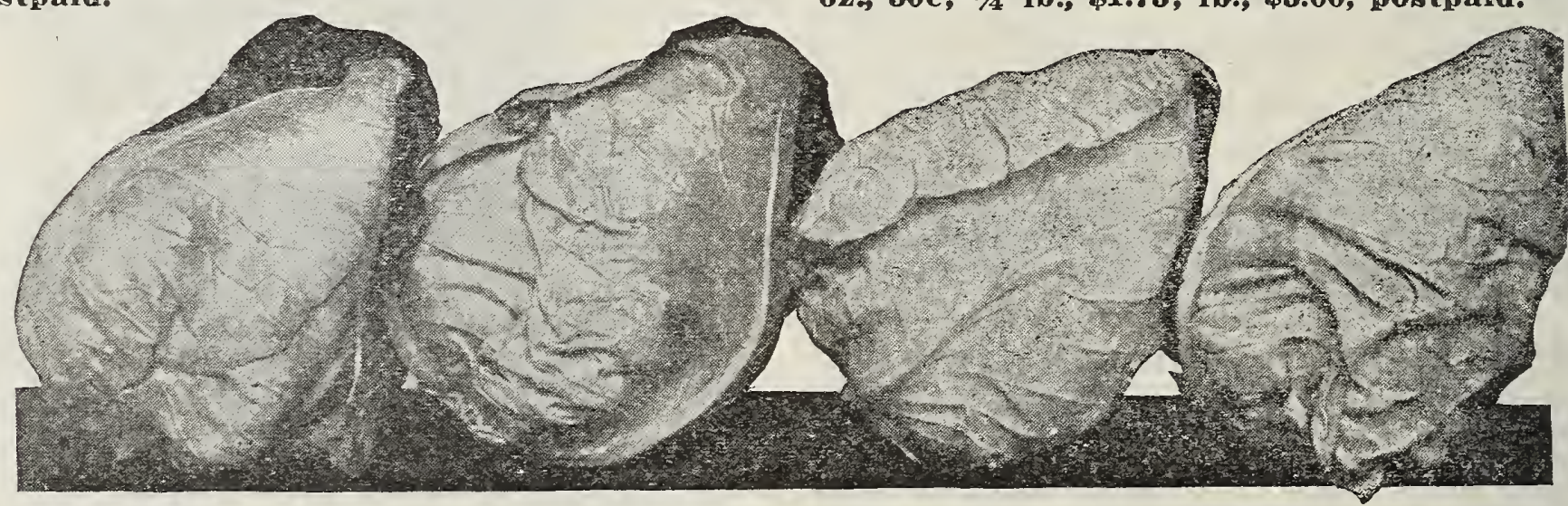

Early Jersey Wakefield. 


\section{CABBAGE-Continued.}

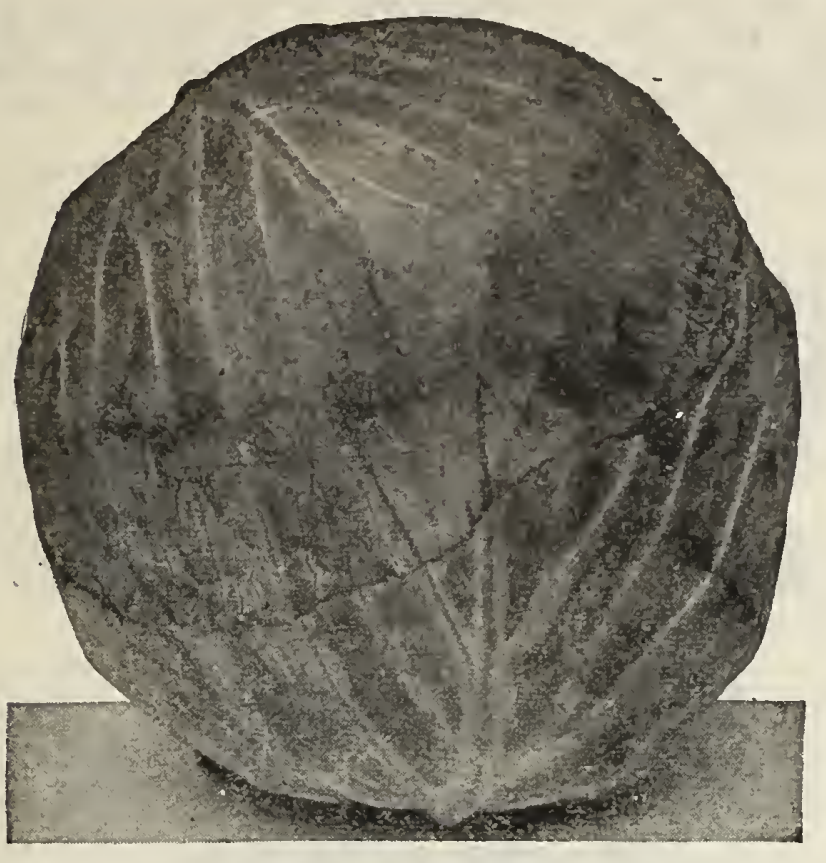

Copenhagen Market.

\section{Celery or Chinese Cabbage}

Pe Tsai.-A most delicious variety of cabbage used widely as a salad vegetable. The heads are very tender resembling white Lettuce. The leaves blanch such a creamy white that it makes a very palatable dish cooked like asparagus. Pkg., 10c; oz., 50c; 1/4 1b., \$1.75; 1b., $\$ 6.00$, postpaid.

\section{Cress}

Culture.-Sow very thinly in rows, a foot apart cover lightly and use as fast as it becomes 6 inches tall. Seeds are best started in pots, early in April and seedlings transplanted in Mray.

True Water Cress.-Forms very fleshy stems and leaves but requires very moist soil to do well. If grown on the banks of a stream of water it will thrive year after year. Pkg., 5c; oz., 15c, postpaid.

Curled or Pepper Grass.-This is one of the most appetizing of all Spring salads and it really grows as fast as grass, making a very rapid growth in any garden soil. It grows so rapidly that the home gardener seldom has a chance to use it all before it goes to seed. Pkg., 5e; oz., 15c, postpaid.

\section{Chives}

Hardy perennial plants belonging to the Onion family. The tops-are used to impart the mild onion flavor in soups, sausage, salads, etc. Pkg., onion flavor in soups,
Early Summer.-Heads are large round and very compact. A Lew days later than the Jersey Wakefield. Heads often weigh 10 to 12 pounds Danish IBall Head.-One of the very begt of winter cabbages. This variety shows a distinct preference for heavy clay soil and does not do as well on thin land. Heads are medium size, solld and deep. Pkg., 10c; 0\%., 50c; 1/4 11)., \$1.80; 1b., \$6.00, postpaid.

Surelıead.-This variety is especially desirable because of its certainty to head even tho conditions are not favorable. Iakes a very solid large head ripening late. Pkg., 10c; 0z.,50c; 1/4lb., $\$ 1.75$ Ib., \$5.00, postpaid.

Ali Sensons.-Heads very large, almost round, very hard and solid and flat on top. This variety will remain longer in the field without burstin than any other cabbage. True to its name "Al tor winter as for summer use. Pkg.. 10c; oz., 50c; 1/4 1b., \$1.75; 1b., \$5.00, mer use.

Copenhagen Market. - We consider this the very best cabbage on the market. It has large round heads and is very short stemmed, the heads almost resting on the ground. It will mature fully as early as the Wakefield but yields far more to the acre. If you once try this cabbage you will never have another garden without it. Pkg., 10c; oz., 80c; 1/4 lb., $\$ 3.00$; 1b., $\$ 10.00$, postpaid.

Late Flat Dutch.-Perhaps the most widely known of all cabbages because it thrives most anywhere. The head is large broad and flat and is an excellent keeper. Pkg., 10c; oz., 50c; 1/4 lb., \$1.75: lb., \$5.00, postpaid.

Rock Red.-The leading characteristic of this type is the deep, purplish red coior of it's foliage. This color extends thru the entire head although the ribs a wite with a reddish tinge. It makes a very delicious slaw being dish tinge. It makes a very delicious slaw being both attractive in appearance and postpaid.

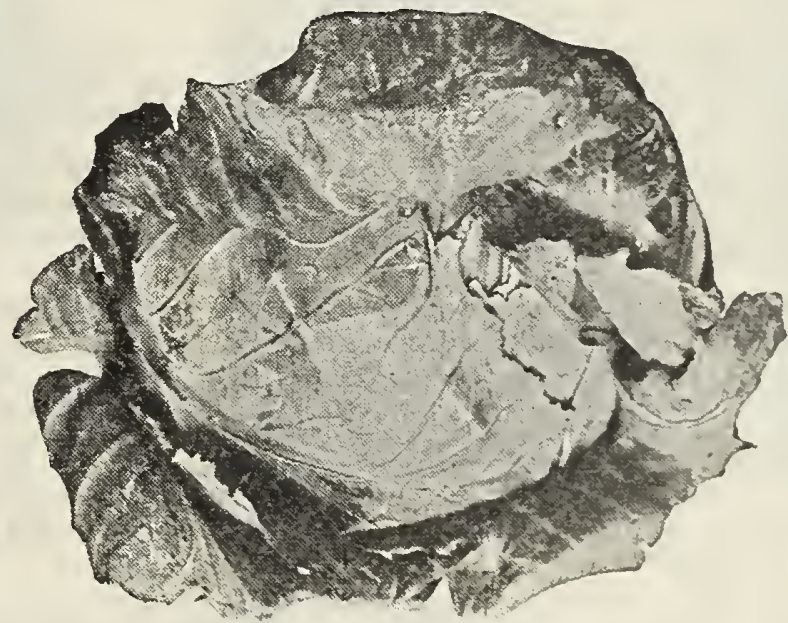

Rock Red Cabbage.

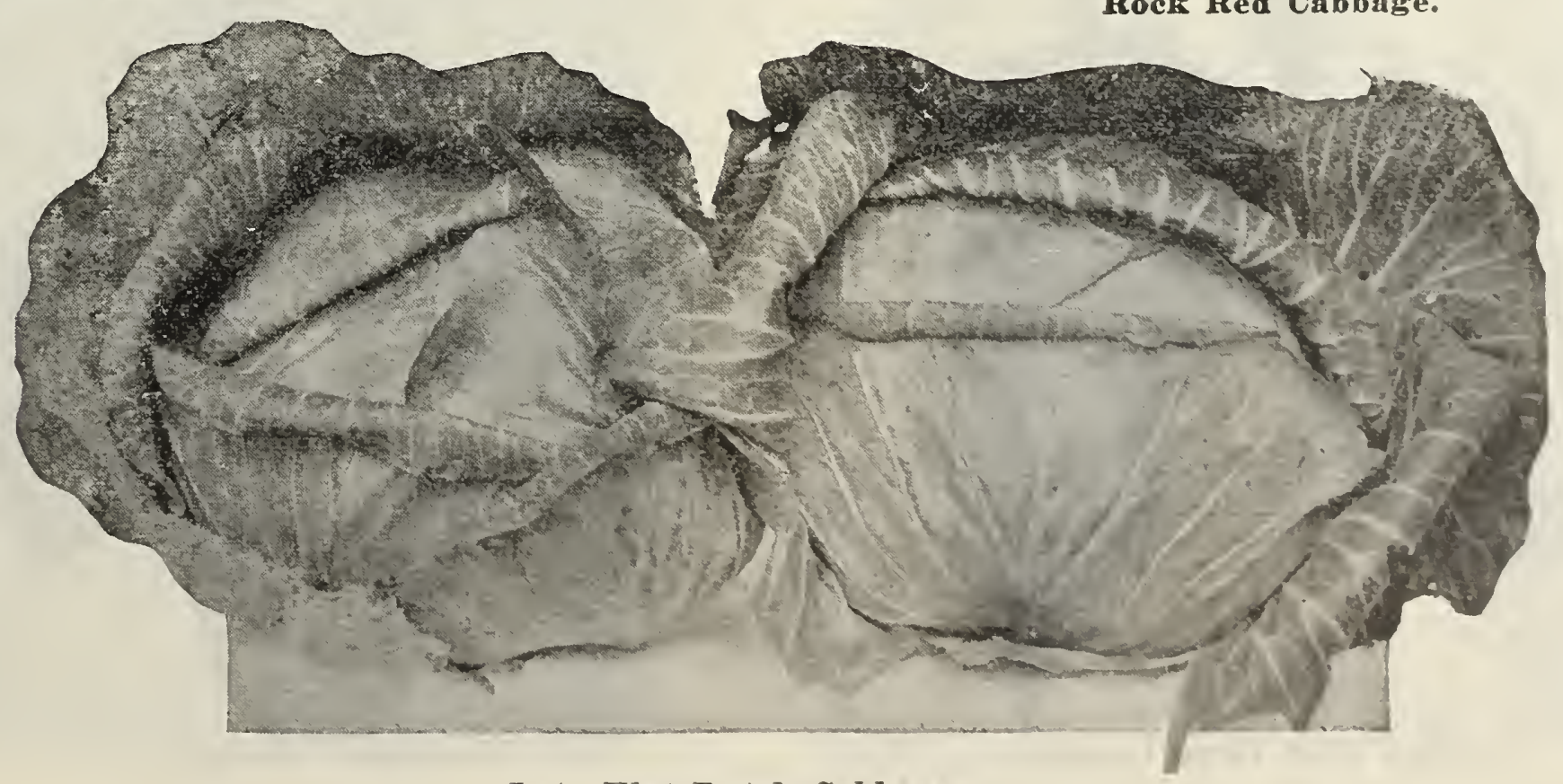

Late Flat Duteh Cabbage. 


\section{CELERY}

All sorts of celery prefer a rich, deep soil. Sow very thinly in furrows about 3 inches apart, cover lightly and press soil in firm contact with the seeds with the flat side of a board. Cover surface of bed with muslin or paper and water until the soil has become thoroughly saturated. Celery seed is very slow to germinate and should be kept in a steady temperature, like an ordinary living room. As soon as seedlings appear, they must be kept cooler to prevent a spindly growth.

White Plume.-This is easily the quickest maturing sort in cultivation, becoming ready for use in August from seed sown in March. Very popular on account of its ease of culture. Self blanching. Plkg., 5e; oz., 25e; $1 / 4$ lb., 75e; 1 b., $\$ 2.60$, postpaid.

Golden Self-Blanching.-This is a French celery of selected stock which accounts for its being so much higher in price than other varieties. It is far superior in quality to the White Plume and keeps well until Christmas. It really is not self blanching. The name, "Self Blanching," rather refers to the ease with which that work is accomplished. The most nearly stringless of all varieties. Pkg., 15e; oz.o $\$ 1.15$, postpaid.

Celeriac or Turnip Rooted Celery.-A form of Celery cultivated for its fleshy roots which, prepared as a salad or served hot with cream sauce, form dishes of rare flavor. These roots are excellent for winter use for flavoring soups, etc. Pkg., 5e; oz., 20c; $1 / 4$ 1b., 50c; 1b., \$2.10, postpaid.

\section{Chervil}

Used for flavoring soups, salads and for garnishing. Grows to a height of 18 inches and is very hardy. Pkg., 10e; oz., 20c; 1/4 1b., 50e, postpaid.

\section{Collards}

A form of vegetable resembling the cabbage. It has loose clusters of leaves which are used for greens. Cultivate the same as Cabbage. One ounce greens. Cultivate
to 2,000 plants.

Georgia.-The most widely known variety. Leaves tinged with a purplish red. Pkg., 10e; oz. 20c, postpaid.

\section{Carrots}

Any soil will grow good carrots Seeds should be sown as early as the soil can be dug and raked in rows 18 inches apart. Cover them lightly about $1 / 2$ inch in light soil and less in heavy clay. It generally takes from 10 to 14 days for seedlings to appear. Frequent and thorough hoeing is essential to growing good carrots. One ource will sow about 200 -foot row.

Danvers, Half Long.-Does well in any kind of soil and is astrong grower under all climatic conditions and always of good color and flavor. Seeds should be sown from early spring up to the middle of June, as the roots require 120 days to reach full size. Well developed roots average 6 to 8 inches long by two to two and a half in diameter, tapering to a blunt point. Pkg., 5e; oz., 10c; 1/4 lb., 35e; lb. $\$ 1.00$, postpaid.

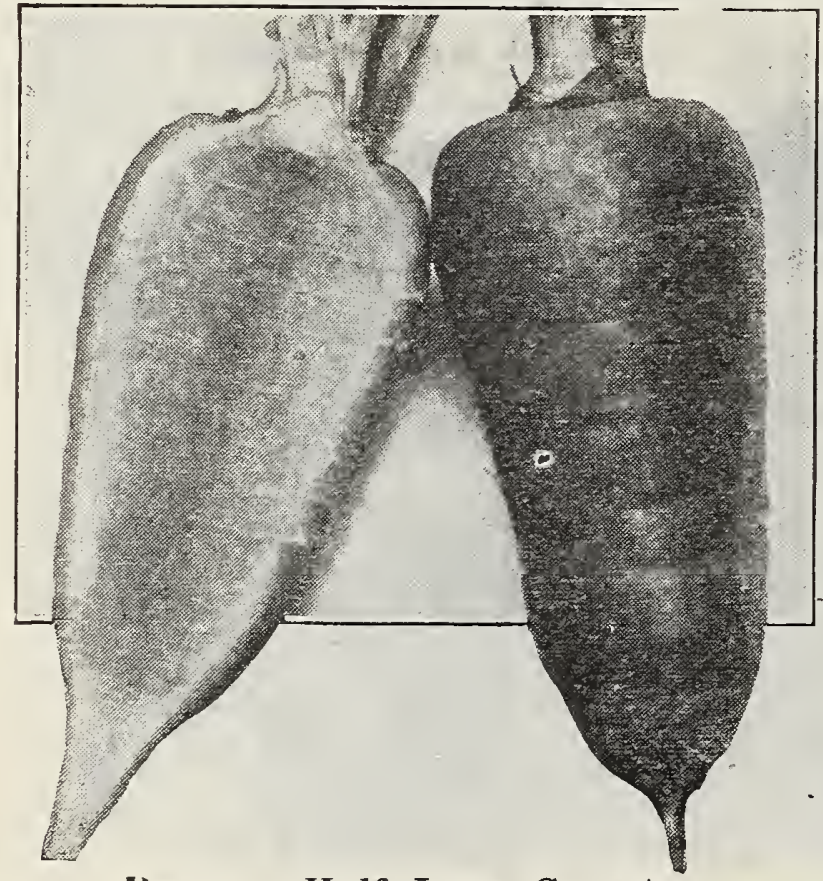

lanvers IHalf Iong Carrots.

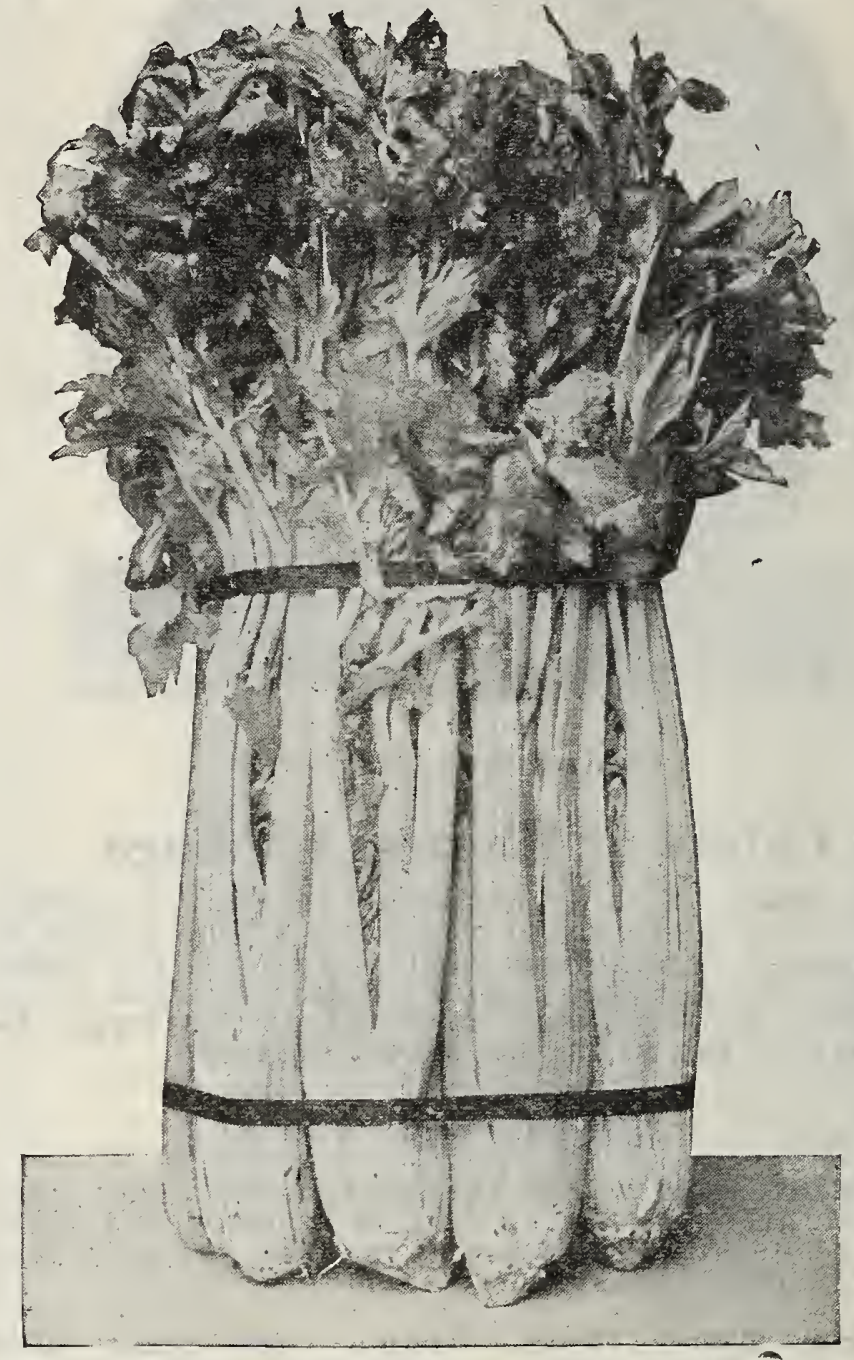

Golden Self-Blanching Celery.

Improved Long Orange.-Is the longest and latest kind, valued for its remarkable keeping qualities. Requires from May to September to reach full size. Properly stored, it will remain in fine table condition from the time it is put in the cellar until the new crop of extra early sorts is ready to be pulled in the garden. Roots long, rich orange color and uniform in length. Pkg., 5e; oz., 10c; $1 / 4$ 1b., 35c; lb., \$1.00, postpaid.

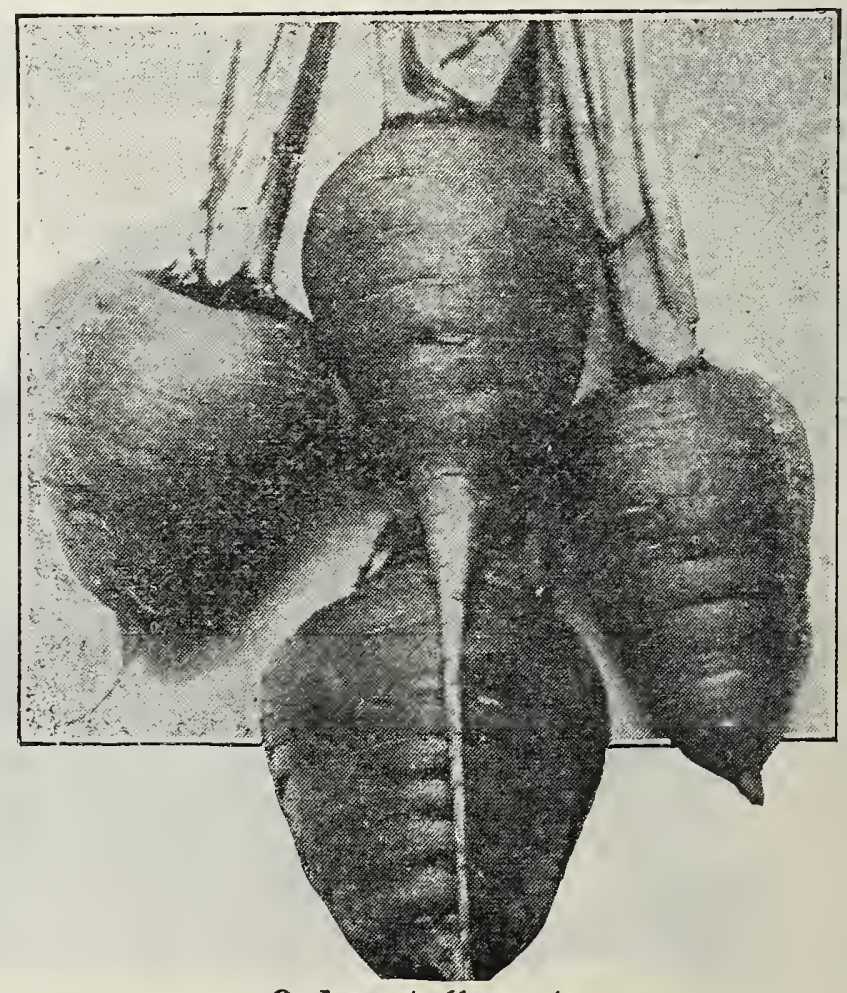

Oxheart Carrots. 


\section{CARROTS-Continued.}

Oxheart or Guerande.-The shortest and sweet. est carrot on the market about 5 inches long, often attaining a weight of 2 pounds. This variety has yielded as high as 1,200 bushels to the acre. Particularly desirable for hard soil being very easily pulled. Pkg., 5e; oz., 10c; $1 / 4$ 1b., 35e; 1b., \$1.00, postpaid.

Chantenay.-A very popular early sort with home gardeners throughout the country. Within 90 to 100 days it produces $3 \frac{1 / 2}{2}$ to 4 inch roots, $1 \frac{1}{2}$

inches in dlameter at the top. rkg., 5c; oz., 10c $1 / 1$ 1b.. 35e; ib., $\$ 1.00$, postpald.

\section{Carrots for Stock Feeding}

Mastodon.-This varlety yields more to the acre than any other sort. Very white, solid flesh, please any one who plants it. Pks., Je; (o., 10e; $1 / 4$ please any one who plants

\section{SWEET CORN}

Nothing is gained by planting seeds before both ground and weather have become thoroughly warm. Sweet corn seeds are soft and will quickly rot in cold soil. One pint of seed will plant $75-$ foot row. Never plant one long row of a kind, but plant corn in blocks of several rows slde by side. It is best to manure poor soil in hills, $21 / 2$ to 3 reet apart, and to plant 5 or 6 seeds to each hill, reducing the plants to the 3 strongest. In fairly fertile soil the best method is to sow the corn in rows about 3 inches deep with 2 or 3 feet between the rows.

At the following prices on corn-Packets and nuarter pounds and pounds are sent prepaid; all iarger quantities are shipped at purchaser's expense. If wanted br parcel post, add postage.

\section{Extra Early Varieties}

Extra Early Varieties.-By ordering early you have the pick of your stock.

Golden Bantam. - After 15 years of most exhausting tests under wldely varying conditions of soil and climate, the nation's critics acclaim "Golden Bantam" as the standard earliest yellow sort of quality by which other kinds should be judged. Ears are just the right size for table use and kernels are deep and very sweet. These are protected by a very heavy husk, thus warding off insects. Pkg., 5e; $1 / 4$ lb., 10c; 1b., 30c; 5 lbs., \$1.25; 10 1bs., \$2.25.

Early Minnesota.-An early white variety, very productive, bearIng ears 7 to 9 rows of large white kernels. Especially desirable for canning. Pkg., 5c; 1/4 1b., 10c; 1b., 30c; 5 1bs., \$1.25; 10 1bs.; \$2.25. seldom over 5 inches long. Pko, 5c; 1/4 1b, 10c; 1b., 30c; 5 1bs, 1.25 10 lbs., $\$ 2.25$.
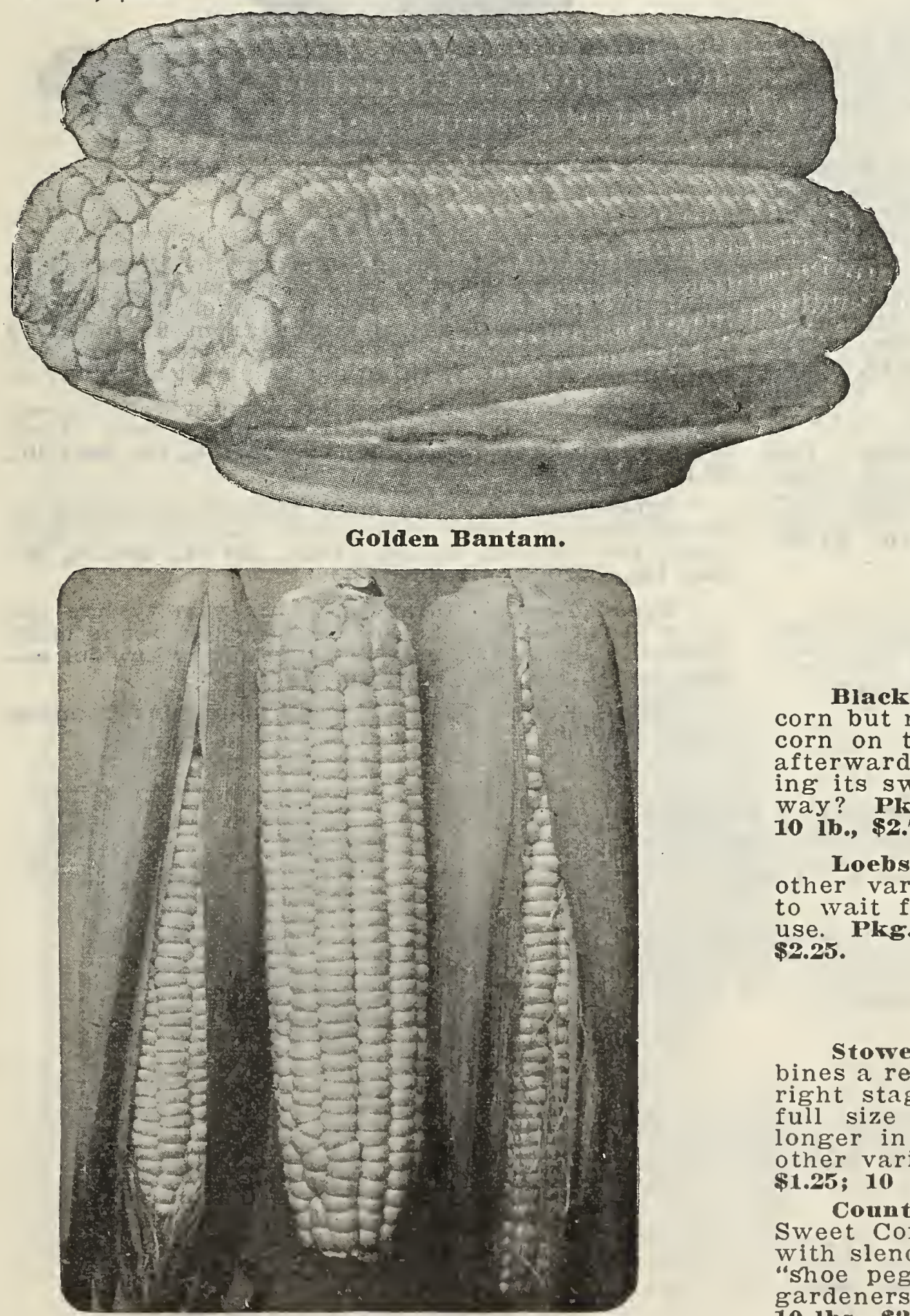

Stowell's Evergreen. 10 1b., \$2.75. $\$ 2.25$. 10 los., \$2.75.

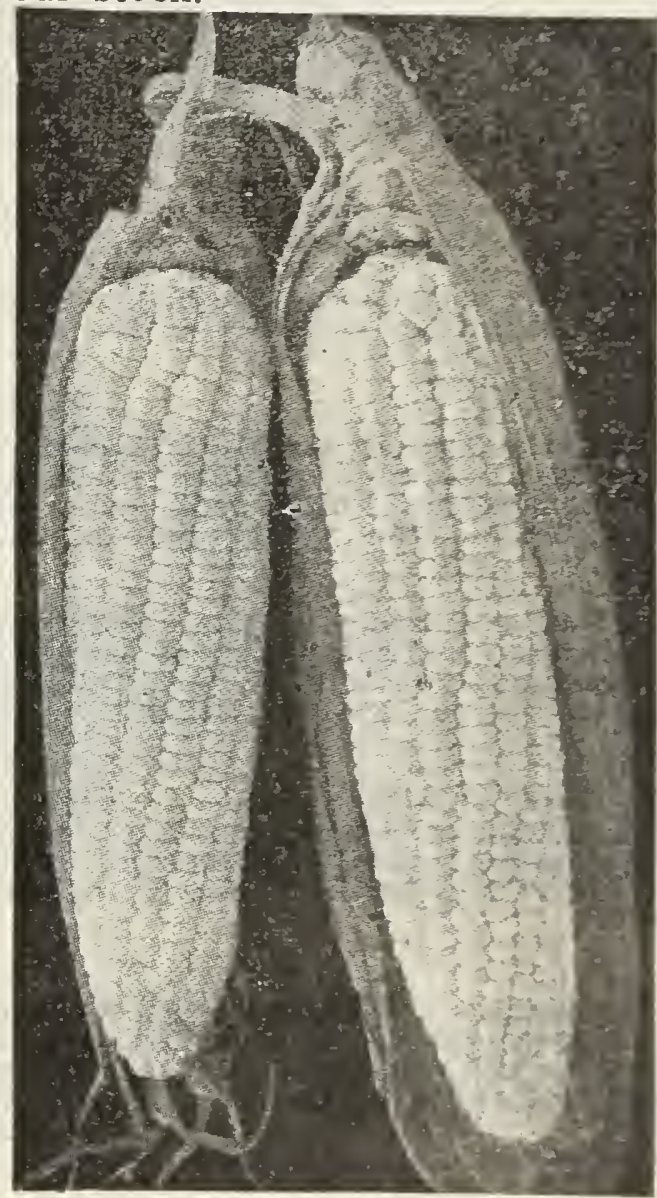

Early Minnesutu.

\section{Second Early Varieties}

Black Mexican.-A very queer variety of stweet corn but more sugary than any other kind of siveet corn on the market. At first the ears are white, afterward becoming a purplish blue but still retaining its sweetness. Why not try one package anyway? PKg., 5e; 1/4 1b., 10e; 1b., 35e; 5 lbs., \$1.50;

Loebs Portland.-This is not as early as some other varieties but $1 t$ will more than repay you to wait for it. Recommended highly for general use. Pkg., 5c; 1/4 1b., 10c; 1b., 30; 5 lbs., \$1.25; $101 \mathrm{bs.}$

\section{Late Varieties}

Storvell's Evergreen.-Ears large sized, it combines a remarkable quality if ears are piclied at the right stage. The average time for ears to reach full size is 100 days Very hardy and remains longer in condition sultable for boiling thall any other variety. Pke., 5e; $1 / 4$ 1b., 10e; 1b., 30e; 5 los., \$1.25; 10 lbs., \$2.25.

Country Gentleman.-The oldest variety of Sweet Corn in cultivation today. Very long ears with slender kernels from whence it gets its name, "shoe peg." A very popular valiety with market gardeners. Pkg., 5e; 1/4 1b., 10e; 1b., 35e; 5 1b.s., $\$ 1.50$, 


\section{Pop Corn}

There is always a good demand for Pop Corn. It is just as easily raised as other corn and yields as much or more per acre because it can be planted more closely.

White Rice.-Grains white and shaped llke rice. Very productive. Pkg., 5e; 1/4 lb., 10e; 1b., 25e; 5 lbs., $\$ 1.00$.

\section{Aromatic, Medicinal and Pot Herbs}

Sweet Basil.-Annual. The leaves are used for highly seasoned dishes as well as in soups, stews and sauces. Pkg., 10e; oz., 20c.

Sweet Fennel.-Perennial. Tea made from the seed is an excellent remedy in case of colic and stomach complaints. Pkg., 10c; oz., 20c.

Dill. - Annual. It is cultivated for its seeds, which are used medically and for flavoring pickles. Pkg., 10c; oz., 20c.

Marjoram, Sweet.-Leaves used for seasoning. Pkg., 10c; oz., 20c.

sage.-Perennial. Tea made from these leaves is an excellent means of producing sweat. Plkg., 10c; oz., 20c.

Safiron.-Annual. The dried flowers are used for medicinal purposes. Pkg., 10e; oz., 20c.

Caraway-Kreummel.-The seeds are used for flavoring. Pkg., 10e; oz., 20e.

Coriander.-Annual. Its tender leaves are sometimes used for soups and salads. Pkg., 10e; oz., 20c.

Thyme.-Leaves and young shoots used for seasoning; a tea is made of the leaves; a remedy for headache. Pkg., 10e; oz., 20c.

\section{HERBS.}

NO GARDEN IS COMPLETE WITHOUT A FEW CUCUMBERS

Seeds should not be sown until the soil and weather have become quite warm. Make a furrow $1 / 2$ inch deep, running it in circular form, about 4 inches in diameter, around top of hill and scatter about a dozen seeds in it. Cover and press soil down firmly with your hands. The richer the soil, the more may grow.

Improved Long Green.-Medium early, spineless sort, uniform in size, extremely hardy. It retains its dark green color until it is ripe. Under favorable conditions it will produce fruits 10 inches long. Pkg., 5e; oz., 15c; 1/4 1b., 40c; 1b., \$1.30, postpaid.

Early Frame or Short Green.-A very prolific variety producing uniform sized, straight fruits of bright green. Considered very good for pickles. Pkg., 5e; oz., 15e; 1/4 lb., 40e; 1b., \$1.30, postpaid.

Davis' Perfect.-An elegant variety for slicing. Perfectly straight, uniform fruits, dark greem An ox., 15c; $1 / \mathbf{4} \mathbf{l b . ,} \mathbf{4 5 e ; 1 b . , ~ \$ 1 . 5 0 . ~}$

Early White Spine.-A universal favorite with the truck gardeners on account of its earliness. Very crisp, excellent flavor. Medium size, dark green. Pkg., 5e; oz., 15e; 1/4 1b., 40 ; lb., \$1.40, postpaid.

Chicago Pickling.-Grown extensively for pickles alone. Fruits, small, pointed at both ends, covered with spines. Those who relish crisp, tender pickles will be more than pleased with this "variety. Pkg., 5e; oz., 1c; 1/4 1b., 40e; 1b., \$1.20, postpaid.

Early Green Cluster.-Very prolific, producing its fruits in clusters near the roots of the vine. Short green, especially recommended for pickling. Pkg., 5e; oz., 15e; $1 / 4$ 1b., 40e; 1b., \$1.30, postpaid.

\section{Kohl Rabi}

For a very early crop; seeds may be sown in a seed flat indoors, about the middle of March. When the seedlings make the second pair of leaves thin them out to stand an inch apart in the row, about 2 feet between the rows, cultivate like cabbage.

Early White Vienna.-Very delicate sort, ready for use in 60 days. Very delicious boiled and served with cream dressing like turnips or cooked and sliced cold as a salad. Pkg., 5e; oz., 25; 1/4 1b., 85e; 1b., \$3.10, postpaid.

\section{Kale, or Borecole}

Member of the cabbage family varying in character of plant in that the individual leaves are carried on stems that grow away from the main stalk instead of leaning toward same, as in the, case of cabbage. Sow seeds early in the same manner as radishes are sown.

Dwarf Green Curled.-Dwarf habit of growth. Plants spreading 2 feet or more and growing about 18 to 20 inches high. Ready in 75 to 90 days. Pkg., 5e; oz., 25e; 1/4 1b., 85e; lb., \$3.10, postpaid.

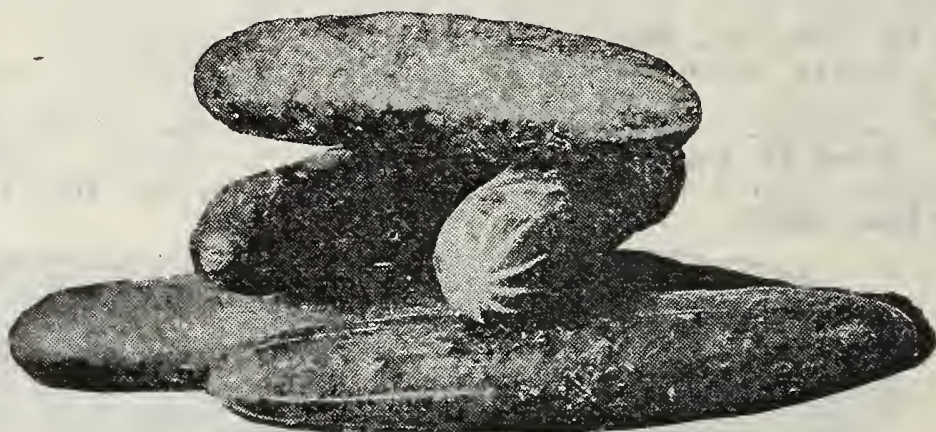

Improved Long Green Cucumber.

\section{Endive}

Sow as soon as the ground can be prepared in rows 18 inches apart covered just enough to hold em in the furrows. When 4 inches tall they inches apart. Is of a decidedly bitter flavor and

Green Curled.-Is the kind most widely known grown. Large leaves very finely cut. Very isp and tender. Pkg., 5c; oz., 20c; 1/4 1b., 60c; 1b.

White Curled.-The most attractive variety as t requires no extra blanching. Leaves very pale green ribbed with yellow. Pkg., 5c; oz., 20c; $1 / 4$ 1b.,

Broad Leaved Batavian.- This variety has the large broad leaves. It can be blanched but is more generally used for greens as spinach. Pkg., 5e; oz., 1b., 60c; 1b., \$2.10, postpaid.

Stop! Look! Listen! Read about our Crimson Giant Radish.

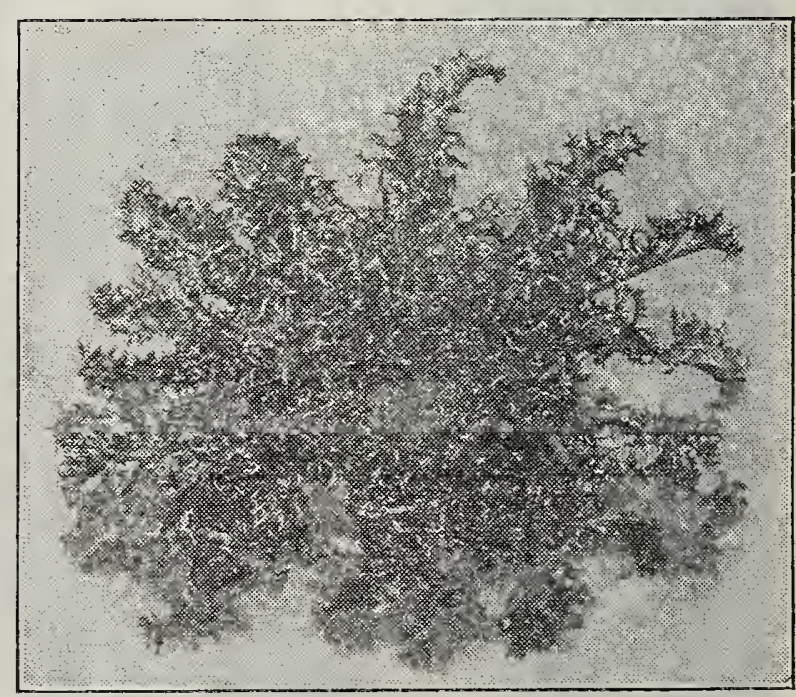

Dwarf Green Curled Kale.

Take no chances-buy Crimson Giant Radishes. See page 15 for particulars. 


\section{Egg Plant}

Sow seeds in rich soil middle of February, in hotbed asid keep in an even temperature about 65 degrees. Unless you comply, with these suggestions, growing Egg Plants from seed will prove a disappointing experiment. Sow seeds thinly in furrows 4 inches apart, covered about $1 / 4$ inch deep with light, sandy loam and soil should be kept thoroughly moist. When seedlings form the second pair of leaves they should be transplanted putting them 4 inches apart each way. Repeat transplanting several times before plants are set into the garden. Do not be in a hurry to set the plants out because the cool nights do not agree with this plant. Hoeing is very essential.

New York Purple Spineless.-Requires from 150 to 160 days to reach full size. Grows to be 8 inches long by 6 inches in diameter, having a beautiful blackish purple skin. Very prolific. Pkg., 10e; oz., 40e; 1/4 lb., \$1.25, pestpaid.

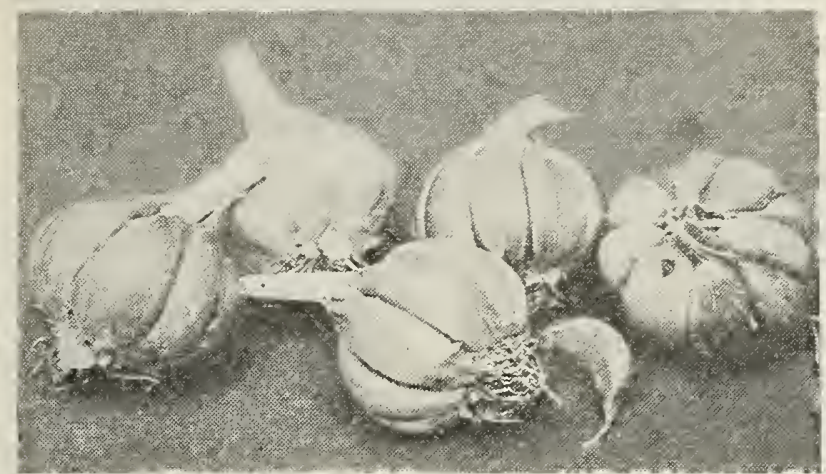

Garlic.

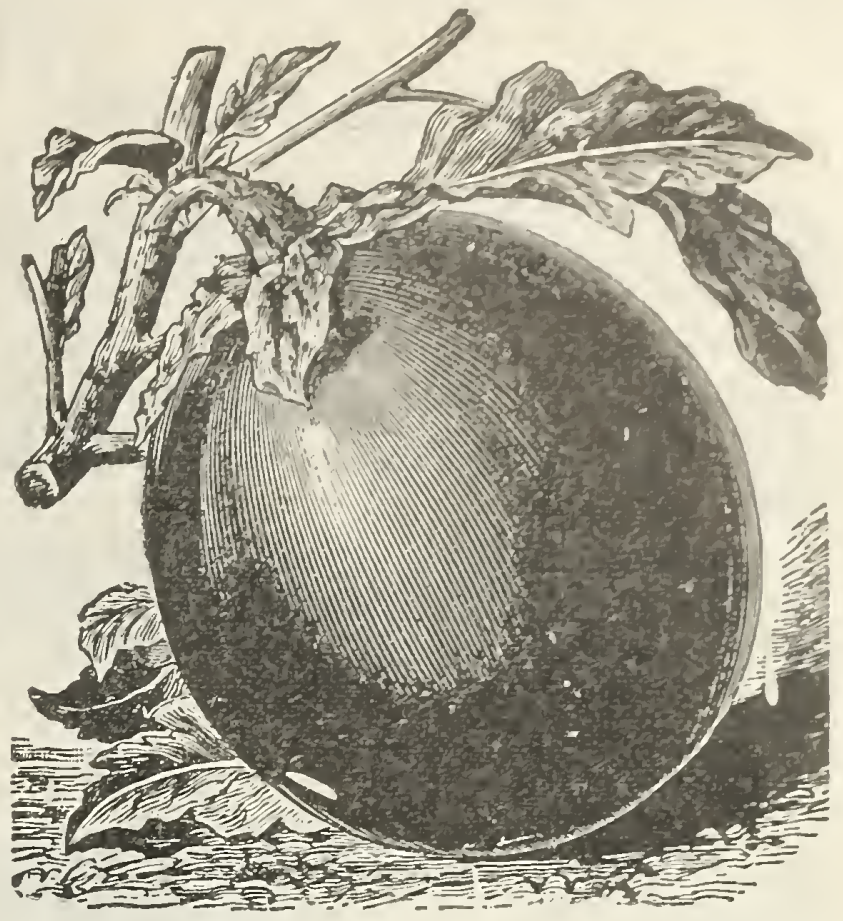

New York Purple Spineless Egg Plant.
Garlic

Sets, resembling onion sets, should be planted early in spring, same as onions, covered about 2 inches deep. The bulbs should not be removed until the leaves turn yellow. 1/4 1b., 20c; 1b., 60c; 5 lbs., $\$ 2.50$.

\section{Leek}

American Flag.-Closely related to Onions from which they differ in being of milder fiavor and in not forming bulbs. Instead, the plants have flat leaves which form long fleshy stalks. Very hardy and may be left in the ground all winter. Pkg., 10e; oz., 20c; $1 / 4$ 1b., 70c; 1 b., $\$ 2.60$, postpaid.

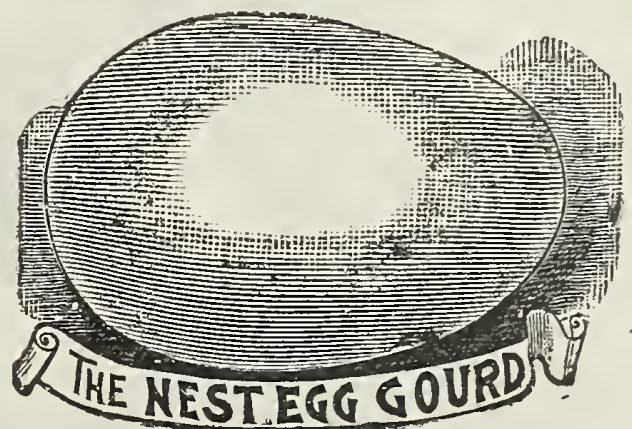

Dipper Gourd. -Sh a p e resembling a dipper. Very useful for many household needs. Pkg., 10c: oz., 25e; $1 / 4$ lb. 85e: 1 b., $\$ 3.10$, postpaid.

Japanese Nest Egg.-Used widely as a vine for shading porches, e tc. Producing litte white eggs Pkg., 10c; oz.o 25c; $1 / 4$ lb., 85e; 1b. \$3.10, postpaid.

\section{LETTUCE}

Any soil will grow Lettuce, although a well-enriched soil will most quickly produce the cholcest heads. Sow seed early in rows 2 feet apart, covering about $1 / 4$ inch deep. Sorts that do nicely during the cool spring months will not form heads during the summer. In order to have the best success you should keep continually thinning it out, never allowing plants to crowd one another.

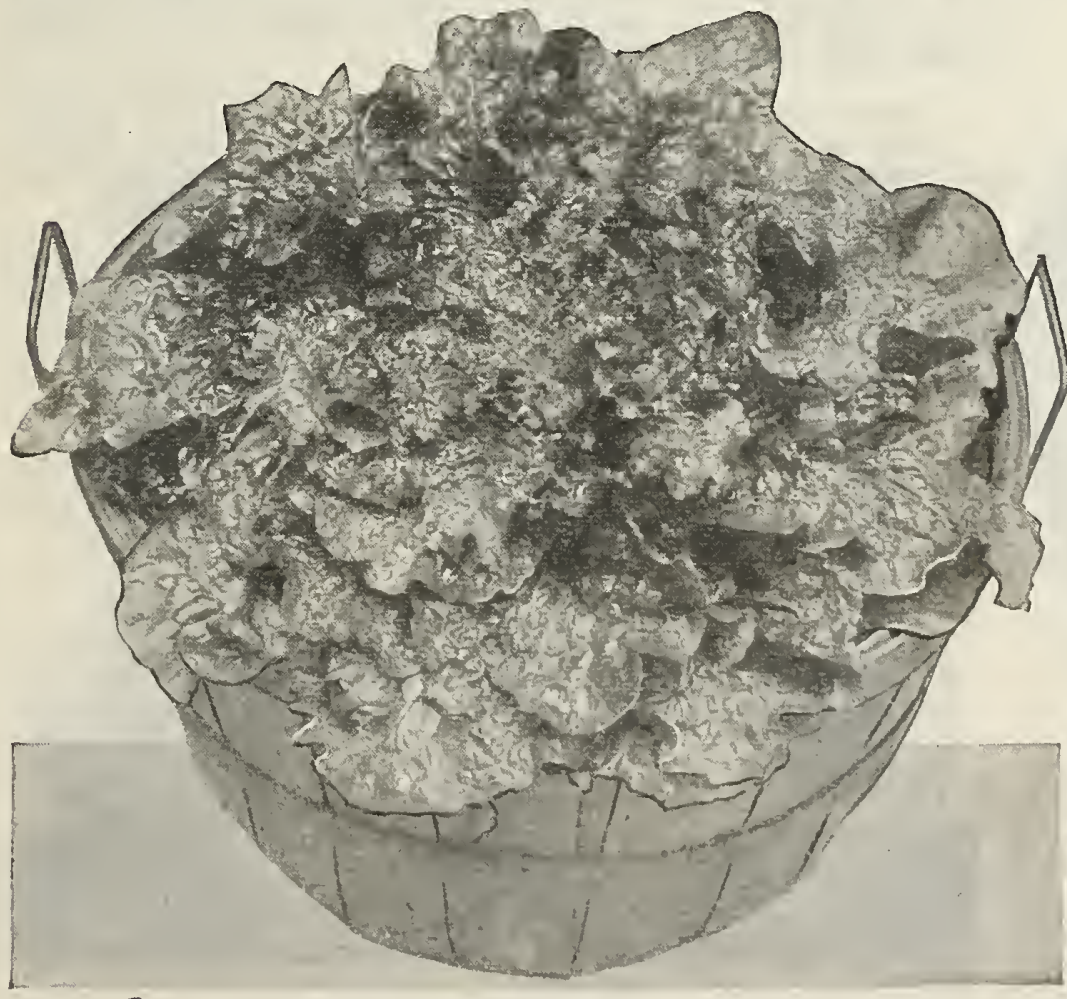

Black Seeded Simpson Lettuce.

\section{Curled or Loose Leaf Varieties}

Black Seeded Simpson.-Forms handsome plants, a foot in diameter within 50 days after seeds are sown. In a rich moist and warm soil which favors rapld development it is far superior to any other variety. An excellent variety on account of its remarkable abllity to vithstand the heat. Pkg., 5c; oz., 15e; $1 / 4$ 1b., 40e; 1b., \$1.40, postpaid.

Tilton's White Star.-A more curly variety. Very tender crimped crispy leaves. We recommena this variety. Pkg., 5c; oz., 15e; 1/4 1b., 40e; 1b., \$1.40, postpaid.

Prize Head.-The most popular lettuce in the world today. Untrue to its name as it does not form a head. Large loose green leaves with outer tips a reddish brown color. You will not be disappointed in this variety. Pkg., 5e; oz., 15e: $1 / 3$ 1b. 40e; lb. $\$ 1.30$, postpaid.

Grand Rapids. - A more curly varlety than the Black Seeded Simpson. Especially desirable for truck gardeners as it does not wilt as easily as most varieties. Pkg., 5e; oz., 15e; 1/4 1b., 40c; lb. 


\section{LETTUCE-Continued.}

\section{Crisp-Head Varieties}

Big Boston.-A very hardy large heading variety with very broad smooth leaves. An excellent variety for shipping. Pkg., 5e; oz., 15e; $1 / 4$ lb., 40c; 1b., \$1.40, postpaid.

Improved Hanson.-A very distinct silvery shade of light green. Considered one of the best varieties on the market because it keeps so long flavor. Pkg.,5c; ozo, 15c; 1/4 1b., 40c; 1b., \$1.30, postpaid.

Iceberg.-Perfects slim, conical-shaped heads of yellowish green, with the center leaves tinged red and curled along the edges. Is ready in 60 days and remains fit for two weeks. Pkg.,5e; oz., 15e; $1 / 4$ lb., 40c; lb., $\$ 1.40$, postpaid.
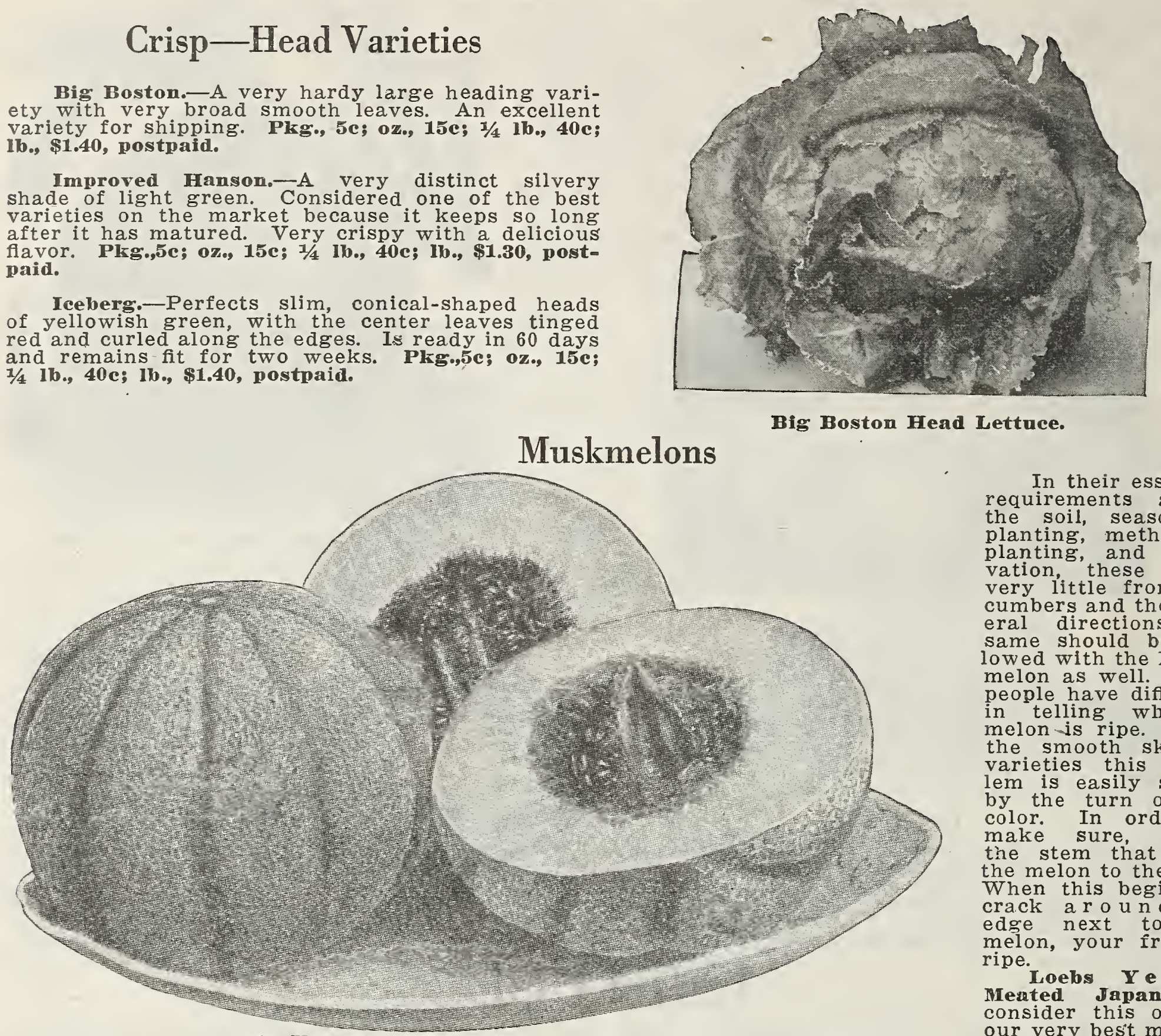

In their essentlal requirements as to the soil, season of planting, method of planting, and cultivation, these differ very little from cucumbers and the gen. eral directions for same should be followed with the Muskmelon as well. Most people have difficulty in telling when a melon is ripe. With the smooth skinned varieties this problem is easily solved by the turn of the by the turn of the color. In order to make sure, notice the melon to the vine. When this begins to crack around the edge next to the melon, your truit is ripe.

Loebs Y e 110 W Mented Japan.-Wo consider this one of our very bes't melons. The fruit when ripe

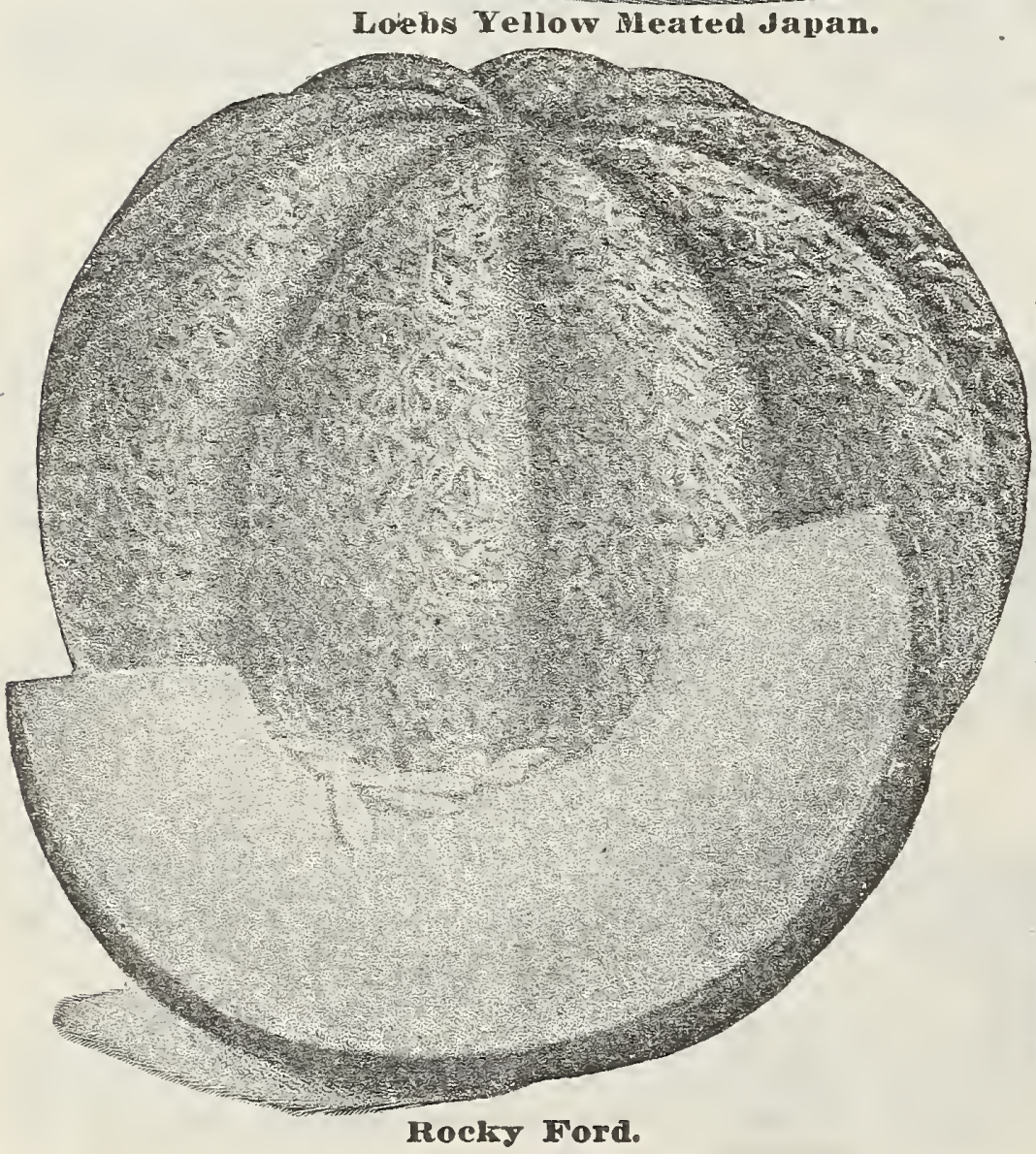

is a beautiful salmon color, very sweet. Particularly well adapted to cool sections, in warm localities they must be picked promptly as the hot sun will quickly turn the flesh soft. Pkg., 5c; oz., 15e: $1 / 4$ lb., $40 \mathrm{c}$; $1 \mathrm{~b} ., \$ 1.30$, postpaid.

Paul Rose or Petoskey.-A very popular melon on account of its small seed capacity. Very sweet and juicy. A light greenish yellow color when ripe. Pkg., 5c; oz., 15c; 1/4 1b., 40c; lb., \$1.30, postpaid.

Rocky Ford.-Nearly round, flesh of a light reenish color Very sweet and can be eaten close 1 the rind. This variety of melon sells for almost wice as much as any other melon. Rust resistant. 'kg., 5c; oz., 15c; 1/4 1b., 40c; 1b., \$1.30, postpaid.

Osage.-Sometimes called Miller's Cream. Medium size, oval shape and salmon colored flesh. The vines are exceedingly vigorous and productive. Pkg., 5c; oz., 15c; 1/4 1b., 40c; 1b., \$1.30, postpaid.

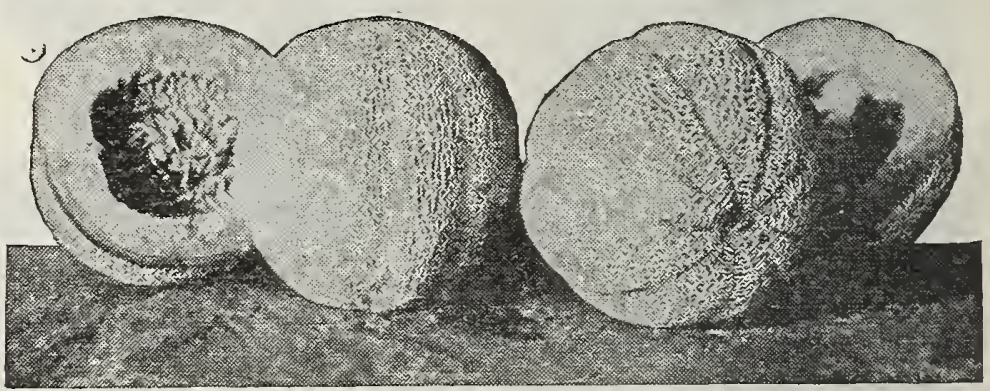

Netted Gem. 


\section{ORDER NOW}

\section{MUSKMELONS-Continued.}

Netted Gem.-When fruit is ripe its color turns a light golden color. Light green flesh and very luscious flavor. Pkg., 5e; oz., 15c: 1/4 1b., 40c: $1 b$.

Garden Lemon.- Resembles very much in hablt \$1.40, postpaid.

of growth, the melon peach. Fruits are round, somewhat smaller than the melon yeach, has thinner flesh and is decidedly more acid in flavor. I'k ox., 15c; $1 / 41$ 1b., $40 ; 1 b ., \$ 1.40$, postpaid.

\section{WATERMELON}

Thrive anywhere where the temperature remains about 60 degrees for at least 100 days. Not particular as to soil, though a sandy loam suits them best Hills should be placed at least 9 feet a jart each way as the vines grow so rapidly. From 6 to 10 seeds are generally placed in a nill and only 1 to 2 plants should be allowed to develop. The vines are exceedingly tender and resent being moved about. tramped upon, or bruised or injured in any way.

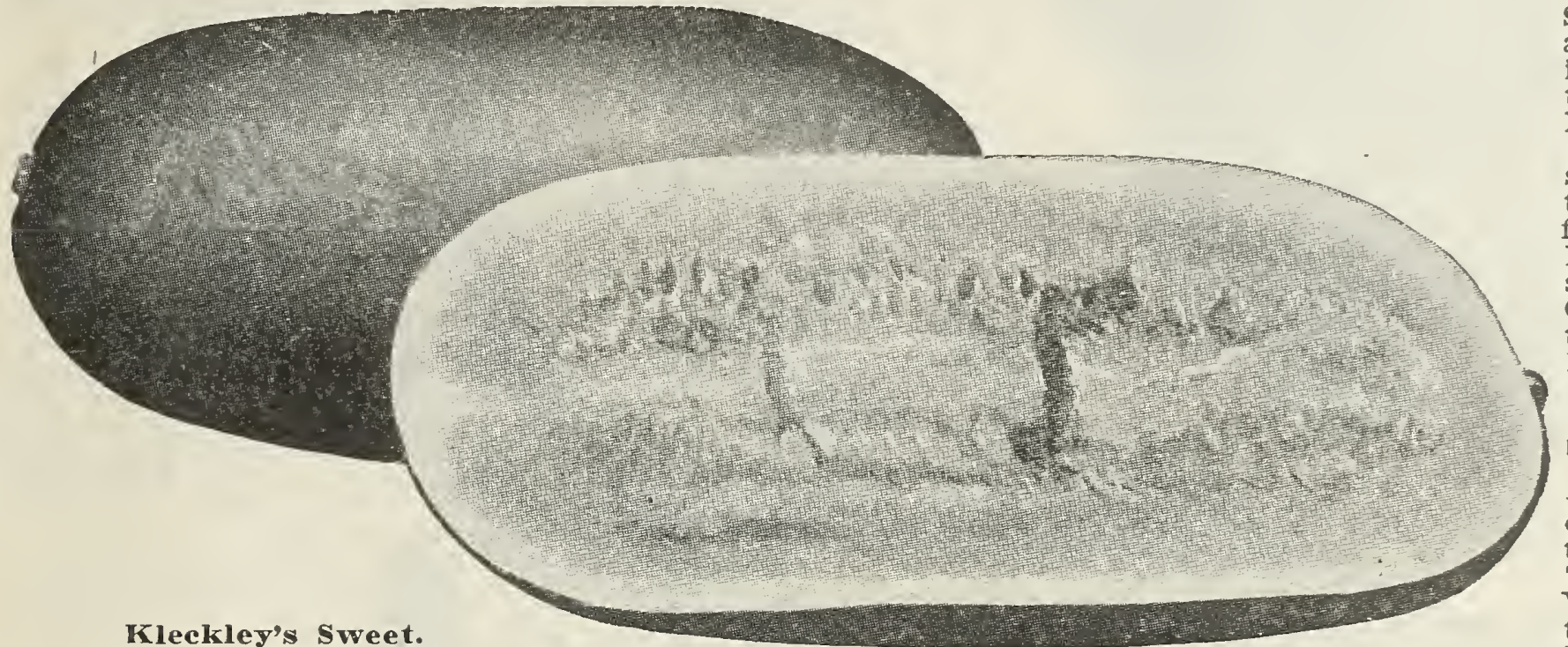

K 1 e c k l e $\boldsymbol{y}^{\prime}$ Sweet. - Th $\theta$ ity is found in this very large. this very large, green - skinned sort. Renowned the world over for its especial $1 \mathrm{y}$ delightful s w e e $t$ flavor. Give them a trial this year. Pkg., 5c; oz. 10c: 1/4 1b., 25c lbe; 80 , post jaid.

Cole's Early. - One of the earliest varieties, ripening in 75 to 80 days. Very solid with thin rind, and $\mathrm{bright} r \mathrm{hd}$

oebs Klondyke.-Delícious, exquisitely flavored extra early melon. Bright red flesh very firm and exceptionally thin rind. Pkg., 5e; oz., 10c; 1/4 lb., 25c; lb., 80c, postpaid.

25c; 1o., 80c, postpaid. top of a barrel, even larger, under favorable conditions, and is of a truly elegant quality. It is a round, dark skinned sort, an ideal home gard.en sort and a good one for market. It is the earliest ripening sort, combining good quality with fair size. Pkg., 5c; oz., 10c; 1/4 1b., 25e; 1b., 80c, postpaid.

Kentucky Wonder.-This variety bears longer than most varieties. Very light seeded and of gor size, though not too large. Excellent for shipping. Pkg., 5c; oz., 10e; 1/4 1b., 25c; 1b., 80c, postpaid. Citron.-Small, round, green fruits used for preserves only. Red seeded and white flesh very solid and firm. Pkg., 5e; oz., 15e; 1/4 1b., 50c; lb., $\$ 1.60$, postpaid.

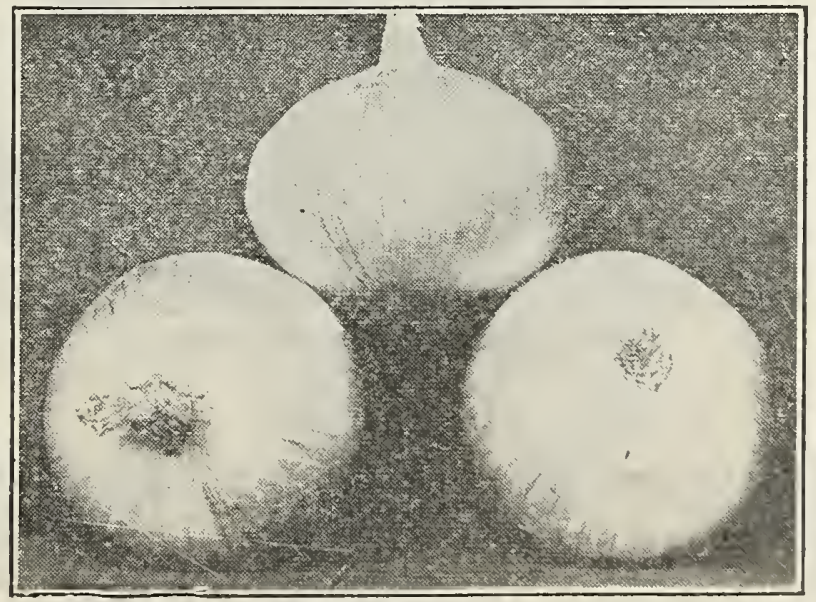

White Bermuda Onions.

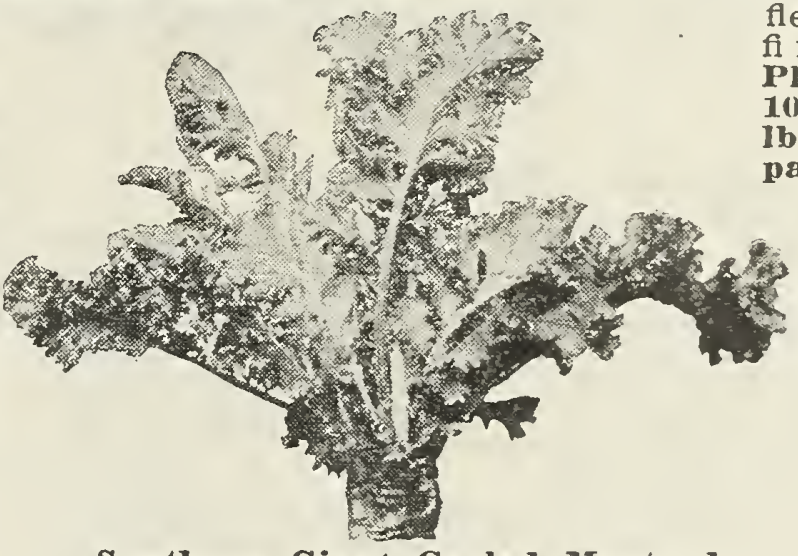

Southern Giant Curled Mustard.

\section{Mustard}

For greens the seeds are sown thinly in rows, twelve to 18 inches apart and are covered $1 / 4$ inch deep. Seedlings are thinned out to stand 4 inches and later 8 inches apart. Plants must be used before flower buds appear which cause the leaves to become of strong flavor. Sow short rows repeatedly up to May.

Chinese.-Leaves extremely large and are prepared for greens the same as Spinach. Also used for flavoring salads and soups, etc. Pkg., 5c; ox. 15e; $1 / 4$ 1b., 35e; $1 \mathrm{~b} ., \$ 1.10$, postpaid.

Southern Giant Curled-Leaves are large but crimpled and frilled on the edges. This varlety has a much more delicate flavor than the Chinese Curled. Pkg. 5c: oz. 15c: 1/1 1b.35c; 1b. \$1.10, postpaid.

\section{ONIONS}

Sow seeds in the spring as early as possible. Make furrows about 1/2 inch deep and place them 12 to 18 inches apart. Sow the seeds thinly, about 3 or 4 to every inch. or on an average of 1 oz. $t 0$ a 50 feet of row. Seedlings will appear in from 10 to 14 days, when the first hoeing should be done. Prompt and repeated weeding is absolutely necessary. Do not hill onion rows. Be very choice in your selection of seeds or sets and do not buy cheap, inferior sorts. WVe carry a very select vartety of onion seeds. Order early and get the kind that you want. Our orders for onion sets are not shipped until all danger of frost is over. By placing your order for sets early, you have them on our first shipment out. 


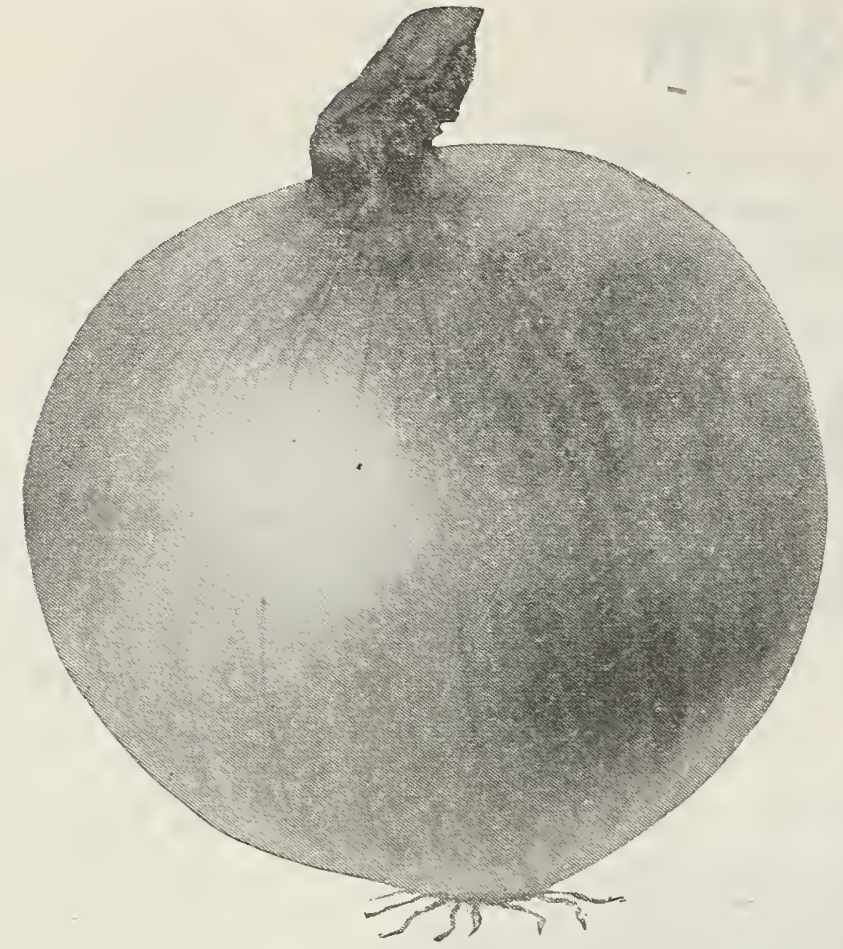

Minnesota Red Globe.

Danver's Yellow Globe.-Very heavy yielder of handsome, coppery-yellow. skinned bulbs, averaging $21 / 2$ to 3 inches in diameter within 135 days. Pks. 5c; oz., 25c; 1/4 1b., 85c; 1b., \$3.00, postpaid.

White Bermuda.-Distinctly flat, thin skinned $21 / 2$ to 3 -inch bulbs that reach us from Texas and other southern states during the late winter and very early spring. Very mild flavor and heavy yielder. Should be planted is the all and transplanted later. Pkg., 10c; 0z., 30c; $\%$ 16., \$1.00; 1 b., \$3.50, postpaid.

Loebs Silver Skin Pickling Onions.-A pickling onion. Within 85 to 90 days it yields small $11 / 2$ to 2 -inch bulbs which are highly esteemed for putto 2-inch bulbs which are highly esteemed for putmild flavor. Pkg., 10c; oz., 30c; 1/4 1b., \$1.00; 1b. mild flavor. P.

\section{Bottom Onion Sets}

Culture.-Soil requirements the same as for onion seed. Place the Onion sets 3 to 4 inches apart according to size, 3 inches deep, in rows 1 foot apart. It is customary to furrow out the soil with a little hand plow early in the spring; set the onion in this furrow right side up and cover with a garden rake, and if the soil is dry it should be well firmed over the sets. Twelve to fifteen bushels of sets required for an acre.

These are the product of seed and are used for "Green Unions" or to produce larger onions, which they do much quicker than can be grown from seed.

Plant Bottom Onion sets for table use. They produce large onions ready for market or home use from four to six weeks earlier than can be done by from four to

Market Gardeners and Truckers will find it to their advantage to get our quantity prices. We are headquarters.

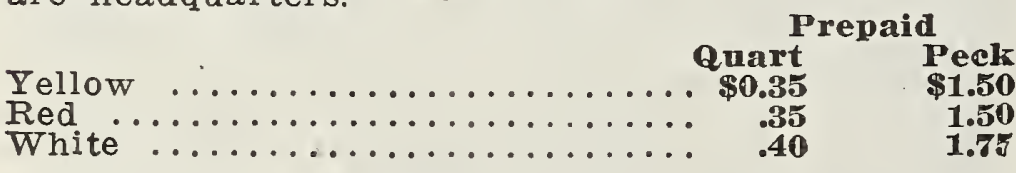

\section{Parsley}

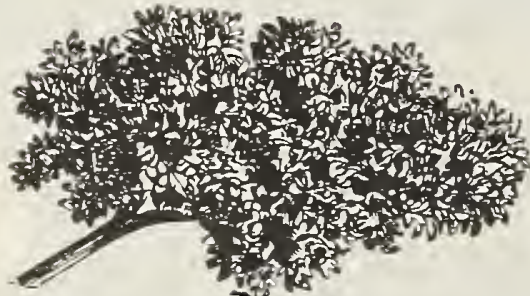

Sow seedis as early in the Spring as the ground can be prepared, in a $\mathrm{r}, \mathrm{w}$, d rop ping $t h$ e $m$ to $s$ a ce thinly. Cover from $1 / 8$ to $1 / 4$ inch deep $1 / 8$ to $1 / 4$ inch deep, and allow 18 to 24 and allow 18 to 24 inches between the rows. This seed is very slow to germinate and often a month will elapse before enough, to stand 6 inches to a foot apart.

Dark Moss Curled.-Very dense foliage of green crimped leaves used especially for a garnish. Pkg.,

\section{Three Superb Globe Onions}

Minnesota Red Globe. The Globe onions are considered the best variety in existence. This variety is the largest, but also the latest and strongest in flavor of the Globe onions. Its globeshaped 3 inch bulbs ripen in 140 days from date seeds are sown. Pkg., 5c; oz., 25e; 1/4 1b., 85e; 1b., \$3.00, postmaid.

Minnesota White Globe-This is the handsomest sort in cultivation today. With symmetrical shape and beauty it combines good size, superb quality and really remarkable keeping qualities for a winter sort. In 120 days after seeds are sown the bulbs will average $21 / 2$ inches in diameter both ways The skin is well until January. Pkg., 10c; oz., 30c; 1/4 1b., \$1.00: well until January.

Minnesota Yellow Globe.-Largest and latest of the globe onions, also the heaviest yielder. Average size, 3 inches. Average time to mature, 140 days. The standard yellow in many sections. Pkg., 5e; oz., 25c; 1/4 1b., 85c; 1b., \$3.00, postpaid.

Prizetaker Onion.-A very large and very productive variety. The outside skin is a golden yellow color flesh very firm, sweet, white and tender. low color, flesh very firm, sweet, white and tender.

Large Red Wethersfield Onion. - The standard purplish red sort. Requires 135 days to reach $21 / 2$ by 4 inches in diameter. Flesh white with pinkish tinge, fine grained of strong flavor. An excellent keeper. Pkg., 5c; 0z.9 25c; 1/4 1b., 80c; 1b., \$2.75, postpaid.

Australian Brown.-While not a strictly red sort deserves to be classed as such because of its long keeping quality The bulbs vary from coppery yellow to reddish brown, mature in 130 days, and with careful handling have been known to keep in good condition for a year. Average size 2 to $2 \frac{1}{2}$ inches in diameter. Pkg., 5e; 0z., 25e; 1/4 1b., 85c; 1b., \$3.00, postpaid.

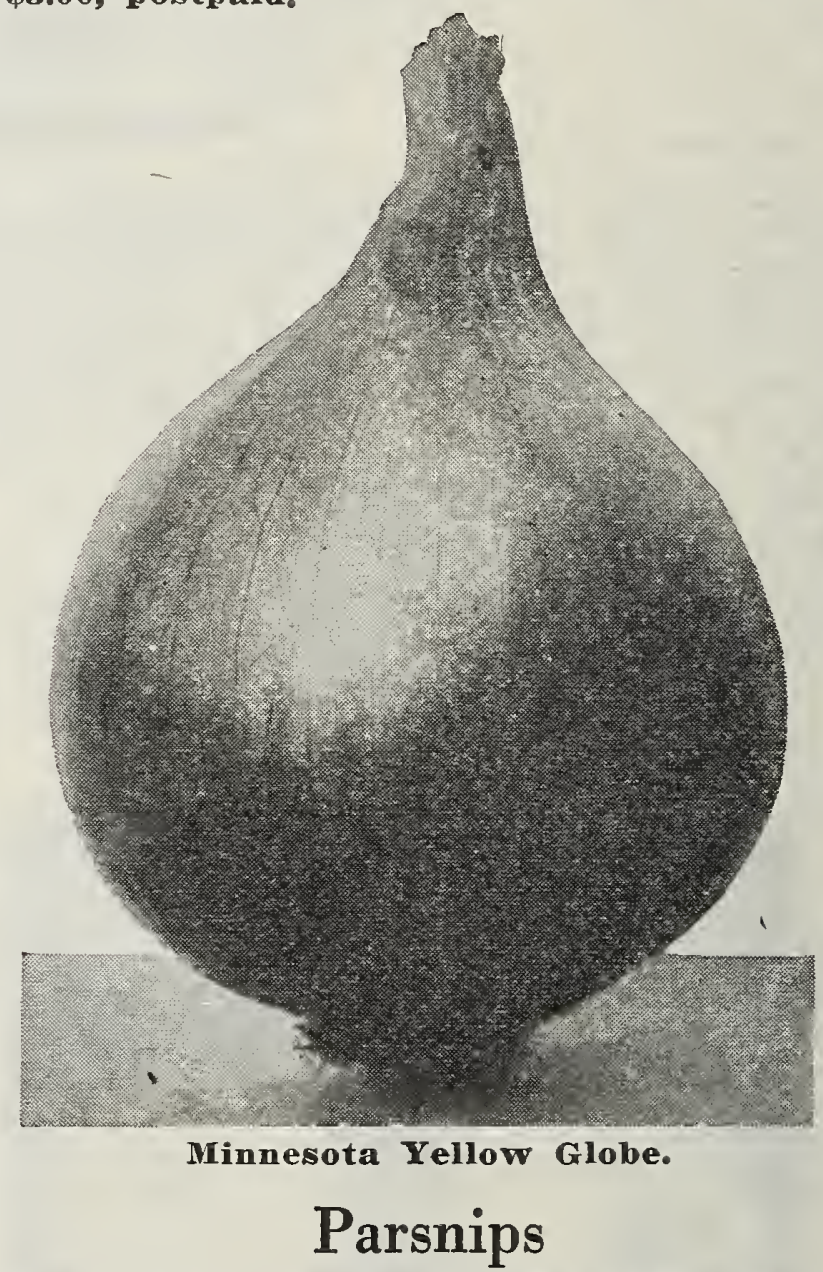

Easily grown in all sections and all soils. Seeds should not be sown until the ground is warm, gen erally about the middle of May. Cover about $1 / 2$ inch deep and allow 18 to 24 inches between the rows. It requires about 130 days for roots to reach full size.

Improved Hollow Crown.-Long, smooth roots, with dep heavy yielder. Considered the best Parsnip for either market or private use. Fkg., 5e; oz., 10c 1/4 1b., 35c; 1b., \$1.00, postpaid.

Improved Guernsey.-Roots not as Iong as the Hollow Crown variety but greater in diameter. Very easily gathered and a very heavy yielder. Very fine grained flesh, exceptionally sweet and tender. Pkg., 5c; oz., 10c; 1/4 1b., 35c; 1b., \$1.00, postpaid. 


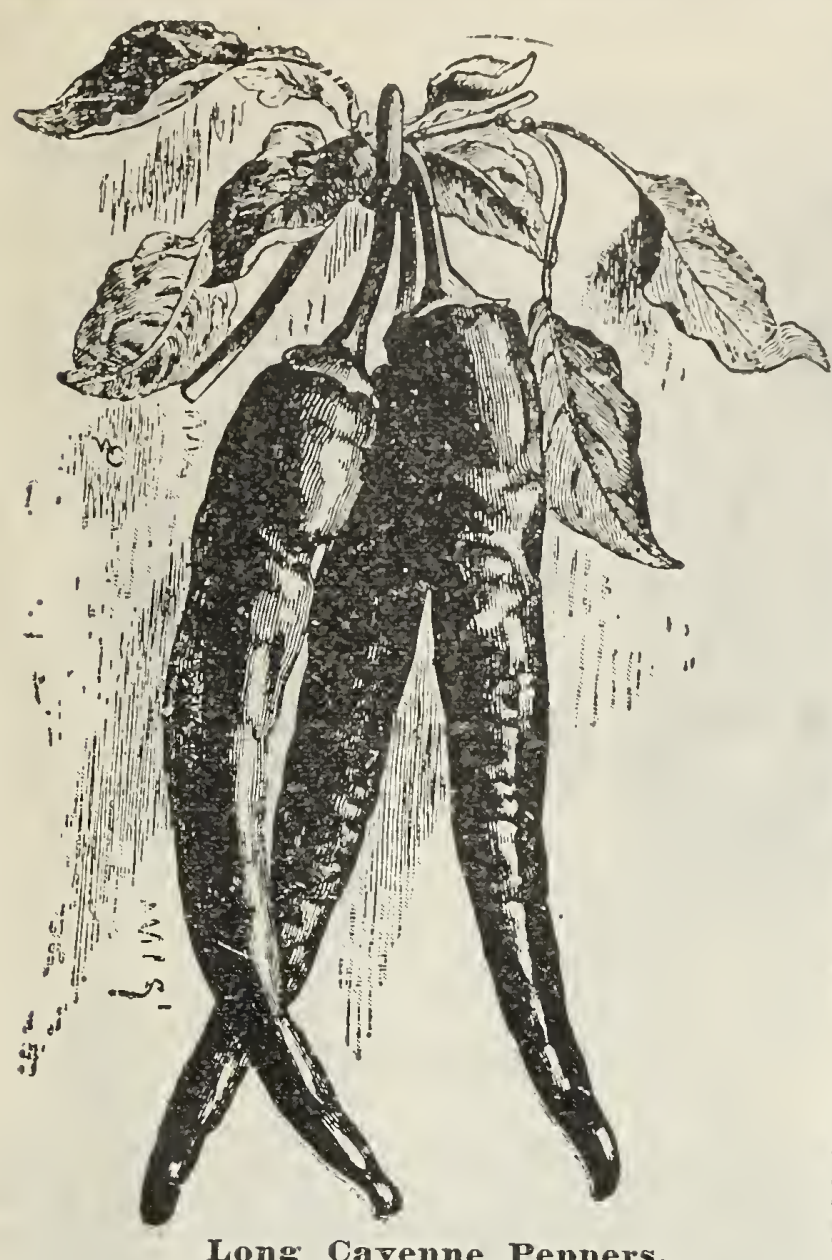

\section{Peppers}

These are distinctly warmth loving plants and evory effort should be made to keep them in a constantly growin condition. Seeds are sown late in February in greenhouses. Pepper seed seidom germinates strongly andition

dificult to maintain. It is therefore 1

wise to sow seerls rather thickly and transplant the seedlings as soon as they are large enough to be handled

dong Cayenne.- The variety generally used in the mak ing of Chili Sauce. Very spicy and hot. Long slim pointed pods of a bright red when ripe. Pkg., 15e; 0\%, (30); 1/a lh. \$2.00; 1b., \$6.00, postpaid.

Chinese Giant.Largest and latest of the mangoes. Exceptionally fine for salads and stuffing owing to its sweet Havored gr e e n pods. ripe the $y$ turn a bright scarlet color. Pks., 15e; oz., 80c; 1/4 1b. \$3.00; 1b., $\$ 9.00$, postpaid.

$\mathbf{R} \mathbf{u}$ b $\mathbf{Y}$ K i n g.Another very mild variety growing to the enormous size of $41 / 2$ to 6 inches long and from 3 to 4 most popular variety with market gardeners on account of its ttractive a p parance. Pkg., 15c; oz., $75 \mathrm{c}$; $1 / 4$ lb., $\$ 2.50$; $1 \mathrm{~b}$.,

Long Cayenne Peppers.

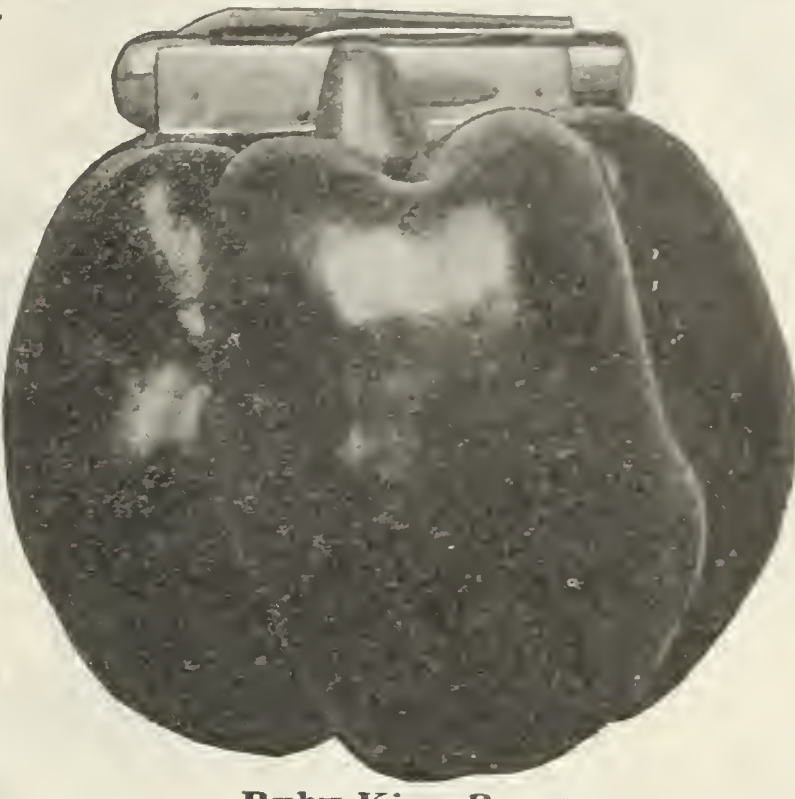

ception of Golden Dawn.-A large variety, very mild and similar to the other peppers with the ex1b., \$2.50; $1 \mathrm{~b} ., \$ 8.00$, postpaid.

\section{Peas--Hard Northern Grown Stock}

At the following prices on Peas-packets and quarter pounds and pounds are sent postpaid; all larger quantities are shipped at purchaser's expense.

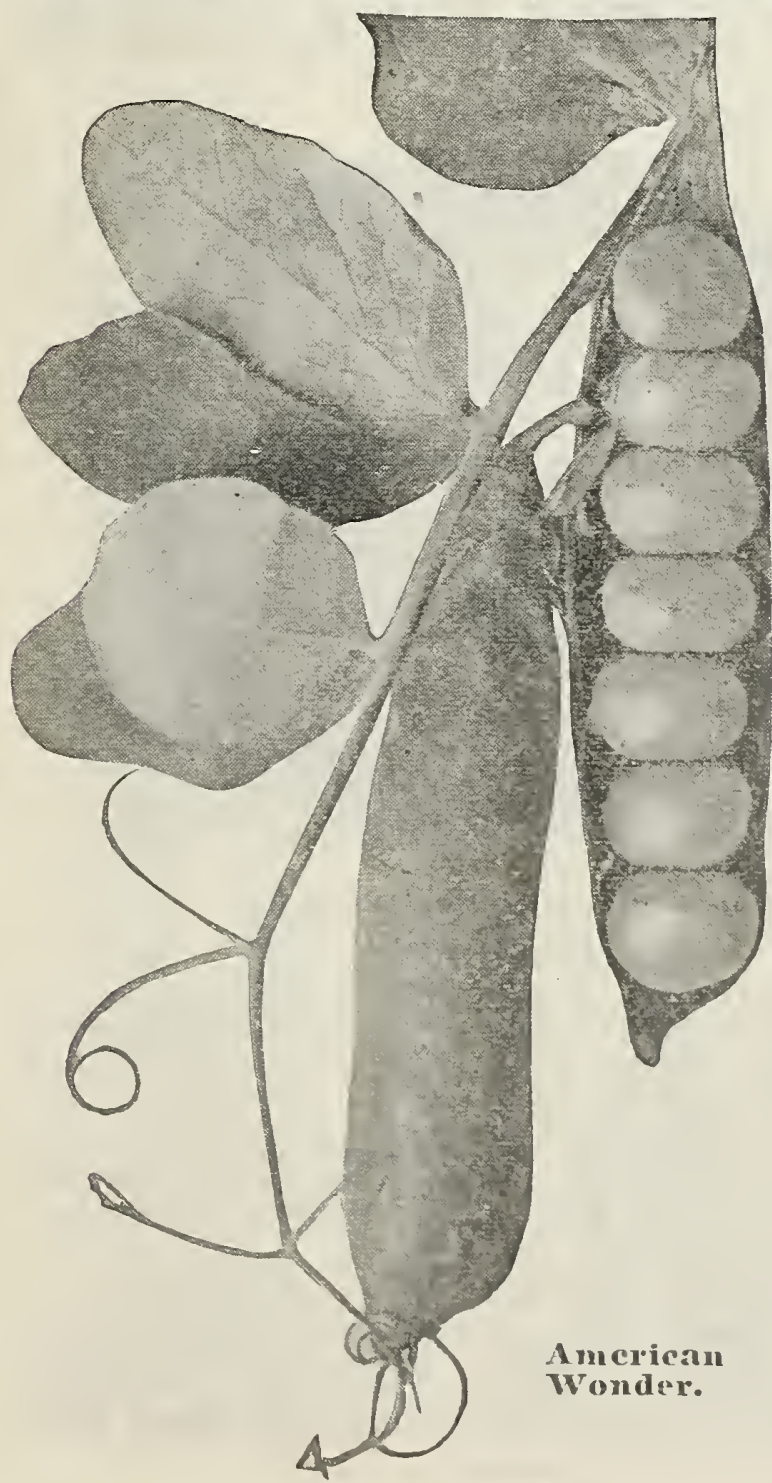

Peas are divided into smooth seeded and wrinkled seeded kinds. The smooth seeded peas are by far the hardiest and may be sown as soon as the ground can be dug. The wrinkled kinds are very much more tender, and cold, wet soil causes them to rot. Sow peas in rows, 2 or 3 peas to one inch or using one pint of seed to every 30 feet of row. Pea roots need air and weeds should not be allowed to hand1cap the development of the young plants.

American Wonder.-An extra early wrinkled varlety producing bushes from \& to 10 inches high with good sized pods of 5 or 8 , large, sweet and tender peas. Especially desirable for private gardeners, as they require no support. Pirable for private gardeners, as they require no sup

Champion of England.-One of the taller varieties attaining the height of 4 or 5 feet. Vines are very vigorous and productive and very delicious flavored peas. The standard main crop or late pea for summer use. Pleg., 5e; 1/2 16., 10c; 1b., 35c; 5 1bs., \$1.50; 10 lbs., \$2.75.

Gradus or Prosperity. - The earliest wrinkled variety maturing only a few days later than the smooth sorts. Vines 3 feet high with small well-filled pods Of all tail main crop peas the Gradus is the most desiraole for the home garden. Pkg., 5c; 1/1 1b., 10c; 1b., 35c; 5llos., \$1.50; 10 lbs., \$2.75.

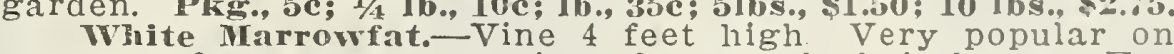
account of the great quantity of peas which it bears Excellent for canning. Peas light yellow color and smooth. Pkg., 5e; $1 / 4$ 1b., 10c; 1b., 25c; 5 1bs., \$1.00; 10 1bs., \$1.75.

Nott's Excelsior.-Resembling the American Wonder, growing slightly higher. A very dependable variety as it is especially easy to grow. Vines vigorous and hardy. Pkg.,

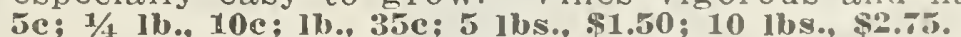

Carter's Daisz.-The leading tall mid-season pea. A dwarf variety requiring no support, producing peas twice as large as the American Wonder. Pkg., 5r; 1/4 lb., 10c: 1b., $35 \mathrm{c} ; 51 \mathrm{loc} ., \$ 1.50: 101 \mathrm{lb}$ s., $\$ 2.75$.

Little Marvel. - Is all the name implies. Within 60 days from sowing seeds the sturdy $1 S$ to 24 inch vines will bear on an average of 8 pods, produced in pairs. They are 3 inches long and are tightly filled with 7 large peas of superb flavor, yielding about 8 quarts of pods per 15 feet of row. Without any contradiction the best pea on the market at the present tim

Dwarf Gray Sugar.-An edible pod variety used in the same manner as string beans. Excellent for pickling. Smooth round peas of a purplisll brown mottled color. Plke, se; $1 / 4$ 1b., 10c; 1b., 30c; $51 \mathrm{bs.}$. \$1.25; 10 lbs., \$2.25.

Little Gem.-A dwarf wrinkled variety similar to the Little Marvel. Our pea seeds are very carefully selected and by placing your order early yrou have the choice of our numerous varieties. Pkg., 5e: 1/4 1b., 10c; 1b., 35e\$5 1bs., \$1.50; 10 lbs., \$2.75. 


\section{PEAS-Continued.}

Everbearing.-True to its name this variety continues to bear longer than most varieties and is undoubtedly the best pea for late summer use. Peas are exceedingly large and very tender. Vines average 3 feet in height. We are sure that you will be pleased with this variety. Pkg., 5c; 1/4 1b., $10 \mathrm{c} ; 1 \mathrm{b.s}, 35 \mathrm{c} ; 5$ los., $\$ 1.50 ; 10$ lbs., $\$ 2.75$.

Horsford's Market Garden.-Vines grow about 2 feet high. Very prolific and fine flavored peas. Their quality is unsurpassed. Medium-sized pods maturing in 60 days.. Pkg., 5c; $1 / 41 \mathrm{~b} ., 10 \mathrm{c} ; 1 \mathrm{~b}$., 35c; 5 lbs., $\$ 1.50 ; 10$ 1bs., \$2.75.

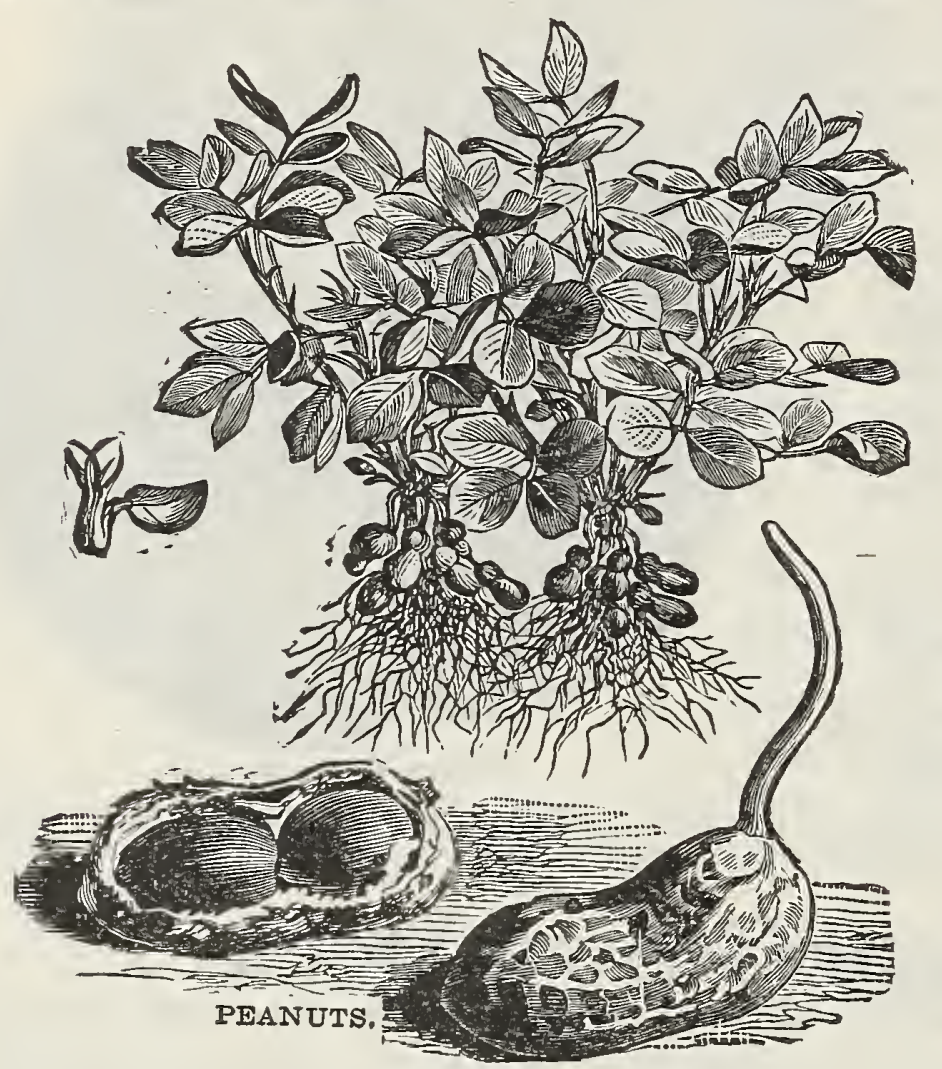

\section{Pumpkin}

Sow seeds in June, as they are very susceptible to cold. Sow in hills, allowing only 2 to grow in each hill. Seedlings appear within a week. Given rich soil they develop very rapidly. They have no insect enemies of any consequence and require but one thing to do well, namely, plenty of moisture. In the cornfield a few seeds are placed in every third or fourth hill of every third, or fourth row, covering them about $1 / 2$ inch deep.

Japanese Pie.-Is a very good sort that keeps splendidly although it is one of the first to ripen. Flesh of deep yellow color and of excellent quality. Pkg., 5c; oz., 10c; $1 / 4$ lb., 45e; lb., $\$ 1.40$, postpaid.

Connecticut Field.-One of the hardiest of all the Pumpkins and a very heavy yielder. Unexcelled for stock feeding. Large yellow color with very heavy shell. Pkg., 5e; oz., 10c; 1/4 1b., 35c; 1b., 90c, postpaid.

Kentucky Field.-A large flattened variety, very popular on account of its remarkable keeping qualities. Good for either stock feeding or eating. Pkg., 5c; oz., 10c; 1/4 1b., 25e; 1b., 70c, postpaid.

Early Sugar or Pie Pumpkin.-The best of all Pumpkins for eating purpose. Very fine fleshed and excellent flavored. Fruit deep orange 8 to 10 in. in diameter. Flesh very sweet and mellow. Pkg., 5c; oz., 10e; $1 / 4$ 1b., 35e; 1b., 90e, postpaid.

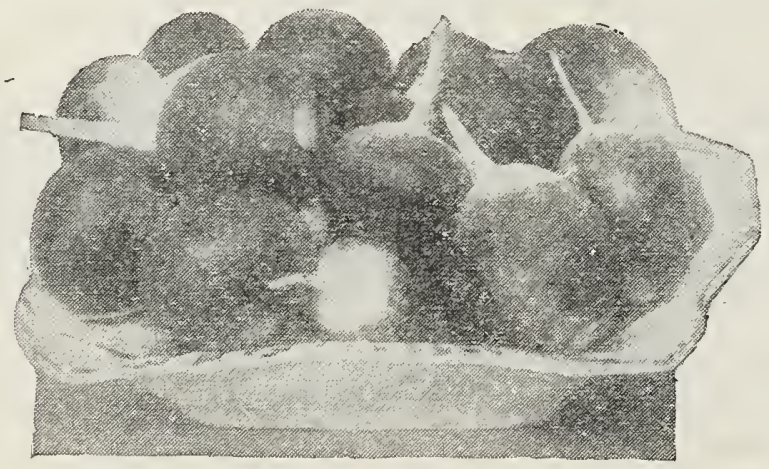

Early Scarlet Turnip Radishes.

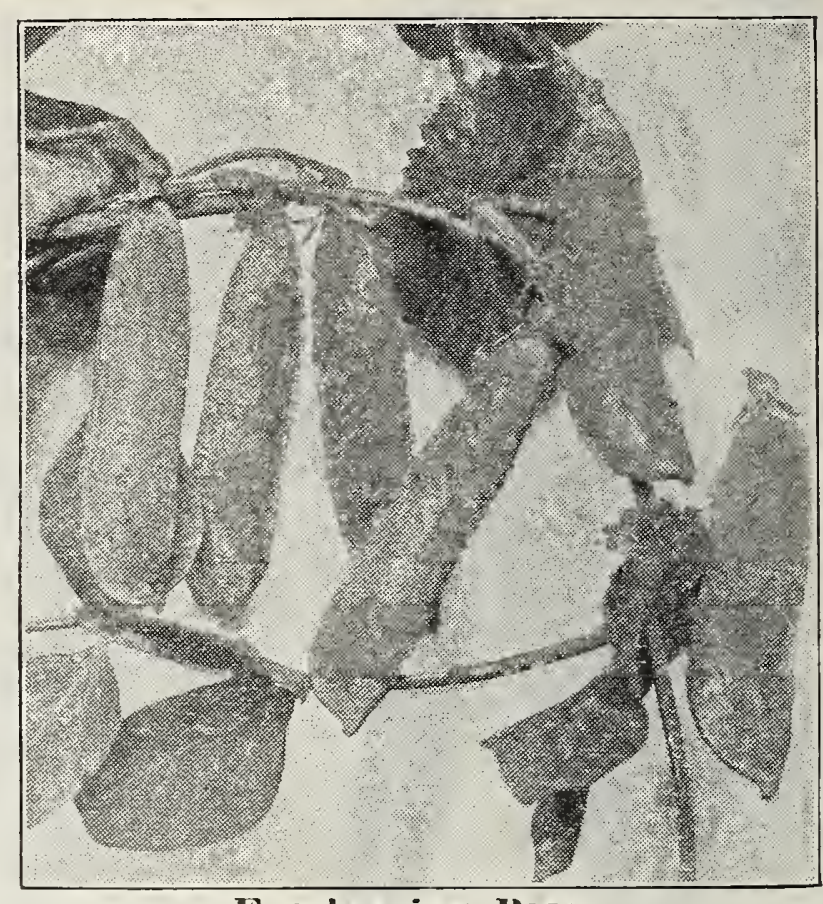

Everbearing Peas.

\section{Peanuts}

Seed can be planted shelled or unshelled. Many growers of the Spanish Peanut soak the unshelled seeds in water just before planting. This hastens the germination. Shelled seed should not be soaked, before planting. Do not plant peanuts until the soil is good and warm. Plant in rows from 28 to 36 inches apart and 9 to 12 inches apart in the rows. Cover about 1 inch deep. The old idea that the blossoms must be covered is erroneous, although many growers allow considerable soil to be thrown over the vines during cultivation.

Small Early Spanish. - Smali podded, strong growers, stems upright, foliage abundant, pods cluster about the base of the plant, two seeds in a po.d, entirely filling the pod. $1 / 2$ lb., 25e; 1b., 40c, postpaid.

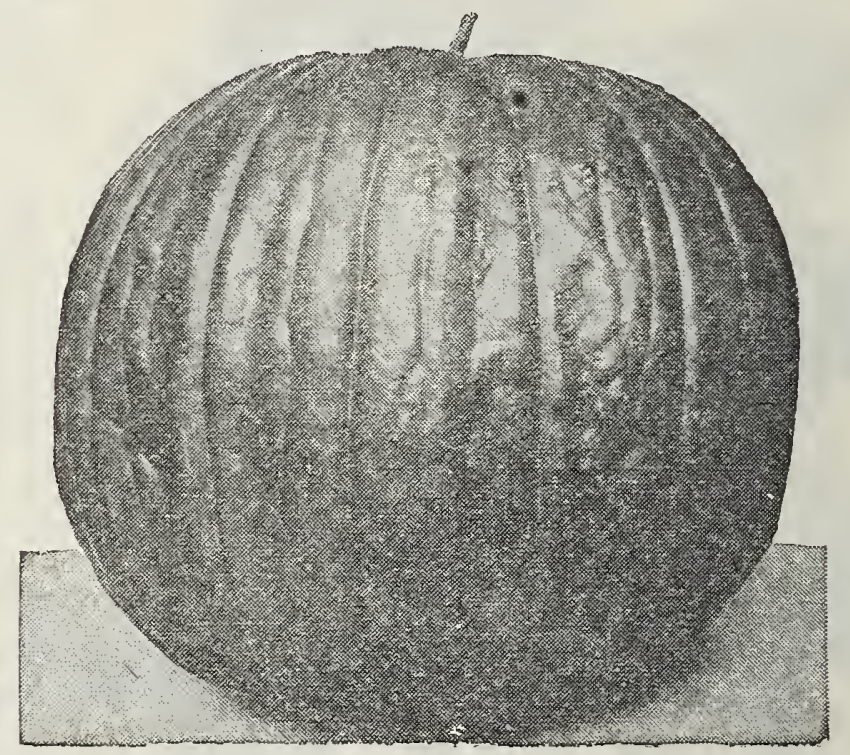

Connecticut Field Pumpkin. Radish

Seed can be sown as soon as the soil can be dug, in rows 12 to 18 inches apart, scattering them so thinly that no more than 2 seeds drop to every inch. Cover $1 / 4$ inch deep. Weed the rows carefuliy and hoe them thoroughly. They must be thinned out enough so that the roots do not crowd one another. Must be grown quickly and not be allowed to become overgrown as they become too strong.

\section{Early Round Radishes}

Early Scarlet Turnip, White Tipped.-A small round radish with white tip. Very mild, crisp, tender and juicy. Extremely early and very prolific. Pkg., 5e; oz., 10c; $1 / 4$ lb., 35c; $1 b ., \$ 1.00$, postpaid. 


\section{RADISHES-Continued.}

Early Deep Scarlet or Non I'lus Ultra.-This is of $1 \mathrm{~m}$ ported French stock and an exceptionally fine sort. Round, globular bright red with pure white fesh, very crisp and delicious. These radishes can be planted very closely owing to their small tops. One of the most attractive varieties on the market. Plkg., 5e; oz., 15e; $1 / 4$ 1b., 45e; 1b., \$1.50, postpaid.

Rosy Gem.-The finest flavored, the coolest, crispest, scarlet radish in the world. Round red with white tip. Pks.. Ee; or., 10e; 1/4 1b., 35e; 1b., \$1, postpaid.

Yellow Ball.-A small round radish, golden colored skin with pure white, crisp flesh. This radish is very popular because it stands so much heat. Pkg., 5e; oz., 15e; 1/4 1b., 45e: lb., \$1.40, postpaid.

Crimson Giant.- You have no doubt noticed the little runners we have elsewhere in this catalog, calling your attention to this particular radish. We are very anxious that all our customers try this excellent variety. They are bright red in color, almost globular in shape and, grow to a ver.y good size and never get pithy like most varieties. Contrary to all other varieties, when they are allowed to become overgrown they do not, even then, get pithy, although they have

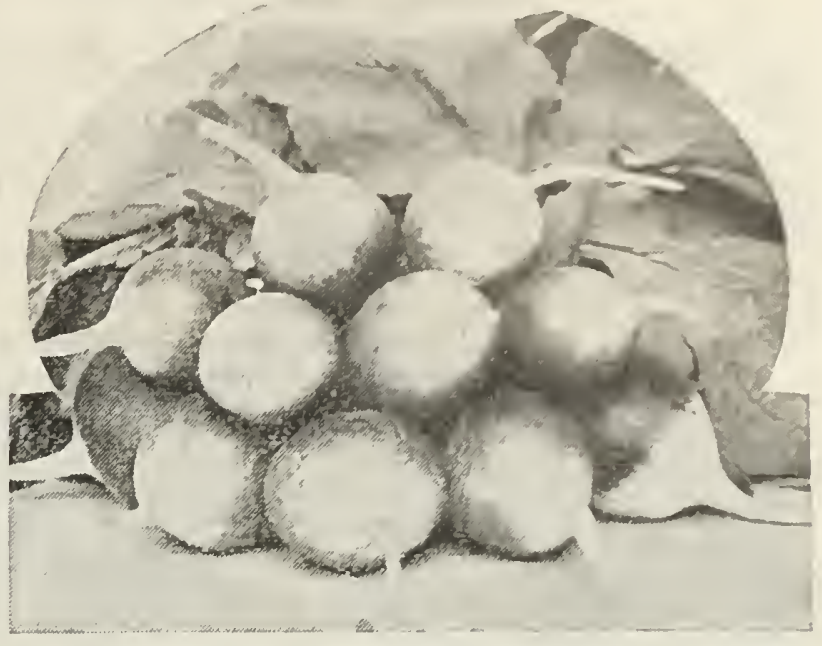

Early Deep Scarlet.

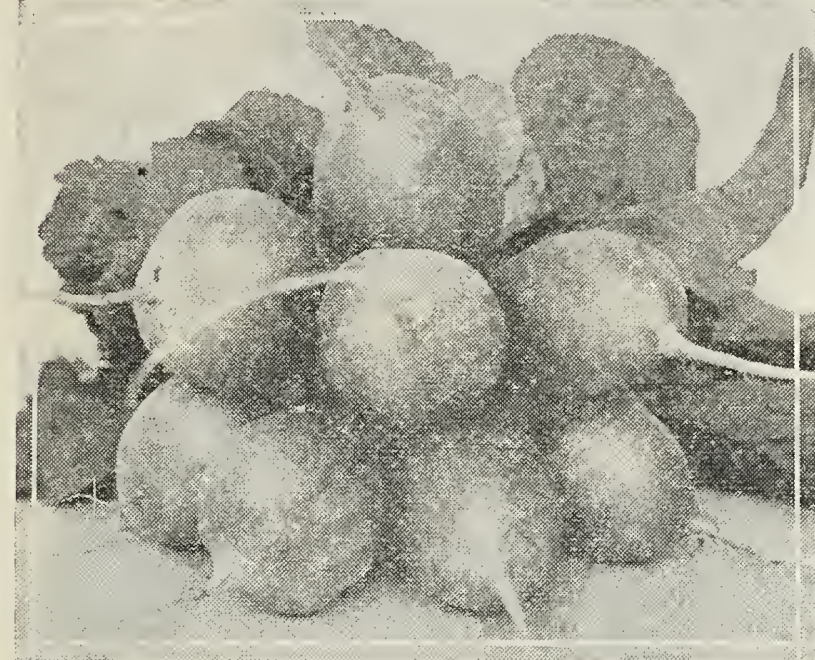

Crimson Giant.

a stronger flavor. There was such a great demand for this radish the latter part of the past season that we have just doubled our contract order for "Crimson Giant" this coming year. If you are looking for perfection, you will find it in this variety, as it is, without a doubt, the best radish on the market When the best costs you no more than the rest, "Why take a chance?" Buy Crimon are taking no chance. Pkg., 5e; oz., 10c; 1/4 lb., 30c; 1b., 90e, postpaid.

\section{Early Olive-Shaped Radishes}

French Breakfast.-One of the earliest varieties. Red with white tip and very short tops. Cne of the most popular varieties. Pkg., 5e; oz., 15c; $1 / 4$ 1b., 45e; 1b., \$1.40, postpaid.

White Stuttgart.-A long, white, top-shaped radish. An excellent keeper for winter use. This is sometimes called a winter radish. Pks., 5e; oz., 15c; $1 / 4$ 1b., 45e; 1b., \$1.40, postpaid.

Earliest White, Olive-Shaped.-Small white radish, very early, maturing in from 16 to 20 days from date seeds are sown. Very crisp, mild and delicious. Pkg., 5e; oz., 10e; $1 / 4$ lb., 35e; lb., \$1, postpaid.

\section{Long Radishes}

White Strassburg.-A long white variety, very crisp and brittle and will stand extremely hot weather better than most radishes. Remain in condition for use longer than the earlier varieties. Pkg., 5c; oz., 15c; 1'4 1b., 45e; lb., \$1.40, postpaid.

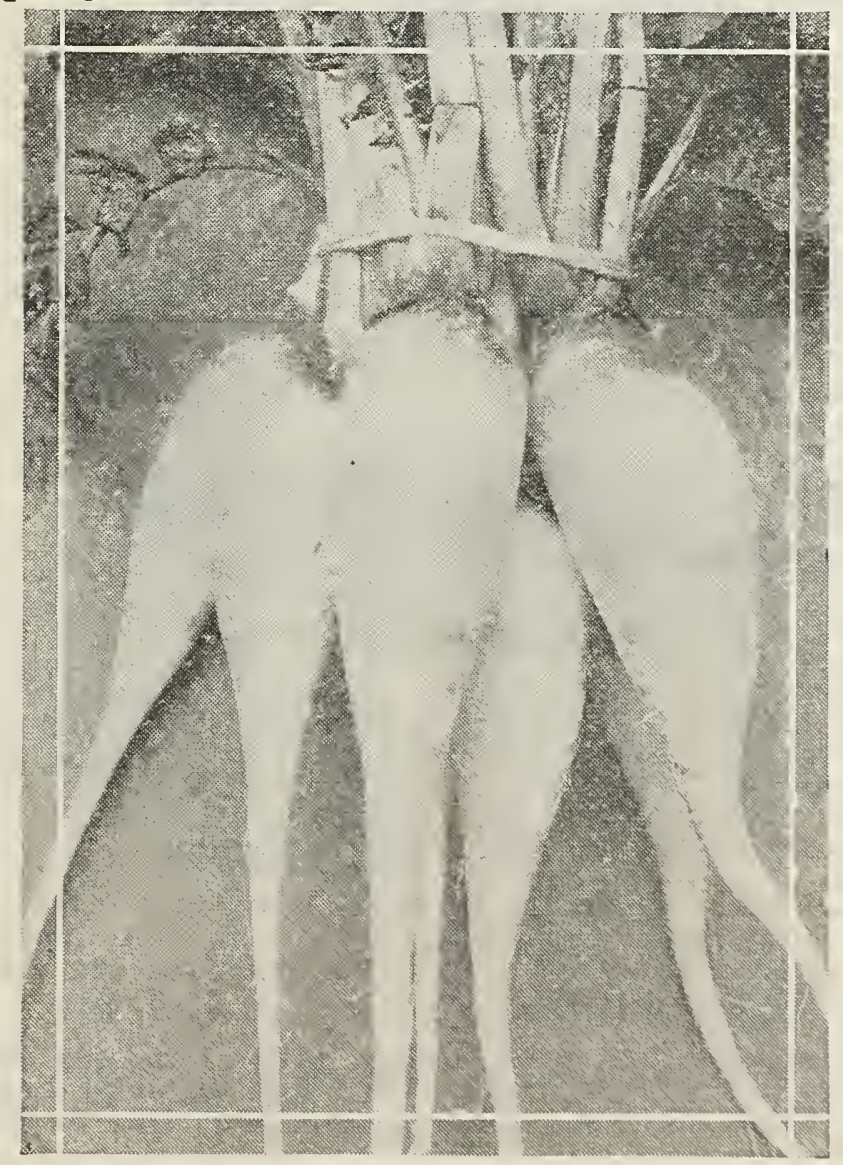

White Strassburar Iradishes.
Long s c a r l e $t$ Short Top.-Long scarlet roots about 6 inches lon $\mathrm{g}$. Very brittle and exceedingly short tops; the roots are grown part way out of the ground and remain crisp until fully grown. Pk. 5e: oz., 10c: $1 / 4$ 1b., 35c; $1 \mathrm{~b} ., \$ 1$, postpaid.

White Icicle. most popular long variety. Long slender white roots $m$ a t u r i $\mathrm{ng}$ three weeks from date seed is sown Sweet, mild and very de li c i o us Pker., Je: oz., 10e: $1 / 4$ 1b., 35e; 1b., \$1, posstpaid.

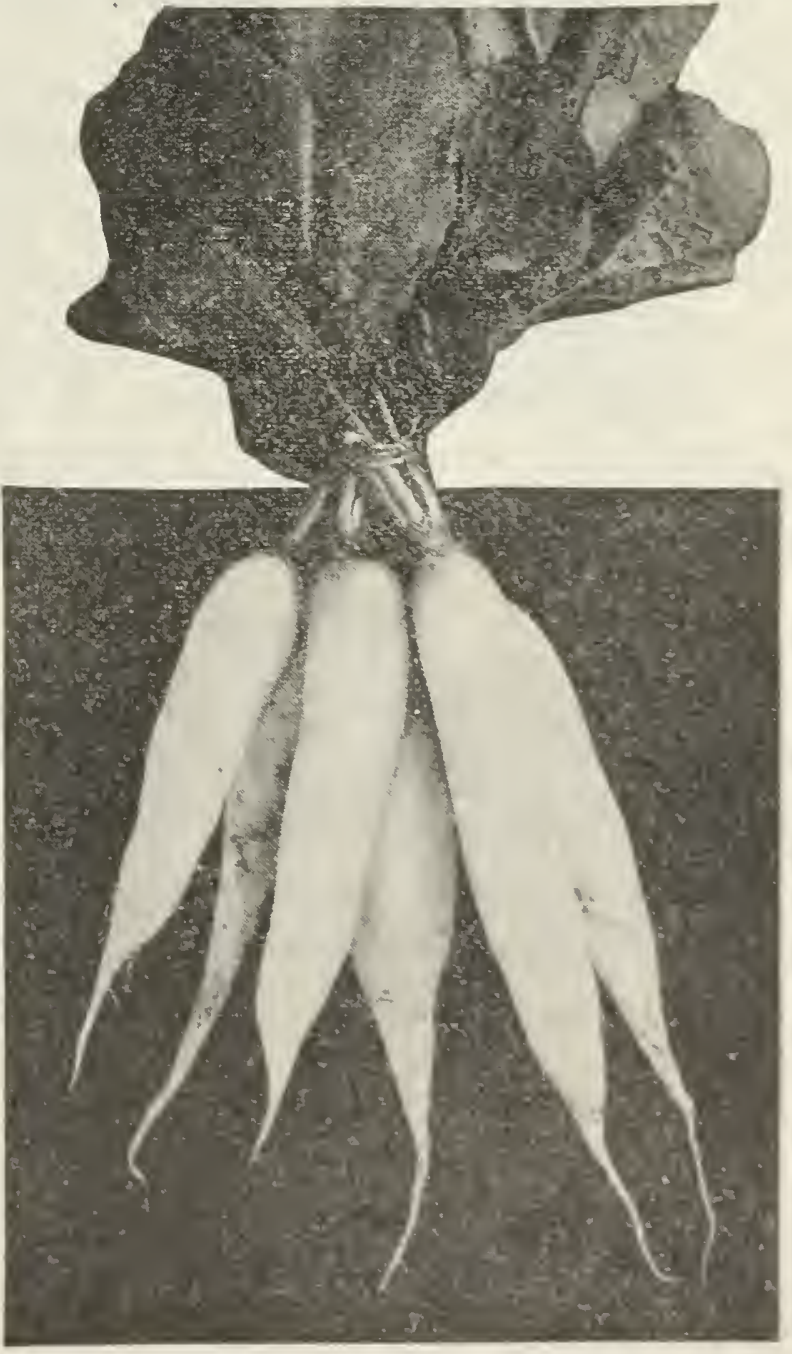

White loicte Hadishes. 


\section{Winter Radishes}

Should not be sown much before middle of July. Grow to large size and keep well for winter use. China Rose-A half long scarlet colored variety. A great favorite with the market gardeners. Pkg., 5c; oz., 10e; 1/4 1b., 35e; 1b., \$1.00, postpaid.

Long Black Spanish.-Medium size oblong black roots. Flesh pure white and very firm. Later and more hardy than most varieties. Plkg. 5c; oz., 10c; $1 / 4$ 1b., 35c; $1 \mathrm{~b} ., \$ 1.00$, postpaid.

Round Black Spanish.-Roots almost round and black. Same as the longer variety of the same nanie. Plso., 5e; oz., 10c; $1 / 4$ lb., 35e; 1b., $\$ 1.00$, postpaid.

\section{Rhubarb Seed}

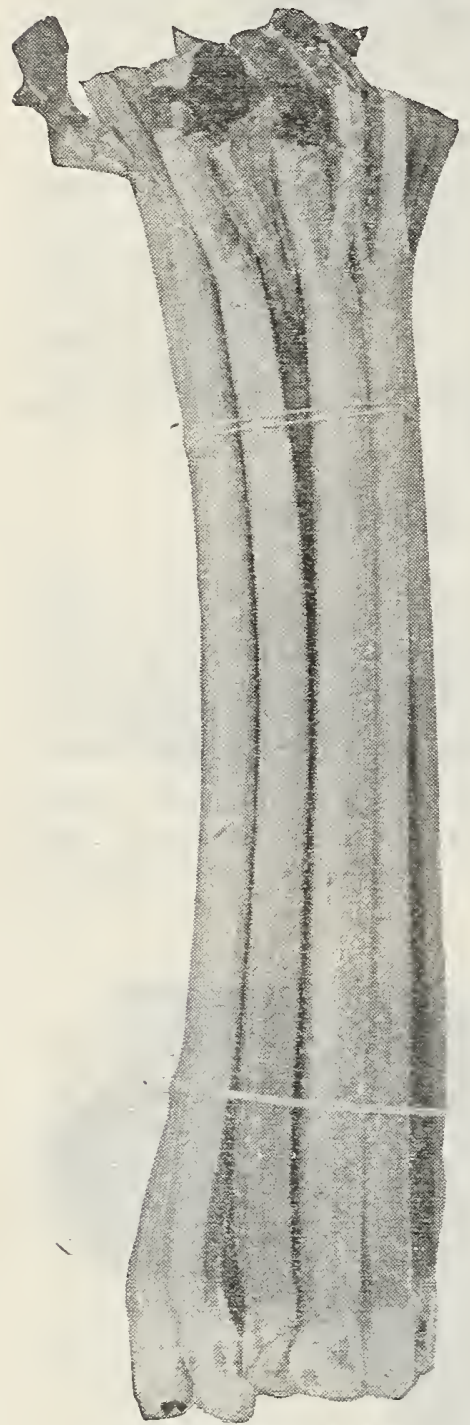

Rhubarb s e ed . Grows well in any soil. Sow seeds in rows, 18 in. apart, covered $1 / 4$ to $1 / 2$ in. deep, as early in the spring as the soil can be put in condition. Very vigorous productive and easy to raise. Pkg., 5e: oz., 15e; 1/4 1b., 40e; 1b. \$1.30, postpaid.

Rhubarb $R$ oot $\mathbf{s}$. This is, by far, the most popular way. For each root, dig a hole 6 to 8 in. deep and a foot across. In this place the root in as natural, upright position as possible. Fill in the soil gradually press it in firm contact with the roots covering the crown with 3 to 4 in of fine soil. They should be left to develop at least one year before pulling the stalks. Mailing size: Each, 20c; doz., $\$ 2.00$, postpaid. Extra large (at purchasers expense) each, 20c; doz, $\$ 2.00$.

\section{Salsify or Vegetable} Oyster

Sow seed as soon as the ground can be worked in rows, 18 to 24 in. apart. Drop 2 seeds to every inch and cover them $1 / 2$ to $3 / 4$ in. deep. Seedlings will appear in almost 10 appear
days.

Sandwich Island.- Is the stand-by in all sections. It is dug in the fall and stored like carrots or left outdoors and protected like parsnips. Pkg., 5c; oz., 3อ̃c; 1/4 1b., \$1.25; lb., \$4.00, postpaid.

\section{Spinach}

Thrives most anywhere, in all sorts of soils, but only during the cool seasons of the year. Sow seed,s in furrows, $1 / 4$ in. deep with 8 to $12 \mathrm{in.} \mathrm{between}$ the rows. Timely thinning of plants to stand 4 to 6 in apart helps in growing a quality product. In good soil, Spinach grows large enough for use in 4 to 6 weeks.

Long Standing.-The best known variety. Has large crimpled leaves of dark geen color. Very valuable variety as it stands so long without going to seed. No garden is complete without a few greens. Pkg., .̋e; oz., 10c; 1/4 1b., 25c; lb., 70c, postpaid.

\section{Sunflower}

Seed is sown early in the spring until as late as July and is a wonderful feed for chickens. It makes them lay more, giving them the shell to make eggs and does away with the eating of the eggs. It also keeps the poultry in good condition. This is the largest variety single heads sometimes measuring 15 to 22 in. in diameter. Pkg., 5c; oz., 10c: $1 / 4$ 1b., 15; 1b., 35c, postpaid.

\section{Squash}

Squash may be treated just like Pumpkins. The summer Squashes grow on upright, compact plants for which reason the hills are generally put 4 to 5 in. apart.

Yellow Bush Scallop.-A very early summer variety large size, flat with scalloped edges. Golden yellow color. Very productive with small seed cavity. Pkg., 5e; oz., 15e; 1/4 1b., 55e; 1b., \$2.00. postpaid.

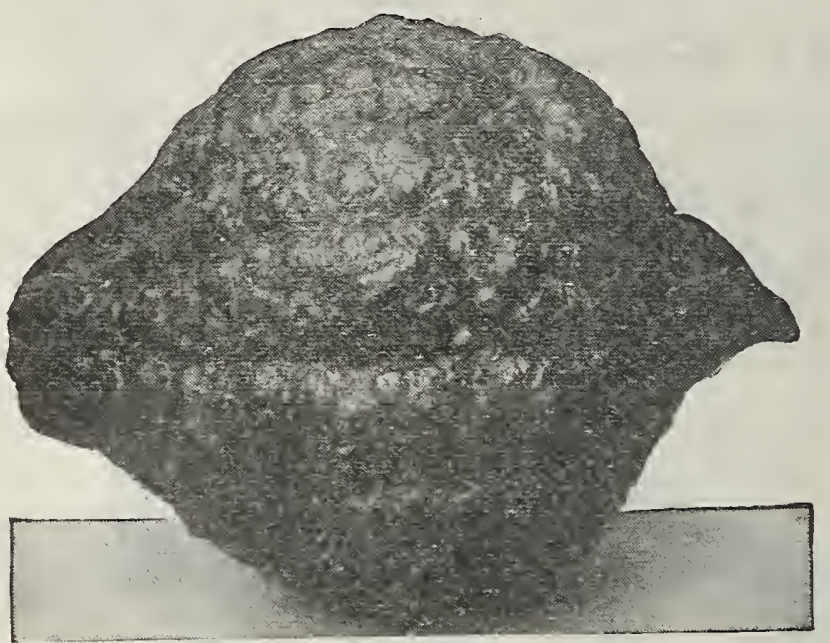

Warted Hubbard Squash.

Warted Hubbard.-The most favorite of all winter Squashes. A curiously shaped sort with dark green skin and rich orange yellow flesh. The skin is uniformly covered with small irregular lumps-hence the name. Considered the best keeper of all squashes. Very productive and hardy. Pkg., 5c: oz., 15c; $1 / 4$ lb., 55e; lb., $\$ 1.90$, postpaid.

Mammoth Bush Summer Crookneck.-This Squash differs from the other summer Squashes merely in size. Fruits measuring 20 to 24 in. long of a deep golden color. These fruits are very attractive thus being a great favorite with market gardeners. Pk., 5e; oz., 15e; 1/4 1b., 55e; lb., \$1.90, postpaid.

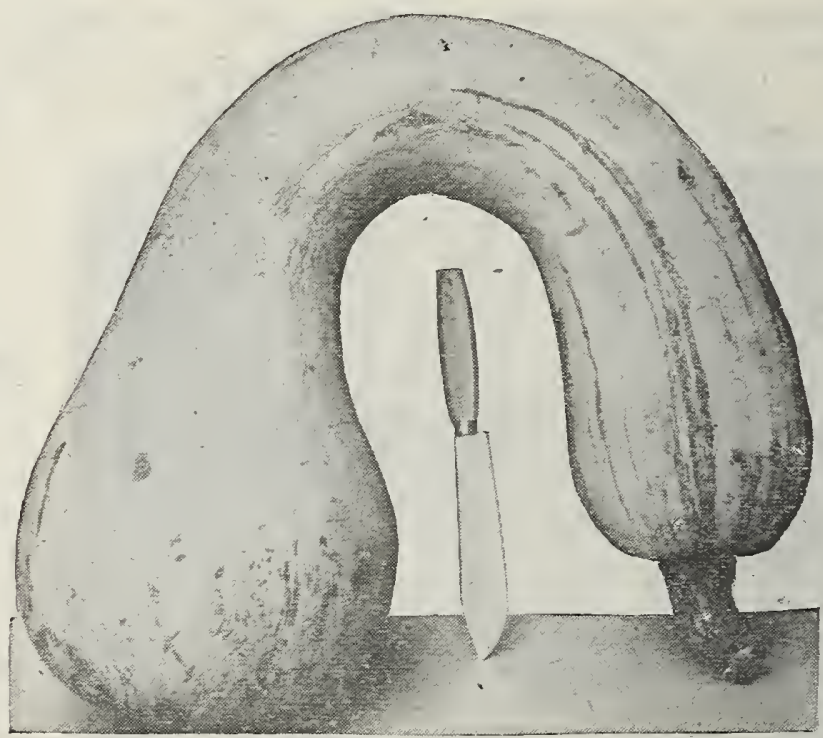

Summer Crookneck Squash.

"Golden" Hubbard.-This variety is identical with the warted Hubbard only that its color is yellow instead of green. Sometimes its skin is smooth and sometimes it is warty. Said to be the finest flavored Squash in cultivation today. Pkg., 5c; oz., I5c; 1/4 lb., 50c; $16 ., \$ 1.80$, postpaid.

Fordhook.-Very thick flesh with small seed cavity. Very prolific and an excellent keeper. Very fine grained and sweet. Pkg., 5e; oz., 15e; 1/4 1b., 55c; 1b., \$2.00, postpaid.

Mammoth Chili.-An extra large Squash of bright golden yellow color, very fine grained and sweet. Pkg., 5e; oz., 15c; 1/4 1b., 55e; 1b., \$2.00, postpaid. 


\section{Extra Select Tomato Seed}

Sow seeds any time after the middle of February in hotbeds $1 / 8$ to $1 / 4$ inch deep and keep soll molst. Seedlings will appear in 10 days. As soon as the seedlings make the second pair of leaves, transplar them into another box 4 inches apart. About the middle of May, or as soon as danger of frost is over prepare holes ins. Put a shovelful of manure in the bottom of each hole. Fill up the hole and set out the plants.

Chalk's Eurly Jewel.-This variety has taken many prizes. In 110 diays after the seeds are sown, it yields large smooth handsome fruits that average $31 \frac{11}{2}$ in. in diameter by $21 / 2$ in. deep through. average yield per plant is very high as they bear continuously. Plkg., 10c; oz., 40c; $1 / 4$ 1b., \$1.25; lb., $\$ 4.00$, postraid.

Dwarf Champion. - Is midseason, purple color maturing in 115 days. Fruits small very meaty and of exceptionally fine flavor. Very prolific. Pkg..

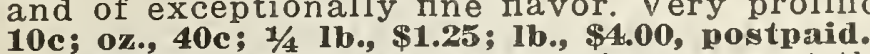

Stone.-Is the standard main crop sort throughout the country for both market and canning. As many Stone Tomatoes are grown each year as all the rest of the sorts put together. Pkg., 10c; oz., $25 c$; $1 / 4$ 1b., 75c; 16.92 .60 , postpaid.

June Pink.-Has a record of maturing fruits in 98 days after seeds are sown. Season of bearing is short. Medium size, round smooth and very solid fruits. Pkg., 10c; oz., 40c; 1/4 1b., \$1.25; 1b., \$4.00, postpaid.

Livingston Beauty.-This is the standard variety in many sections because of its adaptability to different soils and climates It matures in 115 to 120 days, fruits are flat but deep through, smooth, solid, and of uniformly good quality. Pkg., 10e: oz., 35e; $1 / 4$ 1b., 85e; $16.0 \$ 3.00$, postpaid.

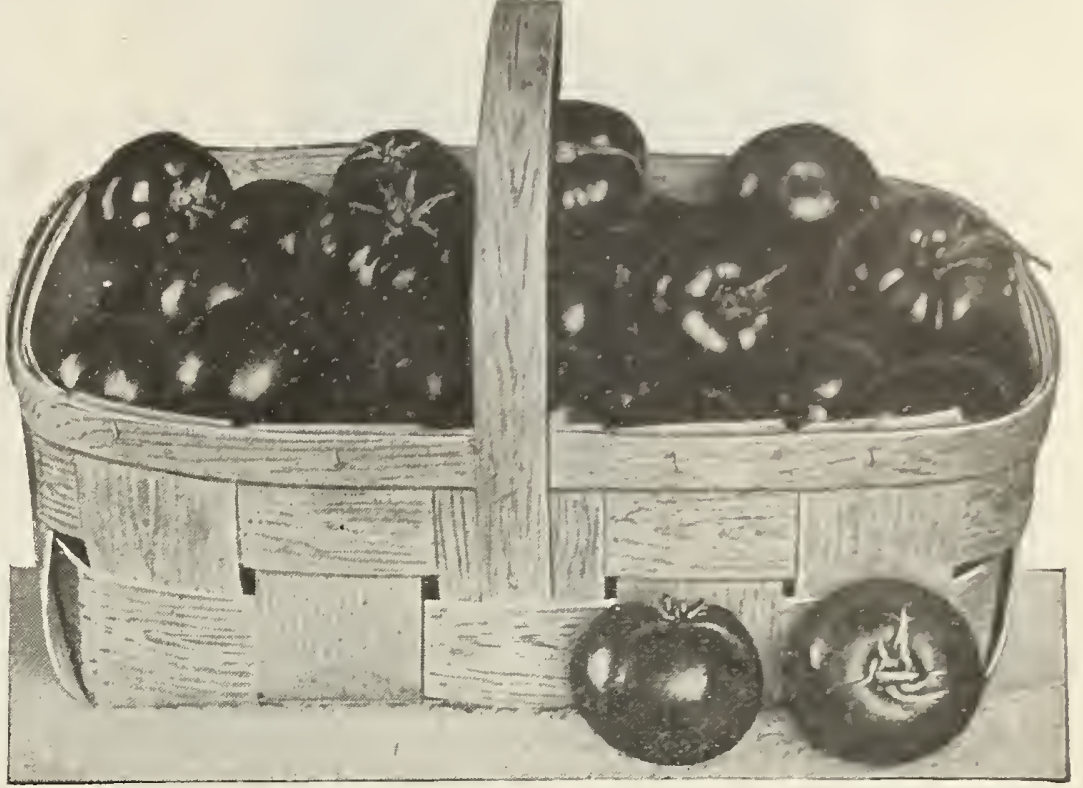

Livingston Beauty Tomato.

TOMATOES-Continued.

Ponderosa.- Is the largest Tomato. They will keep longer than most varieties as they are extremely solid. Have a rough skin, sometimes quite heavily ribbed. Pkg., 10c: 0z., 40c; 1/4 1b., $\$ 1.25 ; 1$ lb, \$4.00, postpaid.

Livingston's Globe.-This is the most pedigreed Tomato. It perfects handsome globe shaped fruits with the smoothest skin in 114 days after sowing seed,s. There is no more solid, no heavier ylelder and finer flavored tomato than this variety which seems to do well anywhere.

Spark's Earliana-This is the earliest sort on record, maturing medium-sized fruits in 100 days. Its season of bearing is short and the flavor is decidedly acid. Pkg., 10c; oz., 40c; $1 / 4$ 1b., \$1.25; 1 b. $\$ 4.00$, postpaid.

Acme--Produces dark red smooth fruits of medium size and bears continuously until cut off by the frost. Very solid and juicy fruits, excellent for canning. Pkg., 10e; oz., 35e; 1/4 1b., 85e; 1b., \$3.00, postpaid.

Yellow Plum.--Small plum shaped yellow fruits used especially for pickles and preserves. Pkg., 10e oz., 40c; $1 / 4$ lb., $\$ 1.30$; 1 b., $\$ 4.50$, postpaid.

Yellow Pear.-Same as the plum only pear shaped and smaller fruits used, for the same purposes as the plum. Pkg., 10c; oz., 40c; 1/4 1b., \$1.30 1b., \$4.50, postpaid.

\section{Turnips}

Sow seed very thinly, on an average of not more than 2 to an inch. The roots should be placed 12 to 24 in. apart, according to variety. Cover seed from $1 / 4$ to $1 / 2$ in, deep. As soon as seedlings are 2 to 3 in. high thin them out After the young plants outgrow the baby stage, they become healthy, rugged weeds and require little attention except that they should be hoed about once a week.

DON'T Spoil your chance of having a good garden this yenr by forgetting to order your secds until it is too late. DO IT Now.

Purple White Globe.-Forms handsome, globe shaped roots in 75 to 80 days from date seeds wer sown. Properly grown roots average 3 to $31 / 2$ in. in diameter and have pure white skin with red and purplish blotches around the top. A fine table variety and an excellent keeper. Pkg. 5c; oz., 15c $1 / 4$ 1b., 40c; 1b., \$1.25, postpaid.

Golden Ball.-An excellent variety for winter use. The outer skin is yellow and the flesh is a is adapted to spring as well as fall planting. Pkg. Бc; oz., 15c. acre.

One ounce of good seed in mumcient for an Pkt., 5c: oz., 35e.

\section{Tobacco}




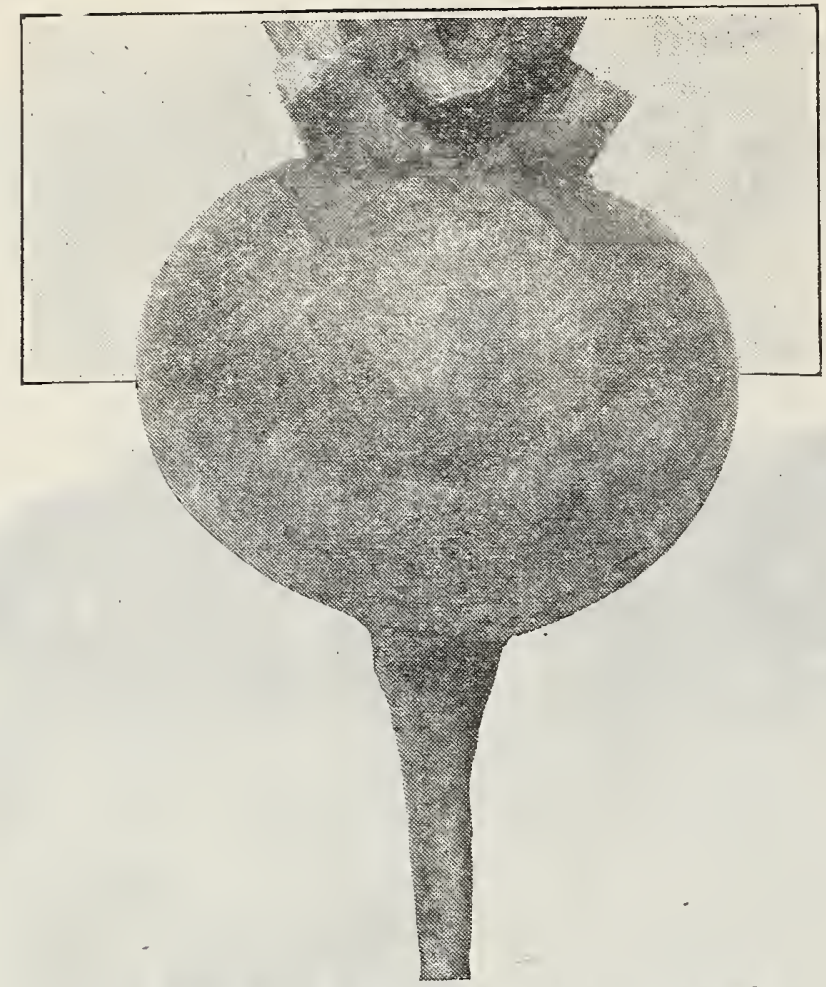

Purple Top Strap Leaved Turnip.

Purple Top, strap-Leaved.-The same specimen of Turnip as the White Globe only it is flat instead of round. The purplish blotches above the ground and the balance of the root underneath the ground is pure white. A very tender and fine grained sort. Pkg., 5c; oz., 15e; 1/4 1b., 40c; Ib., \$1.25, postpiaid.

\section{Our 50c Collection}

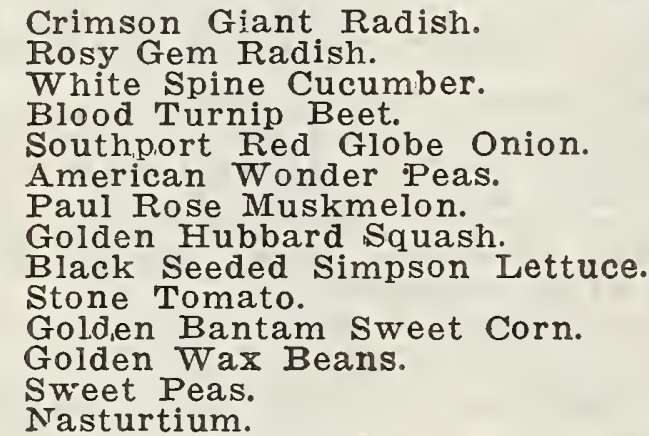

75. CENTS WORTH OF SEED FOR 50 CENTS

\section{Our $\$ 1.50$ Collection}

1. Golden Wax Beans.

2. Wardwell's Wax Beans.

Eclipse Beet.

All Seasons Cabbage.

Oxheart Carrot.

White Plume Celery.

Green Cluster Cucumber

Long Green Cucumber.

Tilton's White Star Lettuce.

Kleckley Sweets Watermelon.

Rockyford Muskmelon.

Netted Gem Muskmelon.

Yellow Danver Onion.

Red Wethersfield Onion.

Guernsey Parsnip.

First \& Best Peas.

Abundance Peas.

Parsley.

Ruby King Peppers.

Sugar Pumpkin.

French Breakfast Radish.

White Icicle Radish.

Crimson Giant Radish.

Warted Hubbard Squash.

Fordhook Squash.

Livingston Globe Tomato.

Earlibell Tomato.

White Globe Turnip.

Prize Winner Rutabaga.

Pansy.

Sweet Peas (2 pkgs.)

Nasturtiums (2 pkgs.)

3. Aster.

34. Petunia

\section{Rutabaga}

These differ from the common turnips in having more of a cabbage like foliage and the roots grow to a much larger size, besides being by far the best keepers.

American Purple Top.- Is the leading kind and is very fine table variety. Purple tops grow partly out of the ground, being of a bright yellow color beneath the soil. It is of elongated globe shape. Flesh yellow. Pkg., 5c; oz., 15c; 1/4 1b., 40c; Ib., \$1.25, postpaid.

Prize Winner Rutabaga.-A very short necked, hence easily harvested variety producing very large round yellow roots. An excellent winter variety. Pkg., 5e; oz., 15e; 1/4 oz., 40c; 1b., \$1.25, postpaid.

\section{Our $\$ 2.00$ Collection}

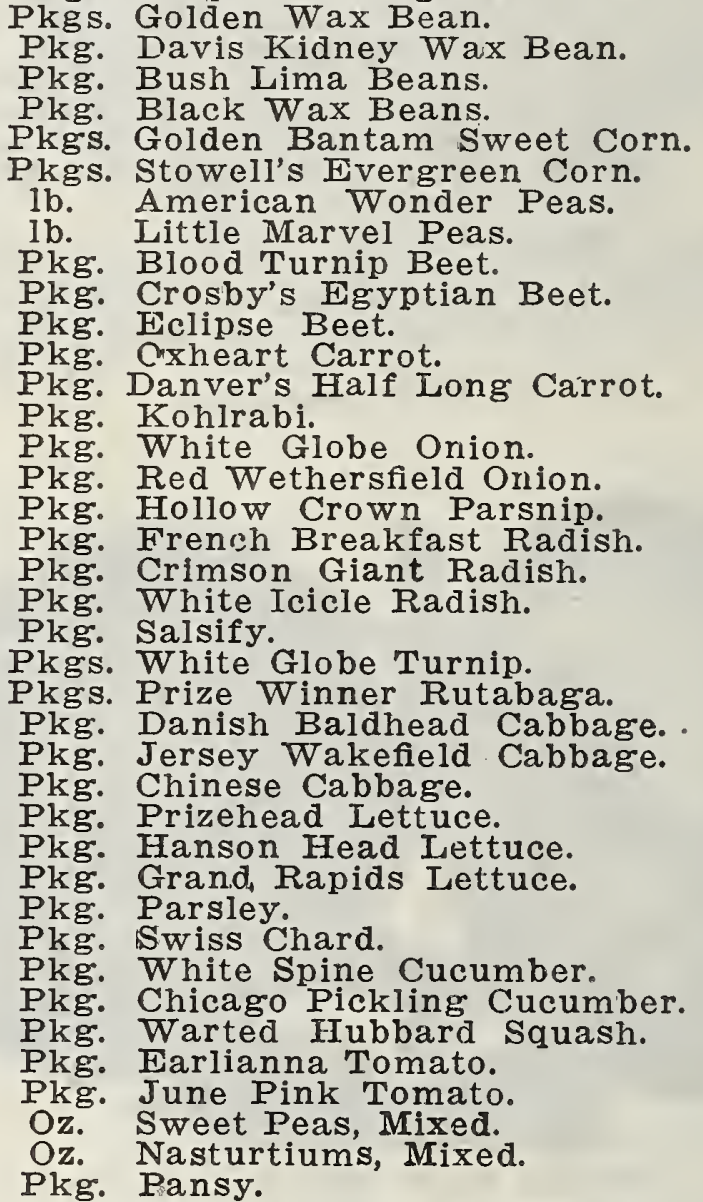

These collections are put up in advance and are sold at a greatly reduced price and there can be no changes in the varieties. Premiums do not apply to these collections as they are premiums in themselves.

\section{Our $\$ 1.00$ Flower Seed Collection}

1 Oz. Mixed Sweet Peas.

1. Oz. Dwarf Mixed Nasturtiums.

1 Pkg. Pansy.

1 Pkg. Asters.

1 Pkg. Petunia.

1 Pkg. Poppy.

1 Pkg. Phlox.

1 Pkg. Morning Glory.

1 Pkg. Carnation.

1 Pkg. Sweet William.

1 Pkg. Cosmos.

1 Pkg. Candytuft.

1 Pkg. Mignonette.

1 Pkg. Daisy.

1 Pkg. Bachelor Buttons.

1 Pkg. Sweet Alyssum.

1 Pkg. Hollyhock.

1 Pkg. Marigold.

1 Plig. Zinnia.

1 Pkg. Verbena.

$\$ 1.50$ WORTH OF SEED FOR $\$ 1.00$ 


\section{FLOWER SEEDS}

On the following pages we offer the best varieties of eholce Flower Secds. Our seeds are frewh nna of unsurpassed quality, grown by the best growers in this country and Lurope. (2uality is always our first consideration. There is no space so small that there is not room for a few of these beantiful fowrers, and with a small outlay a succession and abundance of bloom can be obtained. Our jackets contaln liberal quantity of seed, more than is senerally sent out by other firm. ANNUALS bloom rand ripen the seed the first rear and then perish. PERENNIALS continue flowering for several gearm In wucewsion. Mang of them bloom the first year.

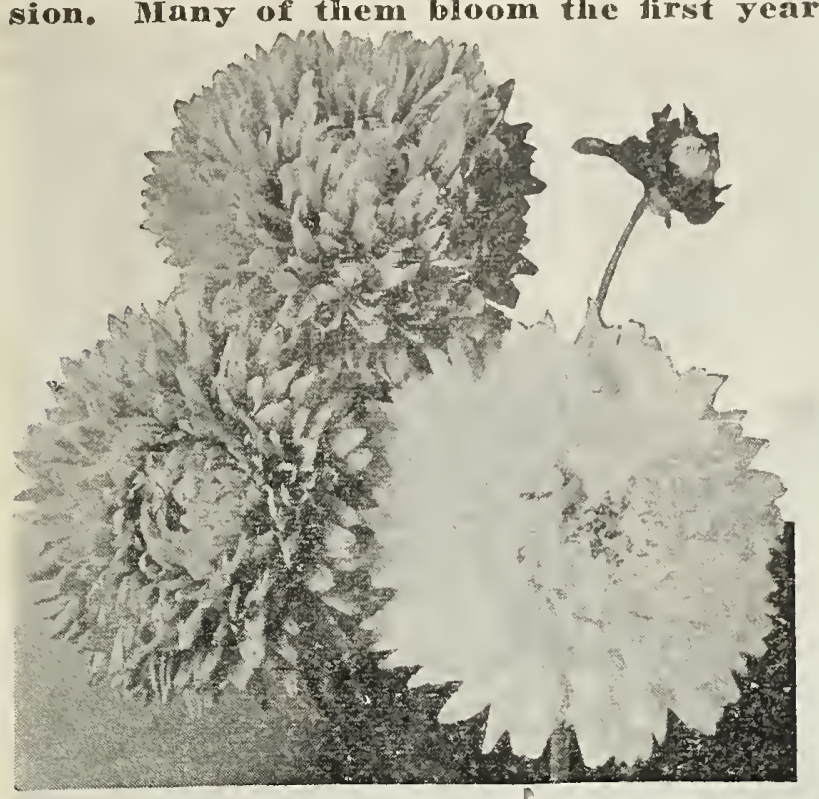

Asters.

Sweet Alyssum.-Especially desirable for a border plant. This little flower blooms all summer, is pure white and grows only about or 3 in. high. Very sweetly scented. Per pkg., 5e.

Balsam or Lady Slipper.-Seeds can be sown as soon as danger of frost is over. Must have the hot frost is over. Must have the well. Sun and plenty of water to do well. colored blossoms. Mixed Colors, per pkg. Бc.

Amaranthus.-Very b r ig h t colored with exceptionally heavy foliage making it an ideal flower for bordering tall flowers. Set plants 20 in. apart as they must have plenty of room. Per pkg. 5c. Caudatus (Love Lies Bleeding).Long, drooping scarlet flowers;
plant grows about 3 feet tall. Pkg. 5c.

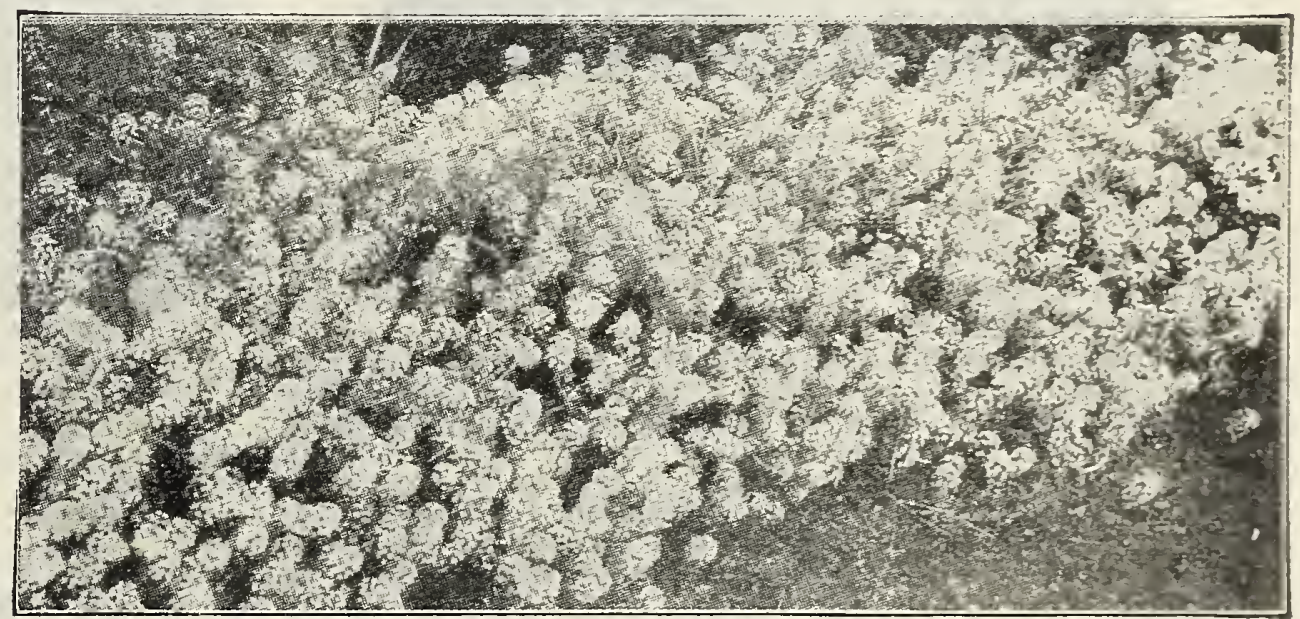

Sweet Alyssum.

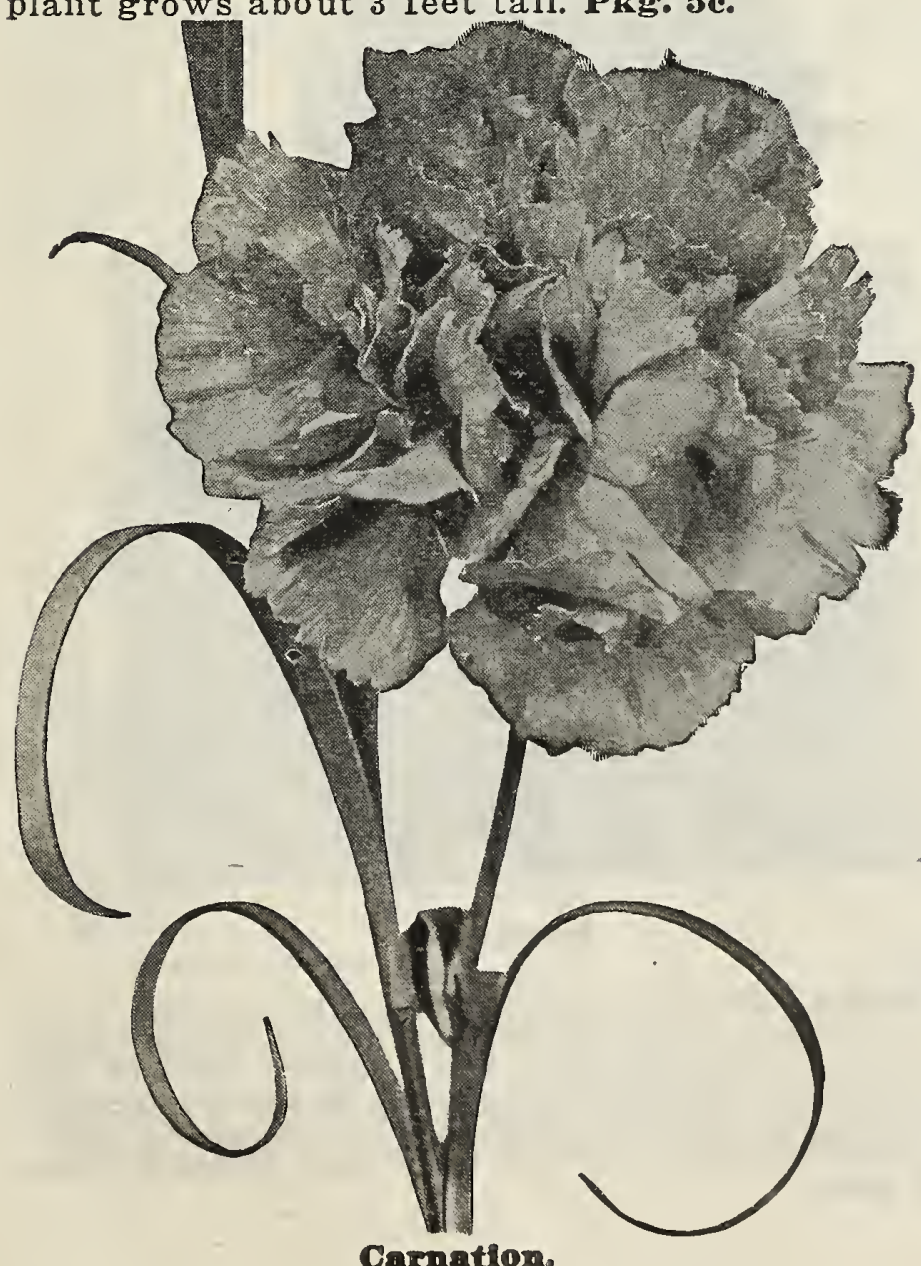

Asters.-One of the most popular of all annual flowers. ( easily cultivated as it requires only moderately rich care. As the Asonable amount of moisture and very little the seeds in May and transplant.

Peony Flowered Perfection Aster.-True to name its flowers resemble the peony. Produces double almost round blossoms measuring 4 to 5 in. across. The plants are large and stems very long and strong. Blue, 10e; Crimson, 10es Mixed Colors, 10c, per pkg.

Giant Comet Asters.-This variety of Aster resembles the Chrysanthemum, having long curled petals which give it that-fluffy appearance. Plants are very large and upright bearing from 20 to 25 flowers. An excellent variety for a cut flower as they remain in good condition so long after cutting. Dark Blue, 10c; Rose Pink, 10c; Crimson, 10c: Mixed Colors, 10c; White Rose, 10e; White Striped with Pink, 10c, per pkg. 


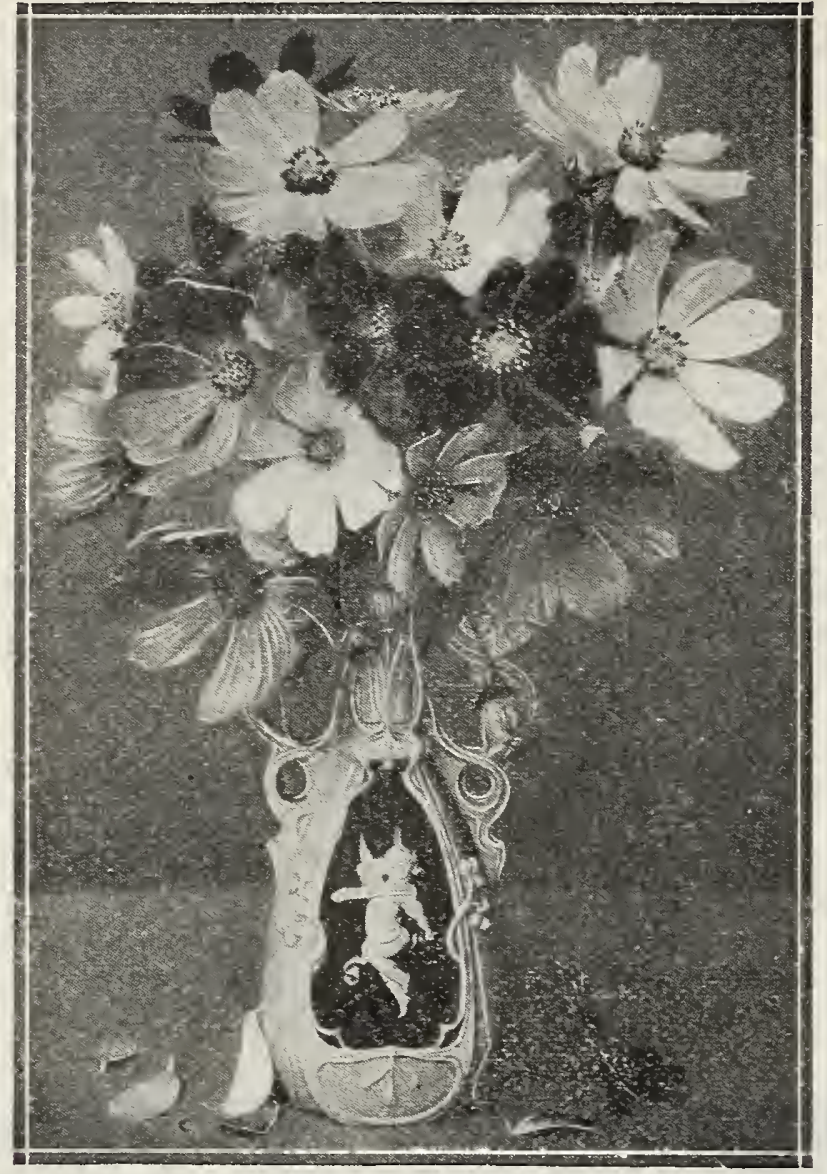

Cosmos.

Ricinus, Castor Oil Bean.-Grown for their extremely picturesque foliage. Form brilliant colored seed pods which harmonize beautifully with the dark green leaves. Very fine as center plants for a bed. Per pkg., 5c.

Chrysanthemum.-One of the most beautiful of all annual flowers. This variety is especially desirable as it will produce large blossoms from seed and bloom continuously until frost. Very seng stems and blossoms will keep a week or 10 days after cutting. Plants grow to the height of diys after cutting. Plants grow to the height of $11 / 2$ ft. Single Mixed Colors, 5e; Mixed Colors Douper pkg.

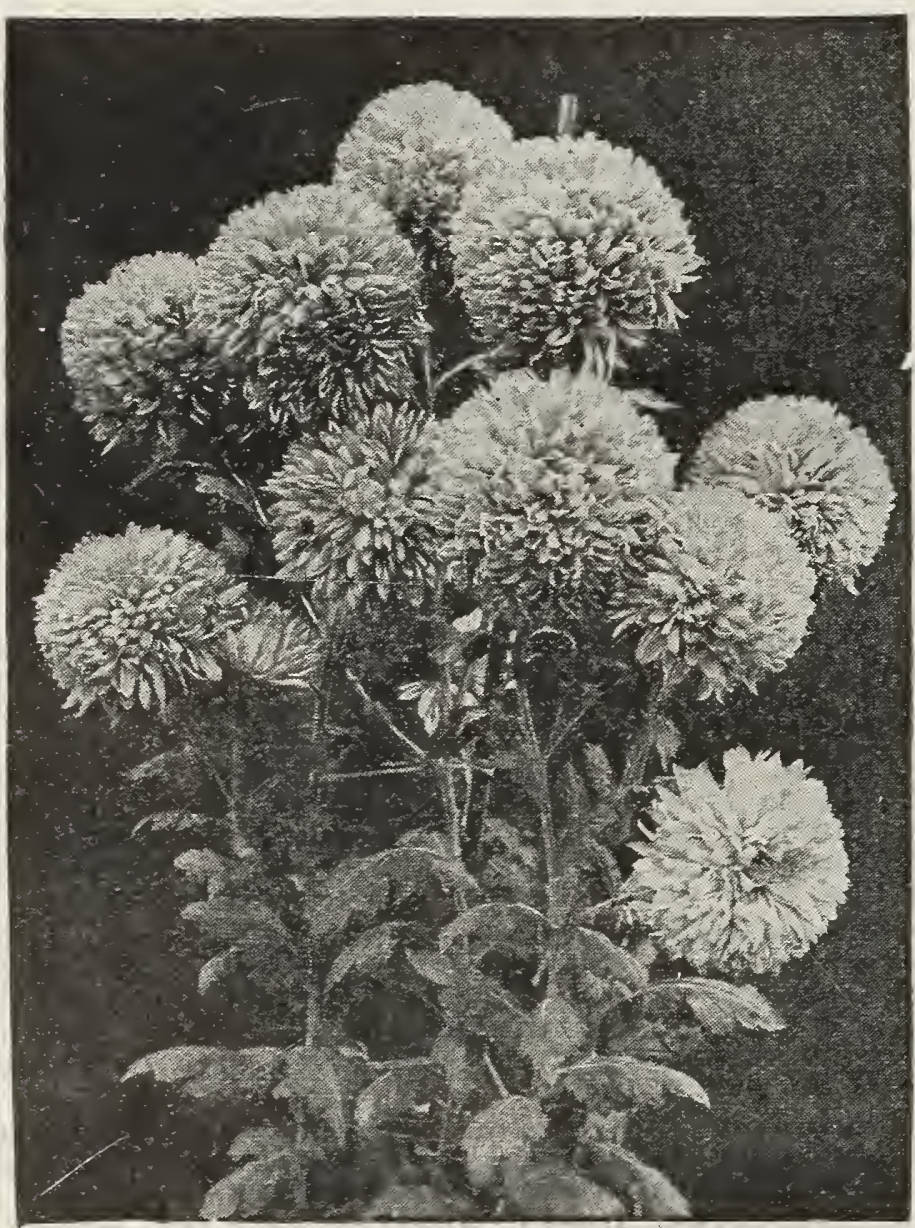

Chrysanthemum.

Cosmos.-One of the most popular flowers on account of the ease with which it is grown. Grows 3 to 4 feet high producing flowers resembling the single Dahlia. Exceptionally long stems and keeps a long time in winter.

Early Flowering Dawn.-Producing plants $4 \mathrm{ft}$. high in full bloom in 2 months from time seeds ar $\theta$ sown. Very prolific, bearing beautiful rose, purple and white shades of blossoms until frost. Pex pkg. 5c.

Lady Lenox.-An extra large variety of Cosmos producing blossoms 6 in. in diameter of all shades of pink. Per pkg. 5c.

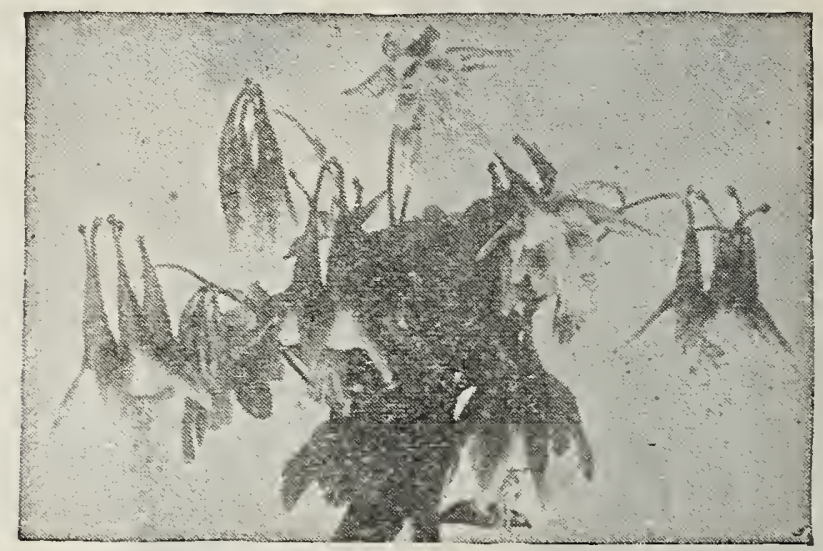

Columbine.

Columbine-Blooms early in the Spring producing plants 1 to 3 ft. high. The magnificent array of colors makes it one of the showiest and most desirable of all garden flowers. Is very hardy and will do well in a partially shaded place. Varie. gated, colors. Perennial. Pex pkg. J̌c

Catchfly.-A showy, free-flowering plant, with bright, dense heads of flowers, growing well in common garden soil. Adapted for borders, circular beds and ribbons. Height, 18 inches. Hardy annual. Pkg., 5e.

Cypress Vine.-A very rapid growing vine with finely cut dark green leaves with rose pink and white star shaped blossoms. Per pkg., 5c.

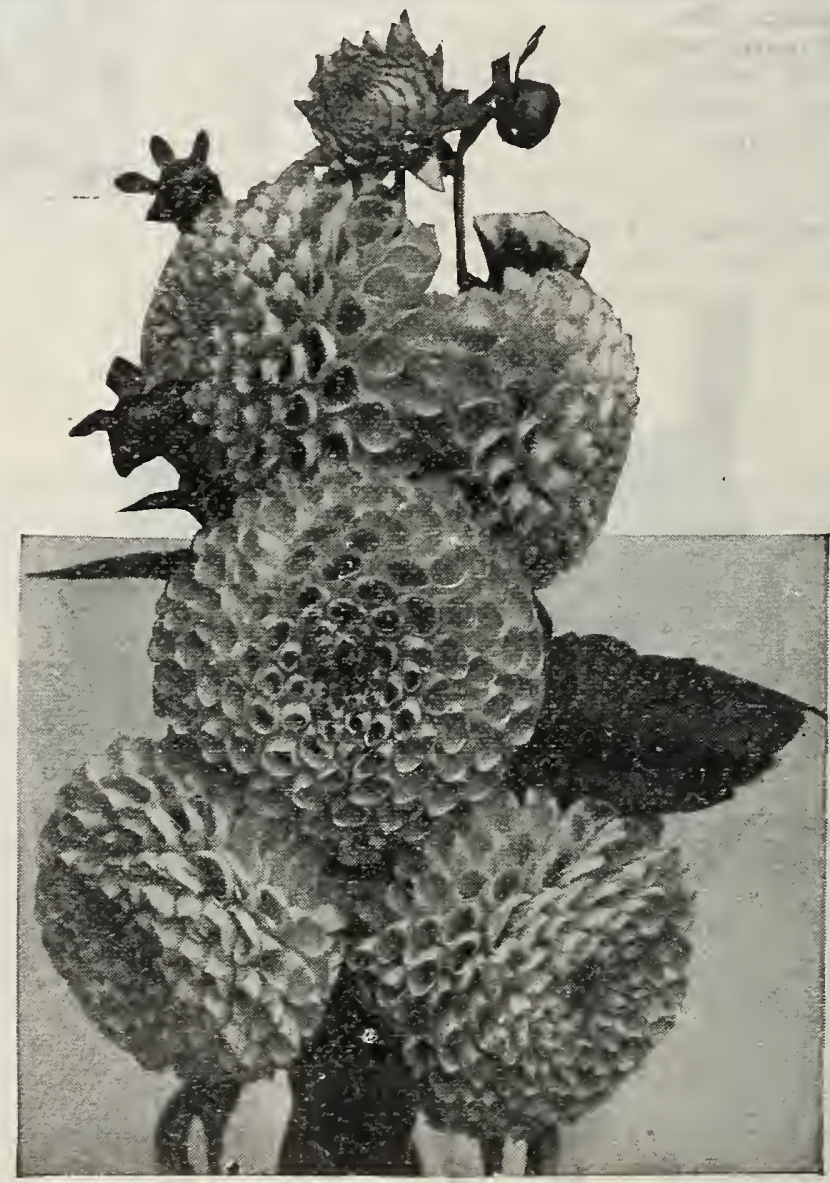

Dahlias.

Dahlia.-One of the most beautiful garden flowers, comprising every color imaginable, except blue. Can be grown from seed and produce flowers the first year. Very desirable as a cut flower on account of its brilliant coloring and, excellent keeping qual. ities. Double Mired Colors, 5e; Single Mrixed Colors, sc per pkg. 
Dianthus or Pinks.-Grows about 12 in. high producing blossoms in all shades of pink, white and red which are very sweetly scented. Sow seed outdoors as soon as weather conditions are favorable and in a very few weeks they are a mass of flowers. Double Annual Mixed, Single Annual Mixed, Hardy Garden Mixed, sc per pkg.

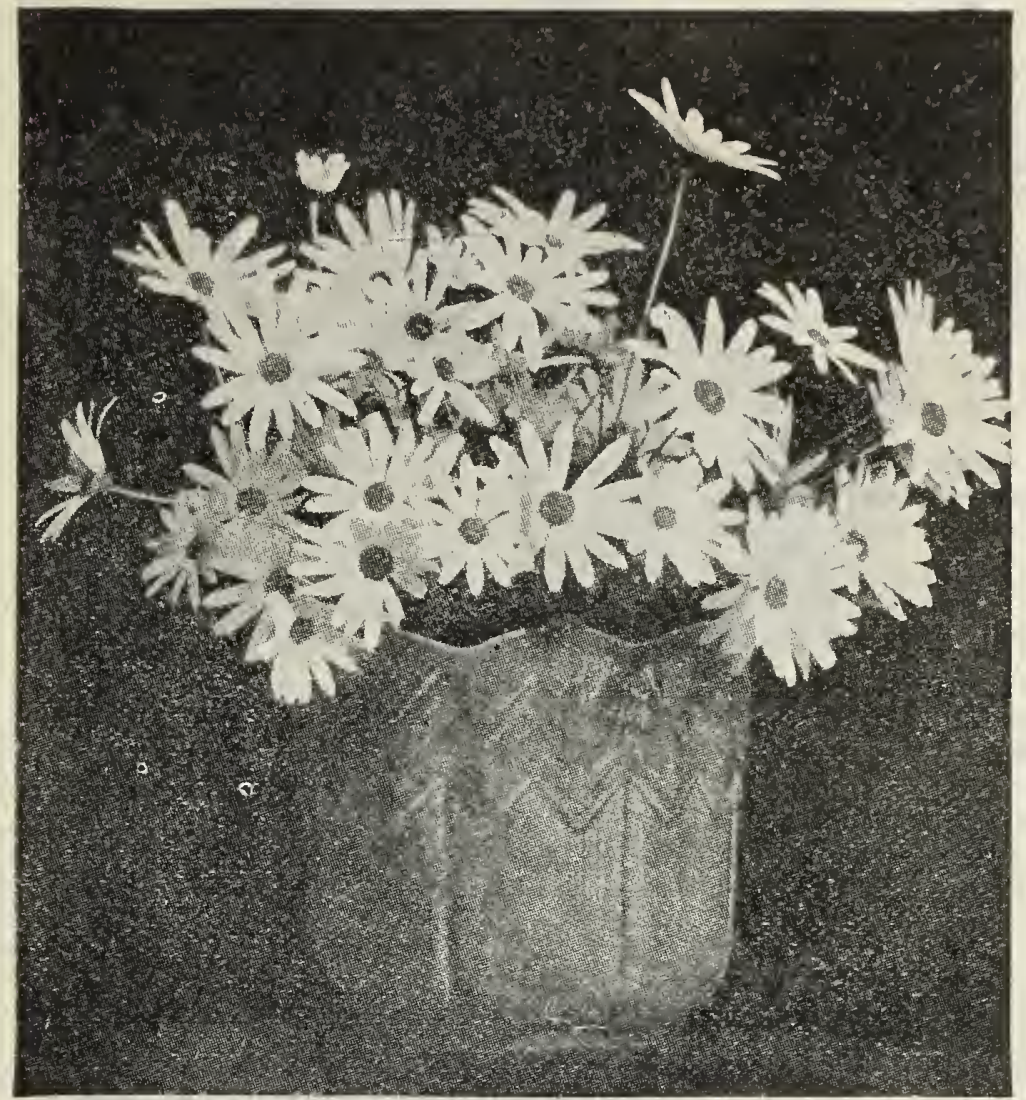

Daisies.

Daisies.-Grow to the height of 6 in. Very handsome as a border plant blooming from seed the first year. Best Double Mixed Colors, 5c per pkg.

New Giant Snowball. - A variety of Daisy, pure white, large double blossoms on extremely lon stems. Very valuable for cutting. Per pkg., 5c.

Daisy (Shasta) - A single variety of Daisy pure white blossoms growing 3 to 4 in. in diameter. Bloom entire season. Perennial. Per pkg., 5c.

Datura. Angel's Trumpet.-Plants growing $5 \mathrm{ft}$. producing very large trumpet shaped flowers resembling the Morning Glory and very fragrant. Double Mixed Colors, 5c per pkg.

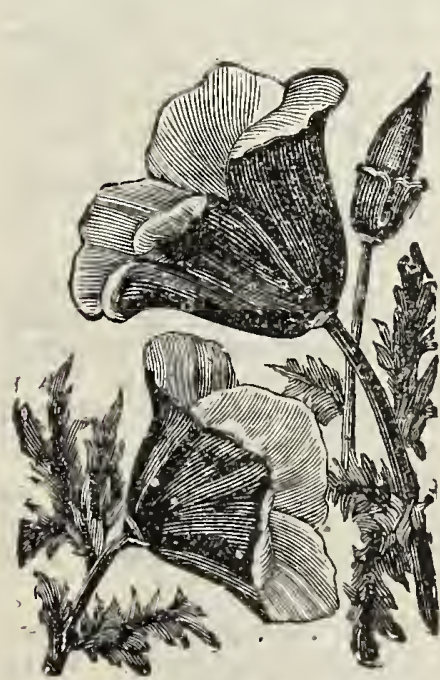

Eschscholtzia. California Poppy.-A w e 11 known favorite, commonly called California Poppy. A very hardy and easily grown producing large grown producing large coloring. Annual. Golden West: Bright $Y$ ello w blended with orange, per pkg. Hose Cardinal. Bright red blended with pink, 5c per pkg.

Forget-me-not.-A beautiful small flower blooming from seed the first year. Will blossom the following spring if given a slight protection during the cold months. Thrives best in a moist and shady location. Very fine for a border plant. Nothing makes a

Eschscholtzia.

prettier border than a combination of blue forgetme-nots and pure white sweet alyssum.

Alpestris Coerulea: Bright Blue, 10c per pkg. Alpestris, Mixed: White, red and blue, $10 \mathrm{c}$ per pkg.

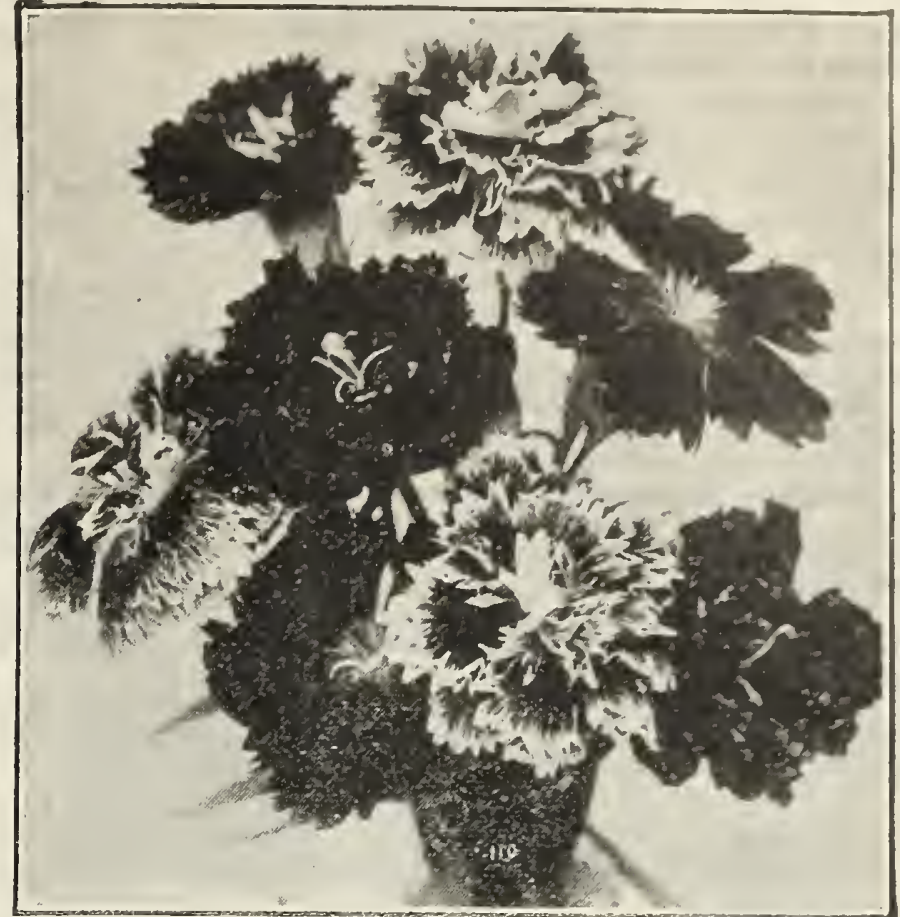

Dianthus.

Four o'Clocks. - As the name implies the blossoms do not open until four o'clock and die the following morning. Flowers, in all shades resemble the morning glory only the blossoms are conft. high. These bushes make an exceptionally fine hedge. Per pkg., 5c.

Foxglove.-Very hardy producing large spikes of highly colored blossoms. Per pkg., 5c.

Geranium.-These flowers can very easily be grown from seed, and blossom the first year but they must be planted as soon as the ground, is warm enough to do so. Mixed Colors, per pkg., 10c.

Gourds. Ornamental.-If you want a very quick vine with dense foliage sow this variety. It produces very peculiarly shaped fruits both useful as well as ornamental. Per pkg., 5c.

Ornamental Grasses.-Produces a very feathery plant which is used a great deal in with cut flowers in bouquets, etc. Also used in weaving baskets and other crnaments. Per pkg., 5c.

Gypsophila. (Baby's Breath)-A very beautiful plant producing small star shaped, pure white flowers borne on very long stems. Very fine for bouquets. Annual. Per pkg., 5c.

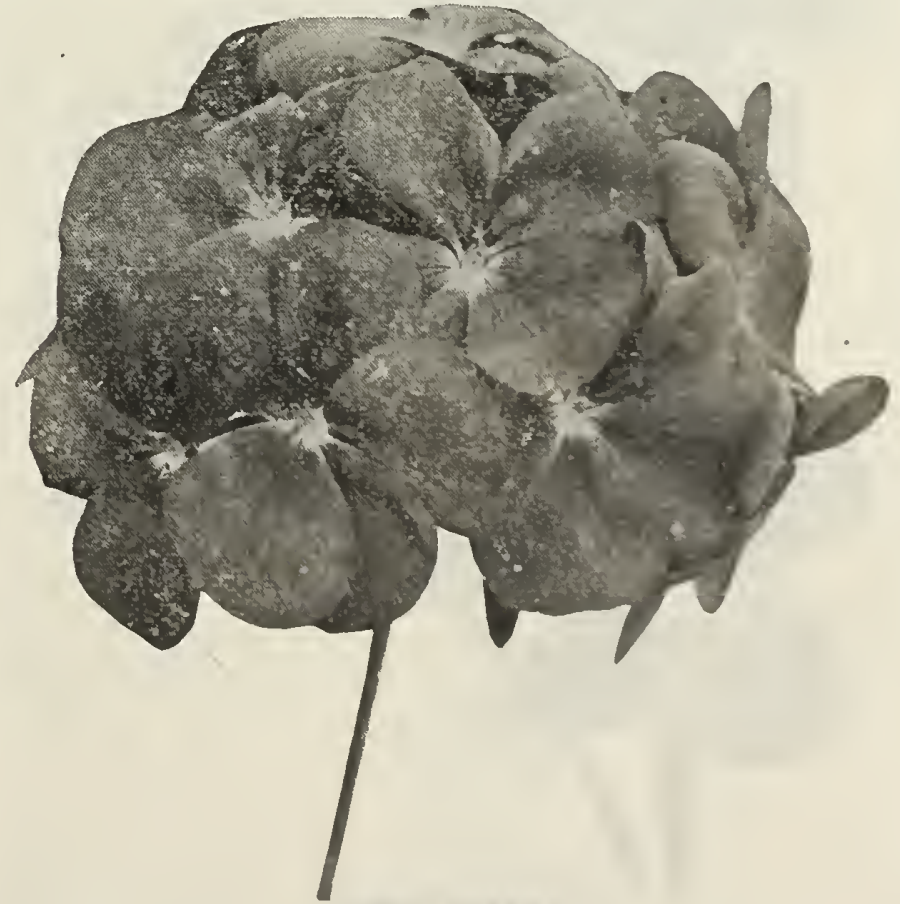

Geranium. 
Heliotrope.-One of the most fragrant flowers in cultivation. Plants 12 in. high and easily grown from seed, blossoming the first year. Flowers deep purple and borne in clusters. Perennial. Mixed Colors, per pkg., 5c.

Hollyhock-One of the most favorite and easily grown of all flowers. Produces large double flowers of every shade, on long spikes. Exceptionally fine for a border plant. Perennial. Double White, 10c: Double Pink, 10e; Yellow, 10c; Red, 10e; Mixed Colors, 10e per pke.

Hollyhocks, Everblooming Annual.-A mixed variety of this plant growing 5 to $8 \mathrm{ft}$. in height and blooming until frost. Sow seeds in. side in March and set out in May. Per pkg., 10c.

Hop (Variegated Japanese)-One of the most beautiful climbers growing $20 \mathrm{ft}$. high with leaves distinctly mottied with silvery white, yellowish white, and light and dark green. Per pkg., 5e.

Ice Plant (Mesembryanthemum) - A very fine basket plant producing plants with leaves that seem to be covered with ice crystals and pure white flowers. Per pks;., 5c.

Kochia. Summer Cypress or Mexican Fire Bush.-A fine plant for hedge. Grows about $3 \mathrm{ft}$. high and is of a bright green color until autumn when it turns a beautiful shade of red. Of rounded form with very fine foliage and stems. Per pkg., 5c.

Lupins. Annual Mixed.-Very fragrant producing its bright colored flowers on long spikes. Good bedding variety and does well in a partially shaded place. Per pkg., 5c.

Lychnis.-An exceptionally fine border plant producing very bright flowers and blossoming the first year if planted, real early. Requires rich soil. Perennial. Per pkg., 5c.

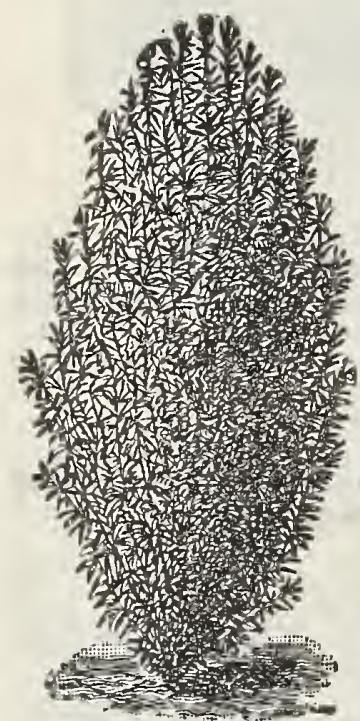

Iochia.

Moonflower.-A very rapid climbing plant sometimes attaining the height of $40 \mathrm{ft}$. At night these vines are covered with pure white tunnel shaped wax like blossoms which close about noon the following day. Its very dense foliage makes it especially desirable where shade is needed. Per pkg., 10 e.

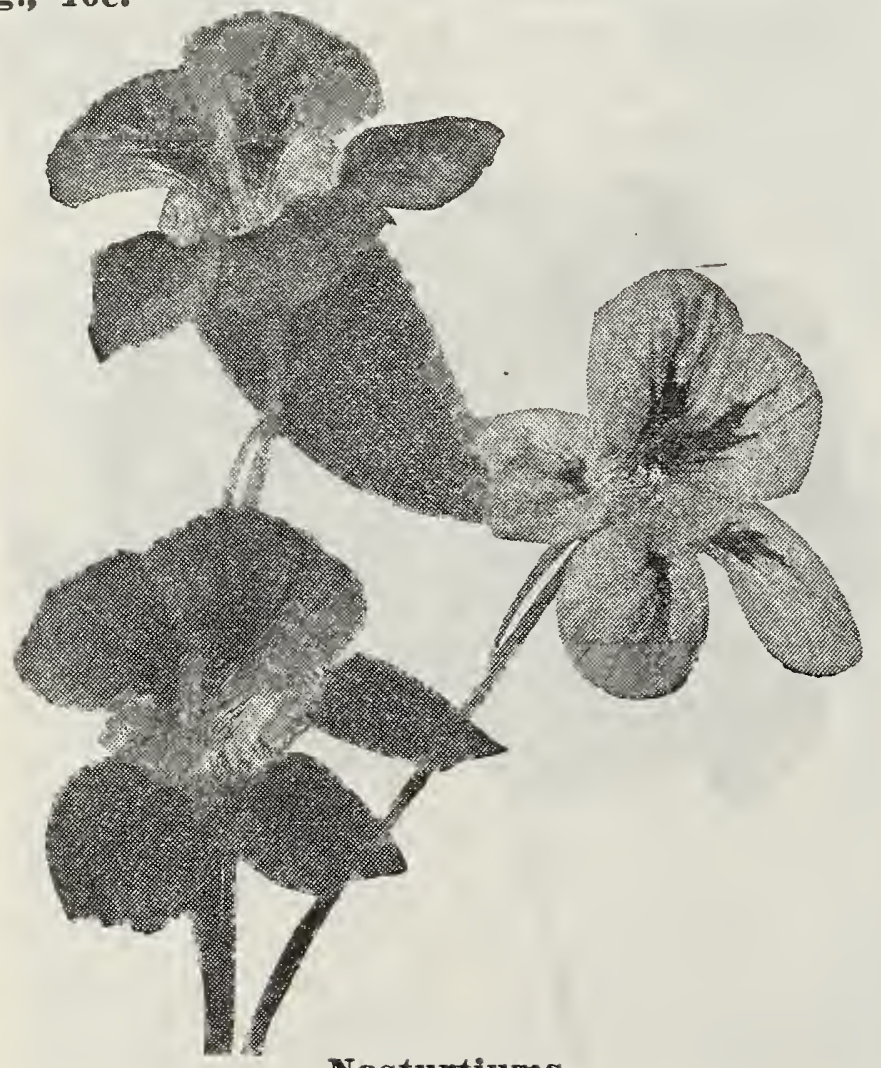

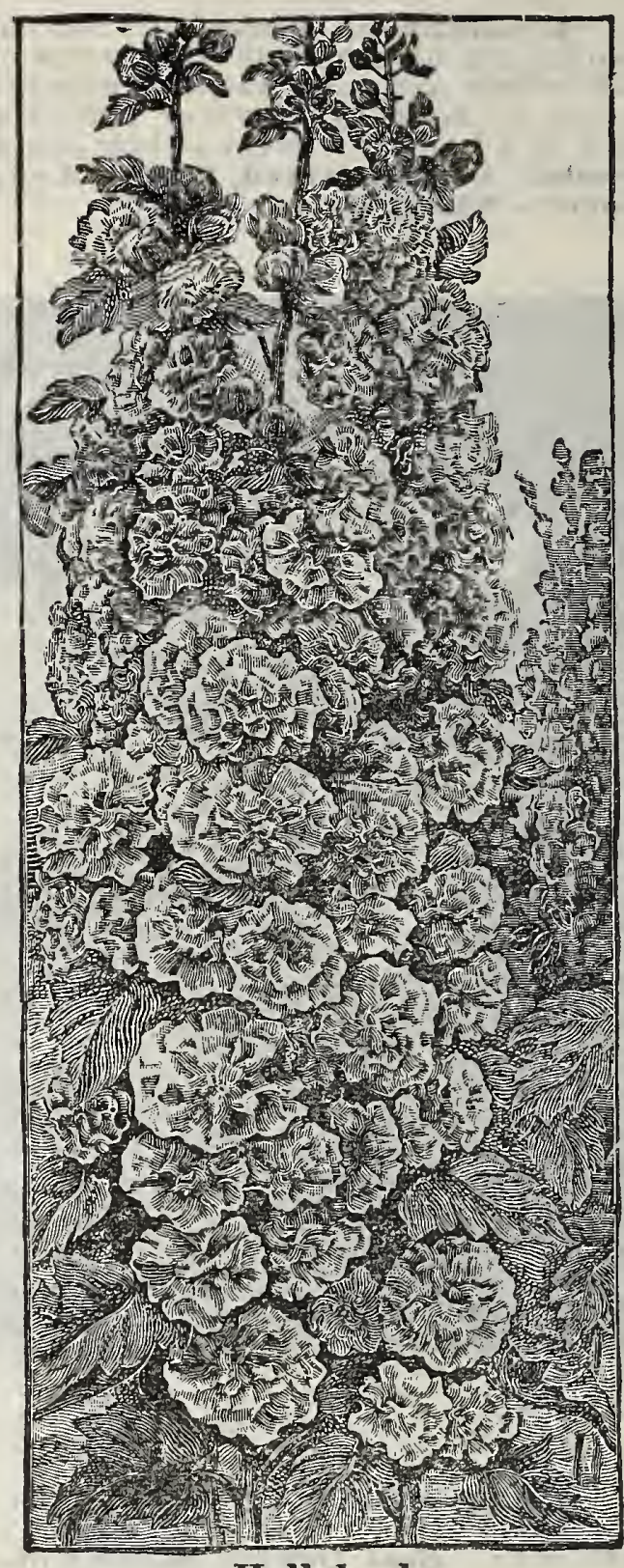

Hollyhocks.

Imperial Japanese Morning Glory.-Rapid growing climbers producing Giant flowers in white, pink and blue. Seed should, be sown as early as possible and must have plenty of moisture and sun No garden is complete without a few Morning Glories. Per pkg., 5c.

Convolvulus.- The well known old fashioned variety of Morning Glory. Thrives under almost any condition. Per pkg.

Fine Mixed.-All colors and varieties mixed, 5c.

Nasturtiums, Dwarf or Bedding.-One of the most popular of all border plants. Plants grow in bushes about one foot high and, produce a profusion of velvet-like blossoms comprising all the various shades of yellow, red and brown. Plants will do best if soil is not too rich. Per pkg., 5e; oz., 15e.

Tall or Climbing.-Flowers are the same shades as the Dwarf but not as large. Very fine for verandas. Per pkg., 5c; oz., 15c.

Portulaca or Moss Rose.-Very small plants exceptionally fine for borders producing waxy leaves and brilliant colored flowers of all shades. They thrive best in rich sandy soil and must have a great deal of sun. Per pkg., 10e single mired; 10c double mixed.

Parana.-The single blossoming type of Portulaca from South America. Has extremely large blossoms of only one color, namely, red. Per pkg., 10c.

Oxalis.-Grow about 6 in. high producing clover like foliage and small bright colored, flowers. Very fine for baskets or pot plants. Per pkg., 5c.

Oenothera. Evening Primrose. -A low growing, very tender plant with large white, rose and yellow blossoms. Will thrive in most any kind of soil. Per pkg., 10c. 
Loebs Mixed Royal Show Pansles.-Everyone is acquainted with this flower, therefore it needs no description. In order to produce a good bed the seed should be started indoors in February or March. This special variety comprises all the best separate colors known and is, therefore positively the best assortment in Pansies that can be bought. Per pkğ., 10c.

Imperial.-Highly colored flowers exceptionally large. Per pkg.., 10c.

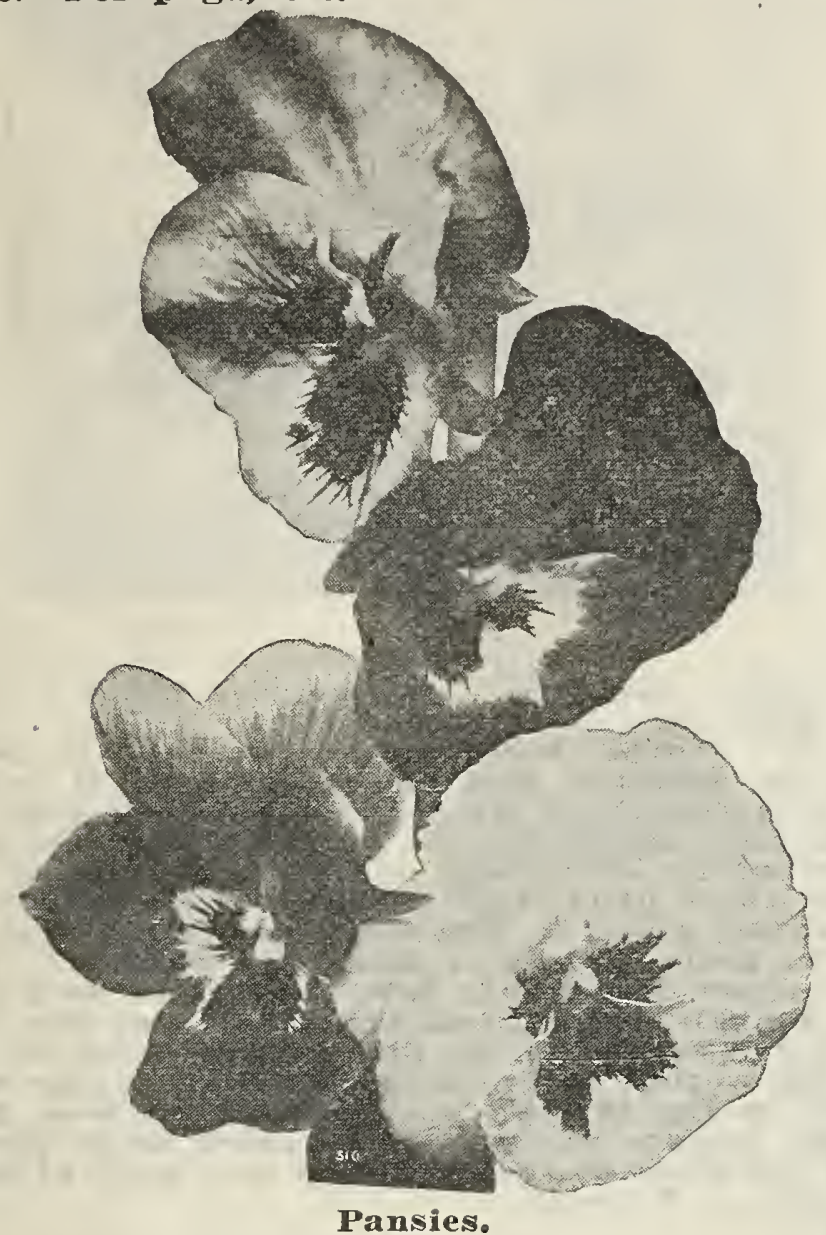

Poppies.-Probably the most conspicuous of all garden flowers. The beautiful array of colors makes it a splendid variety for boquets. The poppy will grow almost any place and thrive under almost any condition.

Double Mixed.-Blossoms exceedingly rare, double and somewhat resembling the Peony. Grows about 2 feet high. Per pkg., 5c.

Shirley Poppy. - A very hardy variety with single blossoms of every color. Per pkg., 5c.

Oriental Poppy.-An extra large flowering variety with blossoms often 6 inches across in all the bright shades of red. Very long stems. Perennial. Per pkg., 5c.

Phlox Drummondii-Very fine for a border as plants are only about 6 inches high. They produce an almost solid mass of bright colored flowers. If you plant the seeds early enough in the spring they will continue to bloom until kilied by the frost. Small and single flowers. Per pko., 5c.

Star Phlox.-The same as the Drummondii only that the flowers are star shaped. Per pkg., 5e.

Ricinis Castor Oil Bean.-A plant with very large palmate leaves handsomely lobed with very brilliant colored fruits. Very fine for lawns or bedding plant. Should be sown early in hotbeds and transplanted later. Per pkg., 5c.

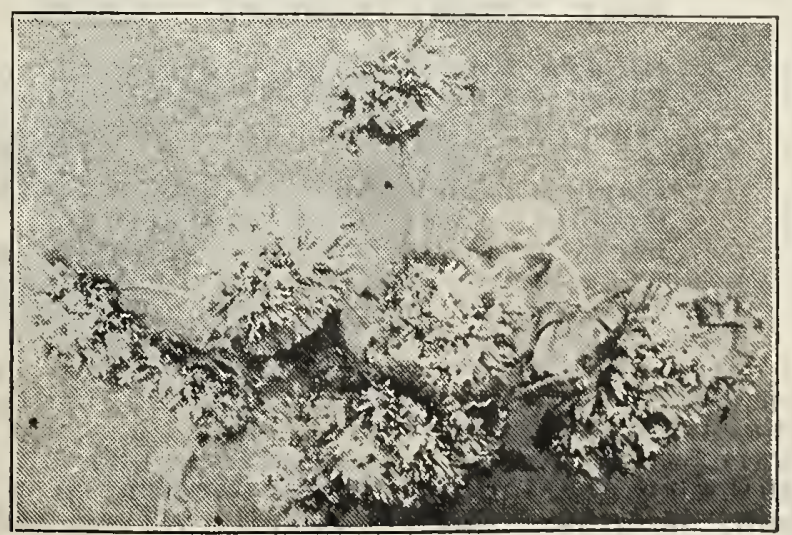

Shirley Poppies.

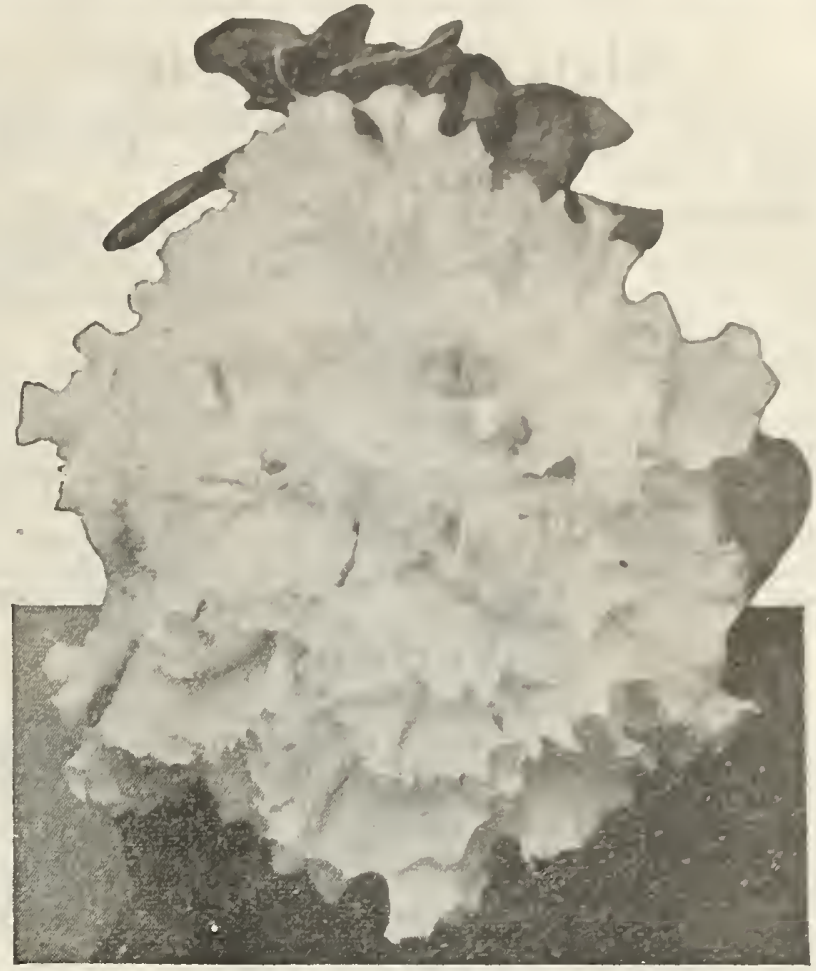

Petunia.

Petunias, Giants of California.-Plants require rich soil and sunny location blooming from July to October. Very fragrant blossoms of every conceivable color. No flower retains its freshness as long as the Petunia. Flowers are funnel shaped like the morning glory only their edges are beautifully ruffled and, frilled. Striped and blotched, single mixed, 10c; doubled mixed, 10 per pkg.

Primrose (Primula).- These are perhaps the most desirable of all house plants. They are in almost constant bloom all winter, and if the plants be transferred to the border they will bloom nearly all summer. Though perennial, few plants flower more continually and seed, should be sown every year. Give them a long time for growth before flowering, and do not force the young plants, but simply protect them from frost and danip and cutting winds. Height, 9 inches. Mixed, pkg., 10c.

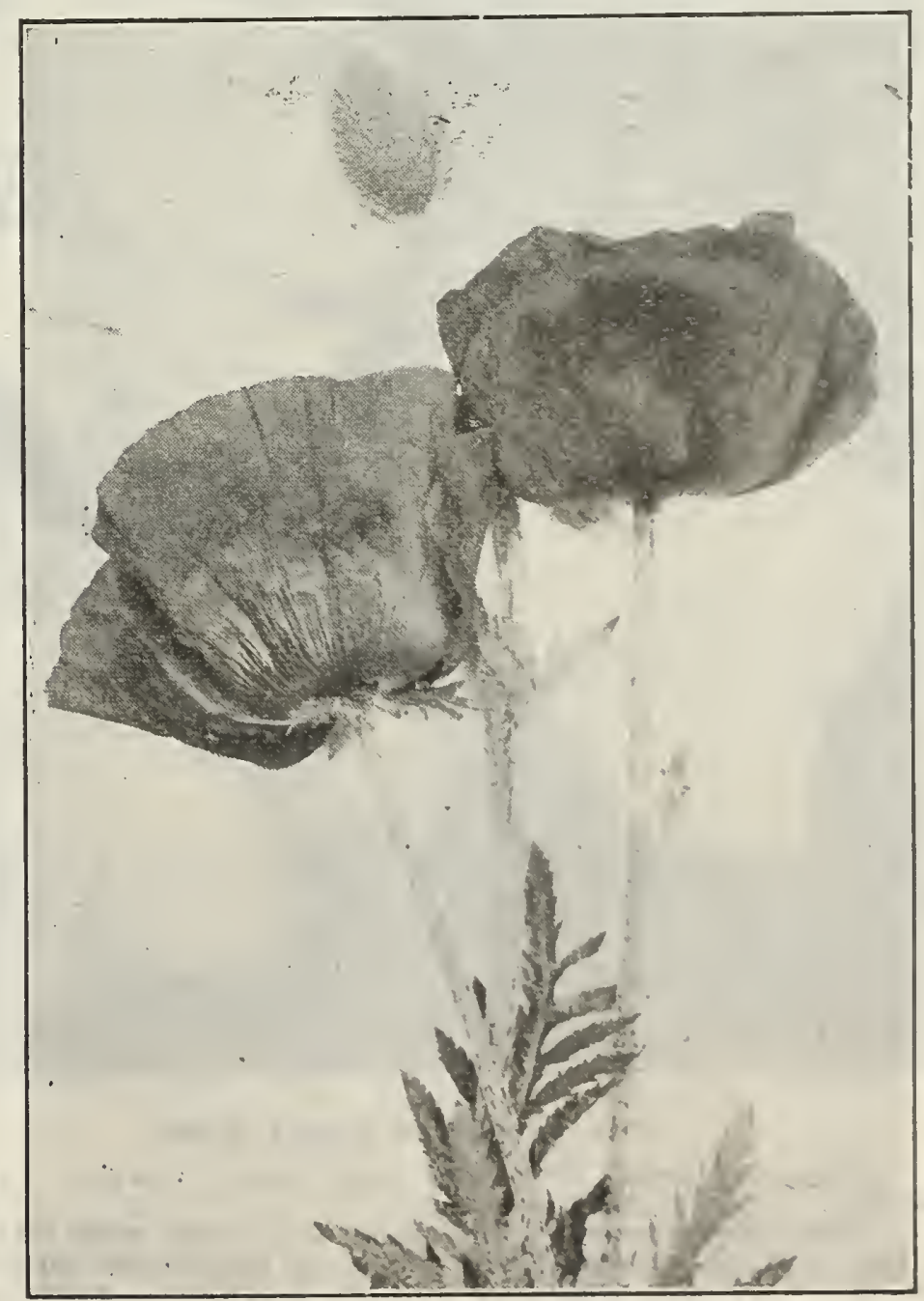

Oriental Popules. 


\section{Salvia or Scarlet Sage}

A very fine border plant with bright scarlet flowers produced on long spikes. A very fine autumn flower. Per pkg., 5c.

Smilax.-Grows about 10 feet high with small white flowers. Seed should be soaked 24 hours before sowing. Its beautiful dark green delicate foliage makes it very desirable for bouquets, baskets, vases, etc. Per pkg., 5c.

Salpiglossis. Painted Tongue.-This plant grows about 2 feet high and has very long stems, making it an ideal flower. Its flowers of many colors have the appearance of being sprinkled with gold dust. Extremely easily grown. Per pkg., 5c. Snapdragon or Antirrhinum.-Has curiously shaped flowers with distinctly marked throats borne on long spikes. All colors combined. Plants will thrive best in sandy soil. Perennial. Per pkg., 5c.

\section{Verbena}

A very fine flower for use as a cut flower. Sow seeds early indoors and transplant as soon as all danger of frost is over. Flowers are all colors borne in clusters. Per pkg., 10c.

Wild Cucumber vine.-A climber with very bright green leaves and pure white flowers followed by innumerable seed pods with barbed prickles. This vine remains fresh until killed by the frost and is not affected by insects of any kind. Per pkg., 5e.

Stocks.- Sow seeds early in hotbeds and transplant later. Very beautiful foliage producing blossoms on long spikes; one spike makes a bouquet by itself. Per pkg., 5e.

Sweet William.-A very widely known flower used extensively as a border plant. Very easily grown thriving in almost any soil. Per pkg., 10c.

Zinnia.-Seed can be sown outdoors very early in the spring and plants will produce an abundance of flowers in all colors and will bloom extremely late. Plants grow sc tall that it serves very well as a hedge plant. Per pkg, 5c.

Zebra.-A new variety of Zinnia with its petals striped and blotched with another color thus harmonizing beautifully. Per pkg, 5c. 5c.

Double Mixed.-All colors combined. Per plss.,

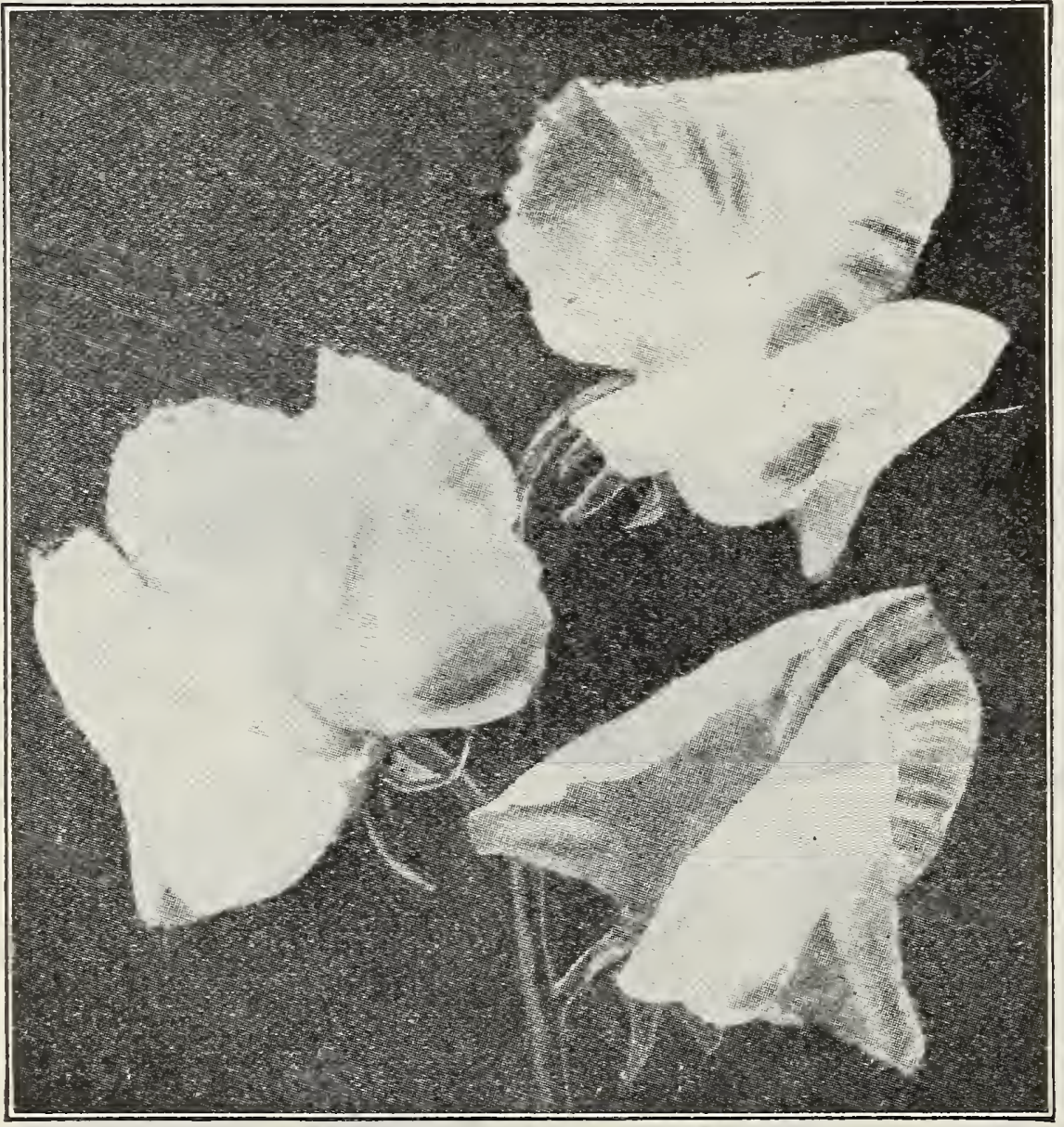

The President Sweet Peas.

Rozal Purple.-A very fine royal purple. 12 seeds for $25 \mathrm{c}$ or $75 \mathrm{c}$ per oz.

"The President." - The most brilliant, rich dazzling orange-scarlet Sweet Pea in existence, equal in color to the Oriental Poppy. a robust grower producing in abundance, flowers of largest size and broducing in abundance, flowers of largest size and 18 inches long. 50c oz.

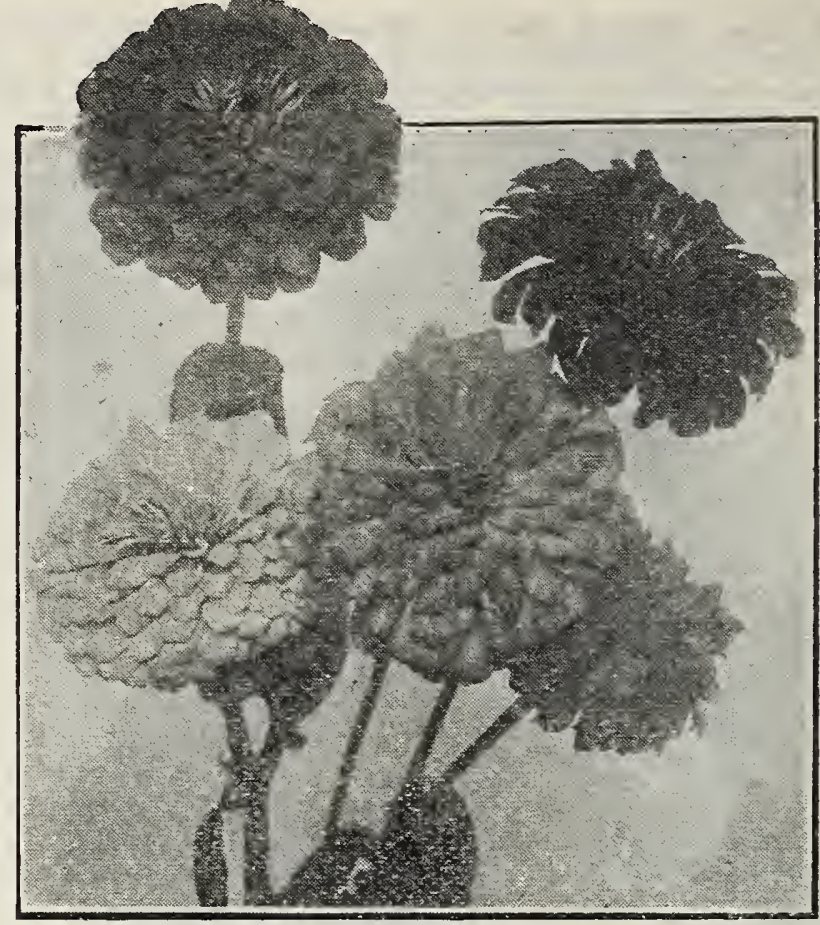

Zinnias.

White Gem.-Smaller but pure white in color. Per pkg., 5e.

Try Loebs IVild Flower Garden.-It is not just an ordinary wild flower mixture. It is made up of seeds of all the popular, hardy flowers, both wild and cultivated, such as everybody delights in growing in odd nooks and corners: and in open beds where little attention need be given to assure a profuse growth. The beanty of this mixture lies in the great variety of flowers it contains. It embraces not only all the best known and most popular annuals, but a great many new and rare sorts, gathered especially for this mixture from all parts of the world. In order to induce all of our custo. mers to try at least one package of these flower seeds, we are putting up an extra large package and sell them at the extremely low price of $5 \mathrm{c}$ per kg. or 7 for $25 \mathrm{c}$

\section{Nitragin for Sweet Peas.}

We specialize in Sweet Peas, carrying all varieties at all prices. A lower priced sweet pea does not mean an inferior grade, it merely means a smaller blossoming sweet pea. If the seed is sown early enough in the Spring it is not advisable to soak them as the ground contains plenty of moisture at that time. Dig a trench about 6 inches deep place the seeds in this trench but do not cover them more than $1 / 2$ inch, or 1 inch, at first. As the plants begin to appear cover them a little more until you have the six inch trench filled. They require very much watering and the flowers must be picked every day. As soon as the blossoms are allowed to go to seed the plants will cease blooming. Do not allow the white lice to strip your plants. When you see these little mites, procure a box of Bug Death and dust the plants thoroughly with same. Mixed colors. 5e pkg.; 10c oz

Bianche Burpee.-Pure white. 15c oz.

Kind Edward VII.-Bright red. 15e oz Blanche Ferry spencer.-Rose standard, white wings. 15e oz.

Hon. Mrs. E. Kenyon.-Large primrose. Clear buff-yellow. 15c oz.

Lady Grisel Hamilton.-Lavender. 15e oz.

Gladys Unwin.-Rose pink. 15e oz. Flora Norton.-Bright blue. 15e oz. Sincerity.-A beautiful deep glowing cerise

Early Canary Bird (Burpee's). -75c oz.

Othello.-Deep maroon. 15e oz.

Fiery Cross. - Fiery Cross has all the appearance of live fire the color being a scorching fire-red, or scarlet, without any shading and which scintillates and glitters in bright sunlight, thus adding a glowing, fire-like sheen which radiates over the flower. Unlike most of the orange-scarlet varieties, it does not scorch or burn even during extended periods of intense sunshine therefore it can be grown in all soils without fiocs are borne freely in threes and fours, wellplaced on long, stout stems. In sealed packages. 10 reeds, 25e. 
Thomas Stevenson.-Intense flaming orange; wings rosy carmine, shaded orange. $35 \mathrm{c}$. deepens at the outer edges and becomes still richer in cool weather. 25e oz.

\section{SUMMER FLOWERING BULBS}

Benutiful Gladioli-The Gladioli is the most attractive of all summer-flowering bulbs. Its mammoth flowers are produced on long spikes and comprise all the delicate shad,es of rose, pink, scarlet and white. Bulbs must be taken up before the ground freezes.

Fine Mixed Gladioli.-This mixture contains all varieties and colors mixed. For decorative purposes they are simply exquisite. By mail postpaid: Each, 10e; doz., 50e; 100, $\$ 4.00$.

Gladioli in Separate Shades.-We offer strictly selected first size bulbs only, sure to give satisfactory results the first season. Order early.

White and Light Shades.-Very desirable for cut flowers and exquisite indoor decorations. Doz. $65 \mathrm{c} ; 100, \$ 5.00$.

Pink and Rose.-Many shades from faint tints to deep rose and cherry, all very attractive colors Doz., 55e; 100 , \$5.00.

Searlet and Red.-Splendid, rich, bold colors. Doz., 50e; 100, \$3.50.

Orange and Yellow.-Unusual and charming shades in Gladioli. Fine for planting with the lighter varieties for a beautiful contrast. Doz. S0c: $100, \$ 6.00$.

Striped and Variegated.-All sorts of handsome color combinations, some with different colored throats, many with stripes and blotches. Doz., 65e; 100, \$5.00.

Pink and white shades.-Fine for cutting. Doz., 65e; 100, \$5.00.

Decorative Dahlias.-Very conspicuous autumn flowers and are admirably adapted for cut flowers. Start blooming in July and will continue to produce a mass of blossoms until killed by the frost. Flowers are produced on exceptionally long stems. Pure white, yellow, scarlet and red. Each, 35c, postpaid.

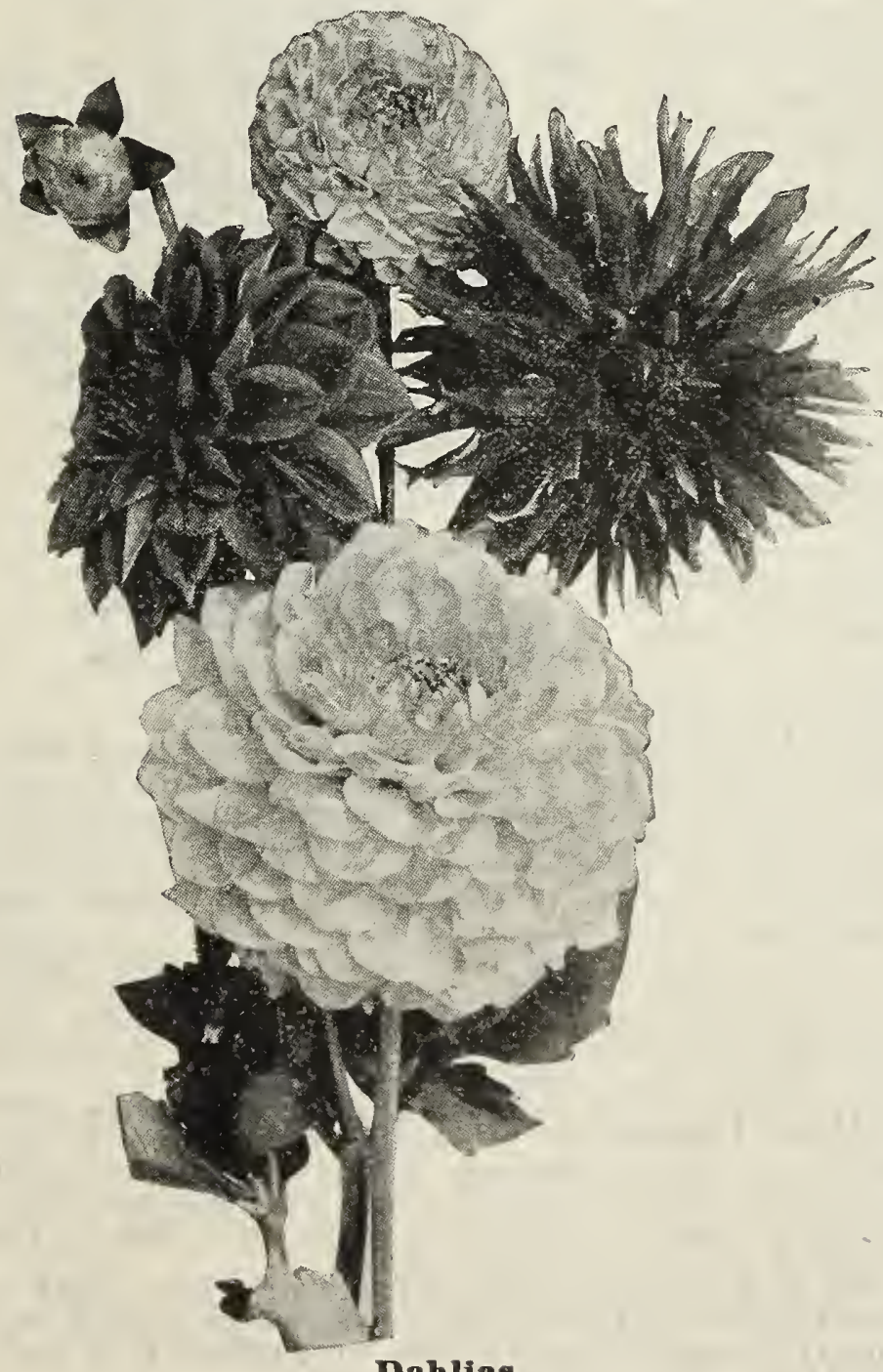

Dahlias.
Navy Blue.-Indlgo blue and violet. 15e oz Pince Edward of York.-Deep scarlet with Countess Spencer.-A sopt rose-pink, which crimson wings. 25e oz.

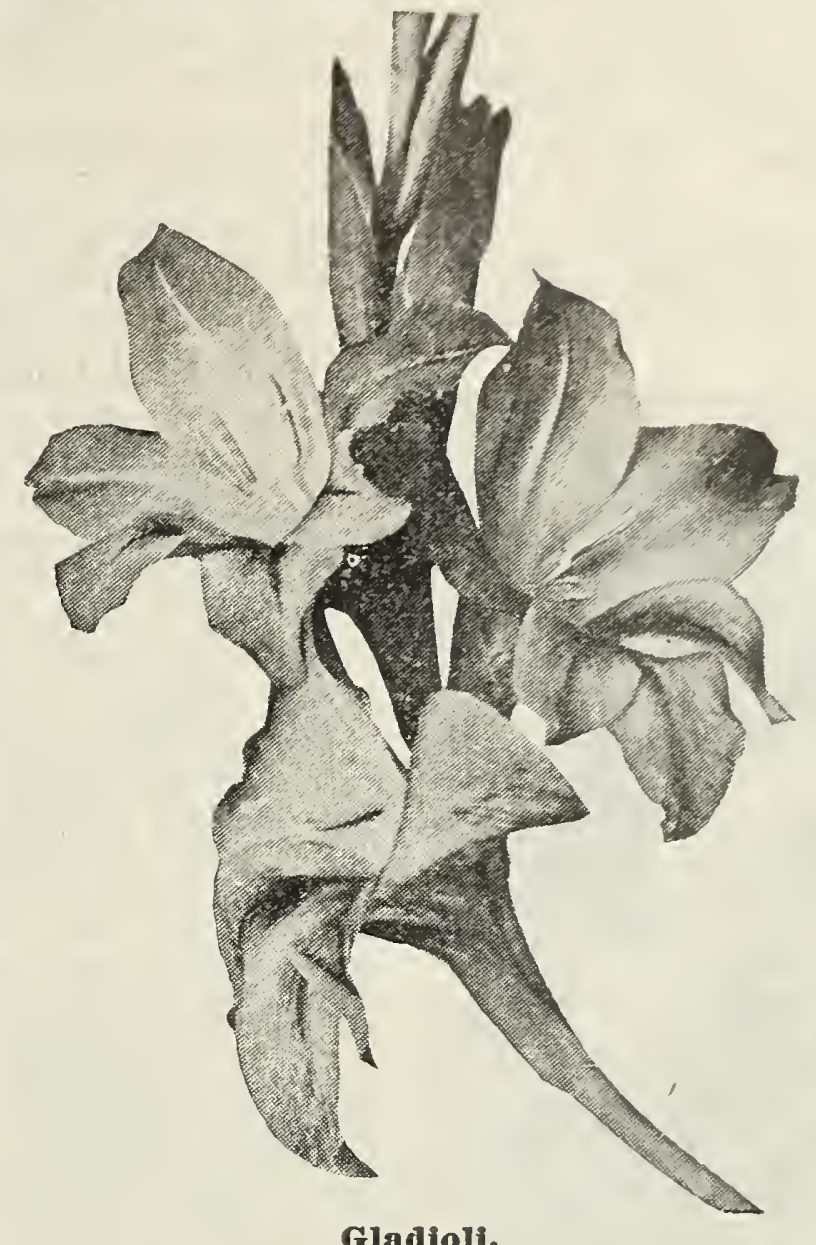

Mixed Cannas for Bedding.-A mixture of the finest dwarf, large-flowering kinds, which will go well together, and make a magnificent bed or border of bright colors. We can thoroughly recommend this mixture. Each, 25e; two for 40c.

oxalis.-Considered a very fine border plant as they do not grow very tall. Grown very easily and succeed in almost any soil. Mixed colors. Per doz., 15c; 25, 25e; 100, 90c, post paid.

Tuberoses.-Plants grow about it inches high and produce pure white, very sweetly scented flowers 5 to 7 inches in diameter. Each, 10e; $\mathbf{3}$ bulb. for 25e; per doz., 75e, postpaid.

\section{Bulbs for Autumn Planting}

Our fall bulbs do not arrive until about sept. 20 th. If your order for these bulbs is sent in the spring, it will be shipped promptly upon arrival of same. These varieties if planted early in the house same. These varieties if planted early in the house will bloom until very late long after

Crocus.-Small, single petal flowers, white with mixed shades of yellow, blue and purple, striped and variegated. Per doz., 40e; 100, \$3.00, postpaid.

Early Tulips.-The most widely known of all fall bulbs growing about 10 inches high and producing very brilliant cup shaped tlowers.

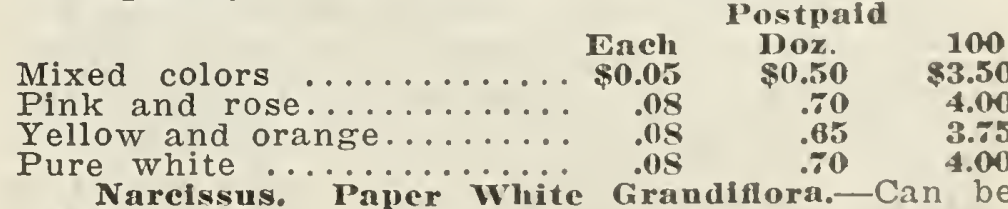

Nareissus. Paper White Grandiflora.-Can be made to bloom in December. There is no more satisfactory bulb for house cultivation. Snow white flowers. Each, 5c; doz., 50c.

Dafod , 5c; doz., 50c. Daffodil Has a rich golden yellow perianth and trumpet. This is the old favorite so highly prized in many old-fashioned gardens. Extra large in many old-fashioned gardens. Extra large splkes. Each, be: doz., 65e; 100 for $\$ 4.50$

Hyacinthus. - With vigorous plants producing their blossoms on long spikes. Flowers all shades, bell-shaped and pendulous. Mixed colors (Single and Double). Each, 15e; doz., \$1.25, postpaid. 


\section{LOEBS SUPERIOR RE-GLEANED GRASS AND CLOVER SEED}

Let us help you improve your crops, both in quality and quantity $\underset{\mathrm{m} \text { on }}{\mathrm{Wu}} \mathrm{y}$ and painstaking care into the farm seed line. We have to. We must supply better seeds than you can get elsewhere if we are to have your trade. The present-day farmer raises good grains and if we are to surpass them in quality, we have to keep wide awake and progressive. If our grass and are to excel in purity and vitality, it requires the closest scrutiny in buying and cleaning. We ask your trade solely upon our ability to please you.

Prices named in this department are always subject to important market changes. All quotations stantly varying in value. please write to any premium or discount. Clover and grass seeds are conders sent us will be given benefit of lowest prices on day order is received. Will take pleasure in mailing samples and quoting inside prices at any time on large orders.

Our Red Clover is grown in Northern Minnesota and is far superior to Clover grown in the South,

\section{Medium Red Clover}

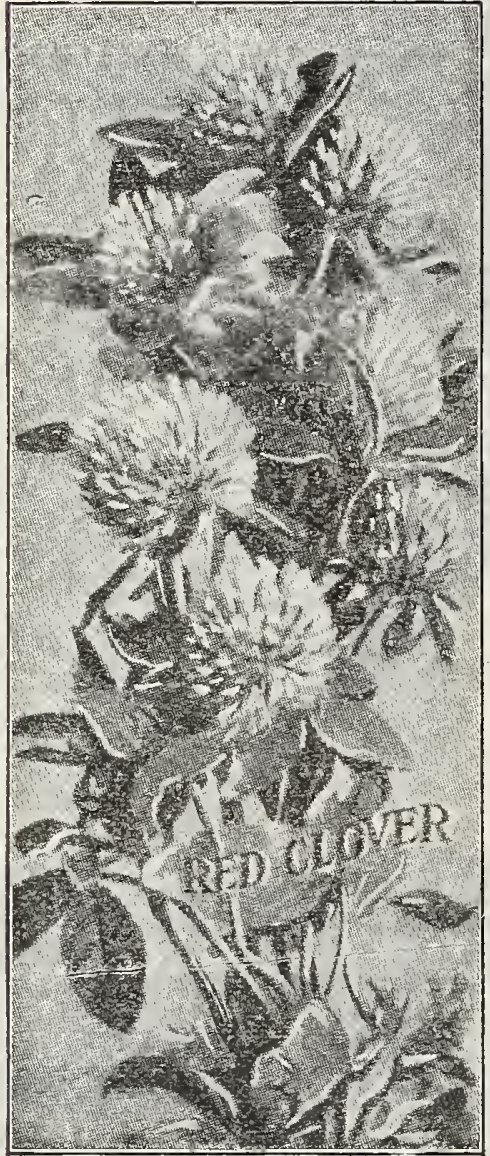

This is regarded as the most valuable of the Clover family. It is sometimes called June able all-around variety for farmers and stock. men. It makes $t w o$ crops each year. The first is susally cut when it is in blossom for hay; the last crop may be for hay, or plowed under to add fertility to the soil. It may be sown either in the Spring or Fall, and where no other grasses are used, at the rate of 10 to 12 pounds to the a c r e, according to quality of seed used, and condition of the soil. Clover adds greatly to the fertility of the land does not exhaust the soil, but enriches it. It pays always to buy the best qutlity of Clover seed which can be obtained. Even though the first cost is twice as much as cheaper seed, it will be found in the long run that in expensive on account of less hay or seed being produced from it. See Blue Price List.

White or Dutch Clover This hardy species perennial found generally throughout the United States. It is prostrate and creeping in habit, rarely growing more than a foot high. It is sown at the same time as Red Clover, but rarely alone. In lawn and pasture mixtures White "Clover is sown at the rate of 2 to 6 pounds per acre. White Clover has the relation to Kentucky Blue Grass that Red Clover has to Timothy. A small proportion of White Clover in permanent pasture often fills up many a bare spot and produces valuable grazing for all kinds of live stock. It withstands pasturage well and is not apt to cause bloat in cattle as is often the case with Red Clover. It disappears, however, in extremely hot and dry mid-summer, although it withstands drought better than Red Clover, but quickly revives on return of seasonable weather and rain in the early autumn months, It is also highly prized as a honey plant by beekeepers. See Blue Price List.

Alsike or Swedish Clover This is one of varieties known the $\mathrm{h}$ a $\mathrm{rdi}$ is $\mathrm{t}$ kill. It will do better on moist land than any other variety of Clover, and is suitable for either other variety of clover, and is suitable for either forms a thick undergrowth and greatly increases the yield. It is frequently sown both with Medium Red Clover and with Timothy, and the quality of hay thus produced is excellent. It is fine-stemmed and leafy and thus is quickly cured. It makes a very profitable seed crop in many sections of the Northwest. Sow 8 to 10 lbs. per acre. See Blue Price List.

Bags, extra, 65e each.
Mammoth Red Clov́er This is grown largely restore fertility to depleted soils. It makes good hay if cut soon enough although it has a coarser stem than the Medium Red Clover. Mammoth Red Clover supplies fine grazing for stock. It sometimes yields more seed than Medium Red Clover. Being a rank grower, it is very valuable for fertilizing purposes. The foliage, flower and stem are darker in color than the Medium Red Clover. It ripens later, and makes only one crop. Especially valuable on light, sandy lands. Eight pound,s of seed are sufficient to sow an acre on good soil. See Blue Price List. White Blossom Sweet Clover Melilotus Canadia. Experience has proved that, in many secions, it is a valuable addition to farm crops.

It is the most vigorous soil enricher of all the Clovers, and will usually make satisfactory growth on poor, worn-out soil which will not support ordinary farm crops.

The seed-

bed must be

and very firm.

The lack of a

firm seed-bed is

often the rea-

son why Sweet

Clover fails on

c u l t iva te d ally best to seed on ground such as Corn stubble that does not require ploughing, depending upon a disk or spike-toot h the seed.

It is seeded either in spring or fall, depending upon the climate. methods praceding are when so w n alone the best results are ob-

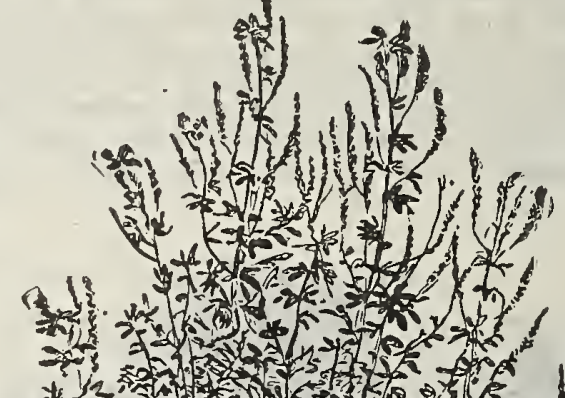

\section{(1)} nurse crop. Sow about 12 or 15 pounds to the acre. It is usually possible to get one cutting of Sweet Clover the first year and two good hay crops the second; or hay and pasture, or one hay crop and one seed crop. It is a splendid feed, about equal to Alfalfa.

Sweet Clover can usually be killed when mown in full bloom. It disappears completely under ordinary mowings or cultivation; for under such conditions it lasts only, two years and cannot reseed itself. See Blue Price List.
Yellow Blossom family as White Blossom Sweet Clover but is not so prolific in growth, will not produce so large a tonnage, does not grow quite so tall, but is from ten days to three weeks earlier.

The flowers are yellow instead of white. For bee pasture and fertilizing purposes, we believe it to bo equally valuable, but for hay or pasture it is not so desirable. See Blue Price List.

Use "Nitragin" for inoculating Clover. 


\section{A L F A L F A}

\section{THE GREAT LEGUME FORAGE PLANT}

Alfalfa is without doubt recognized as the greatest legume forage plant. Its value is recognized more and more by the best farmers throughout the entire United States. Its extension of culture has been without doubt retarded through misunderstanding of its requirements in the preparation of the seed bed, and in its cultural methods in securing and maintaining good stands. Within the past decade, however, many investigators have shown conclusively that equal care will make it respond as readily as any other forage crop. Undoubtedly, many farmers have believed it possible doubtedly, many farmers have believed it possible the seed bed, as well as giving proper attention to inoculating the seed and even in choosing the hardiest types.

Farmers, as a whole, have been too prone to select the variety of which the seed has cost the least. This has had a detrimental effect on extending the acreage. Many times, farmers have bought southern seed from common varieties, and expected these to withstand the extremes of drought and cold even in the north and west. Only failures have resulted from such trials.

While winter-killing is certainly to be guarded against in the north, it is as certainly not the bugaboo that many seem to believe. As seed from old fields of ten to twenty-five years standing in this climate is now easily procurable, there is no reason to believe that it will not produce as hardy seed as is required in this latitude. Such fields have necessarily withstood successfully the extremes of have endured almost annually, many of them, a have endured almost annually, many of them, a freezes and sometimes many degrees lower and often without any snow whatever Really, it seems true that with such seed used the matter of winterkilling should cause the prospective alfalfa grower very little concern.

Many farmers have, also, failed to secure alfalfa stands, because of seeding it on poorly prepared land. Many failures result from sowing al falfa on spring plowed soil. This land is entirely too loose. The seed bed when just turned over contains innumerable air spaces, and it is seldom that the farmer will pack it down thoroughly so that when the alfalfa is sown it will not sink deeper when the allali inch into the soil. Seldom does than one-half inch into the soil. Seldom does alfalfa grow well
half inch in depth.

Farmers should, therefore, realize the importance of selecting the proper land. A field that has grown a crop of corn, potatoes, or any other cultivated plant, is preferable to all others Generally. such land should be plowed in the fall, and given such land should be plowed in the fall, and given topdress and work begun early in the spring, so that the soil will warm up thoroughly. The cultivation of discing in the spring will loosen the surface and in the course of time the soil will pack thoroughly and alfalfa seeded on such land with a light nurse crop will invariably give a hundred per cent stand.

Many farmers also fail to inoculate and, in some instances, though they make the attempt, it is improperly done. No alfalfa will grow on land which does not contain the nitrogen gathering bacteria in sufficient numbers so that a majority of the plants will be inoculated within $a$ few weeks after they start growth. This is particularly true of soil that is light in texture. Sandy land must be thoroughly inoculated if alfalfa will make any growth oughly inocul

The general custom throughout most of the alfalfa territory is to seed during the spring. Several plans are suggested. Many farmers who have tried to grow alfalfa, know that ordinarily when sown alone, it will have to fight with weeds. It is, therefore, just as advisable to sow a nurse crop to cultivate the soil thoroughly until May or June, to cultivate the soil thoroughly until May or June, or even until the latter part of July, and just as cultivation has a tendency to kill out all weeds.

These methods, as described, will insure 100 per cent alfalfa stand. Failures may be attributed to some controllable cause. Alfalfa is not a fickle plant to get started. It is tender when small, and when not inoculated will hardly hold its own with a big crop of weeds or pigeon grass. When given a fair trial it will show its superiority over any other crop.

\section{Alfalfa Seed, Dakota No. 12}

The alfalfa seed which we are offering you as Dakota grown is known as Dakota No. 12. This seed comes from long established fields from the high and dry sections of South Dakota, consequently any plants that were not perfectly hardy have been killed out, leaving nothing but the hardiest to produce seed. Our South Dakota alfalfa wil produce the hardiest alfalfa plants and yield greatstate Experiment stations and other authorities state. Experiment stations and other authorities all agree as to the advantage of our hardy Dakota that will produce more foliage, either green or dry, than any known clover, sow Loebs South Dakota No. 12. We have a good supply of nice bright plump seed which we can guarantee almost 100 per cent pure. We are positive that you will be more than pleased with this variety. To insure positive and prompt delivery we must have your what you could order today."

See Blue Price List.

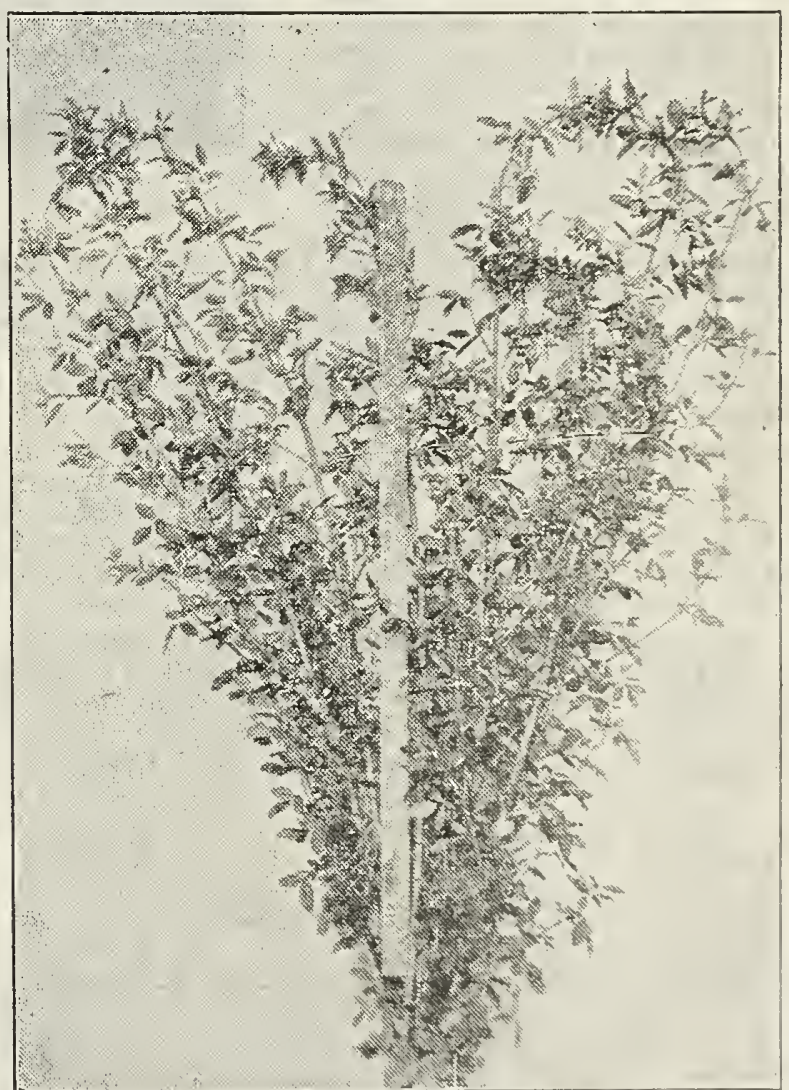

\section{Montana Grown Alfalfa}

Montana grown alfalfa seed has become quit popular during recent years in many sections of the country, owing to the fact that favorable state produce a good grade of seed that is extremely hardy.

Our Montana alfalfa was grown in the eastern part of Montana on high and dry land. The seed is exceptionally large and of high germination. Montana grown alfalfa is nearly as hardy as our Dakota No. 12, seldom ivinter kills, and is a great drought resister. The seed we offer is especially adapted for sowing in the Northwest where the temperature reaches both extremes, exceedingly hot and dry in summer, and down to 30 and 40 degrees below zero in the winter.

See Blue Price List. 


\section{Everlasting Grimm Alfalfa}

Grimm is the hardiest strain of alfalfa known in this country. It has the spreading crowns and many underground root stalks. These underground root stalks protect the buds from extreme cold in winter. The top crown buds may suffer, but these under-surface buds are rarely injured. It is for this reason principally that this is the type of plant adapted to the Northwest.

The non-hardy strains possess upright crowns and usually a straight tap root with few if any lateral roots and no underground root stalks. In severe winter

Within recent years Grimm alfalfa seed has gained in popularity, as it has demonstrated its superiority over common varieties. In various trials alfalfa of the Grimm variety has withstood against extremes of temperature and moisture con- ditions when common varietles have succumbed. many farmers will not hesitate to invest in it rather than in the cheaper varieties.

When purchasing Grimm alfalfa seed be sure that you are getting the genuine Grimm Grimm alfalfa is a high-priced seed and for that reason many concerns sell the hardiest varieties of Dakota grown alfalfa and designate it "Grimm." We buy no seed but such that we can trace back to the Grimm farm in Minnesota and every pound of seed we sell as Grimm we can positively gruarantee to be such. About eighteen years ago a neighbor of Mr. Grimm, of Minnesota, sent some of this seed to his son here near Aberdeen. He planted this seed and later distributed the seed throughout the state. We can furnish the names of any of these farmers to whom he sold this seed and will be glad to do so to anyone desiring same.

See Blue Price List.

\section{Kentucky Blue Grass}

Kentucky Blue Grass is the "King of Grasses." As a pasture grass it is without a rival. To the stock farmer it is his leading asset; once established, a Blue Grass pasture is a source of permanent income. Its only enemy is the burning rays of August sun, but with the returning cooler days and autumn rains it quickly restores its vigorous aftermath which remains abundant until checked by settled winter weather.

The main point is to sow early enough in the spring so that the grass will get a sufficient hold to resist the heat and drought of summer; or, if sown in the fall, the seeding should be in the latter part of August or early in September. If sown at that time, the to germinate quickly fall rains wh to cow rapidly; if sown much later it is liable to be killed by frost. If sown alone, 15 to $20 \mathrm{lbs}$. of good seed should be sown per acre. When used for lawns, sow at the rate of three bushels per acre.

Kentucky Blue Grass may be sown with Rye, Wheat or Barley: the grain should be sown first, the land harrowed and, if possible, rolled. After this the grass seed may be sown and covered very lightly; it will grow without covering, but light covering is advisable.

It is used mainly for lawn and pasture purposes. If intended for permanent pasture, it should not be grazed very closely for the first two years, or until it becomes well established.

Owing to its perennial habit and thick growth of sod, it is particularly suited for lawns or for turfing the slopes of terraces and embankments where the soil is good.

Sec Blue Price List.

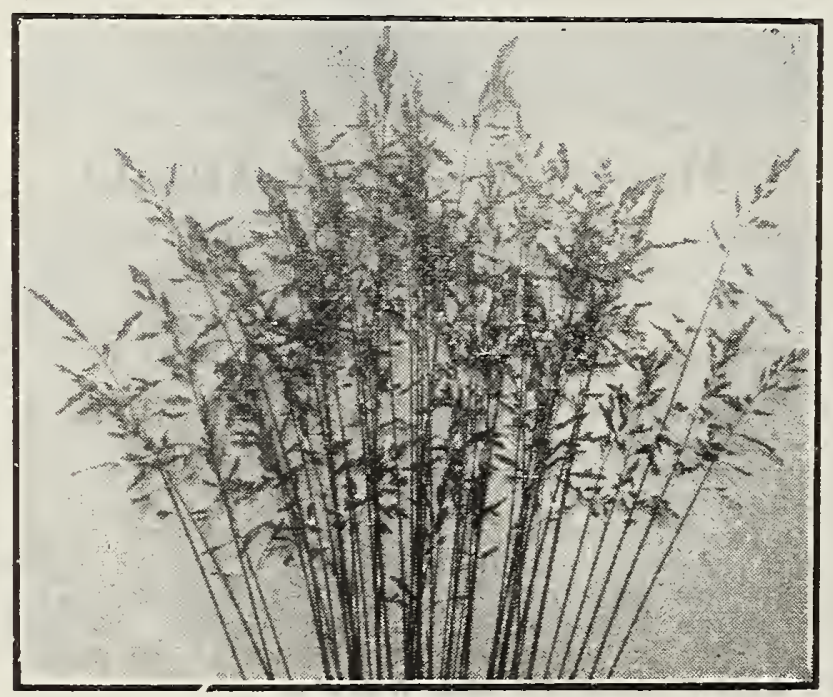

Blue Grass.

\section{Orchard Grass}

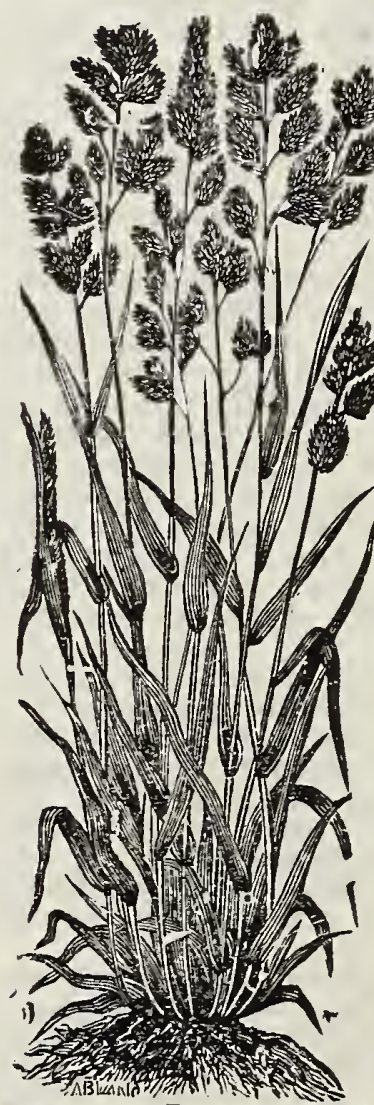

Orchard Grass is a standard grass, grown to some extent in every state in the Union. It yields about the same amount of hay as Timothy, and, if cut at the right period, is nearly equal in feeding value.

Orchard Grass grows upon every soil not saturated with water. It is easily established, however, on any fairly well-drained soil. The land should be plowed deep, and the soil well pulverized.

Twenty-five to thirty-five pounds of Orchard Grass per acre are required. A mixture of twelve pounds of Red Clover and twenty-five pounds of Orchard Grass is very desirable.

Orchard Grass is generally sown in the spring, but, under favorable conditions, will do well if seeded in the fall. It may be sown either with small grain or alone.

It is both a pasture and hay grass. After a crop of hay has been taken off in May or June, the aftermath will furnish a desirable pasture throughout the remainder of the summer and fall season. It stands grazing well, will resist drought better than almost any other grass, starts growth very early in the spring and is one of the latest grasses to be affected by frost in the fall. It will grow in the shade, which characteristic enables the farmer to utilize his wood lots as pasture. 


\section{Red Top}

Red Top is highly thought of, both as a permanent pasture and as a meadow grass for hay. It thrives under a wider range of soil and climate than any other cultivated grass. The sod of this grass is also useful in preventing soils from washing.

For sour or acid soils, swampy or meadow lands liable to overflow, or soils not quite rich enough for Timothy, or other Grasses or Clovers, Red Top is especially valuable. It will not do well in sandy or leachy soils, but it is said to be adapted to a wider range of soil and climatic conditions than any cultivated grass grown in America. sown alone, one birshel (14 pounds) of solid seed per acre is the usual rate of seeding. It may be sown alone either spring or fall, or with some small grain as a nurse crop. If covered being ing, it should be done very lightly,

preferale to is often sown with other Grasses and Clovers, especially Timothy and Clover. These additions increase both the quality and quantity of the hay. The dense sod of Red Top will continue its growth for a longer period during the year than almost any other grass.

See Blue Price List.

\section{Brome-Grass}

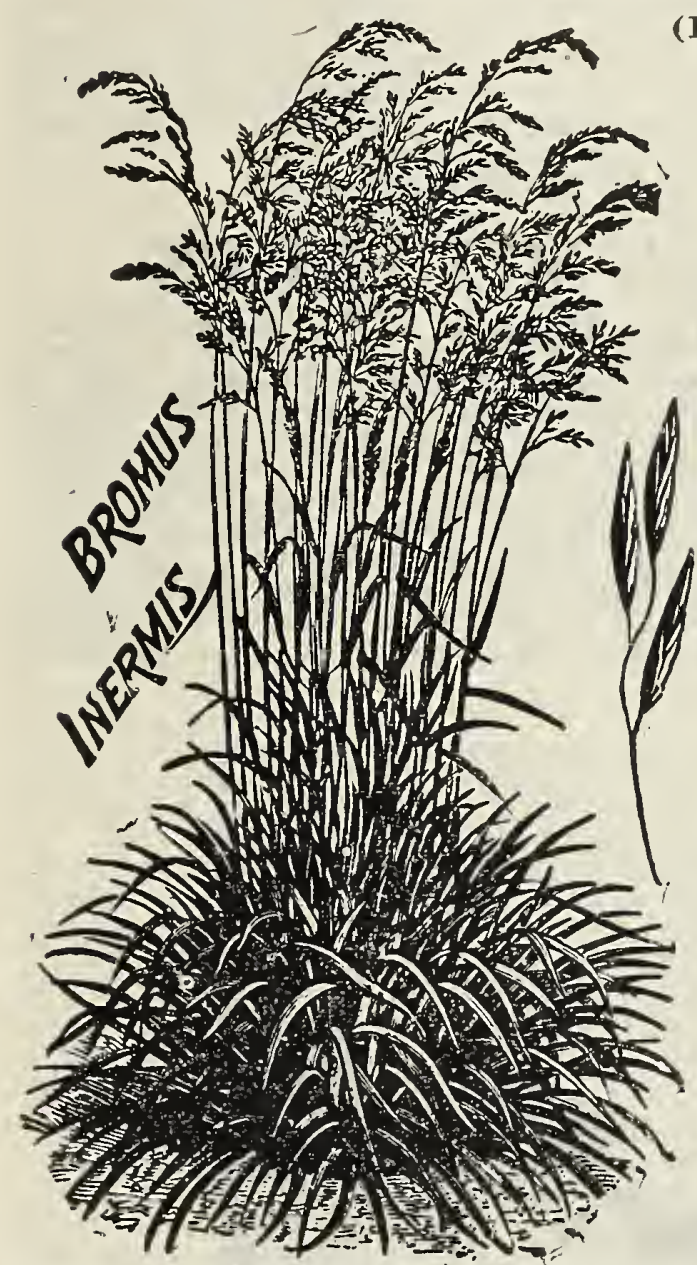

(Bromus inermis) The introduction of into the Grass into the arid regions of the W e s $t$ a $n$ d Northwest has given the people of $\mathrm{h}$ os ture and meadow grass of great promise.

A $s$ it is thoroughly permanent and g rows w it $h$ pidity, produc. ing, heavy crops and lux crops and lux uriant pastures, its value to the farmers in dry regions cannot be overestimated. All kinds of stock eat it with relish and chem i c a 1 analyses show that it is rich in fleshfor $\mathrm{m}$ in $\mathrm{g}$ ingred i ent smuch more so than Iimothy. h r $y$ and when once established, is not injured by severe spring and fall frosts. As it starts to grow very early in the spring before any of the grasses upon native prairies show any signs of life, and remains green and succulent far into November, it will supply the long-felt want of early spring and late fall pastures.

The yield of hay from Brome-Grass varies from one to four and a half tons per acre. The quality of the hay is excellent fully equaling that of Timothy in palatability and nutritive qualities. In order to obtain the best product, the hay should be cut at time of full bloom. One important feature which distinguishes Brome-Grass from othe hay grasses is that it does not deteriorate rapidly after the flowering period. After furnishing three or four crops of hay, the sod thickens up too much for a good growth of stems. This thickening occurs sooner if the grass is allowed to ripen seed than it does when it is cut for hay, or if it has been seeded heavily at first.

The land should be fall plowed, disked and harrowed thoroughly, then seeded in the spring. Sow broadcast at rate of 18 to 20 pounds per acre and harrow thoroughly.

See Blue Price List.

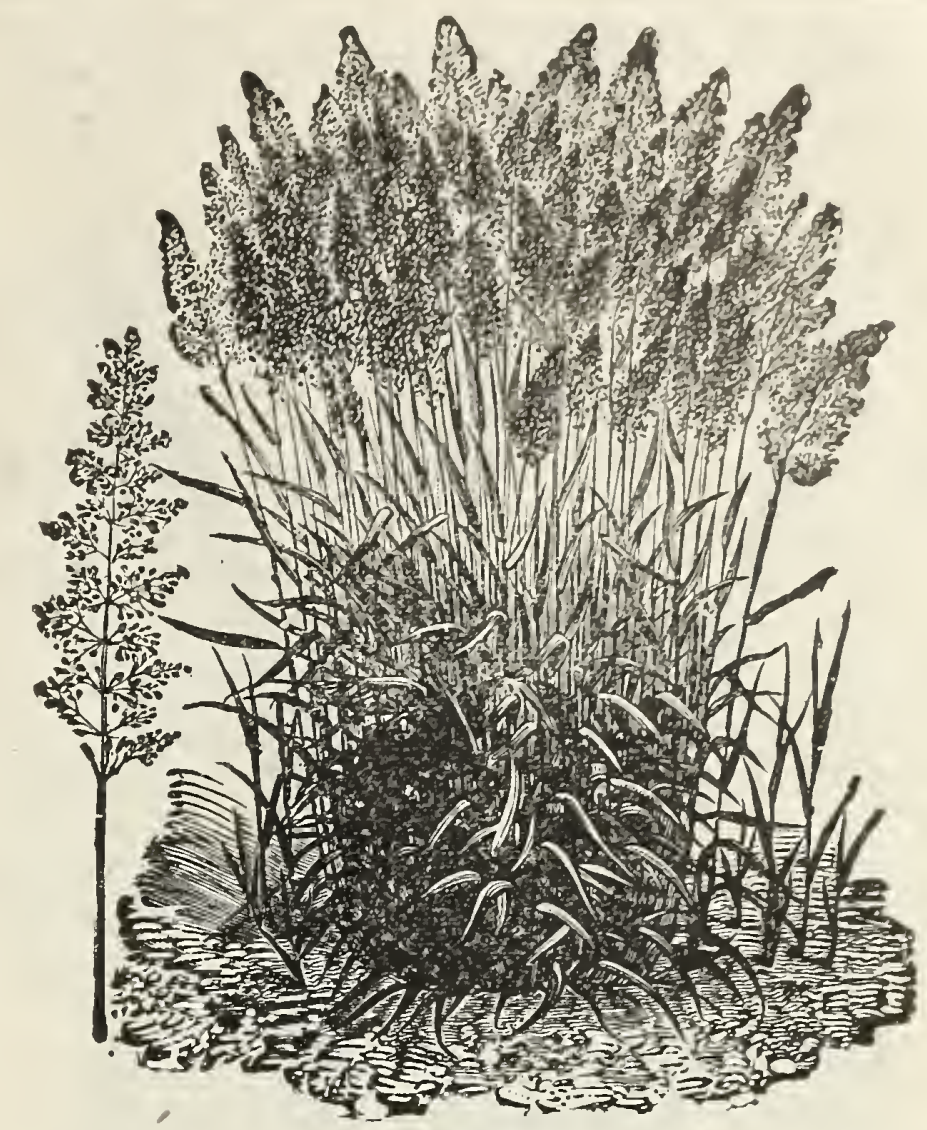

Red Top.

\section{Slender Wheat Grass}

Slender Wheat Grass, often called Western Rye Grass, is a native of this country and is cultivated in the Dakotas and the Canadian Northwest. The seed is sown in the spring as early as possible on a well-prepared and packed seed bed. It is usually sown at the rate of 20 pounds per acre with a nurse crop. Care must be exercised not to cover the seed too deeply. When sown with nurse crop, the grass does not yield hay the first season, but produces heavily the second year. Som growers suggest sowing Red Clover with this grass. Such a mixture helps to overcome the slippery nature of the grass and makes it more easily handled; it also gives a better aftermath for pasture. It is not advisable to practice autumn seeding on account of the severe winters in sections where it is grown.

Slender Wheat Grass is better adapted to use as hay than Bromus inermis, but does not afford as good a pasture since it does not propagate by root stocks and consequently does not withstand stamping and grazing. This grass is also becoming popular in crop rotation, especially in northcanada this purpose many farmer value it more than Bromus, as it can be plowed up without difficulty and the land seeded to some other crop.

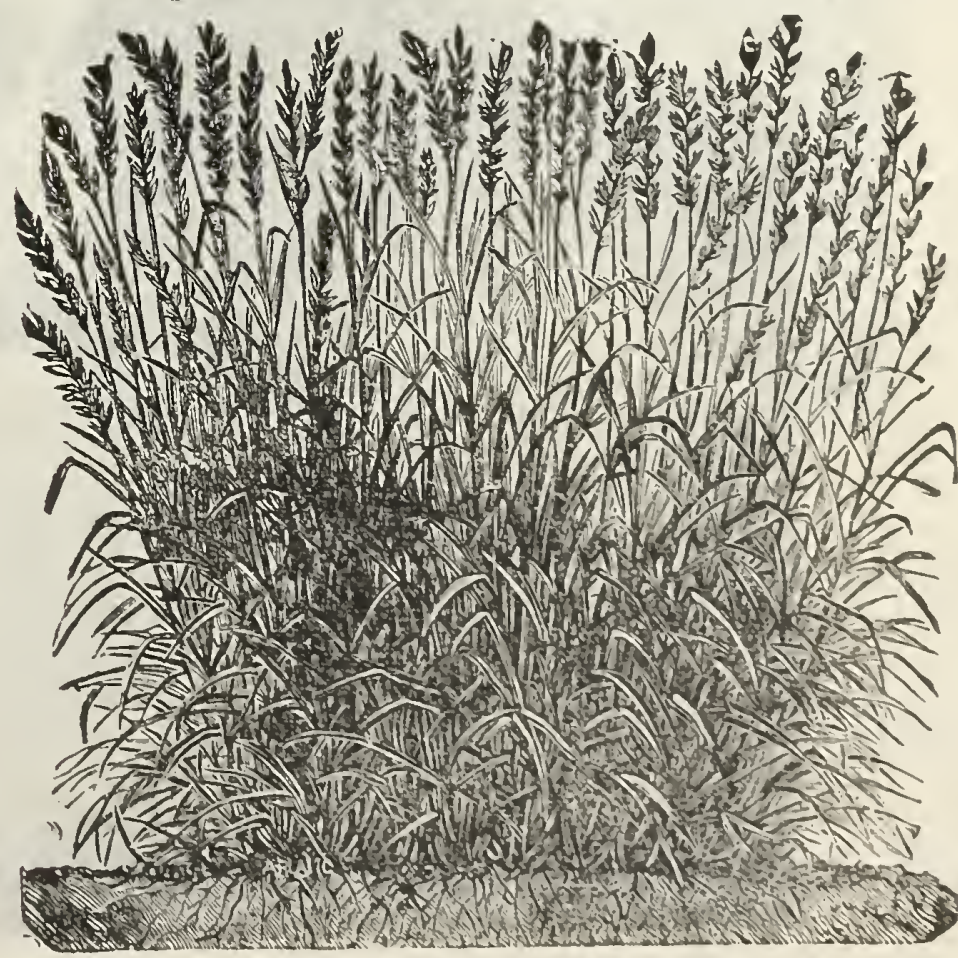

Whent Grass. 


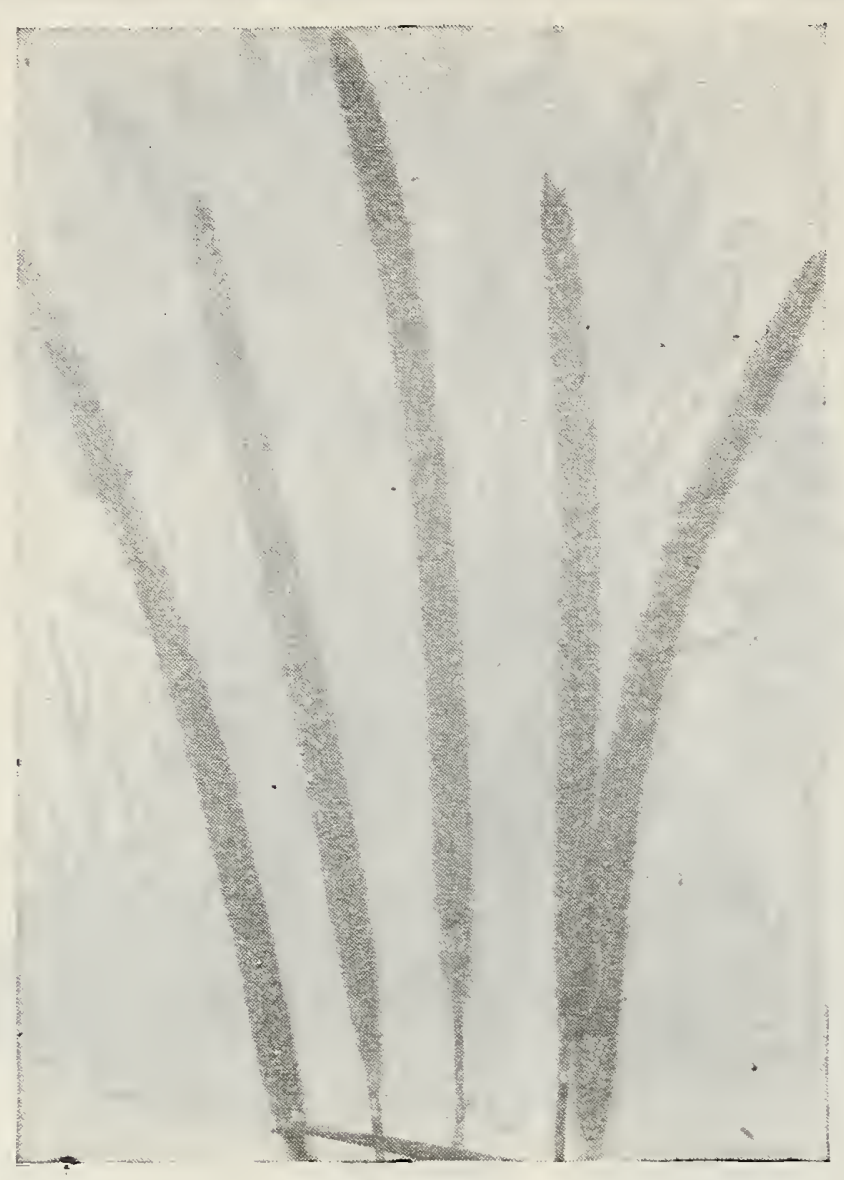

Timothy.

\section{Timothy}

Timothy is the standard hay of commerce. The cheapness of the seed, the ease of culture, and excellent quality of the hay make it a favorite.

It is adapted to all soils, but succeeds best on moist loams and clays. The life of a Timothy meadow varies according to soil and climate. It produces more profitable yields the first and second years.

Timothy is grown in a four or five-year rotation; 15 pounds of Timothy are considered a full seeding when used alone; when seeded with Clover, Wheat, Oats or Barley, 8 to 12 pounds of Timothy with 4 to 5 pounds of Red Clover is a desirable mixture.
It is preferable to cut Timothy after the seed is formed and in full milk on account of the roots being better able to withstand drought. It should be cut 4 inches from the ground, as most Timothy is killed by mowing close and early, before it has come to maturity.

See Blue Price List.

\section{Meadow Fescue}

Meadow Fescue, or English Blue Grass, as it is sometimes called, is a valuable hay and pasture grass. In nearly áll the northern states and in grass. In nearly all the northern states and in into special favor. It may often be used to advaninto special favor. It may often be used to advantage in permanent pasture and meadow mixtures, lands, as it grows very rapidly and tends to keep down the coarser grasses which naturally grow in such places. It will thrive in wet pIaces when trampled Grass or Clover would fail. It is particularly Grass or clover would fail. It is

adapted to clay and other heavy soils.

Seeding.-Meadow Fescue is usually sown in the fall, from about August 15th to September 15 th, without a nurse crop. It may also be seeded in the spring. The seed bed is generally prepared by disking a cornfield or plowing under grain stubble. A finely pulverized, firm seed bed is necessary for the proper germination of this, as well as other kinds of grass. The seed may be sown broadcast and covered with a harrow as other grass and Clover seeds usually are. Fifteen to 20 pounds of seed per acre are recommended.

Meadow Fescue produces a good quality of hay which is readily eaten by all kinds of stock. Generally speaking, it does not yield so much hay as Timothy, but when established the meadow will live longer. We recommend this for a hay crop where Timothy does not do well.

BAGS EXTRA, 65c.

\section{See Blue Price List.}

\section{GRASS MIXTURES}

Mixture for Hog Pasture This superior mixsidered very heavy seeding and expensive, but if you desire a permanent hog pasture, you cannot afford to be conservative on seed or limit the varieties. This mixture contains the following varieties of grass, also the actual percentage of each that the mixture contains: White Blossom Sweet Cloevr, $10 \%$; Alfalfa, 10\%; Red Clover, $4 \%$; AlSike Clover, $4 \%$; Timothy, $5 \%$; Kentucky Blue Sike Clover, 4\%; Timothy, 5\%; Kentucky Blue $15 \%$; Bromis Inermis, $8 \%$; Red Top, $8 \%$. Twenty pounds per acre.

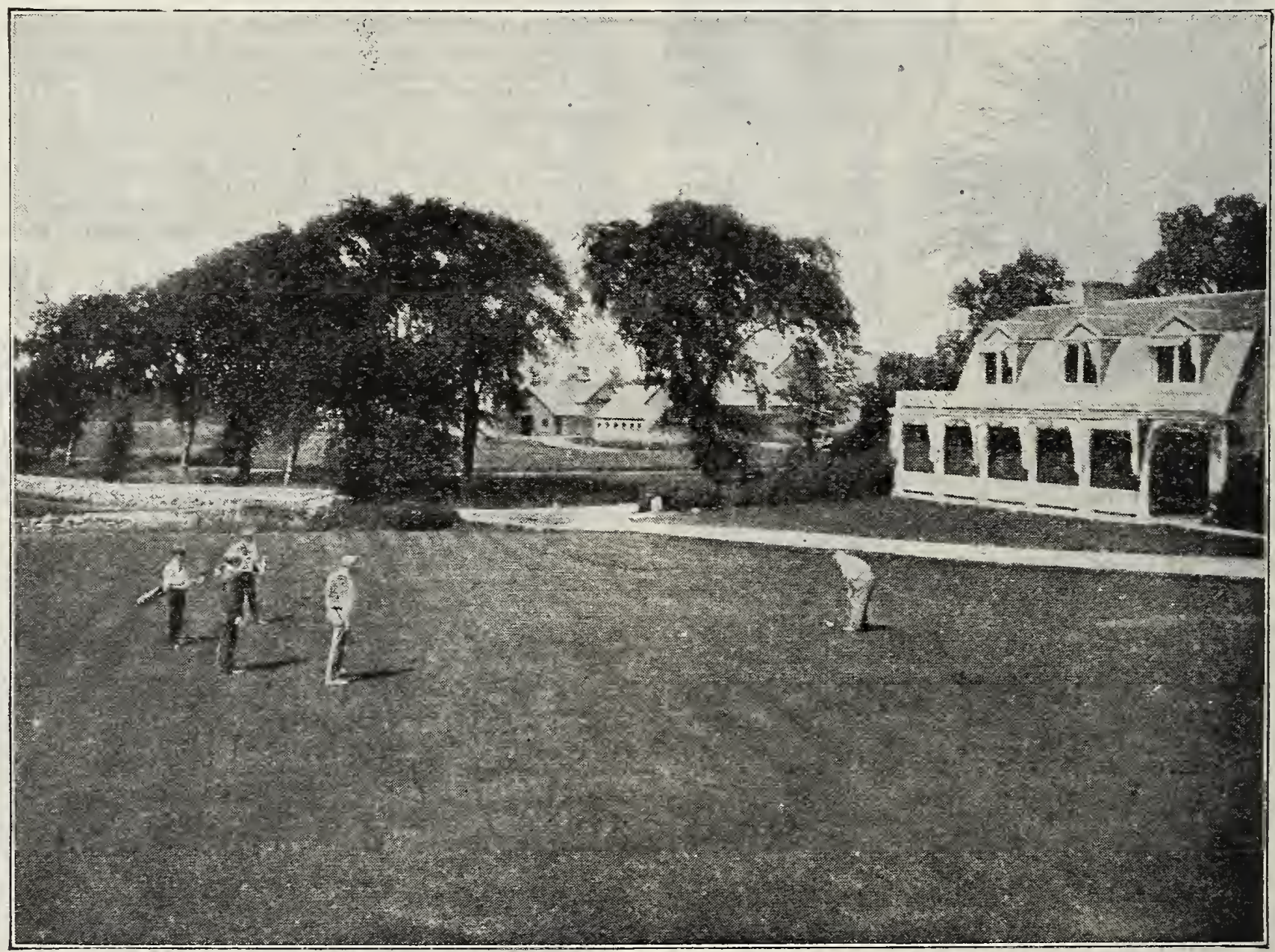

Lawn from Locbs Lawn Grass Seed. 
Mixture for High Land This mixture is ture and hay Contains the following varieties grass and their respective percentage: Alfalfa, $15 \%$; Red Clover, $10 \%$; Timothy, $10 \%$; Bromis Inermis, $15 \%$; Alsike Clover, $10 \%$; Slender Wheat Grass, 15\%; White Dutch Clover, $8 \%$. Fifteen pounds per acre.

See Blue Price List.

Mixture for Low, Damp Soil This mixture for hay, but is better for pasture. Contains the following varieties of grass with their respective percentage: Alsike Clover, 10\%; Meadow Fescue, $20 \%$; Red Top 15\%; Bromus Inermis, $15 \%$; Orchard Grass $30 \%$; Slender Wheat Grass, 20\%. Twenty pounds per acre.

\section{See Blue Price List.}

\section{LOEBS LAWN GRASS SEED}

In procuring seed for establishing a lawn, too great care cannot be exercised. Pure seed, of high germination, is of great importance in securing a good stand of grass. Pure seed is the keynote: to clean lawn, provided the work of preparing the land has been efficiently done. Thorough preparation involves not merely the mechanical treatment of the soil to reduce it to a proper seed bed, but the use of weed-free manure and the adoption of a course of treatment previous to preparing for the lawn which shall serve to eradicate weeds. Such preparation, coupled with pure seed, should give a satisfactory stand of grass which shall need only the usual care necessary to maintain a lawn after it is once established. Too much cannot be said in favor of securing pure seed, and, if possible, specially selected seed. This is, of course, of considerable importance with light seeds like blue grass, red top, and seeds of the bent grasses. In pounds to the bushel, while the ordinary grade of blue grass, although it may be called pure, averages about 12 pounds to the bushel.

Select or recleaned blue grass is, therefore, the most economical to buy, although the original cost is considerably more than that of the common article. The stand of grass resulting from the use of recleaned selected seed is much more uniform than when seed containing a great number of hulls and light seeds is employed.

In order that seeds of suitable character may be secured, it is desirable in the first place to determine the varieties which succeed best in the 10cality.

The largest users of lawn grass seed use Kentucky blue grass and red top either equal parts, by weight, or more often two parts blue grass and one part red top, sowing in either case 70 pounds to the acre, and in most cases sowing also 6 quarts of white clover to the acre.

Our lawn mixtures are composed of approximately one-third Kentucky blue grass, almost as much red top, with Rhode Island bent, creeping bent, sheep fescue, red fescue, and a little sweet bent, sheep fescue, red thescue, and a little sweet vernal grass to give the lawn a pleasant odor when cut. These mixtures are admirably adapted wet, of the average lawn.

Loebs "Hub City" Lawn Grass Seed Loebs "Hub City" Lawn Grass Seed is the cleanest, the heaviest, the cheapest, the best, because it is made up of Extra Recleaned Seeds of the close-growing varieties best adapted for the purpose. It is composed of the finest varieties of grasses, each of which has its season of beauty, and the result of its blending is the production of a sod that is always evergreen and velvety. Many of the "finest lawns of our city are seeded with Loebs "Hub City" Lawn Grass, the preparation of which is a specialty with us. Being free from chaff, it requires less seed of Loebs "Hub City" than any other brand. Hence it is economical in the end. One pound will sow 450 square feet. the end. One pound will sow 450 square feet. Not prepaid: Lb., $45 \mathrm{c} ; 5$ ibs., $\$ 2.25 ; 10$ lbs., $\$ 4.00$.

\section{Loebs Quick Growth Lawn Seed}

We frequently have inquirles for a lawn mixture which will give quick results, and our "QUICK GROWTH" has been prepared with this end in view. It is especially useful where for some reason or other the seed cannot be sown in early spring. Where sowing must be delayed untll May, the Quick Growth mixture will cover the ground like magic, and later on produce a permanent and beautiful sorl. Prices, ly mall, postpatd: I,ls.. sole? 10 ibs.s \$3..00; $2.5,1 \mathrm{bs.}, \$ 8.00$.

Loebs Evergreen Lawn Grass Seed FOIR SHADY P'LACES

Can nearly all by the fact that ordin

consequently

which naturally

ing in such plac

at the rate 0

Prices, by mail, postpaid, Lh. 50c: 1 lhs $\$ 1.40$ Not prepaid: Lb., $450 ; 5$ ilos., $\$ 2.00 ; 10$ lbs., $\$ 3.50$.

Blue Grass and White Dutch Clover Lawn Mixture

We personally consider this our very best lawn seed. It is the finest and purest of all grass seed and is indeed reliable. The demand for this one variety alone is as great as that of all the other varieties combined. Contains $66 \quad 2-3 \%$ Kentucky Blue Grass and $331-3 \%$ White Dutch Clover. Per $1 \mathrm{lb}, 55 \mathrm{c}$, postpaid; $45 \mathrm{c}$ per $1 \mathrm{~b}$. by freight or express. Kentucky Blue Grass (alone), 45 c per 1 b., postpaid; 35e per lb., freight or express. White Dutch Clofreight or express.

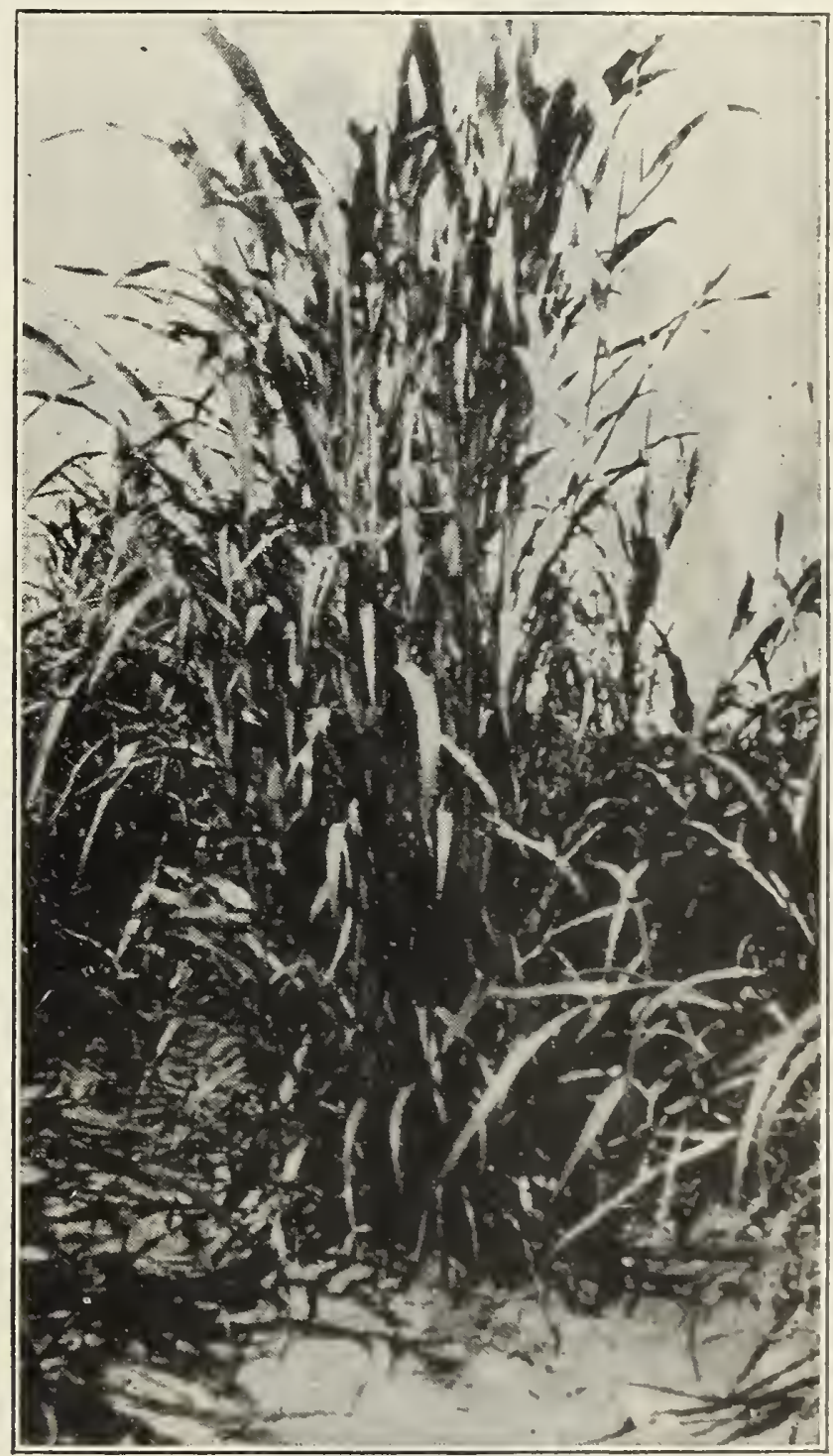

Sudan Grass.

Sudan Grass

This grass was introduced by the Department of Agriculture and it has been tested at several experiment stations.

Sudan Grass belongs to the Sorghum famlly. It is an annual, lacking underground root stalks. Two cuttings can be obtained under favorable conditions, and growers near Minneapolis report two big crops last season. The yields vary from 1 to 8 tons of cured hay per acre.

Sudan Grass when seeded broadcast or in drills averages about 3 to 5 feet in helght and has stems 
a little smaller than a lead pencil, being about three-sixteenths of an inch in diameter. If grown in rows and cultivated it reaches a height of 5 to 9 feet, and, the stems are larger than usual, being about one-fourth of an inch in diameter. The panicle is loose and open.

Sow Sudan Grass after the soil has become warm, about corn-planting time. It may be drilled from one-half to one inch deep. For seed production, sow $6 \mathrm{lbs}$. per acre in rows and cultivate. When broadcast, sow 16 to $24 \mathrm{lbs}$. per acre. It may bo cut with a mower or binder.

\section{Early Amber Sugar Cane or Sorghum}

Amber Cane is one of the oldest and earliest maturing varieties of Sorghum now in use. It requires approximately 70 to 100 days to mature, depending on soil and climatic conditions. Because of its early maturity it has become very popular. Since the growth of the rlants is very slow during the first few weeks, it is essential to have the soil free of weeds and of good tilth, otherwise the plants may be overwhelmed with weeds. May be sown broadcast at the rate of 35 to 40 pounds per acre, thus producing a fine quality of hay, or planted in rows to its great adaptability as a food for live stock, it can be profitably grown everywhere, from the extreme north to south. It grows right along

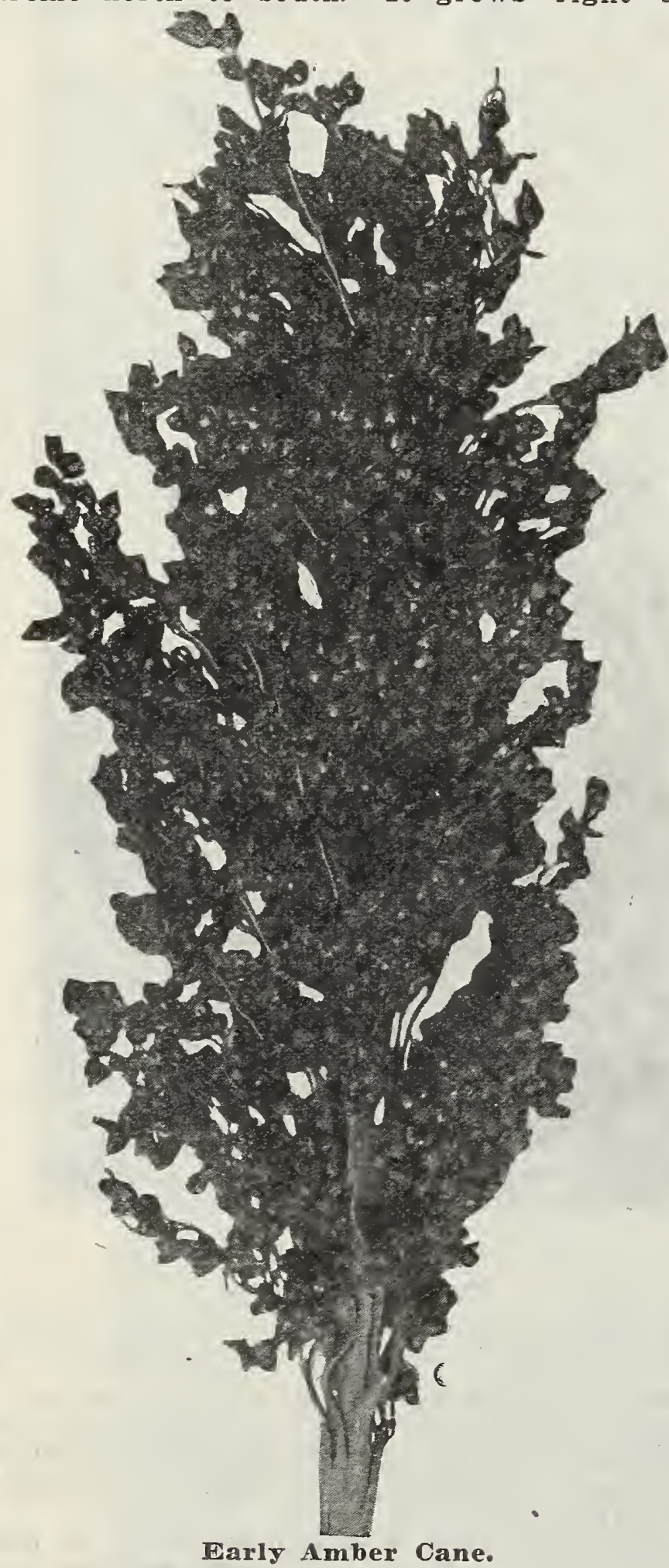

through the severest and most prolonged drouths, after the plants have secured a good start. It springs up quickly after being fed or cut. See Blue Price List.

Kaffir Corn Grows 4 to 5 feet high. The stalks merous wide leaves and does not harden like other varieties of sorghum. It makes excellent fodder for all kinds of stock and is highly relished by cattle. For fodder sow 25 to $50 \mathrm{lbs}$. per acre, either cattle. For fodder sow

\section{See Blue Price List.}

Feterita We know of no other variety of seed Feterita that has ever sprung into such popular favor. Feterita has taken the country by storm. The two best features about Feterita are its wonderful ability to resist drouth and its earliness. We advise you to plant a good acreage of Feterita and especially if you live in a region subject to extremely dry weather. We also advise you to get your seed early as there is going to be an immense demand for this wonderful grain.

Milo Maize Corn It produces large quantigrows well where Amber Cane green fodder. It is an excellent fattener, and relished by all cattle, hogs, etc. Stalks 5 to 6 feet tall. See Blue Price List.

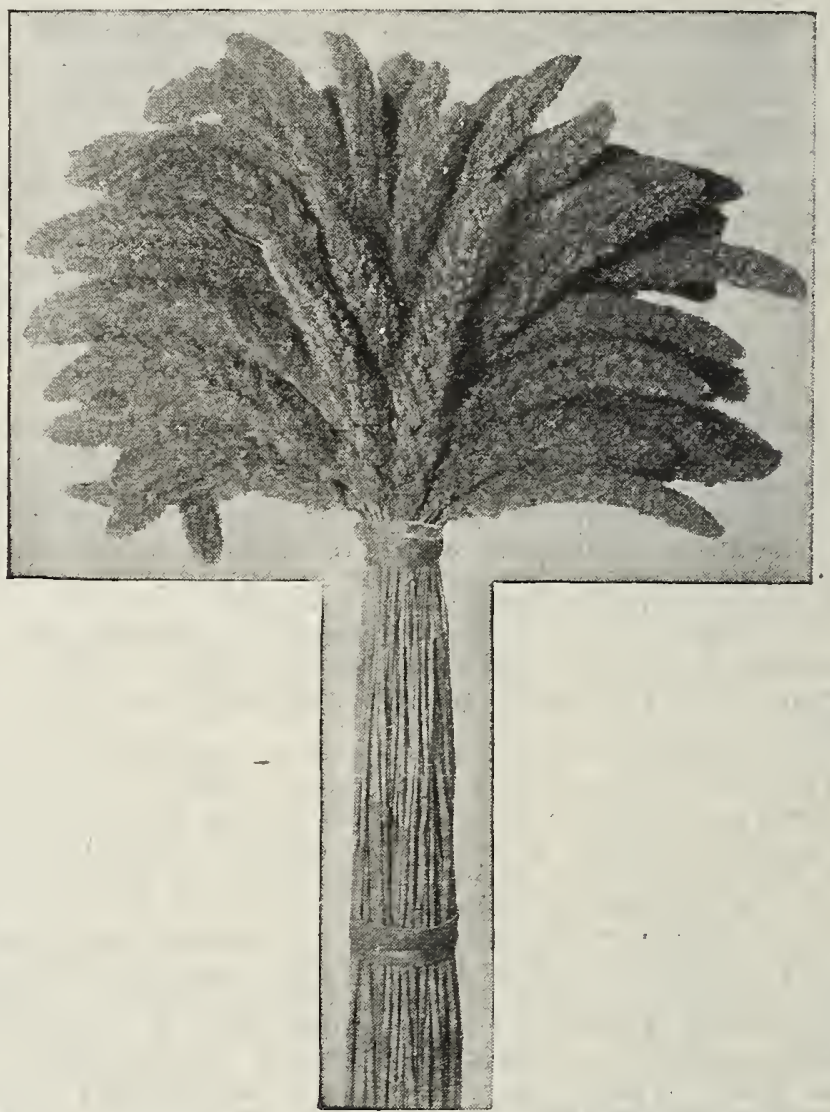

Golden Millet (True Southern Grown Seed). In altogether taller than does that from Northern seed, and that means more hay. It is finer than that from Northern seed, and that means better hay. In fact, it is our judgment, based on an experience of many years, that a farmer had better, from the standpoint of profit alone sow Southern grown Millet than to sow the best Northern Millet as a gift. Millet seed produced in the North, even from Southern seed, becomes what we call Common Millet. Not only does the plant dwarf, but the seed itself shows a change, and is readily distinguished by those experienced in hanreadily

We wish to say that any Millet seed offered and shipped by us as Golden Millet is true Southern grown seed, and that only.

Golden Millet is very sweet, palatable, and when fed to dairy cows produces a large amount of milk. On good rich soil it grows four to five feet high It is very tender if cut at the right stage, which is when it is in full bloom About three-fourths of a bushel of seed is sown to the acre; $501 \mathrm{bs}$. per bu. A good yield is from three to five tons of hay to the acre.

See Blue Price List.

Bags, extra, 65c each. 
Golden Millet (northern grown) As stated Golden Millet does not yield so much hay nor so good hay as the Golden (Southern Seed). It is usually much cheaper than true Golden. Grows usually from $2 \frac{1}{2}$ to 4 feet high and makes excellent hay. Sow about three-fourths of a bushel to the hay. Sow about three-fourths of a bushel to the fine lot of Golden Millet which is as nearly perfect in quality as Golden Millet can be.

\section{See Blue Price List.}

Common Millet Common Millet is the earliest Com of the commonly grown varieties. It is also very drouth resistant and will give fair returns on the poorer class of soils. This millet may be grown to advantage in some of the northern sections of the millet belt. The hay produced from this variety is not coarse as some of on this account. Bu., $\$ \mathbf{3 . 0 0}$.

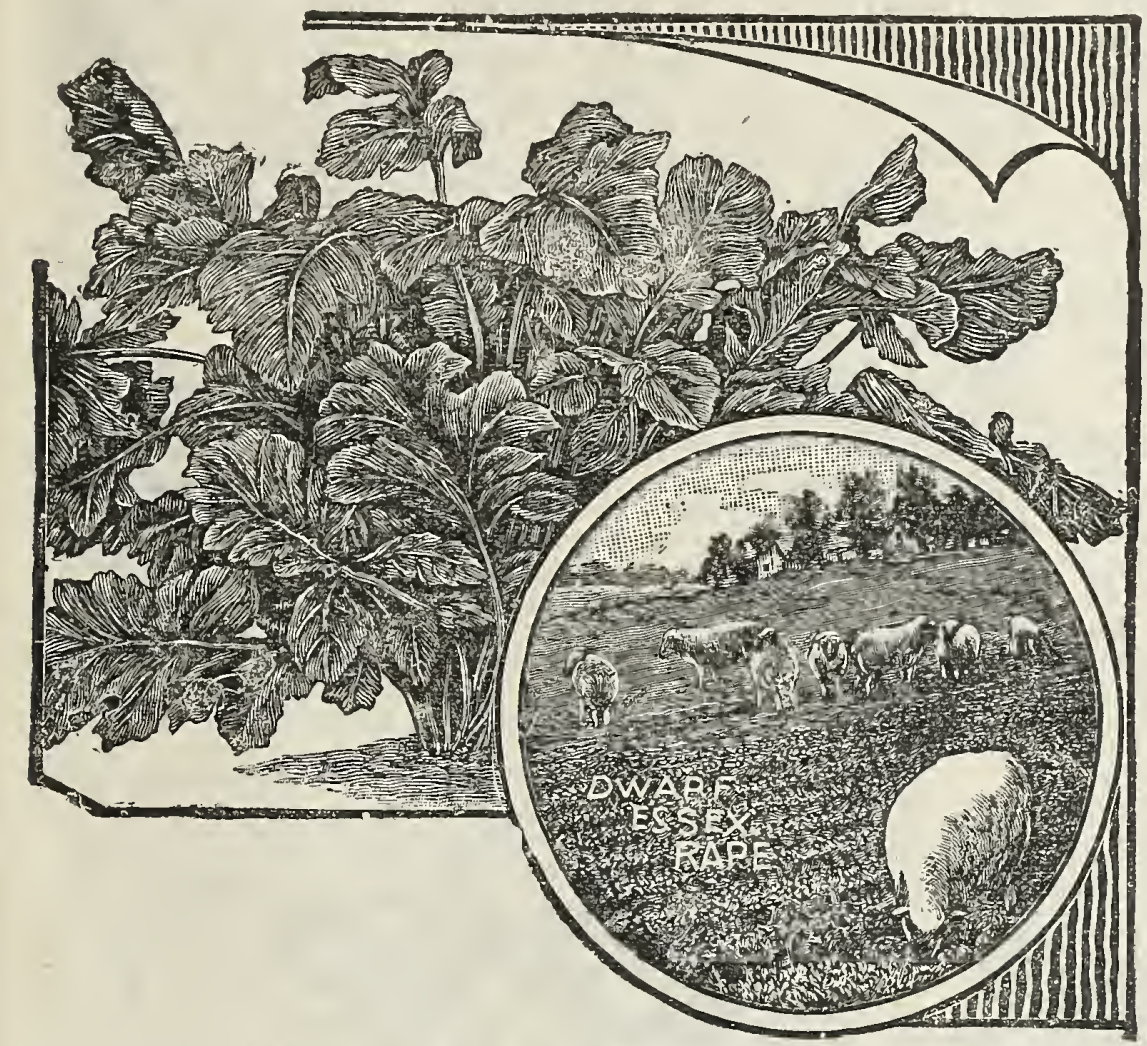

Siberian Millet Siberian Millet is regarded as Silo of the best varieties for eneral cultivation in the western states. It matures about the same as Common and Hungarian Millet and, has been successfully grown in sections where the season is too short to mature a corn crop. Probably no variety of millet produces a heavier yield, or better quality of hay. Its abundant growth, combined with a leafy character of stalk and drouth resistant qualities, has brought it into high favor among stockmen in the northwestern states. Bu., \$3,00. See Blue Price List.

Japanese Millet Entirely distinct from all 3 to 5 feet high, stands up remarkably and yields enormous crops. When cured it makes good hay and in quality is superior to corn fodder. It is relished by all kinds of stock. It may be sown broadcast at the rate of 15 lbs. an acre, but it is better to sow in drills 12 to 18 inches apart, using 10 to $12 \mathrm{lbs}$. to the acre. Cultivate until the plant is 18 inches high, when its rapid growth will smother all weeds. It does best on low, moist ground.

$$
\text { See Blue Price List. }
$$

Hog or Broom Corn Millet This is grown purpose for which other Millets are sown, and makes fair hay if cut very young. It, however, yields enormously of seed, even 60 to 70 bushels to the acre. and this seed is very advantageously used for fattening swine and other stock, and is of special value for this purpose in sections where corn cannot be safely or cheaply grown. Seed also makes very fine feed for poultry and young chicks. It is very similar to the Farly Fortune Millet, except that the seed is yellowish white in color. it will mature in about two months from sowing the seed.

See Blue Price List.

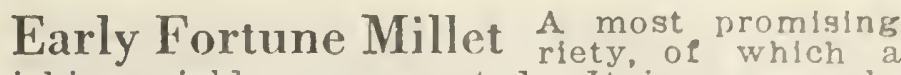
ishing yields are reported. It is very early, and is claimed to be rust proof. The seed is very beautiful and distinguish in appearance and is of the size of Golden Millet. This variety heads in from 25 to 35 days. It gives a large yfeld both of seed and fodder. It can be fed to horses and other stock without injury, even when the seed, has formed. The seeds

riety is similar to Hog Millet except for the color of the seed.

BAGS EXTRA.

Bags with Millet...... Feterita Milo iaize ind

Bags with Cane, Kafir, Feterita, Milo Maize and Sudan Grass

\section{Dwarf Essex Rape}

Dwarf Essex Rape has been usually grown, until recent years, to furnish pasture for sheep and lambs, but it is now kinds of stock.

Under average conditions a yield of from 10 to 20 tons or more of green forage per acre may be expected. According to a recent government bulletin, one acre of Rape with grain will fatten 20 wethers in two months. the same time.

the same time. in leaf and. stalk to the Rutabaga, but both leaves and stalks are more numerous in the Rape plant, and of a taller habit of growth. It is a pasture plant which may be eaten off nently fitted to furnish pasture for sheep, cattle and swine.

catte and siom 8 to 12 inches high when stock is first turned in and it ought to make growth enough to support at least ten sheep per acre during the growing period of the the standing roots when the live stock is removed, and may be repastured later. Successive sowings, made three or four weeks apart until July 1st will give a very satisfactory until July 1st, will give the entire Summer. feeding crop throughout the entire summer. seed per acre in the Corn field at the lasi cultivation or before, allowing hogs to pasture the Corn and Rape together. This makes the cost of growing the Rape

acre and nets splendid returns.

Japanese Buckwheat The Japanese is the and decidedly the most prolific variety in cultivation; produces the finest flour and is a week earlier than Silver Hull. From $1 / 2$ bushel of seed sown a crop of 40 bushels has been harvested. In color the grain is a rich dark brown. See Blue Price List.

Silver Hull Buckwheat A standar.d, variety gives excellent satisfaction. Our Dakota seed produces enormous crops of 38 to 40 bushels per acre, wheat. The flour is whiter and more nutritious.

Canada Field Peas, Yellow No other grain can be devoted to so great a variety of uses. The grain is possessed of a relatively high feeding value and the same is true of the straw. As a pasture for certain kinds of live stock

There is no kind of live stock

which Peas cannot be fed with positive adrantag

They make a good food for horses at work, and colts during the period of development, if given as cattle, Peas are probably unexcelled.

Peas furnish a good food for milk coms. They have been found peculiarly beneficial for building up dairy cows when "out of condition taining them in fine form, and they are also excel oats and bran to cows in milk, they may usually form one-third to one-half of the grain portion by weight.

Peas are superior to corn for pigs at any time prior to the fattening season; hence they mas be 
fed to them more freely, but in no instance should they form the sole ration before the finishing period begins. During the fattening period, Peas are unexcelled when fed as the sole grain food. They promote growth, while they fatten in excellent form, and they furnish a sweet, firm and excellent quality of pork.

Along with oats, in, say, equal parts, by weight, Peas make good, grain ration for ewes in milk and also lambs, more especially when the latter are for the early market. When sheep are being fattened for the block in winter, no grain food can be fed which will be found more suitable than Peas and Oats.

The quantity to sow per acre will vary from $1 \frac{1}{2}$ to 2 bushels.

\section{See Blue Price List.}

Cow Peas Northern Grown. Furnishes good pasbe used for soiling or hay, but for the two purposes last named it is a little difficult to handle. It has great power to enrich the land by putting in it nitrogen drawn from the air, and since it may be grown as a catch crop, an immense future lies before it in enriching the soils. When pastured by cattle, the early pods should be well formed, before turning in the stock. When pastured by swine, the crop should be allowed to get nearly ripe. should be done when the plants are in full bloom.

Cow Peas are usually sown broadcast at the rate of 4 to 6 pecks per acre. When drilled, 2 to 3 pecks are usually sufficient when the rows are far enough apart to permit cultivation.

\section{See Blue Price List.}

Soy or Soja Beans Northern Grown. Valuable for hay or soiling feed for They hogen manure. They resere appearance. Like clover they are great soil enrichers, gathering in nitrogen from the air and storing it grown wherever Corn will ripen. The Northern grown Beans are hardier and mature earlier than the Southern ones. They should, be planted after Corn in rows $2 \frac{1}{2}$ feet apart with 6 to 8 plants to the foot of row if grown for the beans, requiring about $1 / 2$ bushel of seed per acre. When grown for hay, it is preferable to plant the rows closer together or sow broadcast at the rate of $40 \mathrm{lbs}$. per_acre.

\section{Hairy Vetch}

Sometimes called Winter or Sand Vetch. This is one of the bes't annuals grown for stock feed, soil improving purposes, and as a cover crop in orchards If used as a soiling crop, an acre of vetches seeded with Oats, Rye or Winter Wheat, will yield six to eight tons of green fodder, which is readily eaten by all kinds of stock.

It will grow in almost any well-drained soil, and is especially suitable for sandy soil. The seed-bed should be clean, firm, moist and well-pulverized.

Hairy Vetch is usually sown from about the middle of August to the first of October; or in the spring from the latter part of April to the middle of May. It may be sown broadcast or with a grain drill at the rate of one to one and one-half bushels of seed per acre. Less seed will be required if drilled. The seed should be covered about the same depth as grains.

A bushel of Rye, Wheat or Oats per acre is usually sown with one bushel of Vetch, so as to furnish a support to keep the vines off the ground. The vines are very difficult to cut when sown alone.

Vetch should be cut for hay when the pods are half formed. It may be cut for green feed at the time it is in full bloom.

\section{Kherson and Sixty Day Oats}

Kherson and Sixty Day Oats are very similar and perhaps identical, so that the same description may be applied to both.

Their growth is vigorous but not rank; the plants being slender and strong, and of average height. The panicle is open, medium in size, bearing from 25 to 50 spikelets. The kernels are small to medium in size, slender in shape but plump and thin hulled, making them very meaty and very heavy per measured bushel. The larger kernel in the spikelet at times bears a short weak awn. The color of the grain is from a pale yellow or almost white to a deep yellow, the intensity of color varying with weather conditions. They are among the earliest oat varieties known, usually maturing in 70 to 90 days from the date of seeding.
An early maturing grain has more assurance of escaping rust and drought or frost in northern latitudes that often come before later maturing grains are mature.

Because of their early maturity and rather scanty foliage, they are particularly suitable to use as a nurse crop for grass and clover.

These oats are more adapted to low, rich ground than most varieties, for they have a less tendency to rust or lodge. There is probably no other known variety of oats so suitable to such a wide range of soil and climate and still remain productive.

Comparative yields with other varieties over a period show the Kherson variety to be somewhat higher.

\section{See BIue Price List.}

\section{Swedish Select Oats}

Swedish Select Oats was introduced by the U. S. Department of Agriculture from the Moscow district of Russia in 1899 and distributed among the U. S. Experiment Stations. It is a typical white oats with a long spreading panicle, kernels large, plump and heavy. The larger kernel in the spikelet usually grows a strong, twisted, black awn. During favorable seasons the weight per measured bushel is very high. It is a strong grower with broad leaves and stiff, tall straw, growing somewhat coarser than the Kherson and yielding more straw to the acre. This oats is a later maturing variety, requiring $10 \mathrm{C}$ to 115 days to mature from the date of seeding. It is popular for its stiff straw and drought-resisting qualities and its splendid ability to grow on soils of medium fertility so prevalent throughout the northern states. Its strong, dense root system enables it to resist considerable drought. It is also a valuable variety of oats to grow under irrigation in the Rocky Mountains and Pacific Northwest regions. It is an exceptionally good yielder of grain and produces a fine quality of straw desired by many farmers. On rich soils or during favorable conditions this variety has a tendency to lodge, although not to any greater degree than many other varieties.

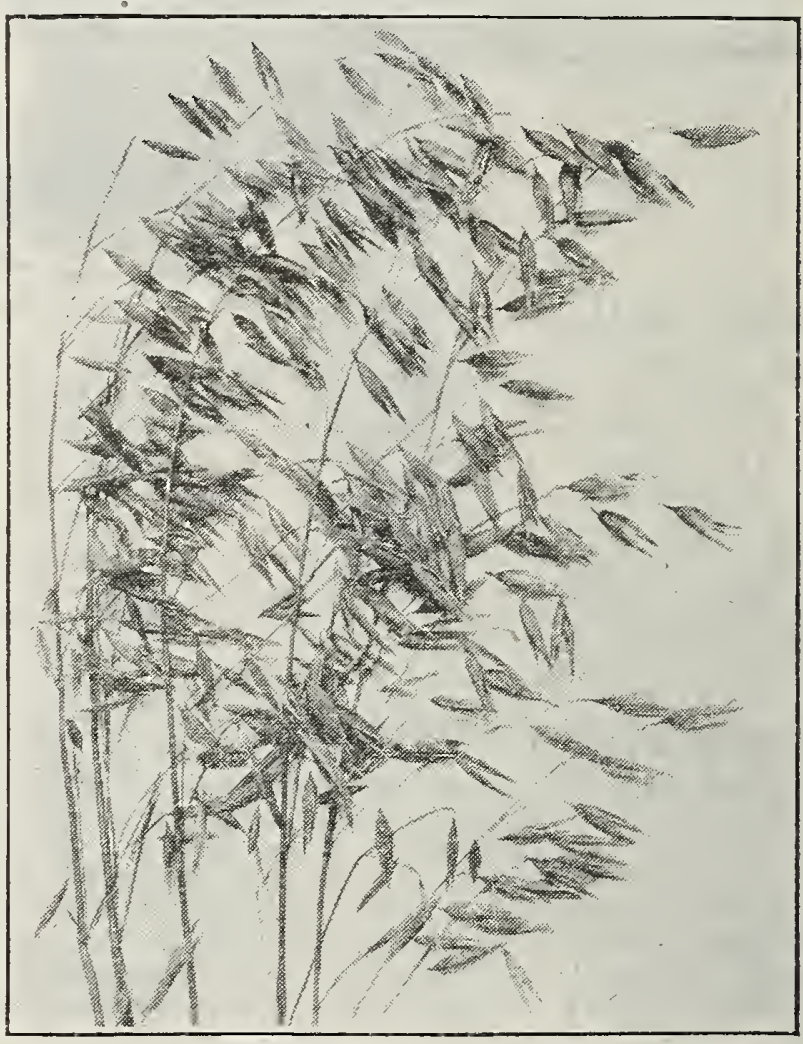

Swedish Select Oats.

Loebs Northern Grown Seed Barley o u r is as fine as is obtainable. A splendid six-rowed barley, which has been grown in Brown county for several years and is now one of the most reliable varieties of barley grown in large quantities. It varieties of barley grown and strong bearing long. is early, very vigorous and strong, well-filled heads of plump grain. The strong root and long, stiff straw have been characteristic of satisfactory.

Seamless Grain . ....................65

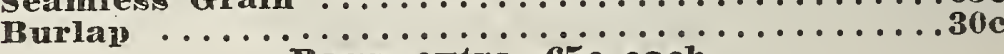




\section{Speltz or Emmer}

Speltz has now been grown in the United States in a large way for several years and each succeeding season not only emphasizes its value, but sees its production increasing to an enormous extent. It is found to be adapted to a wide range of soil and climate, to resist extremes of weather, to be of excellent feeding value and to yield so much more heavily than oats and barley as to insure its more heavily than oats and barley as to insure its the leading and standard cereal crops of the world. Those who have not grown Speltz should not let another season go by without giving it a place and an important place, too. on their farms.

It is readily eaten by all kinds of stock and has shown itself to be especially adapted when fed to milch cows. It is better to mix it, however with bran and shorts, as it is a pretty heavy feed when fed alone. As a swine feed we think very not quite equal to oats, it makes a fair horse feed.

Its most striking value is found in its droughtresistant qualities. Drill two bushels per acre. Forty pounds to the bushel.

\section{See Blue Price List. \\ Seamless Grain, 65e; Burlap, 30c. \\ Loebs Northern Grown Seed Potatoes}

Wisconsin Pedigree Barley is a selection brucker and comes from the foremost state in the Union in the production of barley. It is the result of many years' selection and breeding, starting with a single perfect stalk. In yield it averages 15 to 20 bushels more than other sorts and the quality is unequaled. The long, large heads are completely filed out. The coior is brighter and whiter than any other barlej now on the market. Another important matter is that the kernels are all uniform in size, plumpness, culor, etc., and near ly always overruns in weight. It is a most vig orous grower with tall, strong straw which stands up better than any other. Every barley grower should hasten to get a start with this new and coming variety.

\section{See Blue Price List.}

New Russian Flax More attention should be seed, as it is such an importan item while you raise flax you might just as well raise the very best, so you will not have to stand a dockage of 10 to 15 pounds per bushel for foul seeds, such as wild mustard, barn weed and wild buckwheat, so commonly found in flax. What we offer is nice, clean, healthy seed, grown on new land. Write us for prices when ready to buy. Ask for sample.

$$
\text { BAGS EXTRA. }
$$

No potatoes grown can be compared with those produced in the North, either for vigor and freedom from disease or producing and long-keeping qualities. A barrel of potatoes is sometimes an unknown quantity. Our barrels contain a plump three bushels.

\section{Loebs Extra Early Ohio Seed Po-}

tatoes This grand, old and reliable poa lengthy tato is too well known to require er and potato it a trial, and where the true and genuine stock was secured, it has always given the best of satisfaction. No matter how many new early varieties are introduced, the Early Ohio is still the leading market potato and as such we place it at the head of our potato list. If you want early potatoes, don't forget to add some of these to your order, as they will go fast at the prices we have on them. Carloads of this standard early variety are shipped every year to the southery states for seed poback again to our largest. potato markets in the eastern and northern states. where it naturally spuils the market for the home-grown potatoes. The southern potato grower realizes that by planting our extreme Norther: Grown Early Ohio, he will have his crop at least ten days to two weeks earlier ready for the market than if he would plant his own or more than if he would plant his own or more Grown Early Ohios are vigorous and healthy, will naturally produce the largest crops and mature almost two weeks earlier than such as are bought up by seed dealers in larger cities, who pick them up in the open market, as long as they have a reddish color and an oblong to an oval form, and call them "Early ohio." Write for

\section{Loebs Earliest Six Weeks Market Potato} It grows medium to large, oblnng to round shape, a light, flesh-colored skin, white flesh, very smooth eyes even with the surface; tubers grow close together in the hill. The potatoes begin to form when the vines are only four or five inches high. Our "Early Six Weeks" is a drought resister. Why, farmers, if you want the surest potato for a dry climate, you want some of our "Early Six Weeks." They will please you and make you money. Try them. Write for prices.

Important Potatoes are forwarded by express livered to the treight as directed, and are depacked; after that our responsibility ceases. Purchasers take all risks from freezing or heating. No charge for barrels or cartage to depot.

Quality of Our Potatoes We send out only potatoes and do not handle seconds at all. 


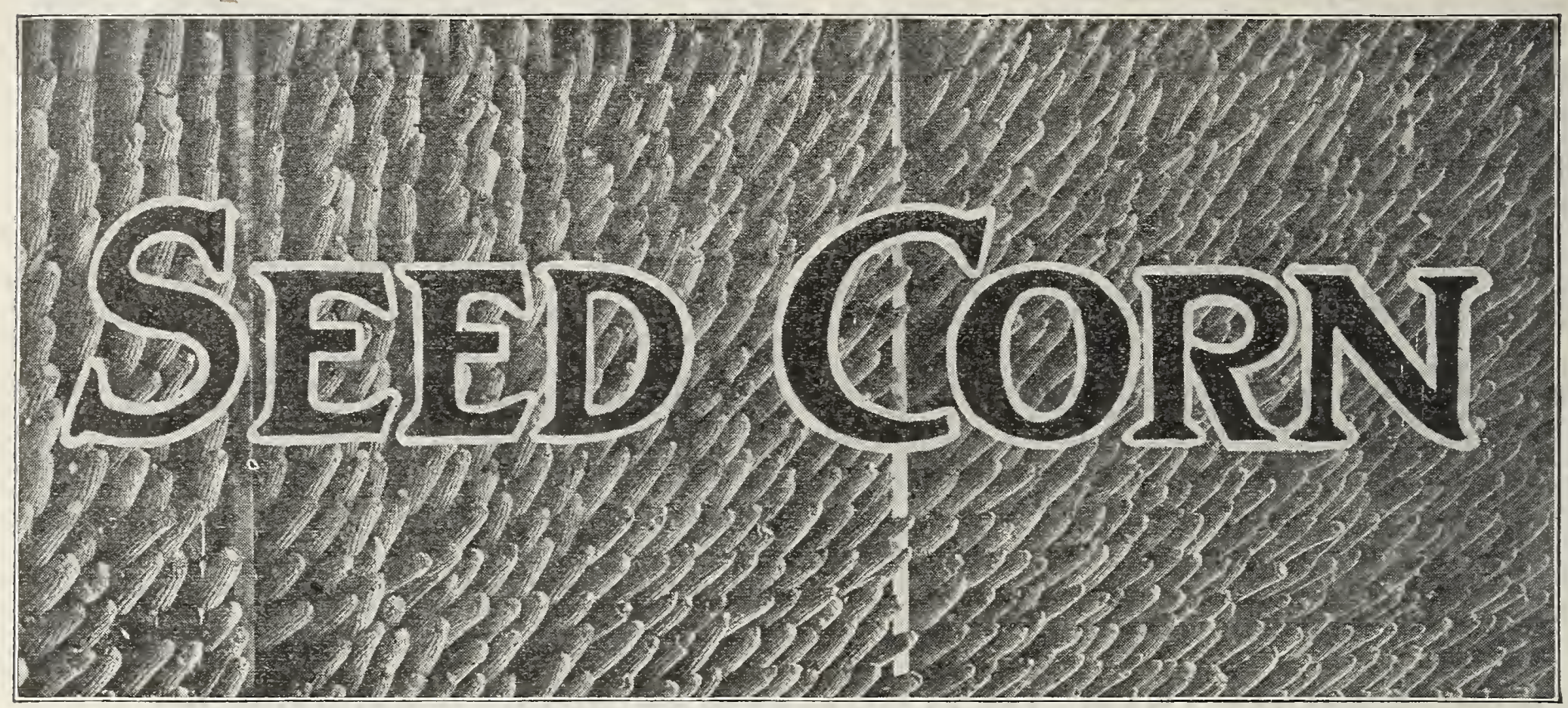

\section{DON'T PLANT “JUST CORN” PLANT SEED CORN}

\section{SATISFACTION GUARANTEED OR MONEY REFUNDED}

On arrival of seed corn examine it, test it, have your state or United States Department of Agriculture test it, and if not satisfactory, or if for any reason you do not wish to keep the seed return them within ten days and we will promptly return your money. This guarantee holds good on any seed corn, clover, grass or other seeds purchased of us. Could you ask any fairer offer?

\section{DAKOTA GROWN SEED CORN}

All our corn listed on the following pages was grown for us right here in Brown county, South Dakota, with the exception of our Southern Fodder.

We have the choicest and finest varieties of seed corn this season that we have ever handled and we have been in the seed corn business for 23 years.

Just a few words in regard to the manner in which we handle such large quantities of corn. Our corn storage building, which is 50 by $100 \mathrm{feet}$, is extremely well ventilated and is kept at an even temperature (well above freezing) all winter, which assures us that our corn is never touched by frost after it has been placed in the cribs. Here the corn is sorted and constantly tested to make sure that every bushel of corn that we send out is of satisfactory germination.

As you well know, last spring was a very critical season for seed corn. However, we were more than pleased with our corn room, as our corn retained its high germination from fall until spring. People who have visited our corn room give us credit for having the finest corn room in the Northwest and they assure us that our efforts toward putting out good seed corn are heartily appreciated.

No matter how much moisture corn contains, there is no danger of the vitality being weakened after it has been placed in our corn room.

You will find it very interesting and well worth your time to inspect our corn room and see how the corn is sorted, shelled and graded.

Of course we would like to have your orders, but whether we get them or not. we invite you to come in and see our stock. We are here for service.

Each year farmers in this locality plant corn that fails to mature simply because they plant corn imported from a southern locality even though it may have been less than 50 miles distant and was not acclimated. Soft or immature corn has not as high a feed value as thoroughly matured corn. Why not overcome this difficulty by ordering home-grown seed corn from us? The seed we offer is selected, not overcome this difficulty by ordering home-grown seed corn from us? The seed we offer is selected, tainable.

This spring more corn than ever will be planted because doubting farmers have seen with their own eyes that it pays to plant corn.

Secure your seed corn early; don't wait until planting time and then be obliged to get your corn planted late or fail to get the variety you wanted. Ask to see our corn and the methods we use in drying it. We are'always ready for inspection. 


\section{The Wonder Corn of the North.}

\section{Minnesota No. 13}

Farmers living in the latitude of central Dakota will find this variety superior in quality and productiveness to any other they can plant. It is rightly named-for the results that corn growers in the North and Northwest secure from it year after year are assuredly womderful.

Minnesota No. 13 is an early maturing-100-day-yellow corn, famous for big yields and hardy adaptability to a great range of soils and climatic conditions. It is enormously productive and more dependable in most sections of the North than any other variety known. because of its big yields and early maturity. It is more quickly acmaturity. It is more quickly acwill thrive and produce heavily on soils where the other less hardy varieties entirely fail. It is an excellent fodder corn, too-stalks frequently growing to 7 feet high.

This variety is one of the most successful ones ever developed by the Minnesota Agricultural College Experiment Station. Ears average 8 inches in lengtr" and usually grow 8 inches in lengtr and usually grow rows of kernels growing compactly from butt to tip of each ear, and the color is a rich, bright yellow. Kernels are wedge shaped and the ears are almost invariably well filled, and the individual kernels plump and well colored. No corn makes a better appearance or excels Minnesota No. 13 for quality.

We are offering the very highest quality of Minnesota No. 13 Seed Corn this season, and advise our customers to order early. Price, shelled and graded, bu., \$3.75; ear corn, bu., \$4.00.

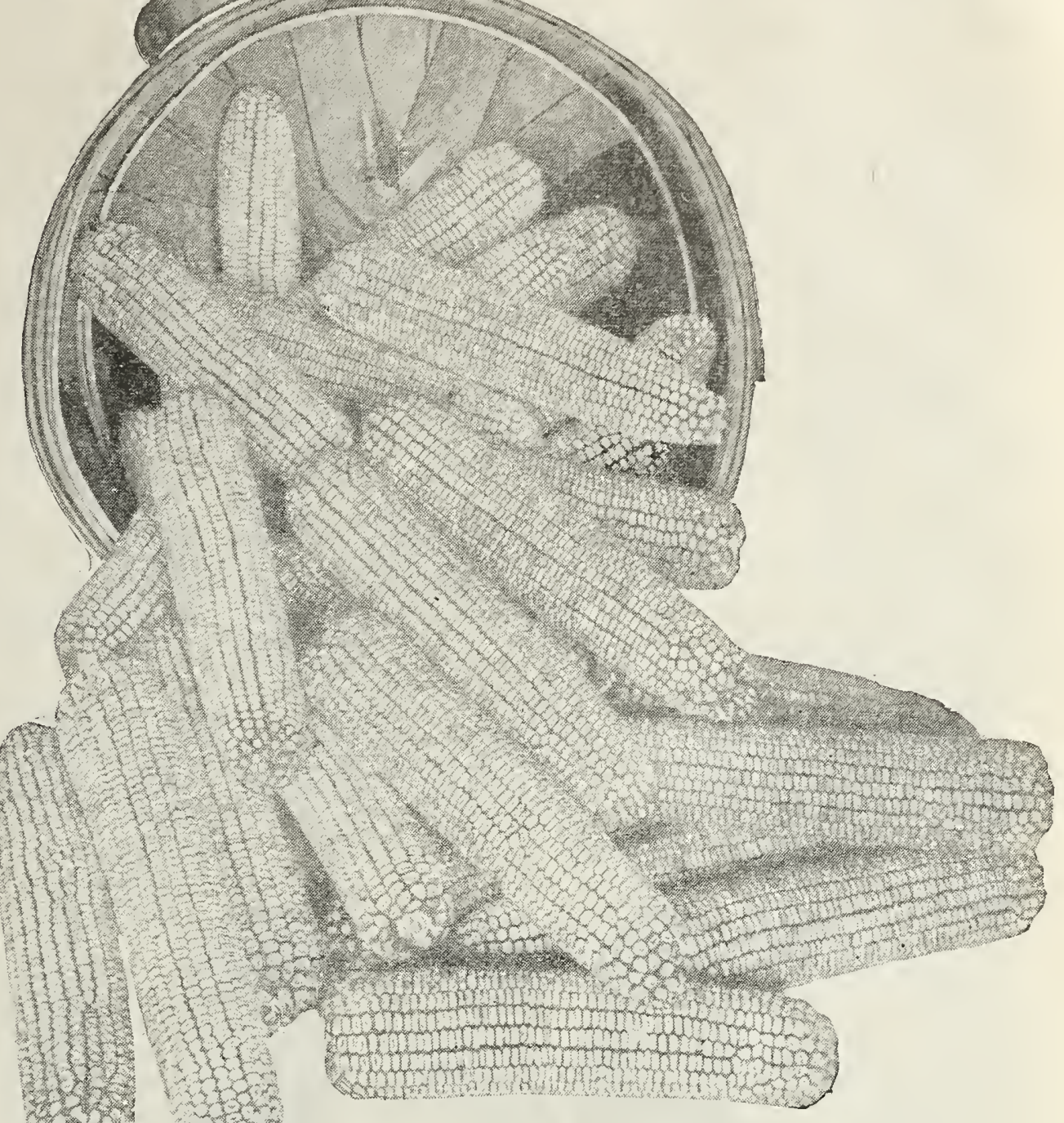

Pride of the North Although this is an old been originated here in the Northwest, it is hard to beat as an early, good yielding variety of corn, as it is one of the earliest of yellow dent corns, maturing here in the Dakotas in 80 days, and even ripening in this northern latitude if planted as late as the first of June. The ears are 6 to 8 inches long, with small cobs and very long and deep kernels, which are of a very uniform, bright orange color. Seventy pounds of ear will make 60 pounds of shelled corn. The stalks grow only to a medium height, and are very leafy. You will make no mistake in planting Pride of the North. Prices: Bu., $\$ 4.00$, shelled and graded; $\$ 4.25$ per bu. on ear.

\section{Gold Coin Corn or Brown County Yellow} Dent The earliest, hardiest and most drouth-reDistant dent corn. No corn has given better satisfaction or yielded better grain than this
justly celebrated variety.

This wonderful variety has gained great favor among the corn growers everywhere. The large amount of corn produced on so small a cob suraccurate idea of this wonderful corn.

It is what you have been seeking. It is all corn. It is early. It is prolific. It has strong, stiff stalk and stands up well. It will outyield any other early corn. It has the smallest cob of any large grain. Is rich in oil. It will fatten faster and tops the market. It takes first prize wherever shown.

The best up-to-date corn in existence. Its broad, closely-set leaves make it a valuable fodder corn. It will please you, and it's the corn you want. We want every farmer to plant this wonderful corn, and we have put the price in reach of all. We believe that this corn planted in the northern part of South Dakota or in North Dakota is as safe a proposition as anything in the way f of corn that grown has been grown continuously in Brown county for the past 18 or 20 years. Our stock is very good. Prices: Bu., \$3.75, shelled and graded; $\$ 4.00$ per bu. on ear.

BAGS EXTRA.

Seamless Grain, 65c; Burlap, 30c.

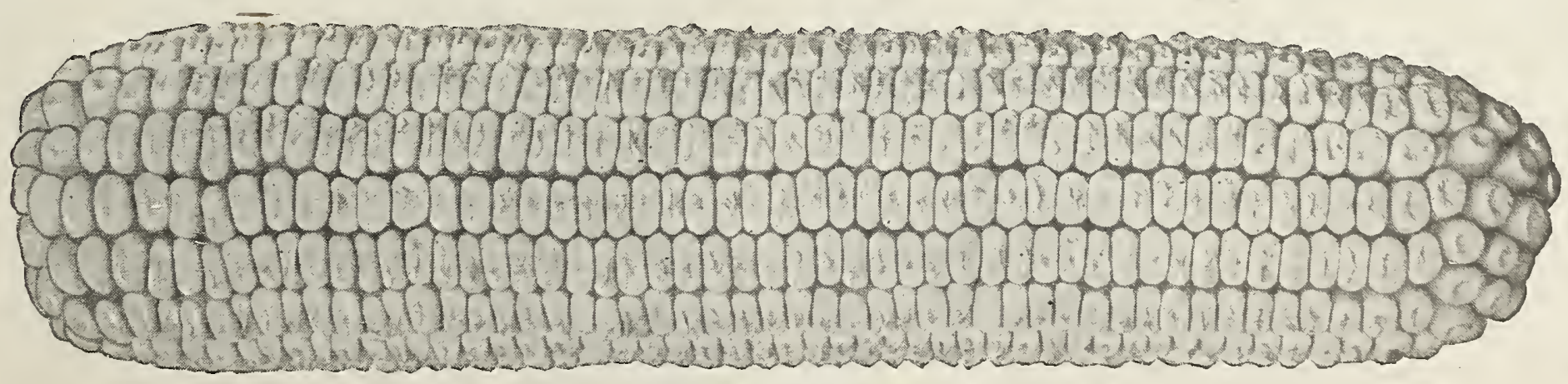

Gold Coin Corn. 


\section{RUNTE'S WHITE CAP YELLOW DENT}

\section{THE BEST CORN FOR NORTHERN LATITUDE}

Runte's White Cap Yellow Dent is so well known to corn growers in northern South Dakota, Montana and Minnesota as to need little comment.

It is hardy, vigorous in growth and under ordinary climate and weather conditiohs can be depended upon to fully mature and yield big crops. Runte's White Cap Yellow Dent will mature in 95 to 100 days. The ears average about 9 inches long and kernels are especially deep, and the cob unusually small. Ears have 14 to 16 rows of kernels and the kernels grow so compactly that the corn shelled off the cob will acrually occupy more than corn and cob before shelling.

This wonderful northern grown corn was developed by Messrs. Chas. \& Ed Runte, who have won national fame as corn growers and were the first men to introduce and grow this variety in this state.

Starting in 1908, these progressive corn growers, through careful selection and culture, succeeded in producing a strain of White Cap Yellow ceeded in producing a strain of White Cap yellow conditions, with vigorous stalks, even ears, compact, deep kernels and uniformly classy appearance. This corn was introduced by them in North and South Dakota, Montana and Minnesota under the name of Runte's White Cap Yellow Dent.

Few if any men in the Dakotas have done as much for the corn industry as the Runtes, who are credited with growing the finest and best corn for the Northwest.
By the introduction of Runte's White Cap Yellow Dent Corn in Brown county the corn crop of this county was increased 12 bushels per acre for the county within a period of 5 years.

Runte's White Cap Yellow Dent outyields all other northern varieties. If you are looking for a corn that can be depended upon to grow and mature in the latitude of North and South Dakota, Minnesota and Montana, we strongly recommend Runte's White Cap Yellow Dent, which has proved its worth through many years and has been a continuous and dependable crop yielder and money maker for thousands of farmers. There is no other corn that will take its place in this latitude.

For more than 12 years the White Cap Yellow Dent has been grown for us by Chas. \& Ed Runte in Brown county, South Dakota-our own home county.

This announcement alone will, we believe, bring us enormous orders from farmers who have learned by actual experience to make Runte's White Cap Yellow Dent their standby. No other variety of dent corn will equal this variety for ields and feeding value.

Don't take chances, but send us your order at once, for we offer subject to unsold the original Runte's White Cap Yellow Dent grown from genuine Runte's seed and carefully tested and in every respect the highest grade of seed obtainable in this wonderful deep grained corn. price: Per bu., \$3.75, shelled and graded; $\$ 4.00$ on ear.

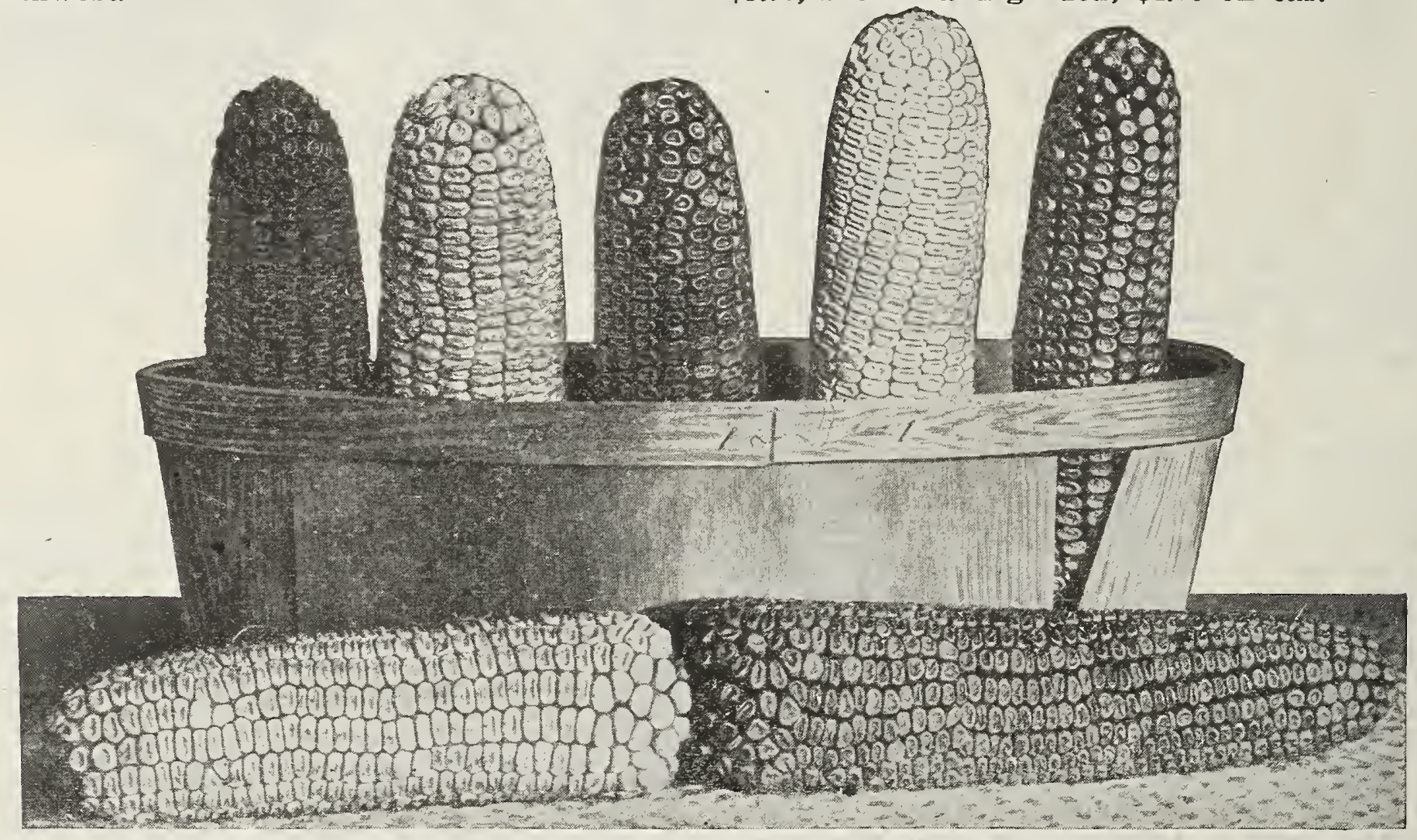

Runte's White Cap Yellow Dent.

Northwestern Dent Corn Also called Bloody mature in from 70 to 80 days withutcher. It will This is a very distinct and handsome variety, the exposed surface of the kernels being white and the sides of a pretty cherry color. It is large eared, 12to 16-rowed, with large deep kernels and a thin cob. This corn has been originated here in the Northwest and although it is such a heavy yielder, generally producing from 75 to 80 bushels per acre, it matures here in the Northwest in 85 days. The average height of the stalks is from 6 to 7 feet and ears set about $21 / 2$ to 3 feet from the ground. It produces a large crop of corn and fodder at the same time. This corn is in great demand in both North and South Dakota, as it is so early and hardy. Northwestern Dent has been grown in the Northwest with great success and complete satisfaction. Many stalks have two good ears. We will send samples of any corn upon request. Prices: Bu., $\$ 4.25$, shelled and graded; $\$ 4.50$ on ear.
Silver King Corn This corn was originally obexperiment station and by a careful selection of the best and earliest ears we now have a White Dent Corn with large ears, small cob and deep kernels that is sutied to our Dakota conditions. The ears of this corn average 8 to 9 inches in length and are always well filled out to the tips. As a yielder it has no superior. An average yield for this corn of 10 bushels per acre more than any other sort, and yields of over 60 bushels have been reported. These are remarkable yields when taking into considera. tion that the average crop of corn in Dakota is only about 35 bushels per acre.

In general there is not the demand for White Corn that there is for yellow. This is largely a matter of prejudice as they are practically the same feeding value. We urge the general growing of this splendid Corn. It is a first-class variety for general farm use-as a grain feed, for ensilage or forage. Prices: Bu., \$3.75, shelled and graded; \$4 on ear.

BAGS EXTRA. Seamless Grain, 65e; Burlap, 30c. 


\section{Farmers' Surprise or \\ White Dent Corn}

Ripens with Northwestern Dent. This early White Dent, 12 to 14 rows, has stood the 12 to 14 rows, has stood the the only corn outside the Northwestern Dent that can show such a record for early ripening, great yield and, compact growth of ears. It is one admirably adapted to a northadmose wishing a ern climate. first-class white corn will find in the Farmers Surprise a hard corn to match. This is a for We claim, and all customers who have crown it the past ten years grow can prove, that the Firmers Surprise is the hardiest and most reliable Dent Corn to five days and produces just as much, if not more, than much later maturing kinds. Reliability is stamped upon every feature of this corn. As it is such a strong grower, sending its roots deep into the soil, it will produce a paying crop in most any locality where other varieties would not gather nourishment enough to grow a fair-sized stock much less to mature an ear. The Farmers' Surprise is of a very distinct type, as our cut also indicates, the ears being symmetrically formed, long, straight and tapering to a point at once. The grain is of medium depth, compact and heavy, and the ears medium to large, averaging about 5 to 7 inches. The stalks grow only jointed, and produce an abundance of fodder. We have a good supply of this variety this season.. Prices: Bu., \$3.75, shelled and graded; $\$ 4$ on ear.

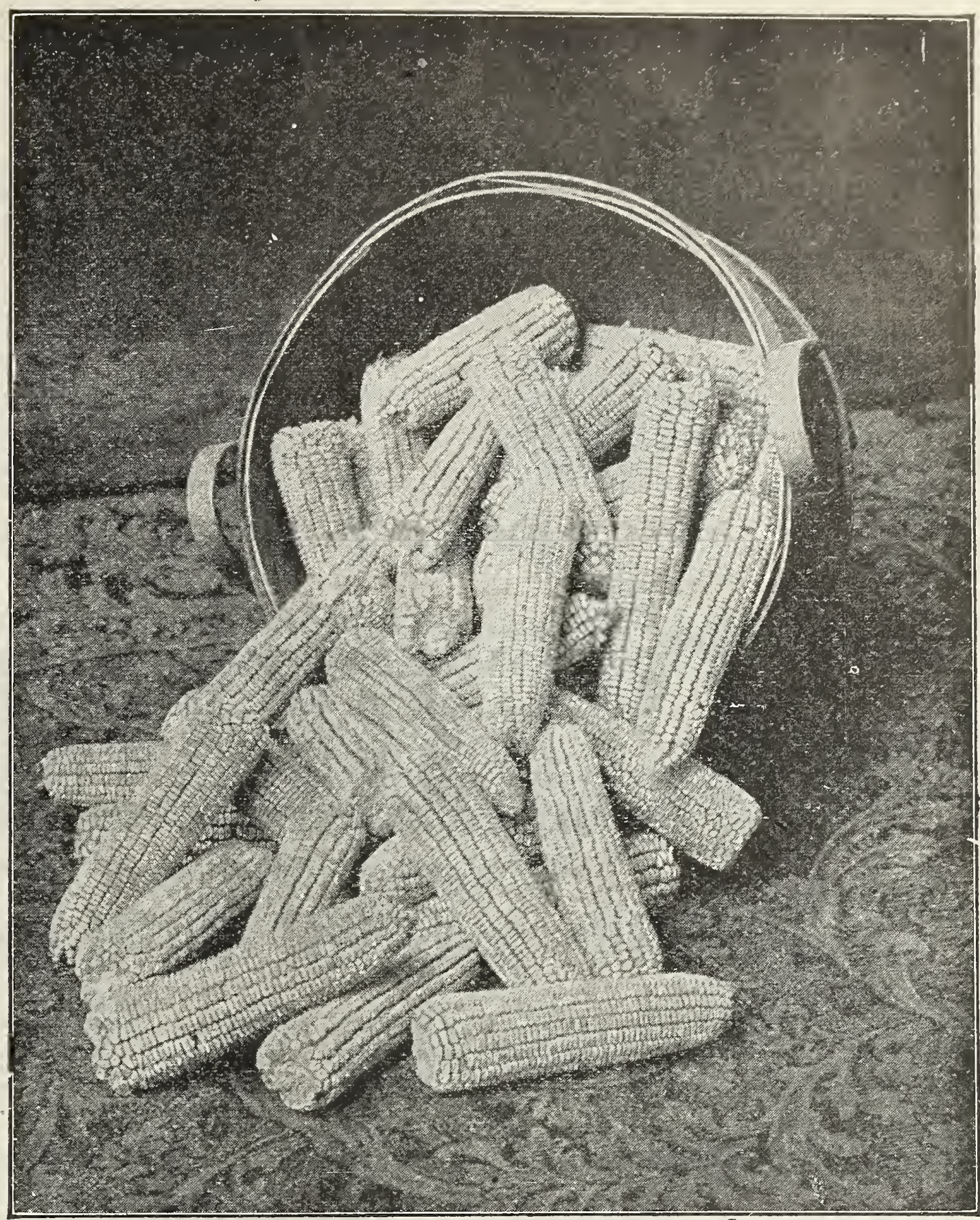

\section{Rustler White Dent}

Reputed for Its Extreme Earliness. Recognizing the invaliable relationship between the type grown and the ripening season we unhesitatingly recommend this variety for its reliability as an extremely high-yielding Corn in districts throughout the Northwest where ninety-day corn is an absolute essential.

This variety originated many years ago in South Dakota and is largely grown in our northwestern states. Matures in 90 to 95 days. Our stock has been selected for earliness and consequently we have sacrificed size for an earlier strain of this variety. Actual measurements of our stock of this variety. Actual measurements of our stock circumference of trifle less than $6 \frac{1 / 2}{2} 14$ to 16 rows For the same localities suitable for planting Min. nesota No. 13 our Rustler White Dent can be plant ed. Price: Bu., \$3.75, shelled and graded; $\$ 4$ on ear

Loebs Squaw Corn "Squaw Flint. A very early kernels all colors of the rainbow. A very beautiful corn and one that is very popular for late planting It is what you might call all-purposes corn. It is fine for roasting ears; coming to that stage when early sweet corn is getting hard. It makes a fine fodder corn, as it throws out many suckers that make good-sized stalks, and each hill of this corn is literally covered with nice, long ears of all colors of corn. Stalks grow to good size, covered with nice broad leaves, and every farmer that
plants corn at all ought to plant at least a few acres of this Squaw Corn. Try it. We have a large supply this year.

$\$ 4.25$ per bushel, shelled and graded; $\$ 4.50$ on ear.

White Flint This standard variety is considered The ears lint the best flint corn on the market. handsome shape, flint length, 12 to 15 inches, and, sturdy, vigorous growth; leaves are very broad and succulent, and it is therefore of great value for fodder and ensilage, as well as for grain crops. Stalks usually bear two or three long ears. You will be pleased with it if you like ilint corn.

$\$ 4.25$ per bushel, shelled and graded; $\$ 4.50$ on ear.

Yellow Flint Resembles White Flint in earligrain is yellow. ness, habit of growth, etc., but the riety will mature in 70 to 75 days. In localities where seasons are short and nights are cool it may be depended upon to give a crop The yield must, of course, vary with conditions of soil, cultivation and, season, but it has been no uncommon occurrence to secure a yield up to 75 bushels per acre. Gives an abundance of fodder of splendid quality. Average height stalk 5 feet, average distance base of ear from ground, $1 \frac{1}{2}$ feet. Average length of ear, 10 inches. Conditions same as noted for other varieties above.

$\$ 4.25$ per brishel, shelled and graded; $\$ 4.50$ on ear. BAGS EXTRA.

Seamless Grain Burlad ............................. 
Large Growing Southern Variety of Fodder Corn

Southern Tellow Fodder Corn A tall growSolth all over the counerms to have the preference over any other sort, perhaps because it has been very widely grown and will produce a large tonvery widely grown al and very leafy. Drill $11 / 4$ bu. to the acre in rows $31 / 2$ feet apart. Bu., \$2.75, shelled and graded.

Sorlo This is a tall Southern White Fodder Corn growing leafy variety possessing the general characteristics of our Giant, but is not so closely jointed and therefore bears a few less leaves, with a corr smaller tonnage per acre. Bu., \$2.7
BAGS EXTRA.

Seamless Grain

\section{Loebs South Dakota Fodder Corn} Early Yellow Dent Fodder Corn drills, at the rate of 1 to $1 \frac{1 / 2}{2}$ bushels to the acre, this seed will give a surprising amount of rich feed, relished by all stock. It can be cut and run through an ensilage feeder for the silo just before maturity or it may be fed in the rack. Bu., \$3, shelled.

Early White Dent Fodder Corn M a y be planted the and matures at about the same time. While the Early Dent Fodder Corn does not yield so heavy a tonnage an acre, the resulting crop in most cases is of greater feeding value. Bu., \$3, shelled.

Evergreen Fodder Sweet Corn This is one of able items. The demand for it is constantly growing, and it has everywhere proved highly satisfactory. Our corn will yield a large quantity of fodder which is rich and nutritious. Valuable for feeding hogs and milch cows. Write for prices.

\title{
DON'T FORGET
}

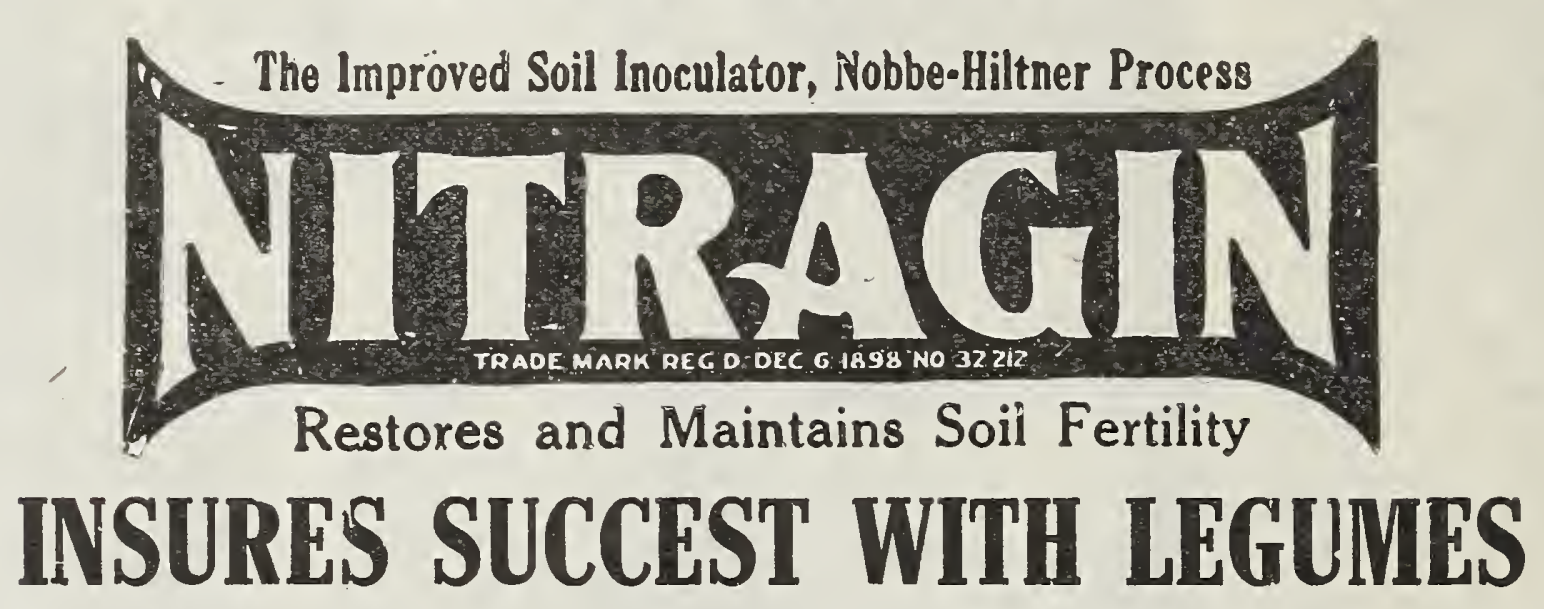

For Alfalfa, Clovers, Vetches, Cowpeas, Soybeans, Peas, Beans Carries no Weeds or Plant Diseases-Enriches the Soil -Stimulates Growth

\section{"Nitragin" Increases Yield-Makes Fertile Soil}

\section{Don't Sow Legume Seed Without Inoculation}

\begin{abstract}
"Nitragin" is the trade name of the germ that acts on the Legume root, drawing nitrogen from the air and converts it into plant food. As a result it insures a uniform "catch," quickly growing a strong, healthy, hardy plant. At the same time the soil is enriched for the nourishment of the succeeding crop. But remember, only Legumes inoculated with a good reliable culture, such as "Nitragin," will do this. Use "Nitragin" on all legumes. Make your farm fertile.
\end{abstract}

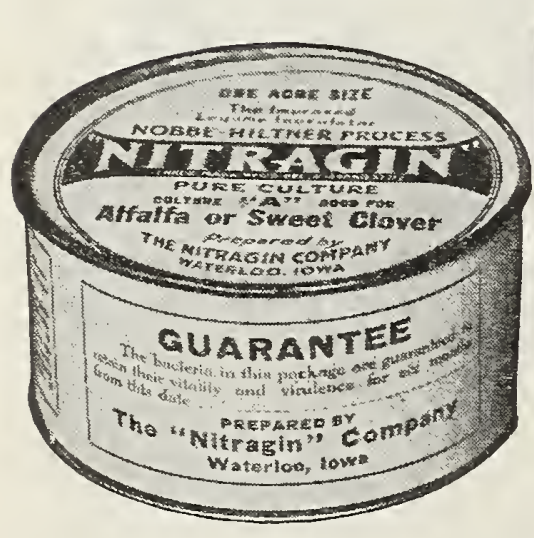

\section{Inoculate Seed with "NITRAGIN" Get a Bumper Crop}

In order to get a bumper crop your farm must be fertile. Your farm cannot be fertile unless you can grow Legumes successfully, to get a "catch," to insure an even stand, you must in a great many cases use a good, pure culture, such as "Nitragin." The pure culture system of inoculating legumes is endorsed by the U. S. Dept. of Agriculture, by experiment stations, by agricultural experts, and by farmers who have used "Nitragin." The leading seed firms through the country are also endorsing pure culture for all legumes. Science has definitely proven that certain crops must find certain bacteria in the soil or they will prove a disap. pointment or a failure. If you have failed to secure a "catch" it's because there is something lacking in the soil. The problem in a great many cases has been solved, that it lacks bacteria sufficient to insure a "catch." Be sure to state crop for which "Nitragin" is intended.

\section{PRICES}

$1 / 2$ acre size (ship. wt. 4 oz.)...\$.50 5 acre size (ship. wt. $21 / 2$ 1bs.) $\$ 4.00$ 1 acre size (ship. wt. 8 oz.) ... 1.00 10 acre size (ship. wt. 5 lbs.). acre size (ship. wt. 1 lb.) . 1.80
$\mathrm{Be}$ sure to state what crop the "NITRAGIN" is to be used for.

You can also get the special GARDEN "NITRAGIN," which is good for Peas, Beans and Sweet Peas, and large enough for the average garden, for $35 \mathrm{c}$ postpaid. Simply order: GARDEN "NITRAGIN"-35c, postpaid.
"NITRAGIN" is shipped to you by mail or express granular medium, in which the germs will live for a long time. in a ventilated can in a 


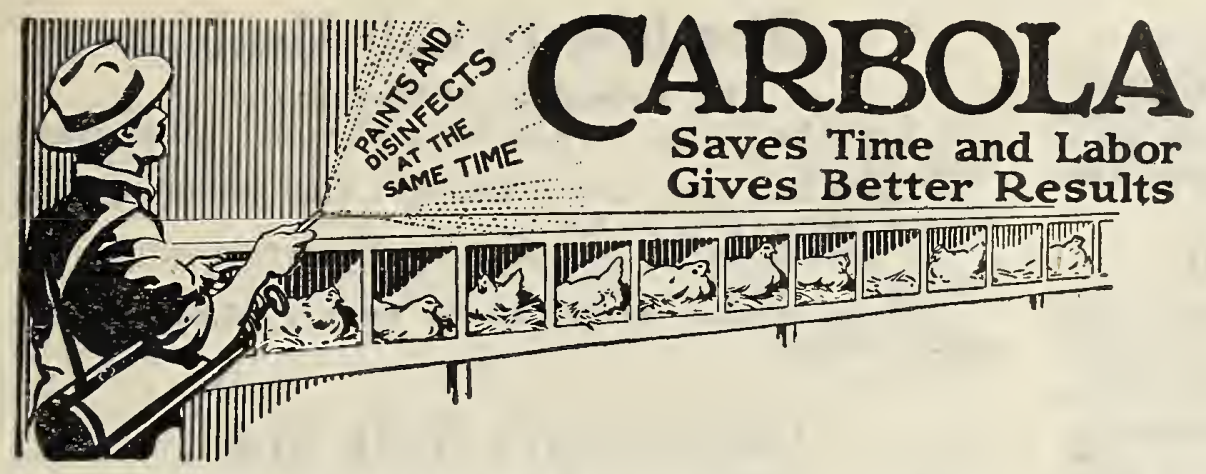

Carbola is so easily prepared and plied that you can easily keep your pou try houses, stables, dairies, cellars, thoroughly sanitary and attractive in appearance at all times.

Your money back without an argument if it is not what we claim.

10 lbs. (10 gals.), \$1.00 and yostage; 20 lbs. (20 gals.), $\$ 2.00$ and postage.

Carbola is the very best disinfectant to use in poultry houses. It kills lice, mites, fly eggs, and prevents the germs of roup, white diarrhoea, canker and other contagious diseases that affect poultry from getting a start in your flock. And it dries white-not dark or colorless-so that you make your poultry houses cheerful brighter and make your poultry houses cheerful, brighter and better looking at the same time you are disinfect-
ing without any extra labor or expense. Carbola also is unexcelled as a lice powder.

Use Carbola, the Germ-Paint, Instead of Whitewash Carbola is a mineral pigment combined with a germicide 20 times stronger than pure carbolic acid, but it is absolutely non-poisonous and noncaustic.

Carbola is ready the minute you mix it with cold or hot water. It does not spoil by standing, so can be kept on hand for use when convenient or on a rainy day. It does not flake or peel. You can apply it with a brush or splayer. Carbola never clogs the sprayer. It is used by thousands of poultrymen, dairymen and farmers in all sections of the United States and by many experiment stations and agricultural colleges.

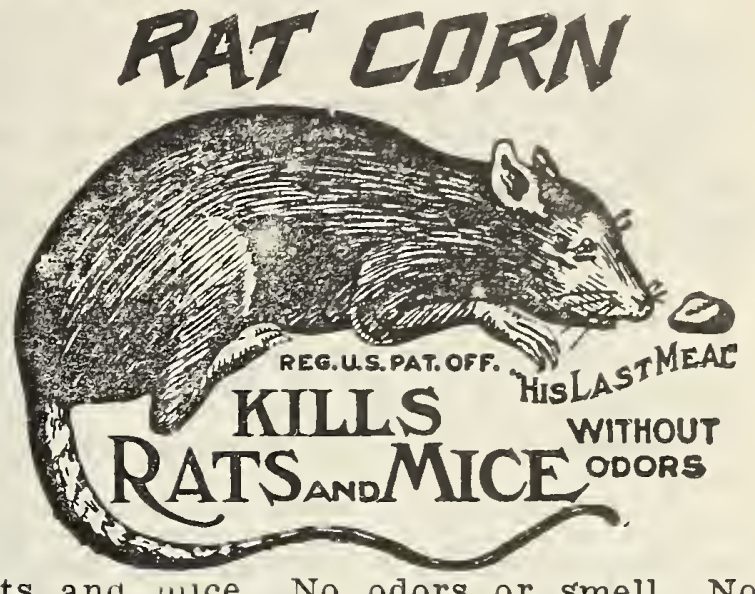

Kills rats and $111 \mathrm{ce}$. No odors or smell. No poison. It mummifies them. No matter where they die, they simply dry up. Positively do not smell.

Will not kill cats, dogs or men. without a doubt the greatest rat destroyer in the world; the only one that kills rats without any bad, dangerous or disagreeable effects.

A trial will convince you. Price: Per can, 25e and 50c. Bङ mail, 5e and 10c extra.

\section{J. L. Loebs Poultry Feeds and Supplies}

WTPRICES ARE F. O. B. ABERDEEN AND SUBJECT TO MAR KET CHANGES. SACKS FREE

\section{"Globe" Scratch Feed}

A balanced grain ration, poultry feed for grown fowls. (Strictly high grade.)

Made from wheat, kafir corn, cracked corn, barley, buckwheat, oats, grit, oil cake and Sunflower. Write for prices,

\section{"Pine Tree" Scratch Feed}

A choice feed at moderate price. Made from wheat, kafir corn, cracked corn, barley, oats, grit and Sunflower. Write for prices.

\section{"Globe" Developing Feed}

A coarse grain chick feed to meet requirements of growing chick from the time it has outgrown the "chick size" until large enough for the "Globe" Scratch Feed. Write for prices.

\section{"Globe" Chick Feed}

A complete grain feed for cinicks until 6 weeks old. Made from cracked wheat, cracked kafir corn, cracked corn, millets, hulled oats and grit. Write for prices.

\section{"Sun" Chick Starter}

A primary grain reed for baby chicks up to 20 days old. (Extra small grade.)

cracked kafir corn, for prices.

\section{Loebs Egg Mash}

High protein feed winter for layers. A ground grain mixture of exceptional merit with 15 per cent meat scraps and oil cake. Manufactured especially to meet the requirements of exacting customers, as a sure egg producer. Protein 16 to 18 per cent. Made from alfalfa meal, bran, middlings, wheat meal, corn feed meal, ground corn bran, oil cake, meat scraps. A supply should be carried at all times. Per 100-1b. sack, \$3.85.

\section{Oil Meal}

Alds digestion. It is also used in mashes. It should be fed during moulting season. Valuablo for preparing birds for exhibition. 100 lbs., $\$ 5.50$.

\section{Unmixed Grains}

We carry the following unmixed grains: Corn, wheat, oats, barley, speltz, kafir corn, buckwheat, millet, cracked corn, coarse and fine cracked wheat, sunflower seed, hemp seed, canary seed and bird rape.

These grains are all clean, sound and sweet. We do not carry burnt, damaged or musty grains. On account of the unsteadiness of the grain market we do not quote prices. Prices will be furnished upon request.

Ground oats.-An excellent food for poultry, usually mixed with other ingredients in a mash.

Corn Meal-To be used in mash. It also makes a very valuable duck feed.

Middlings.-Contains a higher percentage of protein than bran, but is used for the same purpose. try.

Wheat Bran.-Is a very valuable feed for poul-

Write for prices.

\section{Swift's High Protein Beef Scraps}

A very superior grade of meat scraps prepared in a meal suitable for feeding in mash or with other soft foods. Contains fully tein and 8 per cent fat. 10 lbs of fresh meat. Is bound to give good results. Price, 50 lbs., \$4.00; 100 Ibs., \$7.50.

\section{Darling's Meat Crisps}

Made from selected, fresh meat trimmings, carefully cooked, pressed and dried; clean and san1tary. Promotes rapid growth and makes early laying pullets. Ground in three sizes for any stage of development. Guaranteed analysis: Protein, 75 per cent; fat, $1 / 2$ of 1 per cent; fiber, not over 3 per cent. Thus 3 lbs, of these Crisps equal 5 lbs. of ordinary meat scraps. Prices 35 ekg.

\section{French's Poultry Mustard}

Is manufactured expressly for poultry use, and is different from the ordinary table mustard in the manufacture and constituents. One teaspoonful for every six fowls is the right quantity; mix it in sealed packages only. 1-1b. box, 40c. 


\section{Alfalfa Meal}

This meal rapidly mixes with any kind of mash or ground feed and can be fed to young chicks as well as older birds. Keeps them healthy and vig. orous all winter. Fine or short cut. Price, 100 lbs., \$4.00.

\section{Pratt's Baby Chick Food}

It makes baby chicks live. Makes bone and muscle. Brings along the weak ones. Prevents white diarrhoea, leg weakness, "pasting up" and other digestive troubles. Costs only a cent a chick for three weeks. Packages, 60c, 30c, not prepaid.

Just a word of caution: Do not place before the chicks at one time any more than they will clean up, and if they do not come running for their food skip a meal.

\section{Pratt's Poultry Regulator}

Pratt's is the original Poultry Regulator of America and is in use by the most successful poultry raisers everywhere.

When regularly used, hens lay throughout the year.

It will prevent chicken cholera, gapes, roup, rheumatism, expel worms, prevent.leg weakness and egg eating. It will greatly improve turkeys, geese, ducks, pigeons and guinteas-insuring quick growth and keeping them free from disease. Packages, 30c, 60c, $\$ 1.00$.

\section{Granulated Bone}

Chickens are like humans, they crave and require flesh nourishment.

Clean and sweet. Manufactured from fresh, green bone and thoroughly dried. Price, 100 lbs. $\$ 5.50$.

\section{Crushed Charcoal}

Keeps the fowls in a healthy state, purifles the blood, aids digestion, and tones up the whole system. Two sizes, coarse and fine. Price, 50 lbs. \$2.50; 100 lbs.s \$4.75.

\section{Crushed Oyster Shell}

A most important article for the poultry yard and should be supplied liberally. Superior quality. Hens will keep healthier, lay better, and eggs will be more fertile if supplied with it. 100 lbs., $\$ 1.50$.

\section{Pearl Grit}

Is the cleanest, whitest and sharpest grit money can buy. It contains a generous supply of those minerals that the laying hen needs so badly in the production of eggs, but seldom receives. 100 lbs., \$1.25.

\section{Crys-Co}

A grit and shell producer combined. It is composed of molluscan shell formation or petrified shell, crushed to the proper sizes for hens, chicks and pigeons. Contains 99 per cent pure carbonate of lime and 1 per cent flinty matter, the lime forming shell, with enough grit to grind the food and aid direstion. It makes hard shells, thus increas. ing the hens' laying power. Hens that lay softshelled eggs usually acquire the habit of eating shelled eggs usually acquire the habit of eating be largely overcome. Feed the same as Oyster Shells or grit. Price per 100-1b. bag, $\mathbf{\$ 1 . 5 0}$

As good as New Milk at half the Cost

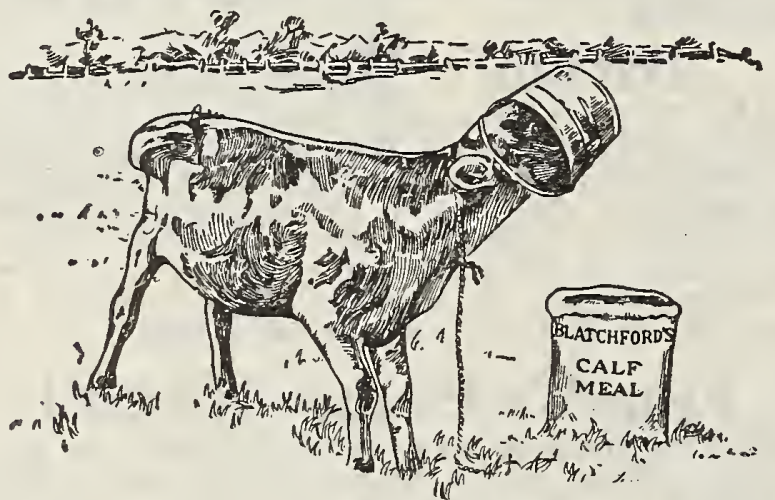

100 pounds makes 100 gallons of Perfect Milk Substitute.

Send for pamphlet, "How to Raise Calves Cheaply and Successfully Without Milk."

\section{Blatchford's Calf Meal}

The Complete Milk-Wqual.

Just the thing to raise or veal your calves right from birth.

Then sell your milk and get the benefit of the high creamery prices.

100 pounds make 100 gallons of perfect milk substitute.

25-1b. sacks, \$1.70; 50-lb. sacks, \$3.35; 100-1b. sacks, \$6.70.

\section{Blatchford's Milk Mash}

\section{Will Save Your Baby Chicks}

No more bowel trouble, leg weakness or white diarrhoea. Try a bag of this perfect milk-equal for all kinds of young poultry.

\section{GROWS-MATURES-FATTENS}

25 lbs., $\$ 1.80$

\section{From Sow to Pasture} ly on

Wean your little pigs easily, safely and cheap-

\section{BLATCHEORD'S PIG MEAT}

From Pig-hood to Pork-age it gives big bone and solid flesh. Prevents loss of growth and vitality during the critical weaning period, and always makes the runts catch up. 25 lbs., \$1.70; 50 lbs. $\$ 3.35 ; 100$ 1bs., \$6.70.

\section{Grit Boxes}

Can be used for grit, oyster shell, charcoal and beef scrap. Will not clog. Two compartments. Weight, 11/2 pounds. Price, 45c. Three compartments. Weight, $31 / 2$ pounds. Price, \$1.10. Four compartments. Weight, 4 pounds. Price, $\$ 1.40$.

Not prepaid.

Star Fountain or Feeder to Fit Mason Jars.

Will fit any Mason jar. Cheap and sanitary.

This contrivance will meet the approval of every poultryman. Being shaped like a star, it allows more chicks to be supplied than with the round pan, and furthermore, it keeps the contents clean and prevents the chicks from geting into the pan. This base will fit pint quart or half gallon Mason jars and can be used for either feed or water for little chicks. The glass top enables you to see the supply at a glance. Made of heavy Terne Plate metal, one size only.

Diameter $61 / 2$ inches: welght singly, 5 oz.; welght of three, 1 lb.; retall price, 15e each, 2 for 25e: $\$ 1.30$ per dozen.

\section{Don't Let Chicks Drown}

This brooder fountain prevents it. It can be easily cleaned; will not tip over and, should last a lifetime. If wanted by mail, send postage. 1 qt. weighs $1 \frac{1}{4}$ pounds. Price, only 45c.

\section{"Special Wall Fountain}

Lay down to fill-hang up to use. Will stand more rough usage without spilling or damage than any other fountain. It may be cleaned by inserting gravel or sand and shaking. Capacity 1 gallon. Weighs $2 \frac{1}{2}$ pounds. Price, 80c.

\section{Sanitary Water Fountains}

Will not burst when frozen. Removable bottom, easy to fill or clean. A positive necessity to every poultryman. One size only.' The price is only 35c, or six for \$1.75. Capacity, 1 qt. Six weigh 5 lbs. when packed.

\section{Lime Nest Egg}

Made of lime and covered with parafine. Welgh and look like hen's eggs. Practically unbreakable and do not get cold in winter like other eggs. Ereh, 3e; doz., 30e. If sent by mail, add $2 c$ each for postage.

OPAL NEST EGG

Clear white flint nest eggs, will last a llfetime. Each, 3c; doz., 30c, postpaid. 


\section{Save Your Baby Chick Feed}

This little feeder will do it. Well made and sanitary 6 inches in diameter, 8 feeding holes, each, 25c. $8 \frac{1}{4}$ inches in diameter, 12 feeding holes, each, 35c.

\section{Lice Killer Nest Eggs}

Friend of the hen. Our Lice Killing Nest Eggs are almost an exact imitation of the real hen egg, are almost an exact imitation of the real hen egg, and yet contain a powerful disinfectar

Much of the disease among poultry is caused by lice. Save your money and chickens by using our Lice Killing Nest Eggs. They will do it. Try them.

Hens are profitable because of the eggs they produce. But hens will not lay when covered with lice. You can get rid of lice by using Lice Killing Nest Eggs.

It is absolutely lice on poultry longer than can be helped. Confer a blessing on one of your best friends, the hen, by using Lice Killing Nest Eggs.

Positively guaranteed to drive out lice and vermin.

These are packed 12 in a box, each egg wrapped in oiled paper. Price, 6c each; 60c doz. Weight, 2 pounds, not prepaid.

\section{Save the Chicks-Use the Lawn Park Coop}

The wire park pulls out like a bureau drawer and is made from heavy galvanized hardware cloth.

The main coop is made from strong 28-guage galvanized iron. Size of coop: park extended, 18 inches wide, $19 \frac{1 / 2}{2}$ inches high and 48 inches long. When park is closed, coop is 24 inches long.

It gives the chicks sunshine, fresh air, grass and protection from all enemies.

Special prices: Regularly crated, three to crate. Sample coop, $\$ 4.00$ each; three or more, $\$ 3.50$ each. Not prepaid.

\section{0th CENTURY EGG TESTER}

A-very novel practical common sense contrivance for testing eggs either for table purposes or for testing eggs during the period of incubation. A convenient necessity and inexpensve.

Shipping weight, 1 lb. Price, 20c.

If desired by mail, send postage with order.

\section{ANDERSON EGG BOX}

For fancy eggs for hatching. A strong, collapsible box adapted, to shipping fancy eggs. 15eg: size, 20c; 30 -egr size, 35c; 50-egm size, 65c; 100 egg size, \$1.10, not prepaid.

\section{HUDSON MODOC BUCKET SPRAY PUMP}

\section{(For General Purposes)}

Our Modoc has completed its 13 th year of successful operation and over 100,000 are now in active use. It is one of the most effective pumps of its type, absolutely perfect in every respect. The pump is double has large capacity and will give 150 pounds pressure at nozzle. The valves and plunger can be removed for cleaning or inspec tion with a common wrench All parts except handle and foot-rest parts except

\section{SPECIFICATIONS}

Cylinders-1 inch diameter inside, 18 inches long forming the outside tube of the pump. Seamless brass tubing.

Valves-Bronze balls in brass cages

Air Chamber-3/4 inch diameter, 18 inches long, seamless brass tubing, consists of the plunger tube. Ample capacity to give a continuous discharge.

Plunger-3/4 inch diameter, acid-proof cup Foot-Rest-Malleable iron.
Discharge Equipment-3 feet of $1 / 2$-inch spray hose. One Modoc nozzle for spray or solid stream Standard Package-On

No. 122. With Modoc nozzle. Price, each, $\$ \mathbf{8 6 0}$ not prepaid.

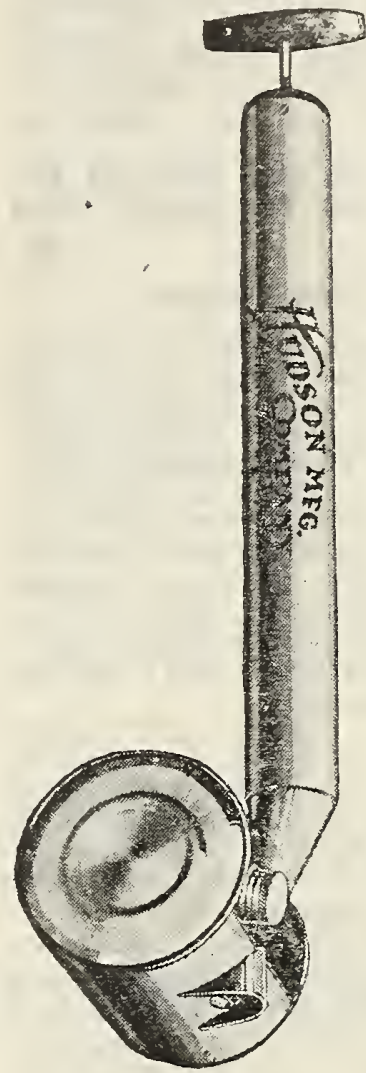

HUDSON MISTY SPRAYER

Our old standby. The best selling quart size sprayer. Made of good stock and carefully tested. The pump passing through the top of the can makes it very strong. By using this construction the air nozzle and spray tube are always in line. Every sprayer a good one and you will have no comebacks. Madie of a good grade of tin and can be furnished on special order with a galvanized or brass tank.

Pump-13/4 inches diam-
eter, 14 inches long. With pointed nose. Hudson plunger leather. Heavy rod.

Tank-4 inches diameter, $41 / 2$ inches long. Lock seamed. no solder. Capacity one full quart. Length over all 21 inches. Shipping weight 16 pounds. Each, Fōe, postpaid.

\section{HUDSON PERFECTION SPRAYER}

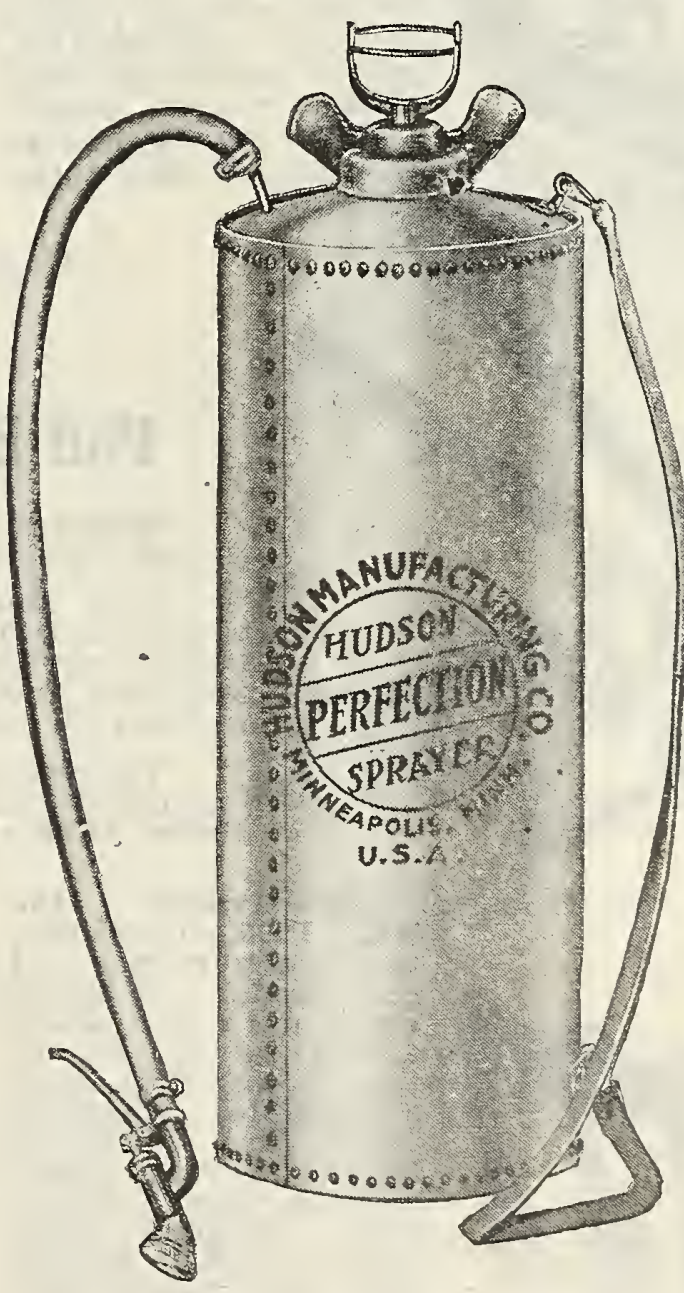

Pump $\rightarrow 13 / 4$ inches d i a m eter, 15 inches brais s tubing. The plunger is The plunger is Hudson special plunger leathers. The valve is brass. We claim great advantage a $\mathrm{n}$. distinction in the design of our top and the handle for the pump, in which we have com bined simplic ity, con ve $n$ lence, strength and service.

The $D$ is charge Hose is attached to the discharge tube which extends to the bottom of the tank and curves to fit the natural bend of the hose. It is more expensive to make, but it eliminates the ugly piece of wire spring so commonly used to keep the hose from

Tank-7 $1 / 2$ inches diameter, 20 inches long; capacity 4 gallons. Made of first quality of galvanized sheets or all-brass as ordered.

Package-One in a heavy carton; shipping weight ten pounds.

No. 110G, Galvanized Tank, price, each, \$7.50, not prepaid. 


\section{LEG BANDS}

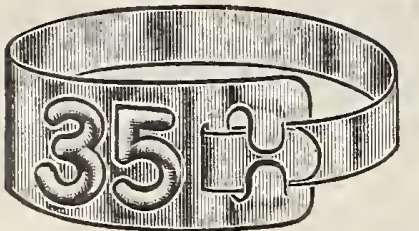

Champion Aluminum Adjustable Leg Bands can be adjusted to fit the leg of any size fowl. It locks with a double clamp, fits the leg perfectly, and, once on, stays until you remove it. They are sold in sets and numbered consecutively. The numbers are always clear and distinct. Trap-nesters and show bird breeders will readily recognize the value of this numbered band.

Prices postpaid, 12 for 20c, 25 for $30 c, 50$ for for $\$ 6.00$.

\section{Celluloid and Aluminum Leg Bands}

H-I Celluloid Spiral Leg Bands provide instant identification for birds without handling as far as you can distinguish color. As easily applied and removed from bird's leg as a key from a key ring. Bands are light and durable in eight bright, fast black, yellow, white and green, in four different Sizes: Nos. 0, 1, 2 and 3. Every poultryman should have on hand at all times a supply of these bands to enable him to mark his birds so he can tell at to clance the toes, months hatched matings, best layers, etc. Be sure to state sizes and colors layers, etc. Be sure to state sizes

Size No. For $\quad$ Doz. $100 \quad 1,000$ Chicks and pigeons........ $\$ .15 \quad \$ .85$ \$ $\$ 7.50$

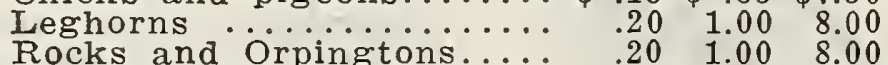
Heavier Breeds, Turkeys,

$20 \quad 1.00 \quad 8.00$ HAMMOND' SLUG SHOT.

* non-poisonous powder and a verv

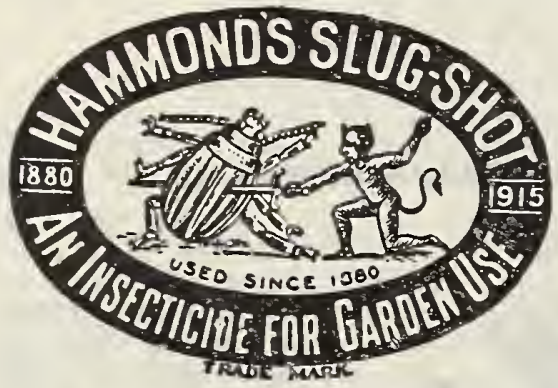
it requires insecticide; mixture or preparation; easily distributed either by duster or in water by spraying. Very effectual in destroying potato b u $\mathrm{s}$ and beetles, green and, black flies, pillars, etc. Price: 1lih. carton, 20e; 5-1b. 70c; 10-1b., \$1.20. Not "repaid.

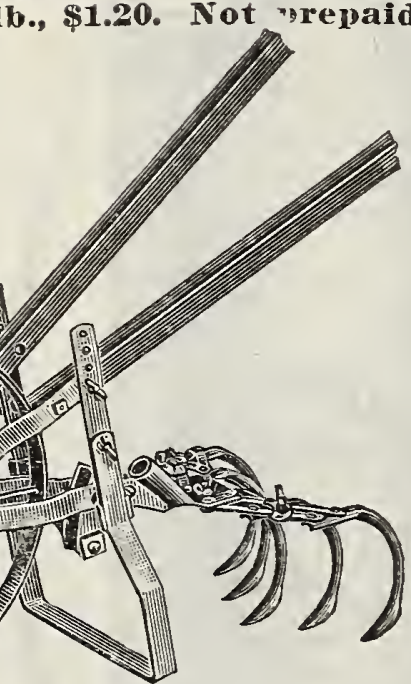

\section{Pull Easy Adjustable Garden Cultivators}

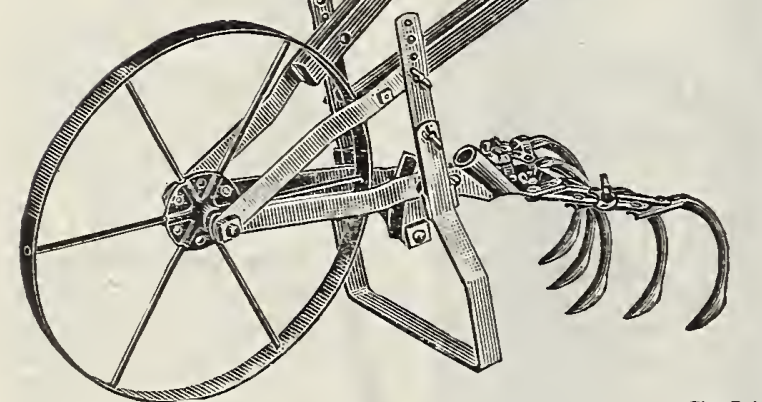

Wheeled Cultivators No. PEW5.-As illustrated with the 5prong, PE5, cultivator, attached.

Also had a keen edged high carbon tool steel wood cutter 9 inches wide. Under most conditions both cultivator and weed cutter can be used at the same time. If the ground is stony or quickly detached, put on a hoe handle and used as a hand tool.

The wheel is 14 inches in diameter-plow style maple handles enameled red with black grips-all steel parts royal blue color. Price, $\$ 4.00$ each. By Parcel Post, 13 pounds.

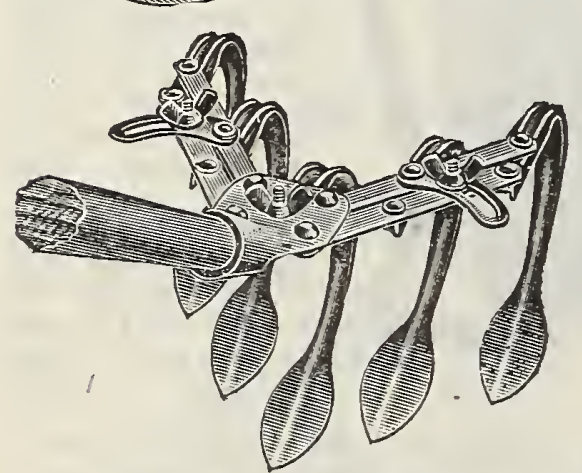

No. Cultivator Hoe the convenience of the popular 5-prong style with the additional advantage of the great Pull-Easy adjustable feature. Teeth are 9 inches long and very broad and strong. These long, grasping teeth will cultivate deeper than any other garthan any

Made for husky work in all kinds of soils-at full width of 12 inches is a first-class rake. Adjustable in width from 6 to 12 inches. Tooth points concaved for perfect scouring. Middle tooth removable.

Four-foot, straight-grained ash handle-weight 2 pounds-packed for Parcel Post shipment, 4 pounds. Price, \$1.25 each.

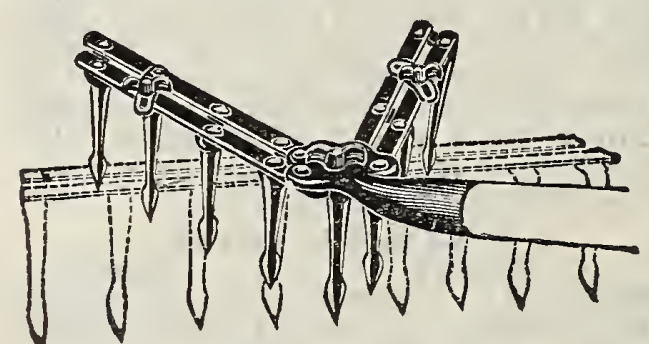

Cultivator rake No, PEC.18 inches is better than an ordinary rake for preparing the seed sturdy, long teeth. When vegetables are small the middle tooth is quickly removed for straddling plants and working two rows at once.

By means of wide-winged thumb nuts at ends of parallel bars, it is secured for cultivating in one stroke at any width of row from 7 to 18 inches wide. The instant adjustability of this cultivator makes it the most popular garden tool manufactured.

Hardwood polished handle, white ash, $4 \frac{1}{2}$ feet long. Weight, 3 pounds. Teeth 3 inches long. Packed in corrugated paper for Parcel Post, shipping 4 pounds. Price, \$1.50 each. 


\section{Lee's Poultry Remedies}

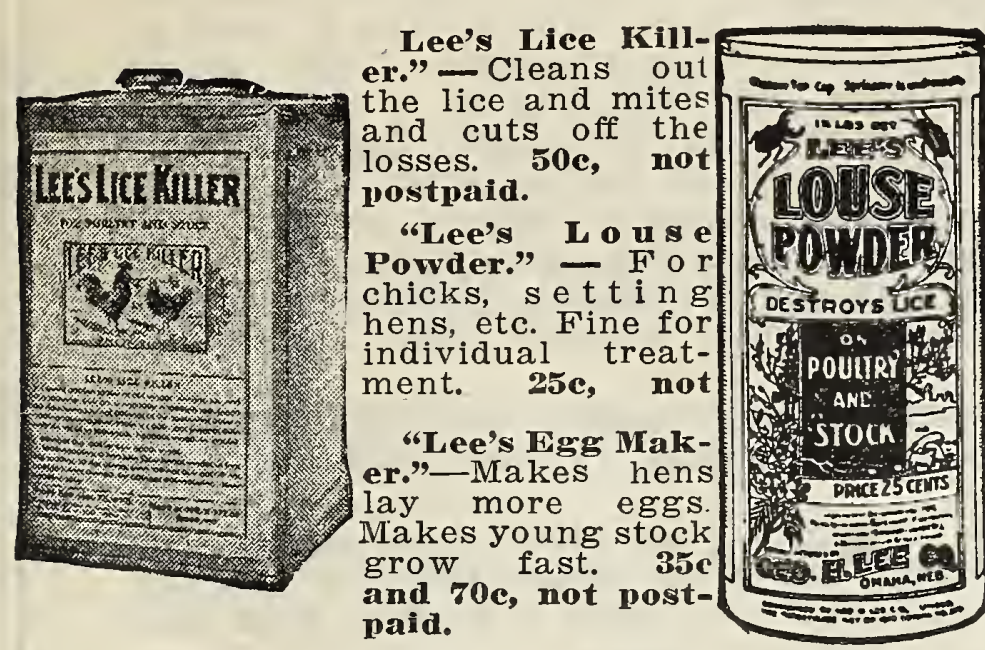

"Lee's Flyo-Curo."-Protects stock from flies and mosquitoes'; sanitary, humane and profitable. $\$ 1.25$, not postpaid.
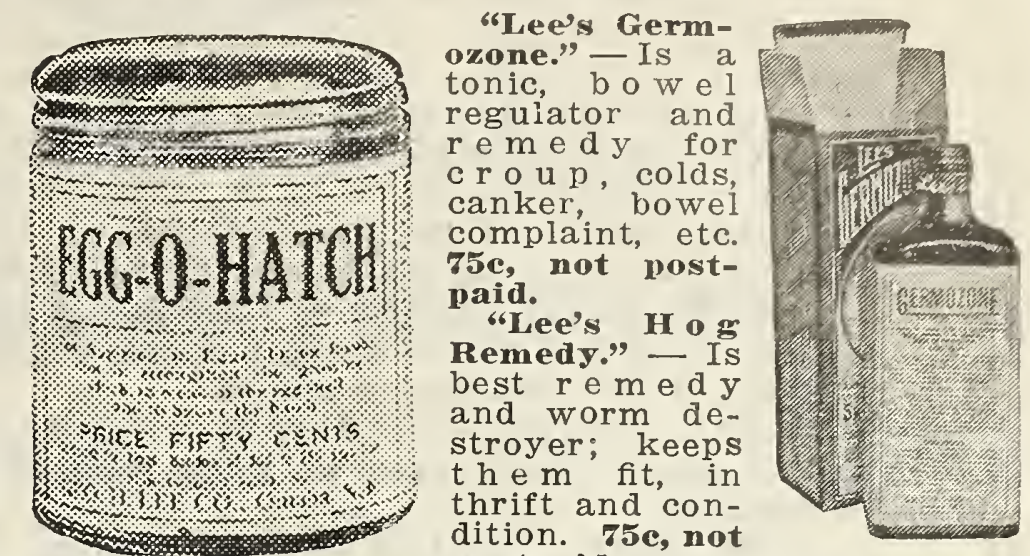

"Egg-O-Hatch."_. postpaid. makes stronger and better chicks. 50c, not postpaid.

"Egg-O-Latum."-Keeps spring and summer eggs perfectly fresh for winter use. 50c, not post-

\section{INGUBATORS}

\section{STOP HATCHING WEAK CHICKS}

with cheap incubators. A Queen costs but little more, and the extra chicks that live and grow soon pay the difference.

Remember, it is not how many chicks you hatch that count, but how many you raise. Chicks that hatch out weak and wobbly, and live but a few days, mean nothing to you but trouble and loss. They make one sick of the poutry busines's.

Most of the chicks you lose in the first few weeks die because they did not have, when hatched, enough strength or vitality for a good start.

\section{QUEEN GHICKS LIVE AND GROW}

Queen Incubators are famous the country over for big hatches of strong, healthy chicks that live and grow. The Queen is accurately regulated, keeping the temperature just right for the hatching chick. No hot and cold changes to weaken the chick's system. The Queen is properly insulated-two layers of wood and one of corrugated straw board, with dead air space. This also helps to maintain an even temperature for the entire hatching
period. Both Queen walls are built of genuine California Redwood,
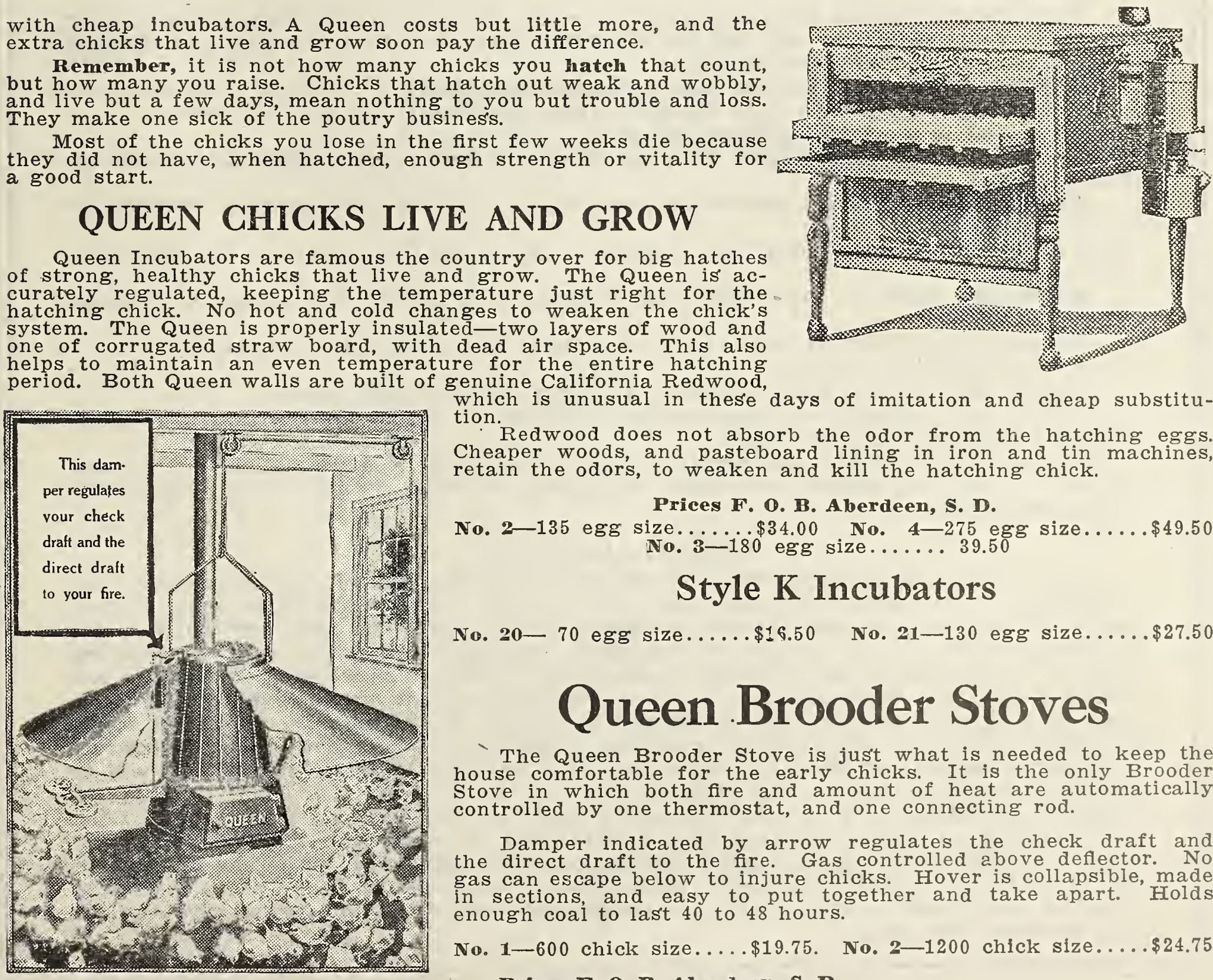

which is unusual in these days of imitation and cheap substitution.

Redwood does not absorb the odor from the hatching eggs Cheaper woods, and pasteboard lining in iron and tin machines, retain the odors, to weaken and kill the hatching chick.

Prices F. O. B. Aberdeen, S. D.

No. 2-135 egg size.....\$34.00 No. 4-275 egg size....\$49.50 No. 3-180 egg size...... 39.50

\section{Style K Incubators}

No. 20-70 egg size....\$16.50 No. 21-130 egg size....\$27.50

\section{Queen Brooder Stoves}

The Queen Brooder Stove is just what is needed to keep the house comfortable for the early chicks. It is the only Brooder Stove in which both fire and amount of heat are automatically controlled by one thermostat, and one connecting rod.

Damper indicated by arrow regulates the check draft and the direct draft to the fire. Gas controlled above deflector. No gas can escape below to injure chicks. Hover is collapsible, made in sections and easy to put together and take apart. Holds enough coal to last 40 to 48 hours.

No. 1-600 chick size....\$19.75. No. 2-1200 chick size...\$24.75

Prices F. O. B. Aberdeen, S. D. 


\section{TERMS AND INSTRUCTIONS FOR ORDERING}

Our terms are cash with each order. Money may be sent at our risk by Draft, Postoffice Money Order, or Registered Letter. We acknowledge freight orders as soon as received, and the same are filled and shipped as promptly as possible. Bill of lading for every freight shipment is mailed when shipment is made. Small orders to go by mail or express are, as a rule, sent out at once without special acknowledgment. Please use order sheet found in catalogue in making out your order, and retain a copy.

We Usually Ship by Freight unless otherwise instructed. We have four railroads here at Aberdeen-C., M. \& St. P., C. \& N. W., Great Northern and M. \& St. L.

Customers Pay Freight or Express on all goods unless they are offered postpaid. We have the American, Wells Fargo, Great Northern and Adams Express companies.

No Charge for Packing or Packages. Everything will be securely packed and labeled and delivered free at the freight depot, express or postoffice, without extra charge for packages unless otherwise stated.

Prepaid Stations. If there is no agent at your railroad station the freight has to be prepaid, and in such cases we must request you to send money with your order to cover the amount.

Order Early. Do this for two reasons. We can give your order more careful and prompt attention if received before we get into the rush of the spring shipping, and second, our assortment is complete early in the season and your order will not be held while we write for permission to substitute for varieties that may be out.

Change of Address. If you have changed or intend to change your address, please let us know, and we will change it on our books, so you will receive our catalog at your new postoffice.

\section{OUR RESPONSIBILITY}

As this catalog will go into the hands of many who have never dealt with us, we kindly ask for a trial order from you, which shall have our best attention. As to our standing, we refer you to the postmaster, Dakota Farmer, or any bank in Aberdeen.

\section{PARCEL POST RATES}

Applicable to seeds, bulbs, plants and merchandise (except poisons, which cannot be sent by mail).

Parcel post rates are fixed according to zones, the greater the distance the higher the rate. Your postmaster will tell you the parcel post zone in which your postoffice is located, measuring from Aberdeen, S. D.

PARCEL POST RATES.-The zone rates are as follows:

First and Second Zone (up to 150 miles from Aberdeen), $5 \mathrm{c}$ for the first

pound and $1 \mathrm{c}$ for each additional pound.

Third Zone (151 to 300 miles from Aberdeen), 6c for the first pound; $2 \mathrm{c}$ for each additional pound.

Fourth Zone (301 to 600 miles from Aberdeen), 7c for the first pound; 4c for each additional pound.

Fifth Zone (601 to 1,000 miles from Aberdeen), 8c for the first pound; 6c for each additional pound.

Sixth Zone (1,001 to 1,400 miles from Aberdeen), 9c for the first pound; $8 \mathrm{c}$ for each additional pound.

Seventh Zone (1,401 to 1,800 miles from Aberdeen), 11c for the first pound;

$10 \mathrm{c}$ for each additional pound.

Eighth Zone (over 1,800 miles from Aberdeen), 12c for each pound.

Parcel post packages must not exceed 70 pounds in weight for the first two zones, and 50 pounds for the other zones.

Parcels of seeds, bulbs, and plants weighing 8 ounces or less are mailable at the rate of $1 \mathrm{c}$ for every two ounces, regardless of distance; if weight is more than 8 ounces the pound rates apply.

\section{SEED WARRANTY}

Most of the failures with seeds are entirely beyond our control and they render it impossible for us to guarantee success, and, therefore, we want it plainly understood that while we exercise great care to have all seeds, plants and bulbs pure and reliable, and also true to name, we do not give any warranty, expressed or implied, as to description, quality, productiveness, or any other matter, of any goods which we send out, and we will not be in any way responsible for the crop. No officer, agent or employee of this company is authorized to make any warranty whatsoever. If the purchaser does not accept the seeds, bulbs or plants on these conditions, notify us at once and we will give instructions for disposition of same, and the money that has been paid for same to us will be promptly refunded. It is to our interest, however, to have everything of the highest quality obtainable, and we would not furnish seeds of doubtful quality for several times the price that we receive for them, as it would injure us more than it would the purchaser. However, we have so much confidence in our seeds that we hereby agree to refill any order for vegetable or flower seeds free of charge. should they prove otherwise than as represented in our catalog. No responsible seed firm can possibly give any further guaranty than this. 


\section{ORDER SHEET}

\section{J. L. LOEBS SEED COMPANY ABERDEEN, SOUTH DAKOTA}

POSTAGE Garden Seeds priced by the packet, ounce, one-fourth pound and pound are postage pald.
Larger quantities apply regular parcel post charges.

Write Name and Address very plainly. Send Money with all Orders. No C. O. D. Shipments.

State Whether by Mail

SEND BX Express or Freight.

NAME

POST OFFICE.

COUNTIY

R. F. D........ Street and No.

STATE

SHIPPING STATION

NAME OF YOUR

EXPRESS CO., or R. $R$

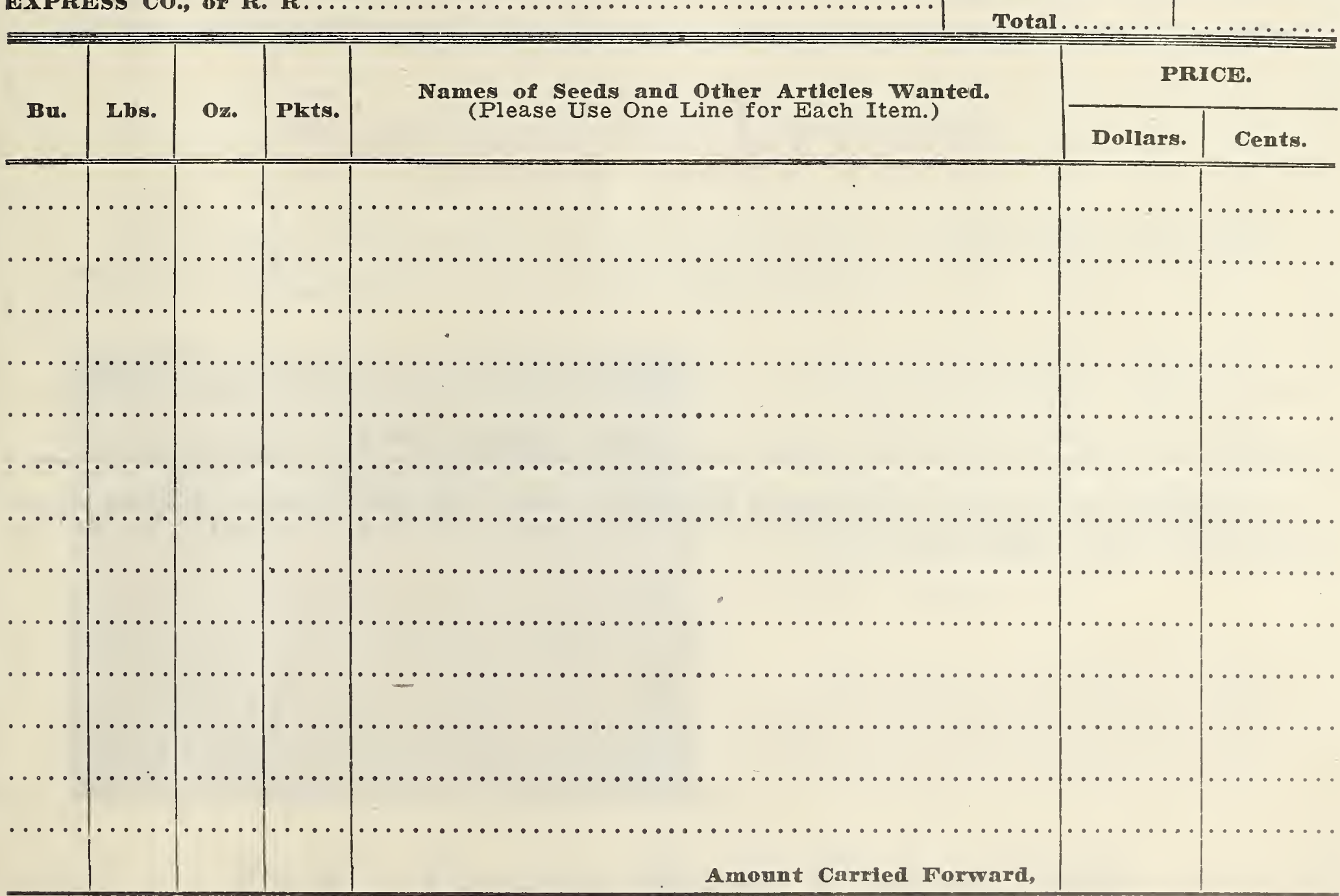

DATE

AMOUNT ENCLOSED.

P. o. Order..... $\$ \ldots \ldots \ldots \ldots$

Draft

Express Order.

Cash

Stamps

Total 


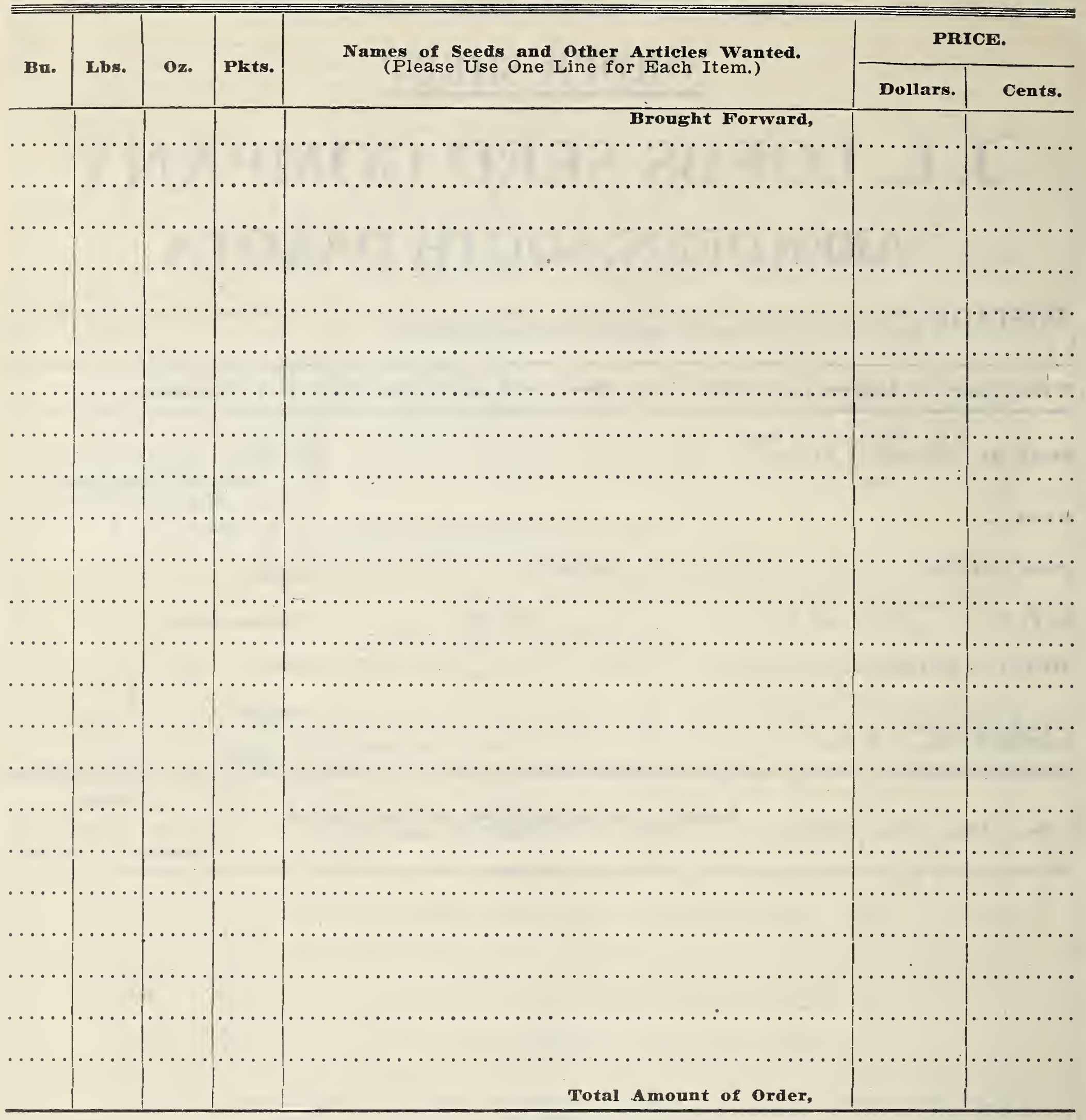

The space below is for remarks about your order. Also please write here the addresses of persons who buy seed or plants and to whom you think our Catalogue would be acceptable. We will remember the favor in filling your order. 


\section{Alfalfa}

No crop is so valuable for the use of dairy farmers and live stock breeders. In feeding value, it ranks higher than red clover or timothy, and once a good crop is established it will last from ten to fifteen years. In the Northwest, alfalfa will produce three good crops of hay each year, yielding from $1 \frac{1 / 2}{2}$ to 3 tons per acre at each cutting. It is the greatest forage plant in the world and is especially adapted to the climatic conditions of this section.

Alfalfa requires well drained land. It is inadvisable to. sow it on land where standing water is present, even for a very short period, or where the land is underlaid with permanent ground waters that are nearer than four feet from the surface. It requires a deep seed bed for the development of its wonderful

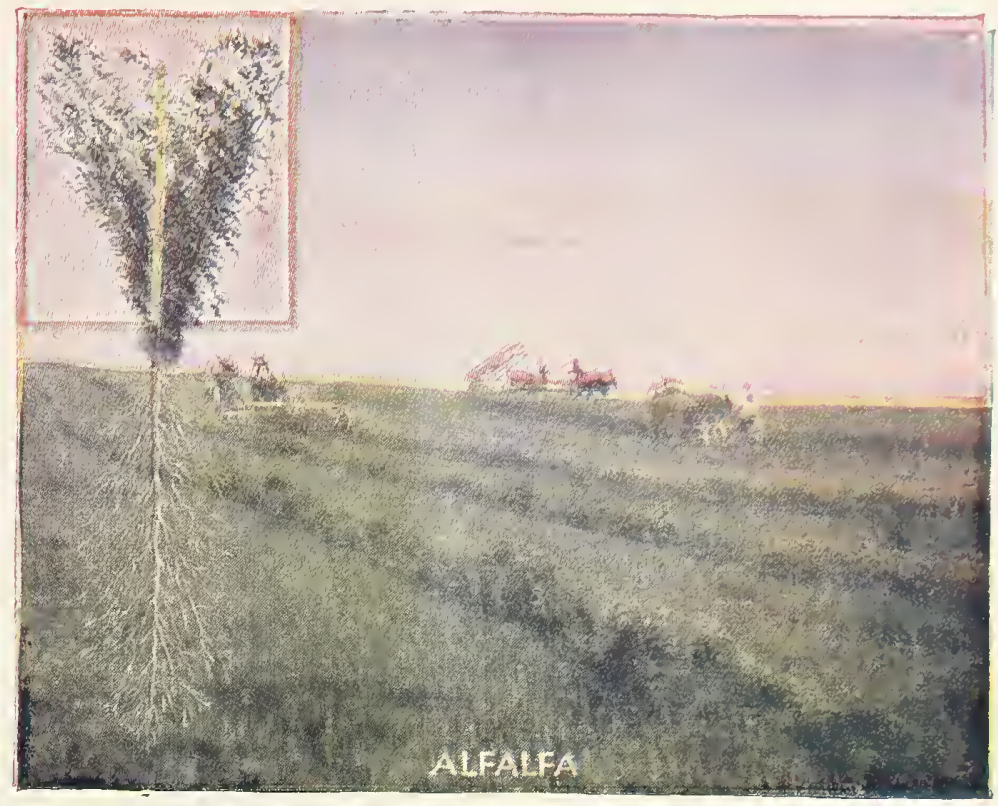
system of roots, therefore, deep plowing is essential to the success of the crop.

Seed may be sown any time during the spring or summer months. For this section we recommend northern grown alfalfa, as it is the hardiest for the extremes of our cold northern climate. It should be cut as soon as new shoots appear at the crowns. Pay no attention to the blossoms. The crop can be cut about once every five weeks during the growing season. After cutting, cure in cocks, and when you cannot wring water from the hay, put into stack or barn at once.

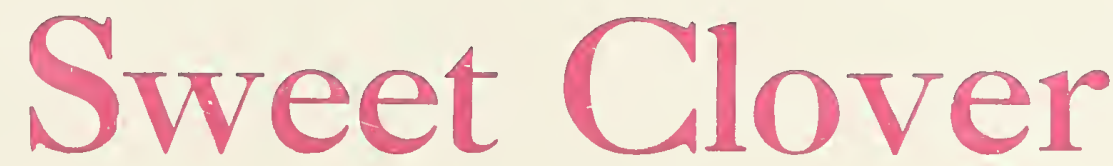

The demand for Sweet Clover is constantly increasing. As a fertilizer, it ranks highest of the leguminous crops; and in many sections it is being used for fodder. Growers claim for it a feeding value equal to that of Red Clover.

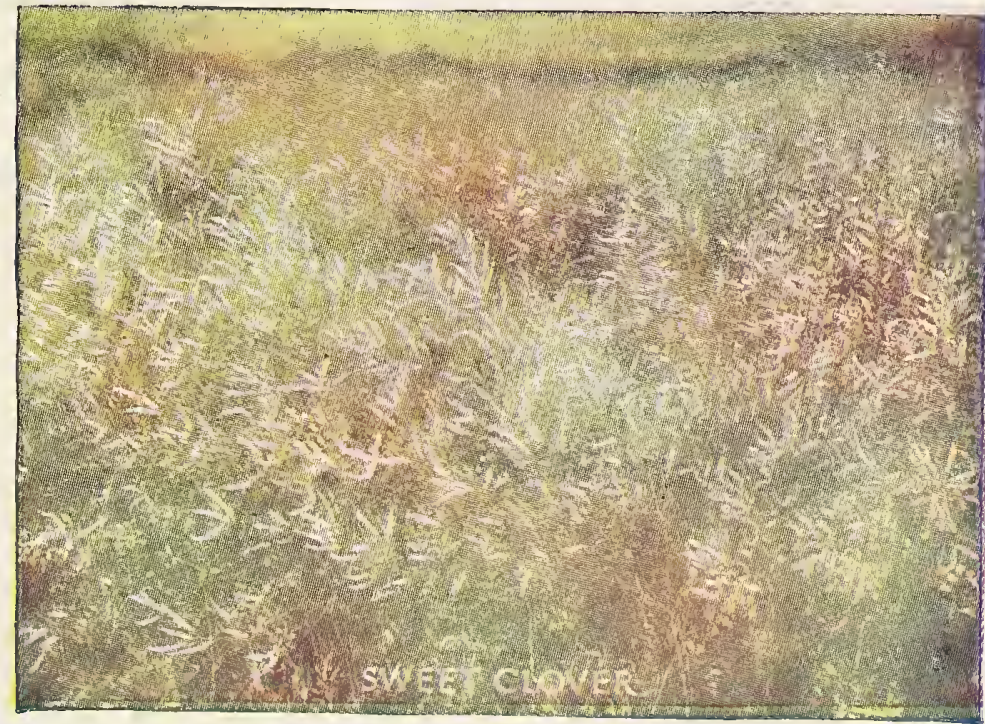

It grows on poor soil, and will in a short time make sandy or rocky soil fertile. It gathers nitrogen from the air and enriches the soil with it. Its strong, fleshy root clusters penetrate deep into the soil and decay when two year's old, leaving their nitrogenous contents in condition for immediate use. This insures enormous yields from the following crops, especially corn.

Sweet Clover is especially adapted for bee pastures, and the bee keeper should not fail to put in at least half an acre. It is greatly relished by the bees, and produces honey as clear as crystal.

\section{J. L. Loebs Seed Company}

\section{Aberdeen}
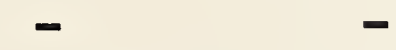

S. Dakota 


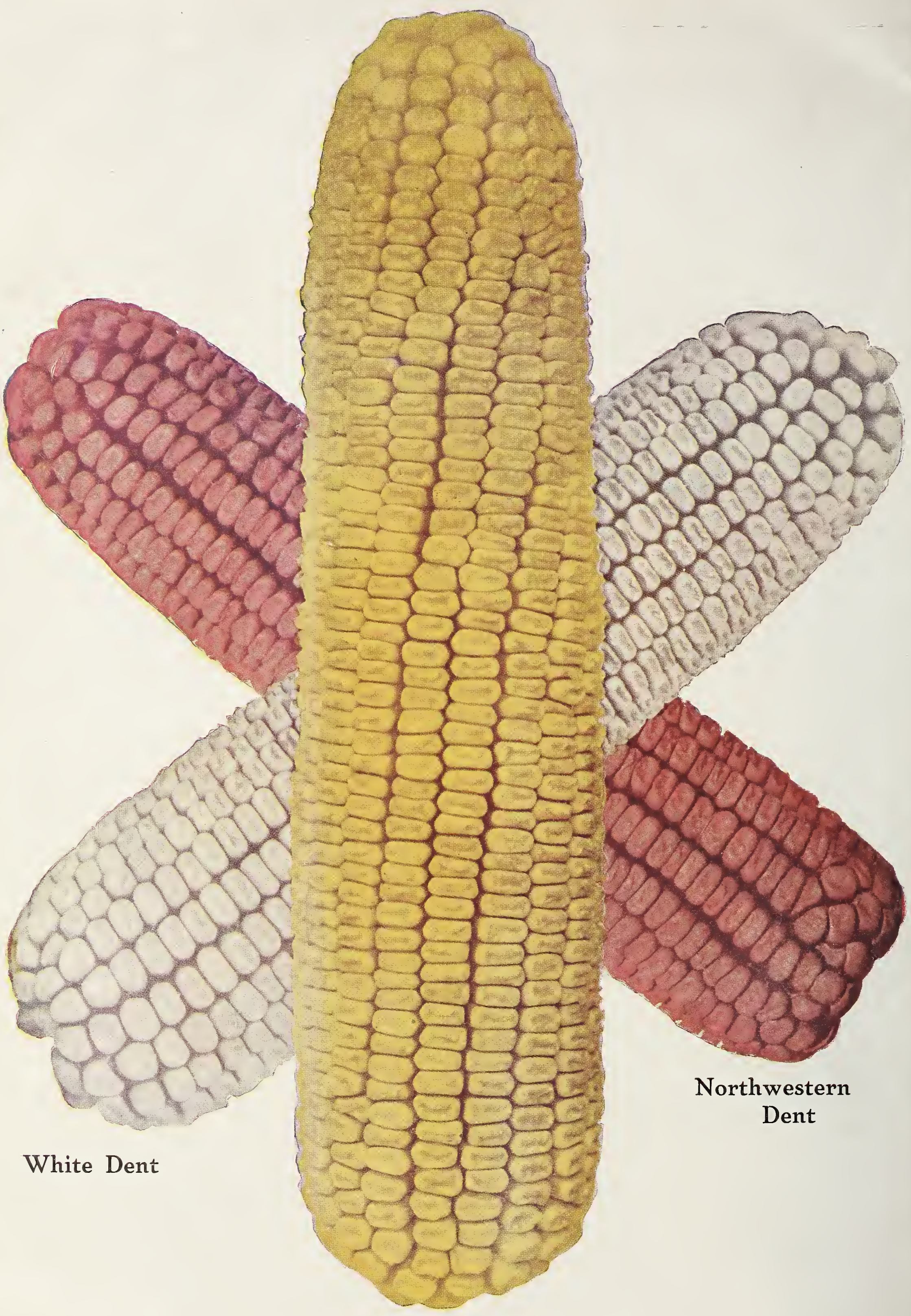

Minnesota No. 13 